Flávio Macêdo Alves

Estudo Taxonômico e Filogenético de Mezilaurus Taub.

(Lauraceae) lato sensu e Restabelecimento de Clinostemon

Kuhlm. \& A. Samp.

São Paulo

2011 
Flávio Macêdo Alves

\section{Estudo Taxonômico e Filogenético de Mezilaurus \\ Taub. (Lauraceae) lato sensu e Restabelecimento de Clinostemon Kuhlm. \& A. Samp.}

Tese apresentada ao Instituto de Biociências da Universidade de São Paulo para a obtenção do Título de Doutor em Ciências, na área de Botânica.

Orientador: Dr. Vinícius Castro Souza

São Paulo

2011 


\section{Ficha Catalográfica}

Alves, Flávio Macêdo
Estudo Taxonômico e Filogenético de Mezilaurus Taub. (Lauraceae) lato sensu com
Restabelecimento de Clinostemon Kuhlm. \& A. Samp. 234p.
Tese (Doutorado) - Instituto de Biociências da Universidade de São Paulo. Departamento
de Botânica
1. Lauraceae, 2. Mezilaurus, 3. Sistemática, 4. Taxonomia
Universidade de São Paulo
Instituto de Biociências
Departamento de Botânica

\section{Comissão Julgadora}

Prof (a). Dr. (a).

Prof (a). Dr. (a).

Prof (a). Dr. (a).

Prof (a). Dr. (a).

Prof. Dr. Vinícius Castro Souza

Orientador 


\section{Agradecimentos}

Agradeço a DEUS, pois sinto Ele sempre ao meu lado,

Ao meu orientador Dr. Vinícius Castro Souza por acreditar em mim e por fazer parte da minha formação,

Ao CNPq pela bolsa de Doutorado no Brasil (141913/2007-0) e Doutorado Sandwich na Inglaterra (201587/2009-2),

Ao programa de pós-graduação em Botânica da Universidade de São Paulo, Instituto de Biociências, São Paulo e seus professores pela minha formação,

Ao Royal Botanic Gardens (Kew) por me permitir visitar a coleção e servir como base para a visita aos outros herbários europeus,

À Dra. Daniela Zappi por me receber tão bem no Kew e abrir as portas da instituição para mim,

À Dra. Ana Paula Savassi Coutinho (Paulinha) pela grande ajuda no trabalho de filogenia molecular, pela paciência, organização, amizade e responder com tanta paciência e carinho todas as minhas dúvidas,

Às professoras Dra. Maria Luiza Salatino e Dra. Deborah Yara Alves Cursino dos Santos por me permitir trabalhar no Laboratório de Fitoquímica e Sistemática Molecular do Departamento de Botânica, Instituto de Biociências, Universidade de São Paulo (USP),

Aos especialistas em Lauraceae, Dr. Henk van der Werff, Dr. Leandro Cézanne de Souza Assis, Dr. João Batista Baitello, Dr. Pedro Luís Rodrigues de Moraes e Msc. Tiago Domingos Mouzinho Barbosa pelas discussões sobre a taxonomia da família,

Ao Msc. Tiago Domingos Mouzinho Barbosa pela ajuda nas coletas em Santa Teresa-ES,

Ao Dr. Hélio Queiroz Boudet Fernandes pelo auxílio com a logística das coletas na Estação Ecológica de Santa Lúcia em Santa Teresa-ES, 
Ao Dr. José Eduardo L. da S. Ribeiro e seus orientados pela ajuda com a logística de coleta na Reserva Ducke em Manaus-AM,

À Laura Lima e ao Marcus pela hospitalidade em Feira de Santana, amizade e companheirismo em Londres,

Ao Pedro Bond Schwartsburd pelas eternas discussões sobre taxonomia e nomenclatura botânica, pela amizade contruída em Londres, companheirismo nas viagens pela Europa, e por me ajudar com os textos em inglês,

Ao Rafael Batista Louzada pela ajuda com a filogenia e momentos agradáveis em Londres e Berlim,

Aos meus amigos do Laboratório de Sistemática Vegetal e Herbário ESA da ESALQ, Gerson Romão, Gabriel Colleta, Juliana Kuntz, Juliana Rando, Dra. Fiorella Mazine, Thiago Flores, Pérsio, Claudia Caliari, Carolina Delfini, Rubens Coelho, Fernando, Carlos, Tiago e Stefânia pelos excelentes momentos de trabalho e amizade,

Ao Dr. Gwilym Lewis pela excelente recepção no Royal Botanic Gardens (Kew) em Londres e ajuda na instituição,

Ao Dr. Jefferson Prado pela ajuda com as discussões sobre nomenclatura botânica,

Ao Dr. Alain Chautems por ter me recebido tão bem em Genebra na Suiça,

Ao Dr. Nicolas Fumeaux, do herbário G-DC, pelas discussões sobre nomenclatura e contribuição para a discussão sobre o protólogo do gênero Mezilaurus,

Ao Dr. Kitajima, Dr. Francisco A. O. Tanaka e Renato pelo auxílio com as fotos da Microscopia Eletrônica de Varredura (MEV) no Laboratório de Microscopia Eletrônica Aplicada (NAP/MEPA) da Escola Superior de Agricultura "Luiz de Queiroz" - ESALQ/USP.

À Mourisa e Paula, técnicas do Laboratório de Fitoquímica e Sistemática Molecular do departamento de Botânica do Instituto de Biociências da Universidade de São Paulo, pela paciência na ajuda com os equipamentos e reagentes do laboratório, 
Ao meu amigo Vitor Junji Suzaki do Laboratório de Fitoquímica e Sistemática Molecular do departamento de Botânica do Instituto de Biociências da Universidade de São Paulo, pela paciência e discussão sobre os protocolos,

A Dra. Renata Udulutsch e Dr. Pedro Dias pelas discussões sobre taxonomia, sistemática e nomenclatura,

Ao Gerson Oliveira Romão, pela amizade e eternas discussões sobre morfologia, taxonomia, sistemática e nomenclatura,

À Carolina Delfini pelo auxílio com a formatação da tese e as pranchas,

Ao Ony, Sr. Victor e Dona Maria pelo grande apoio no Laboratório de Botânica e Herbário ESA da Escola Superior de Agricultura "Luiz de Queiroz" (ESALQ),

Aos meus amigos de república, Lucas Azevedo, Fabrício Terra, Daniel Bini, André Nakatani, Paulo Roger, pelos momentos de amizade e companheirismo,

A toda minha família, em especial minha mãe Rute de Bessa Macedo e meus irmãos, Bruno, Adriano, Gize e Fábio e Marco; meus sobrinhos Marco, Lucas, Kelren, Maria Eduarda e Daniel, À Karina Rébulla Laitart, minha namorada, pelo amor, carinho, companheirismo, amizade, pela ajuda nas correções e principalmente paciência nesse período,

À minha família de Campo Grande-MS, Joel, Alfa, Silvia, Lucas, Lara, Igor; Catarina e Leandro; Wagner, Célia, Andréa e Nádia, por todos os momentos tão felizes na companhia de vocês,

À Carole Bennett Brougham e Christopher Bennett Brougham pela hospedagem, amizade e "aulas do inglês" em Londres,

Ao meu amigo Carlos Rodrigo Lenh, companheiro de todas as horas, e sua esposa Caroline Leuchtenberger por me ajudar com algumas coletas,

Ao meu amigo tailandês Bhanubong (Bawn), pelos grandes momentos de lazer em Londres e Paris, 
Ao Márcio Lara pela confecção das pranchas,

Ao Dr. Milton Groppo pelas dicas com a filogenia,

À dona Nobuko Amano e família pelos bons momentos em São Paulo,

À Tatiana do GaTE lab - Genomics and Transposable Elements Lab, Departamento de Botânica

- IB-USP, pela paciência em receber todas as semanas minhas placas de seqüenciamento e informar sobre as sequências,

Aos meus amigos da Igreja Presbiteriana de Piracicaba, em especial Sérgio, Levi e Esdras, pelos momentos de amizade,

À dona Maria e Sr. Sérgio, pais do meu amigo Sérgio, pela ótima recepção em Belém-PA,

\section{A todos o meu muito obrigado...}


Resumo .01

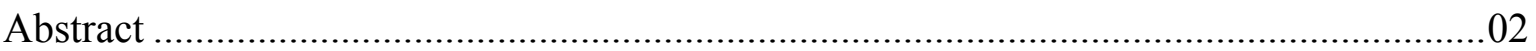

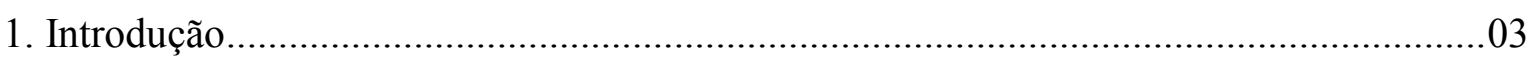

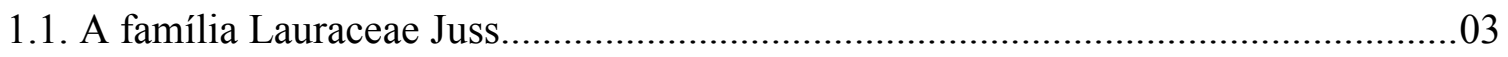

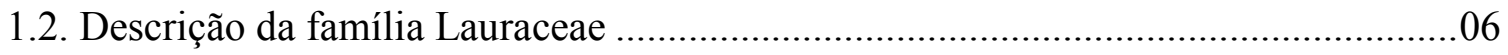

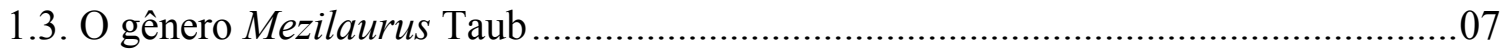

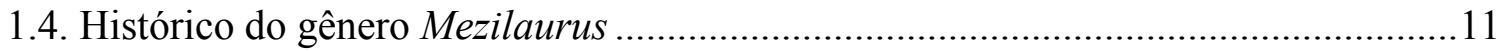

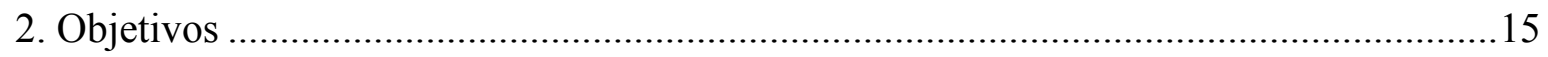

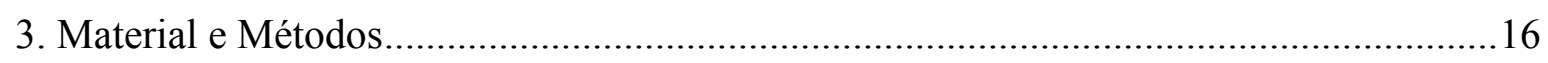

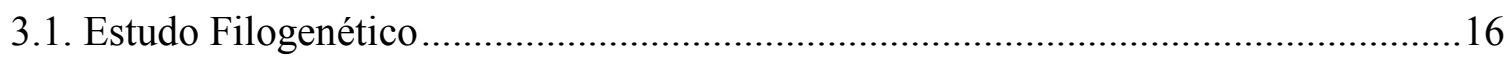

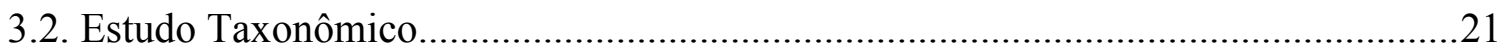

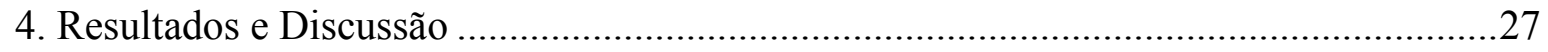

4.1. Relações filogenéticas de Mezilaurus Taub. (Lauraceae) .........................................27

4.2. Revisão taxonômica de Mezilaurus Taub. (Lauraceae) …….......................................55

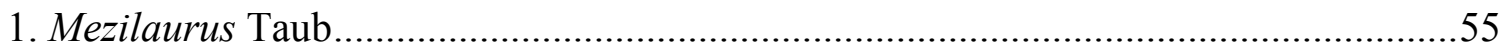

Chave para identificação das espécies de Mezilaurus .....................................................56

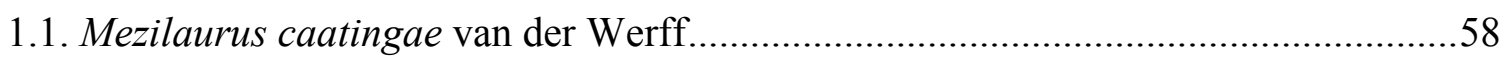

1.2. Mezilaurus crassiramea (Meisn.) Taub. ex Mez.......................................................63

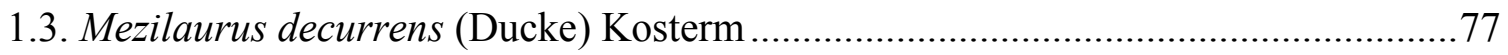

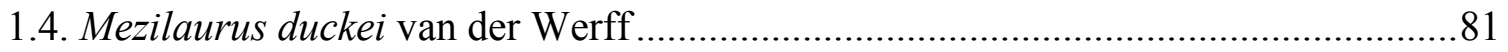

1.5. Mezilaurus glabriantha F.M. Alves \& V. C. Souza, sp. nov. ....................................89

1.6. Mezilaurus introrsa F. M. Alves \& van der Werff, sp. nov. ....................................94

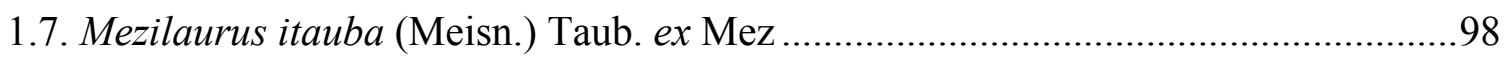

1.8. Mezilaurus microphylla F. M. Alves \& V. C. Souza, sp. nov................................ 119

1.9. Mezilaurus navalium (Allemão) Taub. ex Mez......................................................... 124

1.10. Mezilaurus revolutifolia F. M. Alves \& P. L. R. Moraes, sp. nov.. .......................132

1.11. Mezilaurus sprucei (Meisn.) Taub. ex Mez.............................................................137

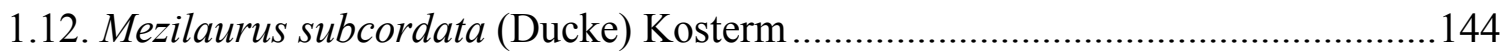

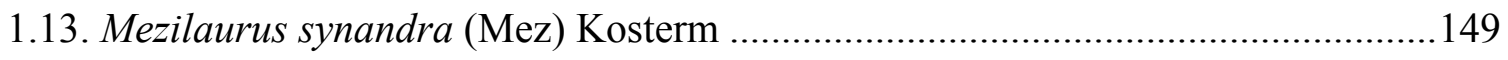

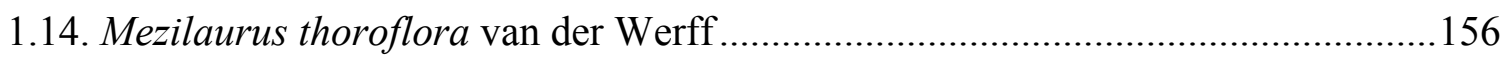

1.15. Mezilaurus vanderwerffii F. M. Alves \& J. B. Baitello ........................................ 160

4.3. Revisão taxonômica de Clinostemon Kuhlm. \& A. Samp. (Lauraceae) ....................166 


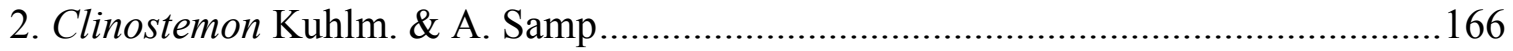

2.1. Clinostemon mahuba (A. Samp.) Kuhlm. \& A. Samp .............................................. 166

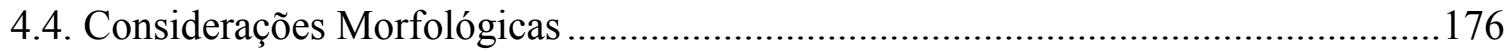

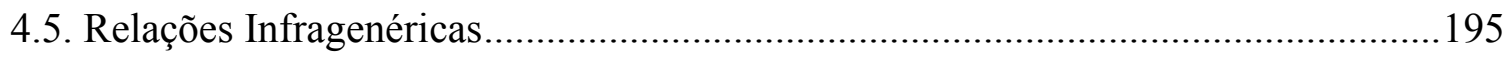

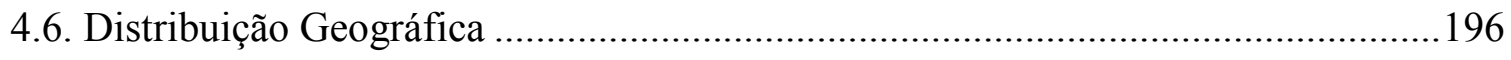

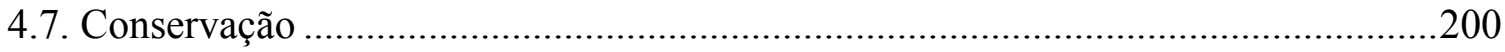

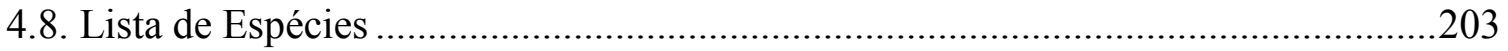

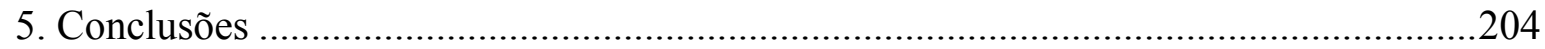

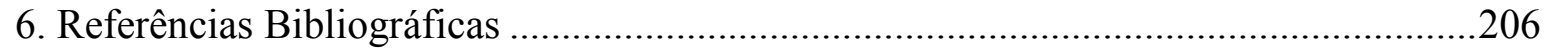

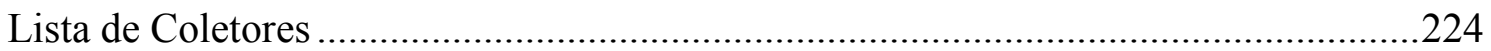

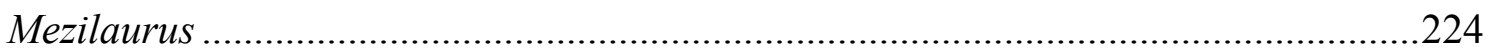

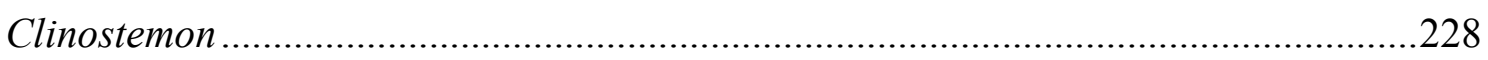

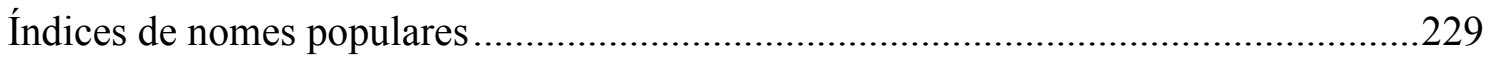

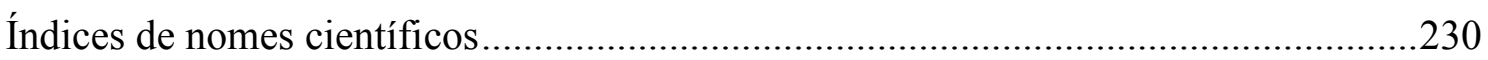


Tabela 1: Espécimes coletados para extração de DNA..................................................... 18

Tabela 2: Marcadores moleculares utilizados nas análises filogenéticas............................. 18

Tabela 3: Espécies com sequências extraídas do GenBank ................................................. 20

Tabela 4: Expedições de campo para coleta.................................................................... 24

Figura 1: Mapa com classificação biogeográfica da América do Sul ................................. 26

Tabela 5: Caracterização das análises filogenéticas......................................................... 27

Figura 2: Cladograma de consenso estrito da análise de Parcimônia baseada em trnH$p s b A$.

Figura 3: Cladograma de consenso de maioria da análise Bayesiana baseada em trnH$p s b A$.

Figura 4: Cladograma de consenso estrito da análise de Parcimônia baseada em ITS ........ 31

Figura 5: Cladograma de consenso de maioria da análise Bayesiana baseada em ITS ........ 32

Figura 6: Cladograma de consenso estrito da análise de Parcimônia baseada nos marcadores moleculares combinados.

Figura 7: Cladograma de consenso de maioria da análise Bayesiana baseada nos marcadores moleculares combinados.

Tabela 6: Características morfológicas dos gêneros do "grupo Mezilaurus"

Figura 8: Cladograma de consenso de maioria da análise Bayesiana baseada nos marcadores moleculares combinados indicando o restabelecimento de Clinostemon ......... 45

Tabela 7: Características morfológicas dos gêneros do clado Mezilauroides....................... 51

Figura 9: Características diagnósticas de Clinostemon e Mezilaurus ................................. 52

Figura 10: Ilustração de Mezilaurus caatingae ................................................................ 61

Figura 11: Mapa de distribuição geográfica de Mezilaurus caatingae, M. crassiramea e

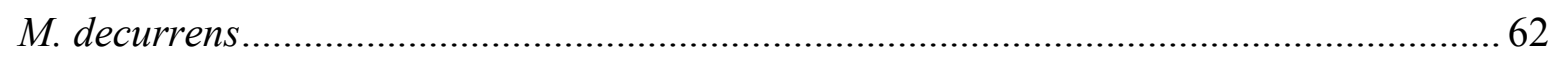

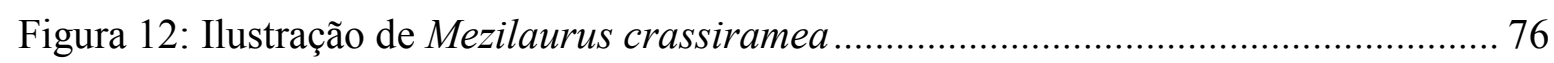

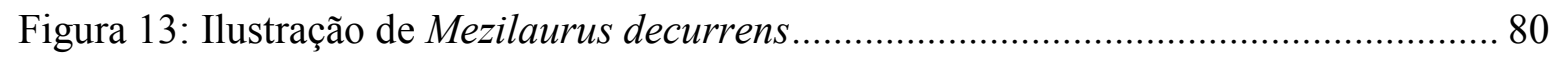

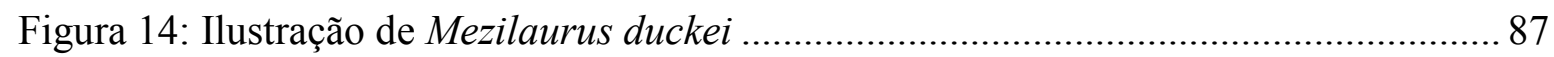

Figura 15: Mapa de distribuição geográfica de Mezilaurus duckei, M. glabriantha e $M$.

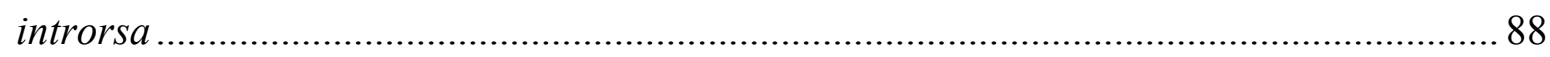

Figura 16: Ilustração de Mezilaurus glabriantha ............................................................. 93

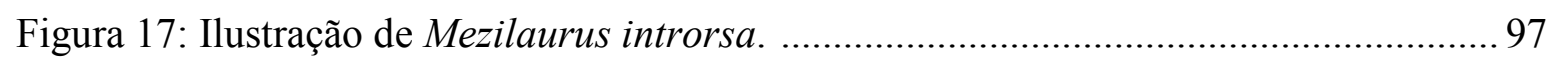


Figura 18: Ilustração de Mezilaurus itauba

Figura 19: Mapa de distribuição geográfica de Mezilaurus itauba.

Figura 20: Ilustração de Mezilaurus microphylla.

Figura 21: Mapa de distribuição geográfica de M. microphylla, M. navalium e $M$. revolutifolia

Figura 22: Ilustração de Mezilaurus navalium .....

Figura 23: Ilustração de Mezilaurus revolutifolia ..... 136

Figura 24: Ilustração de Mezilaurus sprucei 142

Figura 25: Mapa de distribuição geográfica de Mezilaurus sprucei e M. subcordata 143

Figura 26: Ilustração de Mezilaurus subcordata. 148

Figura 27: Ilustração de Mezilaurus synandra 154

Figura 28: Mapa de distribuição geográfica de Mezilaurus synandra, M. thoroflora e $M$. vanderwerrfii. 155

Figura 29: Ilustração de Mezilaurus thoroflora. 159

Figura 30: Ilustração de Mezilaurus vanderwerffii. 164

Figura 31: Ilustração de Clinostemon mahuba. 174

Figura 32: Mapa de distribuição geográfica de Clinostemon mahuba 175

Figura 33: Fotos de árvores e troncos de Mezilaurus. 177

Figura 34: Fotos de troncos de Mezilaurus 178

Figura 35: Fotos de Clinostemon mahuba 179

Figura 36: Fotos de ramos de Mezilaurus. 181

Figura 37: Fotos de Microscopia Eletrônica de Varredura (MEV) do indumento das lâminas foliares de Clinostemon e Mezilaurus...... 183

Figura 38: Inflorescências de Mezilaurus. 186

Figura 39: Fotos de Microscopia Eletrônica de Varredura (MEV) de flores de Clinostemon e Mezilaurus. 188

Figura 40: Fotos de Microscopia Eletrônica de Varredura (MEV) de flores e pedicelos de Mezilaurus.

Figura 41: Fotos de Microscopia Eletrônica de Varredura (MEV) de estames de Clinostemon e Mezilaurus.

Figura 42: Fotos de frutos de Mezilaurus. 194

Figura 43: Mapa de distribuição geográfica do gênero Mezilaurus..... 197 


\section{Resumo}

Este trabalho teve como objetivo testar o monofiletismo de Mezilaurus e a relação deste com os gêneros do "grupo Mezilaurus" (sensu Rohwer \& Rudolph 2005), incluindo um número maior de táxons do que os tratamentos anteriores, além de revisar os limites morfológicos entre as espécies deste gênero. O "grupo Mezilaurus" (sensu Rohwer \& Rudolph 2005), emergiu em filogenias prévias como monofilético, composto pelos gêneros Anaueria, Chlorocardium, Mezilaurus, Sextonia e Williamodendron. O trabalho baseou-se em sequências dos marcadores moleculares trnH-psbA e ITS de nove espécies de Mezilaurus e 15 espécies de grupos-externos. Análises de Parcimônia e Bayesiana foram empregadas com os marcadores separadamente e combinados. Os resultados obtidos demonstraram o "grupo Mezilaurus" como não monofilético e posicionamento incerto de Chlorocardium e Anaueria. Os Mezilauroides (sensu Rohwer \& Rudolph 2005), com Mezilaurus, Sextonia e Williamodendron emergiu como monofilético, entretanto, o gênero Mezilaurus, atualmente circunscrito, não é monofilético e, uma de suas espécies, M. mahuba, surgiu como grupo-irmão de Sextonia. Por essa razão, a espécie foi removida de Mezilaurus e restabelecida como Clinostemon. Com base nessa nova circunscrição, foram realizadas as revisões taxonômicas de Mezilaurus e Clinostemon, baseadas em coleta de material botânico em expedições de campo e análises de aproximadamente 550 espécimes de exsicatas, oriundas de cerca de 60 herbários. Mezilaurus (15 espécies) e Clinostemon (1 espécie) compartilham folhas congestas no ápice dos ramos, produto de seu crescimento rítmico apositivo, flores bissexuadas, três estames férteis, representando a terceira série do androceu, anteras biloceladas e fruto com cúpula de pateliforme a plana com tépalas persistentes. Clinostemon, entretanto, apresenta anteras encurvadas e um par de glândulas nos filetes. Foram realizadas sinonimizações, lectotipificações e a descrições de quatro novas espécies de Mezilaurus para a ciência, elaboradas chaves de identificação, descrições morfológicas, além de comentários taxonômicos, fenológicos e de conservação e disponibilizadas ilustrações das espécies dos dois gêneros. 


\begin{abstract}
This study aimed to test the monophyletism of Mezilaurus and its relation within the "Mezilaurus group" clade (sensu Rohwer \& Rudolph 2005), including more taxa than the previous treatments, and to revise the morphological boundaries between the species of the genus. The "Mezilaurus group" had emerged as monophyletic in previous phylogenies, with Anaueria, Chlorocardium, Mezilaurus, Sextonia, and Williamodendron. The work was based in the molecular markers trnHpsbA and ITS of nine Mezilaurus species, and 15 species from the outgroup. Parsimony and Bayesian analysis were performed with the markers both separately and combined. The results demonstrate that the "Mezilaurus group" is not monophyletic and uncertain position of Chlorocardium and Anaueria. The Mezilauroids, containing Mezilaurus, Sextonia, and Williamodendron, arose as monophyletic, although the Mezilaurus genus, as currently defined, is not monophyletic and M. mahuba emerged as sister of Sextonia. Therefore, it was necessary to remove M. mahuba of its circumscription, and reinstate this species as Clinostemon. Based on this circunscription, were carried out the taxonomic revisions of Mezilaurus and Clinostemon, based on collecting botanical specimens in expeditions, and analisys of 550 specimens of exsiccates from about 60 herbaria. Mezilaurus (15 species) and Clinostemon (1 species) have rythmic branching with distally clustered leaves, bisexual flowers, three fertile stamens, representing the third androecial whorl, 2-locular anthers, fruit with a minute discoid cupule, and persistent tepals. However, Clinostemon has recurved anters and one par of glands at the base of filaments. Synonymizations, lectotypifications, description of four new species of Mezilaurus to science, keys, morphologic descriptions, fenological aspects and conservation, taxonomic commentaries and ilustrations are presented for the two genera.
\end{abstract}




\section{Introdução}

\subsection{A família Lauraceae Juss.}

Lauraceae é uma família pantropical, constituída por árvores e arbustos, com a exceção do gênero Cassytha L., com espécies herbáceas parasitas. Representada por 52 gêneros e cerca de 3000 espécies (Rohwer 1993a), a família está bem diversificada no sudeste da Ásia, Madagascar, norte da América do Sul e costa leste do Brasil (Rohwer 1993a, b; Madriñán 2004a). No Brasil ocorrem 23 gêneros e cerca de 420 espécies de Lauraceae (Quinet et al. 2010), com alta diversidade nas florestas pluviais, restingas e no Cerrado (G. M. Barroso et al. 2002; Souza \& Lorenzi 2008).

A família é a mais rica entre as Angiospermas Magnoliídeas (Judd et al. 2009) e está, em termos florísticos, entre as que mais contribuem para a riqueza da flora nos neotrópicos (Gentry 1988; Burger 1988; van der Werff 1991) podendo ser a principal família em altitudes intermediárias dos Andes (Gentry 1988) e em florestas do sudeste asiático (Whitmore \& Sidiyasa 1986).

Lauraceae possui relevante importância econômica e esse potencial é conhecido desde 2800 a.C. na China com a utilização do óleo de Cinnamomum camphora (L.) J. Presl na medicina (Kostermans 1952a). Espécies como o abacate (Persea americana Mill.), a canela (Cinnamomum zeylanicum Blume) e o louro (Laurus nobilis L.) são utilizadas em todo o mundo na alimentação. Substâncias aromáticas são extraídas de algumas espécies, como o pau-rosa (Aniba rosaeodora Ducke); a madeira de algumas espécies como a imbuia (Ocotea porosa (Vell.) Rohwer), o sassafrás (Ocotea odorifera (Nees) Barroso), a itaúba (Mezilaurus itauba (Meisn.) Taub. ex Mez) e de outros gêneros é amplamente explorada em diversas regiões devido a sua alta durabilidade e resistência (Vicentini et al. 1999; Souza \& Lorenzi 2008). 
Entretanto, a identificação de suas espécies é tarefa difícil (van der Werff 1991; Baitello 2001) e Lauraceae está entre as famílias mais citadas sem identificação específica em estudos florísticos (Caiafa \& Martins 2007; Thomaz \& Monteiro 1997). Entre as Lauraceae neotropicais é comum encontrar, por exemplo, duas espécies com morfologia vegetativa idêntica, consideradas como uma mesma espécie, mas diferindo profundamente nas características florais e do fruto, e pertencendo a gêneros diferentes (Burger 1988). Por essa razão, espécies da família não podem ser distinguidas seguramente baseando-se apenas em caracteres vegetativos e para uma boa identificação é essencial a presença de flores (Rohwer 1993b), uma vez que chaves de identificação e estudos taxonômicos de Lauraceae estão pautados em caracteres florais (van der Werff 1991; Burger 1988).

Lauraceae apresenta um longo histórico na literatura botânica (Kostermans 1952a, b, c). A primeira espécie, pertencente ao gênero Laurus L., foi aceita por Linnaeus em 1753, enquanto o primeiro monografista da família foi Nees (1836). Meissner (1864) realizou um dos mais importantes estudos em Lauraceae e, juntamente com Nees (1836), estabeleceu as bases para classificação da família. Entre os trabalhos clássicos realizados com Lauraceae destacam-se também os de Meissner (1866), Bentham \& Hooker (1880), Pax (1889) e Mez (1889).

Historicamente, Cassytha foi colocada à parte dentro da família, geralmente na subfamília Cassythoideae, tendo como base numerosas especializações relativas ao seu hábito trepador e parasita, enquanto os outros gêneros, com espécies arbóreas ou arbustivas, são agrupados na heterogênea subfamília Lauroideae. As principais características utilizadas pelos autores em classificações foram a presença ou ausência de envólucro na inflorescência, flores uni ou bissexuadas, número de estames férteis e locelos por antera e proporção de cobertura da cúpula no fruto (Nees 1836; Meissner 1864; Bentham \& Hooker 1880; Pax 1889; Mez 1889).

Mais recentemente, Kostermans (1936a, b, 1937, 1938a, b, c, 1953), realizou diversos trabalhos com a finalidade de classificar Lauraceae (Kostermans 1957). Contribuições 
importantes foram feitas também por Allen (1945, 1966), Bernardi (1962), Hutchinson (1964), Richter (1981), van der Werff (1991), Rohwer \& Kubitzki (1985), Rohwer (1986, 1993a, b), Rohwer et al. (1991) e van der Werff \& Richter (1996).

No Brasil, os primeiros autores a trabalhar com Lauraceae foram Meissner (1866) para a Flora Brasiliensis, Sampaio (1917) com espécies do Mato Grosso e L. J. Barroso (1949), que publicou uma chave de identificação para os gêneros nativos e exóticos do Brasil. Destacam-se também os trabalhos com biogeografia, floras regionais e envolvendo alguns gêneros de Vattimo-Gil (1956a, b, 1957, 1958, 1959, 1966a, b, 1976, 1978a, b, 1979a, b, c, 1980a, b), CoeTeixeira (1963, 1965, 1975, 1980), Pedralli (1984, 1986, 1987) e Baitello \& Coe-Teixeira (1987); mais recentemente, os de Vicentini et al. (1999), Quinet \& Andreata (2002), Baitello et al. (2003), Assis et al. (2005), Moraes (2005, 2006) e Quinet (2005); e as listagens da Flora da Mata Atlântica de Quinet (2009) e da Flora do Brasil por Quinet et al. (2010).

Com relação a filogenia molecular, Renner (1999) foi a primeira autora a realizar um trabalho mais amplo para testar o monofiletismo de Lauraceae. A autora utilizou sequências de $r b c L$ e de seis outros marcadores plastidiais, evidenciou o monofiletismo de Lauraceae.

Rohwer (2000) foi o primeiro a estudar as relações sistemáticas dentro da família baseadas em sequências de marcadores moleculares, nesse caso o matK. O autor demonstrou que inúmeras características tradicionalmente utilizadas na taxonomia da família não eram suportadas por seus dados moleculares.

Chanderbali et al. (2001) realizaram um trabalho mais amplo, com maior número de terminais de Lauraceae e baseados em quatro marcadores plastidiais e um nuclear. Segundo os autores, alguns grupos tradicionalmente reconhecidos foram suportados pelas análises moleculares. Entre eles estão Cryptocaryeae sensu van der Werff \& Richter (1996), Laureae de Kostermans (1957), van der Werff \& Richter (1996) e Rohwer (1993a) e Cinnamomeae de Kostermans (1957). 
Já Rohwer \& Rudolph (2005), utilizaram sequências de trnK em inferências filogenéticas dentro da família. Os autores demonstraram que classificações, cuja ênfase foi demasiada no número de locelos e de estames férteis, produziram agrupamentos genéricos artificiais. Outros trabalhos com filogenia molecular em determinados táxons de Lauraceae foram os de Endlicheria (Chanderbali 2004), Laureae (Li et al. 2004), Litsea Lam. (Li et al. 2008) Persea Mill. (Rohwer et al. 2009) e Neocinnamomum H. Liu (Wang et al. 2010).

Uma das principais conclusões dos autores foi que em Lauraceae, a presença de anteras com 2 ou 4 locelos tem evoluído paralelamente em táxons não próximos filogeneticamente (Rohwer 2000; Chanderbali et al. 2001; Rohwer \& Rudolph 2005). Por essa razão, gêneros próximos filogeneticamente, tais como Sextonia van der Werff, Williamodendron Kubitzki \& H.G. Richt. e Chlorocardium Rohwer, H.G. Richt. \& van der Werff (anteras tetraloceladas), Anaueria Kosterm. e Mezilaurus Taub. (anteras biloceladas), nunca foram considerados próximos por classificações baseadas apenas em caracteres morfológicos (Chanderbali et al. 2001).

\subsection{Descrição da Família Lauraceae}

Baseada em Meissner (1866), Mez (1889), Kostermans (1957), Vattimo-Gil (1966), Rohwer (1993a), G. M. Barroso et al. (2002), Quinet \& Andreata (2002), Baitello et al. (2003), Madriñán (2004a) e van der Werff (1991).

Lauraceae Juss., Gen. P1. 80. 1789. nom. cons.

Árvores ou arbustos, monoicos, dioicos ou gimnodioicos, raro trepadeira parasita (Cassytha). Folhas alternas, raro opostas à subopostas (Beilschmiedia Nees) ou subverticiladas; estípulas ausentes. Inflorescências axilares ou subterminais, tirsoides, tirsoide-paniculadas, 
racemiformes, pseudo-umbeladas, raramente capituladas ou reduzida a uma única flor. Flores monoclinas ou diclinas, em geral 3-meras, actinomorfas, 6 ou 9 tépalas (Phyllostemonodaphne) distribuídas em dois verticilos, iguais a subiguais ou desiguais com as externas menores que as internas (Persea), caducas ou persistentes até na cúpula. Androceu com 3, 6 ou mais comumente 9 estames férteis, raramente acima disso, dispostos em 4 séries (I, II, III, IV); anteras valvares, biloceladas ou tetraloceladas. As séries de estames estão dispostas em direção ao centro da flor, sendo a série I oposta as tépalas externas, série II em frente as tépalas internas, série III mais internamente e oposta aos estames da série I e série IV oposta e mais internamente a série II; séries I e II geralmente férteis com anteras introrsas, série III geralmente com um par de glândulas na base dos filetes, série IV geralmente estaminodial. Gineceu com ovário súpero ou raramente ínfero (Hypodaphnis Stapf), unicarpelar, unilocular, uniovulado, placentação pêndula. Fruto baga monospérmica, geralmente envolvido na base pela parede do hipanto modificado em cúpula ou totalmente envolvido pela parede do hipanto em uma núcula (Cryptocarya $\mathrm{R}$. Br.); cúpula com margem simples ou dupla. Sementes adultas sem endosperma, embrião desenvolvido e cotilédones carnosos.

\subsection{O gênero Mezilaurus Taub.}

Mezilaurus Taub. é um gênero de Lauraceae arbóreo ou arbustivo, reconhecido com cerca de 18 espécies e distribuição exclusiva na região tropical da América do Sul. A maioria de suas espécies ocorre na região amazônica, entre os paralelos do Equador e o de Capricórnio, podendo ser encontradas desde a Colômbia, Venezuela, Equador, Peru, Bolívia, Suriname, Guiana, Guiana Francesa até o sudeste do Brasil (van der Werff 1987). 
A maioria das espécies do gênero são conhecidas popularmente como "itaúba" ou “tapinhoã” e sua madeira tradicionalmente tem sido empregada na construção naval, fabricação de móveis e de todos os tipos de construções duráveis (Record \& Hess 1942; Lisboa et al. 1991).

Mezilaurus pode ser distinguido dentro de Lauraceae pela combinação dos seguintes caracteres: folhas congestas no ápice dos ramos, em decorrência de seu crescimento rítmico apositivo, inflorescências do tipo duplo racemo (dibótrio), flores bissexuadas, três estames férteis - representando a série III do androceu - anteras biloceladas, eretas, ausência de glândulas nas flores e cúpula de pateliforme a plana com tépalas persistentes.

Meissner (1864) agrupou Mezilaurus (como Silvaea) na tribo Cryptocaryeae, utilizando o tipo de inflorescência, flores uni ou bissexuadas, número de estames férteis e cobertura da cúpula no fruto como principais critérios para a classificação de Lauraceae. Entre os gêneros próximos a Mezilaurus, o autor relacionou Acrodiclidium Nees \& Mart. e Misanteca Schltdl. \& Cham. (sinônimos de Licaria Aubl.), seis estaminódios externos e fruto incluso na cúpula.

Bentham \& Hooker (1880) transferiram espécies de Mezilaurus (como Silvia e Acrodiclidium) para Endiandra R. Br. e Misanteca, respectivamente, alocando o grupo na tribo Perseaceae. Os autores utilizaram a presença de dois locelos, estames férteis da série III do androceu extrorsos e livres para definir a tribo. Bentham \& Hooker (1880) relataram proximidade entre os gêneros Acrodiclidium, Misanteca e Endiandra.

Pax (1889) utilizou, no entanto, como primeiro critério para classificar Lauraceae o número de locelos seguido do número de estames férteis. Por essa razão, o autor agregou Mezilaurus (como Silvia) na tribo Acrodiclidieae, juntamente com Endiandra, Acrodiclidium e Misanteca.

Mez (1889) ressaltou as inflorescências, número de locelos, série IV do androceu com estames férteis ou estaminodios e flores uni ou bissexuadas. Mezilaurus (como Silvia) foi 
incorporado na tribo Perseeae e entre outros gêneros, juntamente com Acrodiclidium e Misanteca (sinônimos de Licaria).

Kuhlmann \& Sampaio (1928) criaram o gênero Clinostemon Kuhlm. \& A. Samp., baseado em Acrodiclidium mahuba A. Samp. Segundo os autores, o novo gênero seria próximo de Mezilaurus (Silvia), diferenciando-se pela presença em Clinostemon de estames encurvados, um par de glândulas nos filetes e nove estaminódios, representando as séries I, II e IV do androceu.

Kostermans (1957) deu mais ênfase ao tipo de inflorescência associada a proporção do envolvimento do fruto pela cúpula para classificar Lauraceae. O autor agrupou Mezilaurus na tribo Perseeae e, por possuir dois locelos, na subtribo Beilschmiediineae, juntamente com Appolonias Nees, Dahaasia Blume, Beilschmiedia, Endiandra, Hexapora Hook. f. e Potomeia Thouars. Segundo o autor, Mezilaurus possui características florais tais como as de Endiandra, porém, com deiscência das anteras lateral e folhas fasciculadas. Licaria, que sempre ocorreu em classificações anteriores na mesma tribo que Mezilaurus, em Kostermans (1957) foi agrupada na tribo Cinnamomeae, por possuir cúpula cupuliforme e na tribo Anibineae por conter dois locelos.

Hutchinson (1964) voltou a destacar as inflorescências, o número de locelos e posteriormente o fruto total ou parcialmente envolvido pela cúpula. $\mathrm{O}$ autor classificou Mezilaurus na tribo Appollonieae, juntamente com os gêneros Endiandra, Licaria e Misanteca (sinônimo de Licaria).

Richter (1981) propôs uma classificação de Lauraceae, baseada na anatomia da madeira e da casca, destacando Mezilaurus próximo de Anaueria Kosterm. e Clinostemon. Segundo o autor, a anatomia de Mezilaurus é indistinguível ou bastante similar a de Clinostemon, porém, não possuindo paralelo com Licaria ou Endiandra.

Van der Werff (1987) aumentou a circunscrição de Mezilaurus, incluindo Clinostemon e duas espécies com quatro locelos no gênero. O autor definiu Mezilaurus com árvores ou arbustos, 
folhas usualmente congestas no ápice dos ramos, flores bissexuadas, três estames férteis, dois locelos (quatro locelos em duas espécies), estaminódios presentes ou ausentes e glândulas ausentes (presente em uma espécie) e fruto com cúpula pequena e pateliforme. No mesmo ano, Kubitzki \& Richter (1987) criaram o novo gênero Williamodendron, transferindo para este, espécies com quatro locelos que van der Werff (1987) havia descrita como Mezilaurus.

Rohwer (1993a) ressaltou, em sua classificação de Lauraceae, a inflorescência associada com a posição dos locelos. O autor agrupou Mezilaurus juntamente com Anaueria, Pavedadaphne Burger e Williamodendron no grupo Ocotea, subgrupo Mezilaurus.

Além de Mezilaurus, na região neotropical, Clinostemon, Licaria, Mocinnodaphne LoreaHernández, duas espécies de Aiouea e uma de Yasunia van der Werff compartilham a presença de flores bissexuadas, três estames férteis e anteras biloceladas. Clinostemon é caracterizado por apresentar anteras encurvadas e um par de glândulas nos filetes (Kuhlmann \& Sampaio 1928), enquanto Licaria possui folhas laxas nos ramos, inflorescências tirsoide-paniculadas e cúpula com dupla margem (Kurz 2000). Em Mocinnodaphne as folhas são triplinervadas, laxas nos ramos e a cúpula cupuliforme (Lorea-Hernández 1995); Aiouea apresenta as folhas laxas nos ramos e os estames férteis representam a série I do androceu (Kubitzki \& Renner 1982), enquanto Yasunia sessilifolia van der Werff (van der Werff \& Nishida 2010) possui folhas opostas, inflorescências paniculadas e tépalas decíduas na cúpula.

Baseado em análises moleculares do gene matK, Rohwer (2000) relatou que Mezilaurus formava um clado com Chlorocardium e Williamodendron. O autor utilizou somente uma espécie de cada gênero e questionou as relações do clado, justificando seu comentário baseandose em características florais e estrutura da madeira que diferenciavam claramente Mezilaurus e Williamodendron de Chlorocardium.

Chanderbali et al. (2001), em análises com quatro marcadores plastidiais (trnL-trnF, trnTtrnL, trnH-psbA e rpl16) e um nuclear (ITS), acrescentaram um maior número de terminais, 
indicando que Mezilaurus formava um clado com Anaueria, Chlorocardium e Sextonia, intitulando-o de "Chlorocardium-Mezilaurus".

Rohwer \& Rudolph (2005), com sequências de trnK, obtiveram resultado bastante semelhante. Os autores reconheceram o clado "grupo Mezilaurus" com os gêneros Anaueria, Chlorocardium, Mezilaurus, Sextonia e Williamodendron. Todavia, segundo Rohwer \& Rudolph (2005), a relação entre os gêneros não foi tão clara, já que, em diversas análises, há falta de resolução na relação de grupos-irmãos entre o clado Mezilauroides (Mezilaurus, Sextonia, Williamodendron) e o clado composto por Anaueria e Chlorocardium.

Dentro do clado Mezilauroides (sensu Rohwer \& Rudolph 2005), Mezilaurus, Sextonia e Williamodendron compartilham a presença de folhas congestas no ápice dos ramos como resultado de seu crescimento rítmico. Mezilaurus e Williamodendron possuem três estames férteis, representando a série III do androceu, ao passo que em Sextonia as flores apresentam nove estames férteis nas séries I, II e III do androceu (van der Werff 1997). Mezilaurus com anteras biloceladas e inflorescências do tipo duplo racemo (dibótrio), diferencia-se de Williamodendron que apresenta anteras tetraloceladas e inflorescências tirsoide-paniculadas (Kubitzki \& Richter 1987). Por outro lado, Anaueria e Chlorocardium possuem folhas opostas e crescimento contínuo nos ramos. Anaueria, com seis estames férteis por flor, anteras biloceladas e glândulas ausentes (Rohwer 1993a), diferencia-se de Chlorocardium que apresenta flores com 12-20 estames férteis, todos com glândulas e anteras tetraloceladas (Rohwer et al. 1991).

\subsection{Histórico do gênero Mezilaurus}

A história de Mezilaurus começou com a publicação de Allemão (1848), na qual é descrito o gênero Silvia, com uma única espécie, S. navalium Allemão. O autor justificou a criação do novo gênero, baseado na presença de três estames férteis e tépalas persistentes na 
cúpula do fruto. Allemão (1848) relatou que "formando esse gênero, quis restaurar o que Velloso propôs na sua Flora Fluminense para uma espécie de Escobedia (Scrophulariaceae), talvez pelo mesmo tempo, em que Ruiz e Pavon criavam esse gênero, que, sendo primeiro que o de Velloso conhecido na Europa prevaleceu". Segundo o autor (1848) o fato de Silvia Vell. (Vellozo 1829) ter sido sinonimizada em Escobedia Ruiz \& Pav. (Scrophulariaceae), era suficiente para restabelecer o nome Silvia para uma Lauraceae. Porém, mesmo sendo sinonimizado, o nome Silvia já havia sido validamente publicado e não poderia ter sido reutilizado.

Meissner (1864) reconheceu o homônimo entre Silvia Vell. (1829) e Silvia Allemão (1845) e propôs Silvaea Meisn., tranferindo Silvia navalium Allemão para Silvaea navalium (Allemão) Meisn. Bentham \& Hooker (1880) não aceitaram o gênero e transferiram S. navalium Allemão e Acrodiclidium itauba Meisn. para Endiandra R. Br. Pax (1889), por outro lado, reconsiderou o gênero Silvia como parte de Lauroideae-Acrodiclidieae, juntamente com Acrodiclidium, Misanteca e Endiandra e transferiu Acrodiclidium itauba para Silvia Allemão. Com a mesma atitude, Mez (1889) tratou as Lauraceae americanas e continuou aceitando Silvia Allemão, relatando a ocorrência de seis espécies do gênero. Além de Silvia navalium, o autor transferiu Oreodaphne crassiramea Meisn., Acrodiclidium itauba Meisn., A. anacardioides Spruce ex Meisn., A. sprucei Meisn. e A. oppositifolium Nees para Silvia Allemão.

Silvaea Meisn. também possuía um homônimo, Silvaea Phil. (Philippi 1860) (Portulacaceae). Kuntze (1891) reconheceu esse homônimo e indicou Mezia para substituir Silvia Allemão e Silvaea Phil. O autor transferiu para Mezia, espécies anteriormente descritas em outros gêneros para a circunscrição proposta para Silvia Allemão (1848). As espécies transferidas foram Oreodaphne crassiramea, Silvia navalium, Acrodiclidium itauba, A. anacardioides, A. sprucei e A. oppositifolia. Portanto, Mez (1889) e Kuntze (1891) foram os primeiros autores a estabelecer uma circunscrição mais bem definida para o gênero, aglutinando espécies anteriormente estabelecidas em outros gêneros. 
Mezia Kuntze também possuía um homônimo anterior, Mezia Schwacke, uma Malpighiaceae (Niedenzu 1890). Por fim Taubert (1892) propôs Mezilaurus para substituir todos estes nomes. No mesmo ano, Mez (1892) reconheceu e aplicou Mezilaurus, relatando a ocorrência de seis espécies e descrevendo Mezilaurus lindaviana Schwacke \& Mez. Posteriormente, Pax (1897) também reconheceu Mezia Kuntze como homônimo de Mezia Schwacke (Niedenzu 1890) e propôs Neosilvia Pax para substituir Silvia Allemão. Como já existia um nome para substituir Silvia Allemão, Neosilvia é, portanto, um nomem superfluo.

No entanto, Mez (1920) descreveu Silvia synandra ainda com o nome genérico proposto por Allemão (1848). Em 1935, a conservação de Silvia Allemão contra Silvia Vellozo e Silvia Benth., foi proposta por Rehder et al. (1935), porém, o procedimento foi rejeitado.

Kostermans (1936a) aplicou o nome genérico correto, Mezilaurus, segundo o Código Internacional de Nomenclatura Botânica, realizando as novas combinações para Mezilaurus subcordata, M. decurrens e M. synandra.

Em revisão do gênero, Kostermans (1938c) citou a ocorrência de oito espécies de Mezilaurus, relatando sua proximidade com Licaria e Endiandra. O autor escolheu lectótipos (inferencialmente) para Mezilaurus crassiramea, M. lindaviana, M. navalium, M. decurrens, M. synandra, M. subcordata, M. itauba e M. sprucei.

Kostermans (1938c) não aceitou Clinostemon, um gênero criado por Kuhlmann \& Sampaio (1928) baseado em Acrodiclidium mahuba A. Samp. Kostermans (1938c) realizou a combinação de Acrodiclidium mahuba em Licaria. Kubitzki et al. (1979) restabeleceram Clinostemon, com C. mahuba Kuhlm. \& A. Samp. e transferiram Licaria maguireana C. K. Allen para este gênero.

Van der Werff (1987) revisou Mezilaurus relatando a ocorrência de 18 espécies, sendo oito novas. $\mathrm{O}$ autor aumentou a circunscrição do gênero, incluindo Clinostemon e duas espécies com quatro locelos, M. glaucophylla van der Werff e M. quadrilocellata van der Werff. No 
mesmo ano, Williamodendron foi descrito por Kubitzki \& Richter (1987) com as duas espécies de Mezilaurus com quatro locelos tratadas por van der Werff (1987). Desde então, quatro novas espécies foram descritas para Mezilaurus (van der Werff 1994, 2003; Alves \& Baitello 2008).

Portanto, até ser definido como Mezilaurus, suas espécies foram apontadas como Silvia Allemão, homônimo posterior de Silvia Vell. (Scrophulariaceae), Silvaea Meisn., homônimo posterior de Silvaea Phil. (Portulacaceae), Mezia Kuntze, homônimo posterior de Mezia Schwacke (Malpighiaceae); Misanteca, Acrodiclidium (sinônimos de Licaria), Licaria, Endiandra ou Clinostemon (Lauraceae).

Relatos sobre o histórico taxonômico de Mezilaurus são encontrados também em Mez (1892), Kostermans (1936a), Kostermans (1952b), Bernard (1962) e van der Werff (1987). 


\section{Objetivos}

- O presente trabalho teve como objetivo utilizar sequências dos marcadores moleculares trnH-psbA e ITS para realizar um estudo filogenético molecular com a finalidade de testar o monofiletismo do gênero Mezilaurus e compreender as relações deste com os demais gêneros do "grupo Mezilaurus" (sensu Rohwer \& Rudolph 2005).

- Baseado no resultado do estudo de filogenia molecular, o trabalho também apresentou como finalidade realizar uma revisão taxonômica de Clinostemon e Mezilaurus, apresentando descrições, chaves de identificação, ilustrações, mapas de distribuição geográfica e comentários taxonômicos atualizados para cada espécie. 


\section{Material e Métodos}

\subsection{Estudo Filogenético}

Foram incluídos 25 terminais para a análise com trnH-psbA e 24 para o ITS, representando 24 espécies e 13 gêneros de Lauraceae. O grupo-interno foi composto por nove espécies do gênero Mezilaurus. Para o grupo-externo foram incluídas todas as espécies dos gêneros Anaueria (A. brasiliensis), Chlorocardium (C. rodiei e C. venenosum) e Sextonia (S. pubescens e S. rubra), além de uma espécie das três conhecidas de Williamodendron ( $W$. cinnamomeum). Foram incluídas também como grupo-externo, cinco espécies do core Lauraceae sensu Rohwer \& Rudolph (2005) (Persea americana [grupo Persea], Licaria triandra, Pleurothyrium cinereum, Ocotea odorifera e Umbellularia californica [complexo Ocotea]), duas espécies de Caryodaphnopsis (C. laotica e C. tonkinensis) e duas da tribo Cryptocaryeae sensu van der Werff \& Richter (1996) (Beilschmiedia robusta e Cryptocarya saligna).

Anaueria, Chlorocardium, Mezilaurus e Sextonia emergiram como um grupo monofilético nas análises de Chanderbali et al. (2001), intitulado pelos autores como clado Chlorocardium-Mezilaurus. No trabalho de Rohwer \& Rudolph (2005) este clado foi denominado "grupo Mezilaurus", incluindo também Williamodendron. O core Lauraceae (Perseeae-Laureae), emergiu como grupo-irmão do clado "grupo Mezilaurus", enquanto Caryodaphnopsis surgiu como grupo-irmão de core Lauraceae + "grupo Mezilaurus" nas análises de Rohwer (2000), Chanderbali et al. (2001) e Rohwer \& Rudolph (2005). Cryptocaryeae sensu van der Werff \& Richter (1996) emergiu como próximo do grupo-irmão de Caryodaphnopsis + core Lauraceae (Perseeae-Laureae) + "grupo Mezilaurus" nos trabalhos de Rohwer (2000), Chanderbali et al. (2001) e Rohwer \& Rudolph (2005). 
O trabalho de extração de DNA e amplificação foi realizado no Laboratório de Fitoquímica e Sistemática Molecular do Departamento de Botânica do Instituto de Biociências da Universidade de São Paulo. O sequenciamento foi realizado no GaTE lab - Genomics and Transposable Elements Lab, Departamento de Botânica-IB-USP.

O protocolo de extração do DNA utilizou detergente catiônico CTAB (Cationic hexadecyl Trimethyl Ammonium Bromide), baseado no protocolo de Ferreira \& Grattapaglia (1996), modificado de Doyle \& Doyle (1987) com base, principalmente, em 20-30 mg de folhas coletadas e desidratadas com sílica gel (Chase \& Hills 1991). Tecido vegetal para a extração do DNA também foi obtido de espécimes herborizados (Tabela 1). No caso do material vegetal proveniente de exemplares de herbário, após a primeira etapa da extração, as amostras permaneceram à temperatura entre $-5 \mathrm{e}-10^{\circ} \mathrm{C}$ para precipitação do "pellet" por sete dias.

Os iniciadores utilizados para a amplificação do trnH-psbA foram os $p s b A$ e $\operatorname{trn} H$ (Tate \& Simpson 2003), enquanto para o ITS, AB101F e AB102R (Douzery et al. 1999). As sequências dos iniciadores utilizados para a amplificação estão incluídas na tabela 2.

A amplificação foi realizada com uma reação de PCR (Reação em Cadeia da Polimerase) com volume total de $50 \mu$ l, utilizando um termociclador Mastercycler ${ }^{\circledR}$. Os componentes da reação foram os seguintes:

- trnH-psbA: $10 \mu 1$ de Buffer Go Taq 5x $+3 \mu 1$ de DNTP 0,25 M + $5 \mu 1$ de Betaina 0,5 M + $1 \mu \mathrm{l}$ do iniciador $p s b A+1 \mu \mathrm{l}$ do iniciador $\operatorname{trn} H+2 \mu \mathrm{l}$ de $\mathrm{MgCl}_{2}+0,25 \mu \mathrm{l}$ de Taq Polimerase $+25,75 \mu 1$ de água milique $+2 \mu 1$ de DNA.

- ITS: $10 \mu \mathrm{l}$ de Buffer Go Taq 5x $+4 \mu 1$ de DNTP 0,25 M $+4 \mu 1$ de DMSO (dimetil sulfóxido) $+5 \mu 1$ de Betaina $0,5 \mathrm{M}+1 \mu 1$ do iniciador AB101 $+1 \mu 1$ do iniciador AB102 $+4 \mu 1$ de $\mathrm{MgCl}_{2}+0,25 \mu 1$ de Taq Polimerase $+18,75 \mu 1$ de água milique $+2 \mu 1$ de DNA. 
Tabela 1: Espécies com seus respectivos vouchers que tiveram seu DNA extraído para o trabalho de filogenia molecular (*espécimes herborizados).

\begin{tabular}{|c|c|c|}
\hline Espécies & Voucher & Localidade \\
\hline $\begin{array}{c}\text { Clinostemon mahuba (A. Samp.) Kuhlm. } \\
\& \text { A. Samp. }\end{array}$ & F. M. Alves 528 & Belém (PA) \\
\hline Cryptocarya saligna $\mathrm{Mez}$ & P. L. R. de Moraes 2477* & Ubatuba (SP) \\
\hline $\begin{array}{l}\text { Mezilaurus crassiramea (Meisn.) Taub. } \\
\text { ex Mez }\end{array}$ & F. M. Alves 530 & Campo Grande (MS) \\
\hline Mezilaurus duckei van der Werff & F. M. Alves 524 & Manaus (AM) \\
\hline $\begin{array}{c}\text { Mezilaurus glabriantha F. M. Alves \& } \\
\text { V. C. Souza sp. nov. }\end{array}$ & $\begin{array}{l}\text { T. D. M. Barbosa \& F. M. } \\
\text { Alves } 1012\end{array}$ & Santa Teresa (ES) \\
\hline $\begin{array}{c}\text { Mezilaurus itauba (Meisn.) Taub. ex } \\
\text { Mez }\end{array}$ & F. M. Alves 523 & Manaus (AM) \\
\hline $\begin{array}{c}\text { Mezilaurus microphylla F. M. Alves \& } \\
\text { V. C. Souza sp. nov. }\end{array}$ & G. F. Árbocz 6491* & $\begin{array}{l}\text { Miracema do } \\
\text { Tocantins (TO) }\end{array}$ \\
\hline Mezilaurus navalium (Meisn.) Taub. ex Mez & H. C. de Lima et al. $5861^{*}$ & Nova Iguaçu (RJ) \\
\hline Mezilaurus synandra (Mez) Kosterm. & G. F. Árbocz $6476^{*}$ & Porto Nacional (TO) \\
\hline $\begin{array}{c}\text { Mezilaurus vanderwerffii F. M. Alves \& } \\
\text { J. B. Baitello }\end{array}$ & F. M. Alves \& W. Garcez 45 & Aquidauana (MS) \\
\hline Sextonia rubra (Mez) van der Werff & F. M. Alves 525 & Manaus (AM) \\
\hline $\begin{array}{l}\text { Williamodendron cinnamomeum van der } \\
\text { Werff }\end{array}$ & F. M. Alves 531 & Santa Teresa (ES) \\
\hline
\end{tabular}

Tabela 2: Regiões moleculares com as sequências de seus iniciadores utilizadas nas análises filogenéticas.

\begin{tabular}{|c|c|c|}
\hline Região & Sequência do iniciador & Referência \\
\hline $\operatorname{trnH}-p s b A$ & $\begin{array}{l}\text { trnH }- \text { 5' CGCGCATGGTGGATTCACAATCC 3' }^{\prime} \\
\text { (direto) } \\
p s b A-5^{\prime} \text { GTTATGCATGAACGTAATGCTC 3' } \\
\text { (reverso) }\end{array}$ & $\begin{array}{c}\text { Tate \& Simpson } \\
\quad(2003)\end{array}$ \\
\hline $\begin{array}{l}\text { ITS (ITS } 1, \\
5.8 \text { S e ITS2) }\end{array}$ & $\begin{array}{l}\text { AB 101F - 5' ACGAATTCATGGTCCGGTGAAGTGTT 3' } \\
\text { (direto) } \\
\text { AB 102R - 5' TAGAATTCCCCGGTTCGCTCGCCGTT 3' } \\
\text { (reverso) }\end{array}$ & $\begin{array}{c}\text { Douzery et al. } \\
\qquad(1999)\end{array}$ \\
\hline
\end{tabular}

A programação utilizada para a amplificação foi a mesma para o trnH-psbA e o ITS: $96^{\circ} \mathrm{C}$ por 2 minutos +40 ciclos $\left(96^{\circ} \mathrm{C}\right.$ por 2 minutos, $49^{\circ} \mathrm{C}$ por 45 segundos, $72^{\circ} \mathrm{C}$ por 1 minuto e $72^{\circ} \mathrm{C}$ por 7 minutos). 
O produto, quando verificado êxito da amplificação com a técnica de eletroforese, foi purificado, com a utilização o kit de purificação GFX PCR DNA \& Gel Band (GE Healthcare).

A reação de sequenciamento foi realizada com volume total de $10 \mu 1$ contendo: $0,3 \mu 1$ do iniciador $+2 \mu 1$ de Big Dye $+1-4 \mu 1$ de DNA (de acordo com a intensidade da banda amplificada) $+3,7-6,7 \mu 1$ de água milique (complementar o volume total de $10 \mu 1$ ). A programação do termociclador utilizada foi: 40 ciclos de $96{ }^{\circ} \mathrm{C}$ por 1 minuto $+96{ }^{\circ} \mathrm{C}$ de 10 segundos $+52{ }^{\circ} \mathrm{C}$ por 20 segundos e $60{ }^{\circ} \mathrm{C}$ por 4 minutos.

O sequenciamento foi realizado com os sequenciadores automáticos 3730DNA e 3130XL (Applied Biosystems). A avaliação da qualidade das sequências foi realizada no Sequence Scanner 1.0 (Applied Biosystems) e a edição e alinhamento, realizados no BioEdit 7.0.9 (Hall 1999) com posterior refinamento manual segundo as sugestões de Kelchner (2000). Os "gaps" foram codificados em uma matriz binária e incluídos no final das matrizes, segundo proposta de Simmons \& Ochoterena (2000). Algumas sequências foram também adquiridas do GenBank (www.ncbi.nlm.nih.gov/genbank/) (Tabela 3).

A reconstrução filogenética foi realizada com os marcadores moleculares separadamente e com dados combinados entre eles. Para a análise de Parcimônia utilizou-se o programa PAUP 4.0 (Swofford 2002), com otimização dos estados de caráter "ACCTRAN", busca heurística e 1000 réplicas ao acaso, armazenando 20 árvores por réplicas, adição das sequências de modo aleatório e "Tree Bisection Reconnection" (TBR) com exposição de valores de bootstrap acima de 50\%. Foi utilizado o consenso estrito a fim de resolver os conflitos entre as árvores mais parcimoniosas. Os valores de bootstrap (Felsenstein 1985) foram obtidos para verificar o suporte dos clados presentes nos cladogramas. 
Tabela 3: Espécies que tiveram suas sequências de trnH-psbA e ITS extraídas do GenBank com os respectivos números de acesso. * Citada como Mezilaurus triunca van der Werff por Chanderbali et al. (2001).

\begin{tabular}{lcc}
\hline Espécies & \multicolumn{2}{c}{ Número de acesso Genbank } \\
\hline & trnH-psbA & ITS \\
\cline { 2 - 3 } Anaueria brasiliensis Kosterm. & AF268800 & FM957800 \\
Beilschmiedia robusta C. K. Allen & GU117747 & GU082363 \\
Caryodaphnopsis laotica Airy Shaw & GU117749 & GU082365 \\
$\begin{array}{ll}\text { C. tonkinensis (Leconte) Airy Shaw } \\
\text { Chlorocardium rodiei } \text { (R. H. Schomb.) Rohwer, H. G. }\end{array}$ & GU117748 & GU082364 \\
Richt. \& van der Werff & AF268802 & AF272258 \\
C. venenosum (Kosterm. \& Pinkley) Rohwer, H. G. Richt. & & \\
\& van der Werff & AF268801 & AF272259 \\
Licaria triandra (Sw.) Kosterm. & AF268774 & AF272282 \\
Mezilaurus mahuba (A. Samp.) van der Werff & AF268804 & AF272287 \\
Ocotea odorifera Rohwer & AF268762 & AF272309 \\
Persea americana Mill. & AF268794 & AF272322 \\
Pleurothyrium cinereum van der Werff & AF268769 & AF272329 \\
Sextonia pubescens van der Werff & AF262000 & AF268808 \\
Umbellularia californica (Hook. \& Arn.) Nutt. & AF268777 & AF272337 \\
\hline
\end{tabular}

A análise Bayesiana foi realizada com o programa MrBayes (Ronquist \& Huelsenbeck 2001), utilizando os modelos evolutivos selecionados pelo MrModeltest 2.2 (Nylander 2005), teste "Hierarchical Likelihood Tests (hLRTs)", 10 milhões de gerações. O espaçamento utilizado foi de 1000 e as árvores anteriores ao "Burnin" foram eliminadas. A árvore de consenso de maioria e as probabilidades posteriores foram determinadas e adotadas para expressar os resultados. O programa TreeView (Page 1996) foi usado a fim de visualizar os cladogramas. 


\subsection{Estudo Taxonômico}

O trabalho de revisão taxonômica foi baseado principalmente na análise de aproximadamente 550 espécimes de exsicatas botânicas, depositadas em cerca de 60 herbários nacionais e internacionais. A análise das coleções brasileiras e algumas sul-americanas foi realizada pessoalmente ou por solicitação de empréstimo de exsicatas, analisadas no Herbário ESA da Escola Superior de Agricultura "Luiz de Queiroz" - ESALQ, Universidade de São Paulo (USP) em Piracicaba-SP.

Parte da análise dos espécimes dos herbários europeus e americanos foi realizada no Royal Botanic Garden (Kew), Londres, com a solicitação de empréstimo de exsicatas. Determinados herbários europeus tiveram suas exsicatas estudadas também pessoalmente, enquanto alguns herbários americanos foram analisados através de fotografias de alta resolução.

Os espécimes analisados foram oriundos das coleções dos herbários listados a seguir (*coleção analisada pessoalmente; **coleção solicitada de empréstimo; *** coleção analisada através de fotografias de alta resolução).

AAU - Department of Biological Sciences University of Aarhus, Aarhus, Dinamarca ***

ALCB - Universidade Federal da Bahia, Campus Universitário de Ondina, Salvador, Brasil*

ASE - Herbário da Universidade Federal de Sergipe, São Cristóvão, Brasil*

B - Botanischer Garten und Botanisches Museum Berlin-Dahlem, Zentraleinrichtung der Freien

Universität Berlin, Berlim, Alemanha*

BHCB - Universidade Federal de Minas Gerais, Belo Horizonte, Brasil*

BM - The Natural History Museum, Londres, Inglaterra*

BR - National Botanic Garden of Belgium, Meise, Bélgica*

$\mathrm{C}$ - University of Copenhagen, Copenhague, Dinamarca** 
CEN - Herbário da Embrapa Recursos Genéticos e Biotecnologia*

CEPEC - Centro de Pesquisas do Cacau, Itabuna, Brasil*

CGMS - Universidade Federal de Mato Grosso do Sul, Campo Grande, Brasil*

COL - Herbário Nacional da Colômbia, Bogotá, Colômbia***

COR - Universidade Federal de Mato Grosso do Sul, Corumbá, Brasi1*

CPAP - EMBRAPA Pantanal, Corumbá, Brasil*

CVRD - Reserva Natural da Vale do Rio Doce, Linhares, Brasil**

E - Royal Botanic Garden Edinburgh, Edimburgo, Escócia***

ESA - Escola Superior de Agricultura “Luiz de Queiroz” - ESALQ, Piracicaba, Brasil*

F - Field Museum of Natural History, Chicago, Estados Unidos***

$\mathrm{G}$ - Conservatoire et Jardin botaniques de la Ville de Genève, Genebra, Suiça*

G-DC - Conservatoire et Jardin botaniques de la Ville de Genève, Genebra, Suiça*

GUA - Fundação Estadual de Engenharia do Meio Ambiente, Rio de Janeiro, Brasil*

HAMAB - Instituto de Pesquisas Científicas e Tecnológicas do Amapá, Macapá, Brasil*

HB - Herbarium Bradeanum, Rio de Janeiro, Brasil*

HBG - Universität Hamburg - Fachbereich Biologie Biozentrum Klein Flottbek, Hamburgo,

Alemanha**

HMS - Embrapa Gado de Corte Brasil, Campo Grande, Brasi1*

HPL - Instituto Plantarum de Estudos da Flora, Nova Odessa, Brasil*

HRB - IBGE, Jardim Botânico de Salvador, Salvador, Brasil*

HRCB - Universidade Estadual Paulista, Brasil*

HUEFS - Universidade Estadual de Feira de Santana, Feira de Santana, Brasil*

HUNEB - Universidade do Estado da Bahia, Alagoinhas, Brasi1*

HTO - Universidade Federal do Tocantins, Porto Nacional, Brasil**

IAC - Instituto Agronômico de Campinas, Campinas, Brasil*

IAN - Embrapa Amazônia Oriental, Belém, Brasil*

IBGE - Reserva Ecológica do IBGE, Brasília, Brasil*

INPA - Instituto Nacional de Pesquisas da Amazônia, Manaus*

IPA - Empresa Pernambucana de Pesquisa Agropecuária (IPA), Recife, Brasil*

$\mathrm{K}$ - Royal Botanic Gardens, Londres, Inglaterra*

L - Nationaal Herbarium Nederland, Leiden University branch, Leiden, Holanda* 
LPB - Herbário Nacional da Bolívia, La Paz, Bolívia**

M - Botanische Staatssammlung München, Munique, Alemanha*

MAC - Instituto do Meio Ambiente, Maceió, Brasil*

MBM - Museu Botânico Municipal, Curitiba, Brasil*

MBML - Museu de Biologia Mello Leitão, Santa Teresa, Brasil*

MG - Museu Paraense Emílio Goeldi, Belém, Brasil*

MIRR - Museu Integrado de Roraima, Boa Vista, Brasi1**

MO - Missouri Botanical Garden, Saint Louis, Estados Unidos**

NY - New York Botanical Garden, Nova York, Estados Unidos***

OXF - University of Oxford, Oxford, Inglaterra*

PAMG - Empresa de Pesquisa Agropecuária de Minas Gerais - EPAMIG*

P - Muséum National d'Histoire Naturelle, Paris, França*

PEUFR - Universidade Federal Rural de Pernambuco, Recife, Brasil*

R - Museu Nacional do Rio de Janeiro, Rio de Janeiro, Brasil*

RB - Jardim Botânico do Rio de Janeiro, Rio de Janeiro, Brasil*

SP - Instituto de Botânica Brasil, São Paulo, Brasil*

SPF - Universidade de São Paulo, São Paulo, Brasil*

SPSF - Instituto Florestal, São Paulo, Brasil*

U - National Herbarium of the Netherlands, Herbarium Utrecht, Leiden, Holanda*

UB - Universidade de Brasília, Brasília, Brasil*

UEC - Universidade Estadual de Campinas, Campinas, Brasil*

UFG - Universidade Federal de Goiás, Goiânia, Brasil*

UFP - Universidade Federal de Pernambuco, Recife, Brasil*

UFMT - Universidade Federal de Mato Grosso, Cuiabá, Brasil*

UPCB - Universidade Federal do Paraná, Curitiba, Brasi1*

US - Smithsonian Institution, Washington, Estados Unidos***

VEN - Fundación Instituto Botánico de Venezuela Dr. Tobías Lasser, Herbario Nacional de

Venezuela, Caracas, Venezuela**

VIES - Universidade Federal do Espírito Santo, Vitória, Brasil*

W - Naturhistorisches Museum Wien, Viena, Austria* 
Viagens de coleta foram realizadas para observar as plantas em campo, coletar material para herborização e extração de DNA para filogenia molecular (Tabela 4). Os espécimes foram herborizados, incorporados ao herbário ESA e enviados para o CGMS e SPF.

Tabela 4: Expedições de campo realizadas diferentes regiões do Brasil e espécies coletadas.

\begin{tabular}{|c|c|c|}
\hline Local de Coleta & Datas & Espécies coletadas \\
\hline Amazonas. Manaus: Reserva Ducke & $\mathrm{abril} / 2008$ & $\begin{array}{c}\text { Mezilaurus itauba, M. synandra, } \\
\text { M. duckei e Sextonia rubra }\end{array}$ \\
\hline $\begin{array}{l}\text { Espírito Santo. Santa Teresa: Reserva } \\
\text { Florestal de Santa Lúcia }\end{array}$ & novembro/2008 & $\begin{array}{l}\text { M. glabriantha } \mathrm{e} \\
\text { Williamodendron cinnamomeum }\end{array}$ \\
\hline Mato Grosso do Sul. Aquidauana: & & \\
\hline Morro do Paxixi & agosto/2010 & M. vanderwerffii \\
\hline $\begin{array}{l}\text { Mato Grosso do Sul. Aquidauana: } \\
\text { Piraputanga }\end{array}$ & novembro/2010 & M. vanderwerffii \\
\hline Goiás. Goiás: Serra Dourada & outubro/2010 & M. crassiramea \\
\hline Pará. Belém: Parque do Museu Goeldi & novembro/2010 & Clinostemon mahuba \\
\hline Amapá. Macapá, IEPA & novembro/2010 & M. crassiramea \\
\hline $\begin{array}{l}\text { Mato Grosso do Sul. Campo Grande: } \\
\text { Parque dos Poderes }\end{array}$ & fevereiro/2011 & M. crassiramea \\
\hline
\end{tabular}

A nomenclatura morfológica adotada nas descrições foi baseada em Font Quer (1953), Radford et al. (1974) e Harris \& Harris (1994) e o tipo de nervação, segundo Hickey (1973). O padrão de ritidoma utilizado foi sugerido por Ribeiro et al. (1999). Os protólogos nos cabeçalhos taxonômicos foram citados com base em Stafleu \& Cowan (1976, 1979, 1981, 1983, 1985, 1986), enquanto as revistas nas referências bibliográficas foram referidas com o nome completo. Para o nome dos autores das plantas foi seguido Brummit \& Powell (1992) e os herbários conforme Holmgren et al. (1990). No presente trabalho, o diâmetro dos râmulos foi medido a 5 centímetros do ápice. 
Dentro da revisão taxonômica de Mezilaurus lato sensu, foi utilizado Morrone (2001) para descrever a distribuição geográfica das espécies dentro de províncias nas sub-regiões Amazônica, Chaquenha e Paranaense (Figura 1). As avaliações sobre os status de conservação de cada espécie foram realizadas baseadas nos critérios e categorias da IUCN (2001).

As ilustrações das espécies foram confeccionadas com o auxílio de uma câmara clara acoplada a um estereomicroscópio Olympus, utilizando espécimes herborizados. As coordenadas geográficas de cada espécime foram obtidas a partir das informações das exsicatas. Os mapas de distribuição geográfica foram confeccionados utilizando os programas Excel e ArcMap. As referências apresentadas sobre formações vegetacionais em que as espécies ocorrem foram obtidas a partir das observações de campo e informações contidas nas etiquetas que acompanham o material herborizado. Já as fotos de microscopia eletrônica de varredura foram realizadas no Laboratório de Microscopia Eletrônica Aplicada (NAP/MEPA) da Escola Superior de Agricultura "Luiz de Queiroz" - ESALQ/USP.

No presente trabalho são aceitas as lectotipificações inferenciais realizadas por Kostermans (1938c) e van der Werff (1987). Segundo o Código Internacional de Botânica no seu Artigo 7.11 "Para fins de prioridade (Art. 9.17, 9.18 e 10.5), a designação de um tipo só é consumada se o tipo for definitivamente aceito como tal pelo autor que efetivou a tipificação, se o elemento-tipo for claramente indicado pela citação direta, incluindo o termo "tipo" (typus) ou equivalente e, em ou a partir de $1^{\circ}$ de janeiro de 2001 se a afirmação da tipificação incluir a frase “ designado aquil” (hic designatus) ou algo equivalente. "Nota. 2. Os Art. 7.10 e 7.11 aplicam-se apenas a designações de lectótipos (e seus equivalentes conforme o Art. 10), neótipos e epítipos; para a indicação de holótipo veja Art. 37” (McNeill et al. 2007). 


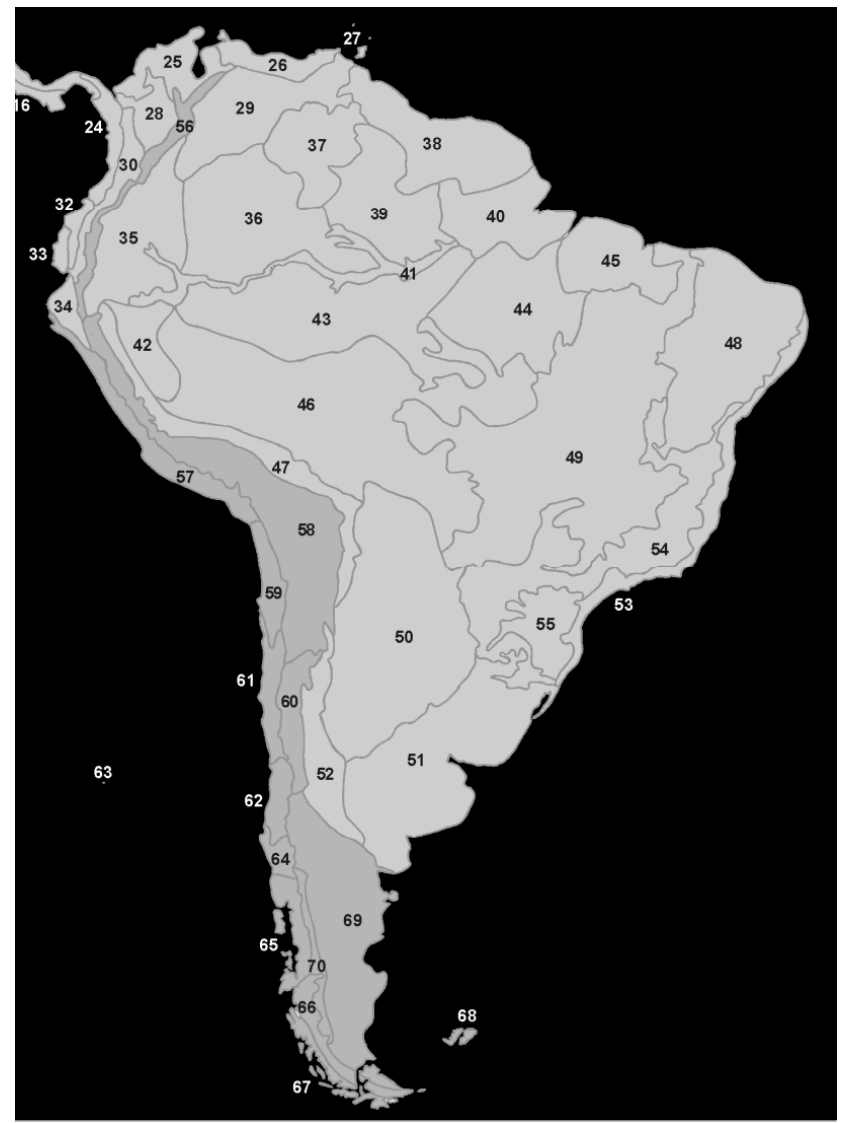

\begin{tabular}{llr} 
Subregiones & Provincias & $\begin{array}{c}\text { Número } \\
\text { en Fig. 1 }\end{array}$ \\
Amazónica & Napo & 35 \\
& Imerí & 36 \\
& Guyana & 37 \\
& Guyana Húmeda & 38 \\
& Roraima & 39 \\
& Amapá & 40 \\
& Varzea & 41 \\
& Ucayali & 42 \\
& Madeira & 43 \\
& Tapajós-Xingú & 44 \\
& Pará & 45 \\
& Pantanal & 46 \\
& Yungas & 47 \\
\hline Chaqueña & Caatinga & 48 \\
& Cerrado & 49 \\
& Chaco & 50 \\
& Pampa & 51 \\
& Monte & 52 \\
& Bosque Atlántico Brasileño & 53 \\
& Bosque Paranaense & 54 \\
& Bosque de Araucaria angustifolia & 55 \\
& &
\end{tabular}

Figura 1: Mapa com classificação biogeográfica da América do Sul proposta por Morrone (2001) (Figura: Morrone 2001). 


\section{Resultados e Discussão}

\subsection{Relações filogenéticas de Mezilaurus Taub. (Lauraceae)}

Os parâmetros utilizados nas análises de Parcimônia e Bayesiana com o trnH-psbA, ITS e os marcadores moleculares combinados estão listados abaixo na tabela 5.

Tabela 5: Caracterização das análises de Parcimônia e Bayesiana com os marcadores trnH-psbA, ITS e ambos combinados.

\begin{tabular}{|c|c|c|c|}
\hline \multirow[t]{2}{*}{ Parâmetros } & \multicolumn{3}{|c|}{ Marcadores } \\
\hline & $\operatorname{trnH}-p s b A$ & ITS & $\operatorname{trnH}-p s b A+I T S$ \\
\hline $\mathrm{N}^{\circ}$ de terminais do grupo-interno & 10 & 9 & 9 \\
\hline $\mathrm{N}^{\circ}$ de terminais do grupo-externo & 15 & 15 & 15 \\
\hline \multirow[t]{2}{*}{$\mathrm{N}^{\circ}$ de caracteres } & 432 & 847 & 1279 \\
\hline & \multicolumn{2}{|c|}{ Parcimônia } & \\
\hline $\mathrm{N}^{\circ}$ de caracteres constantes & 308 & 405 & 713 \\
\hline $\mathrm{N}^{\circ}$ de caracteres não informativos & 43 & 86 & 129 \\
\hline $\begin{array}{c}\mathrm{N}^{\circ} \text { de caracteres parcimoniosamente } \\
\text { informativos }\end{array}$ & 81 & 356 & 437 \\
\hline $\mathrm{N}^{\circ}$ de árvores mais parcimoniosas & 12352 & 1234 & 1326 \\
\hline $\mathrm{N}^{\circ}$ de passos & 176 & 798 & 990 \\
\hline Índice de consistência (IC) & 0,77 & 0,65 & 0,66 \\
\hline \multirow[t]{2}{*}{ Índice de retenção (IR) } & 0,85 & 0,8 & 0,8 \\
\hline & \multicolumn{2}{|c|}{ Bayesiana } & \\
\hline Modelo evolutivo & GTR & $\mathrm{HKY}+\mathrm{G}$ & $\mathrm{HKY}+\mathrm{G}$ \\
\hline "Burnin" & 5 & 12 & 14 \\
\hline
\end{tabular}

Foi encontrada, no presente trabalho, melhor resolução nas análises com ITS ou os marcadores combinados quando comparada com o trnH-psbA isoladamente (Figuras 2-7). Sequências de ITS confirmaram ser claramente mais informativas, quando comparadas com as 
plastidiais (Mort et al. 2007). O ITS também evidenciou substancial variação e importância para demonstrar relações dentro de Lauraceae (Chanderbali et al. 2001; Li et al. 2004; Li et al. 2008; Assis 2010; Rohwer et al. 2009; Wang et al. 2010) bem como em muitos outros táxons de fanerógamas (Baldwin 1992; Baldwin et al. 1995; Downie \& Katz-Downie 1996).

Chanderbali et al. (2001) demonstrou também que, sequências plastidiais (trnL-trnF, trnH-psbA, trnT-trnL, rpl16) podem ser informativas dentro de Lauraceae. Enquanto, segundo Soltis et al. (2011), a combinação de marcadores moleculares é importante para que as relações filogenéticas possam ser mais bem esclarecidas. 


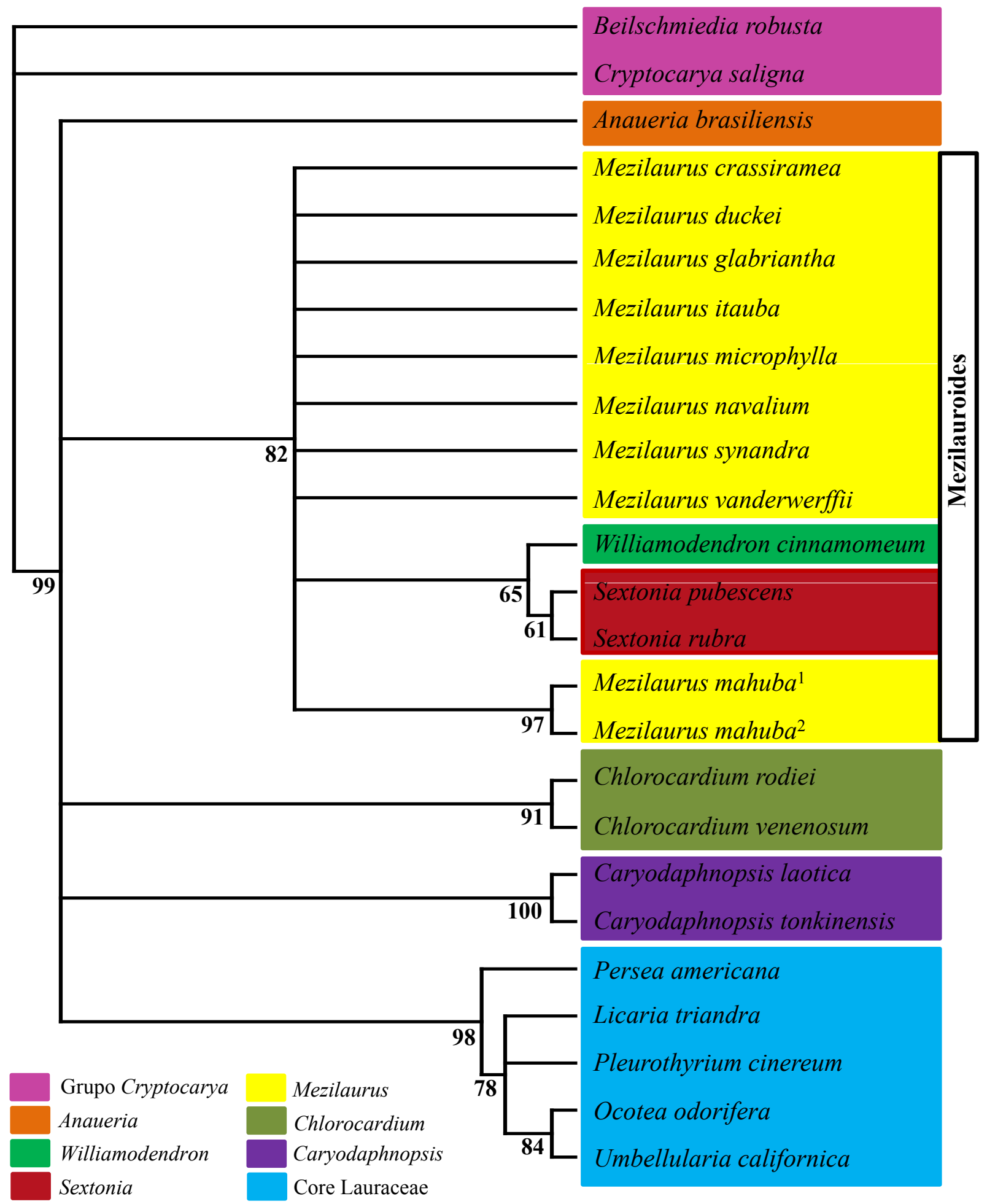

Figura 2: Cladograma de consenso estrito entre os mais parcimoniosos da análise de Parcimônia baseada em trnH-psbA. Valores nos nós representam os índices de bootstrap superiores à $50 \%$. Análise com índice de consistência (IC) $=0,77$ e índice de retenção (IR) $=0,85 .{ }^{1}$ Espécime coletado no presente trabalho; ${ }^{2}$ Espécime referido como M. triunca por Chanderbali et al. (2001). 


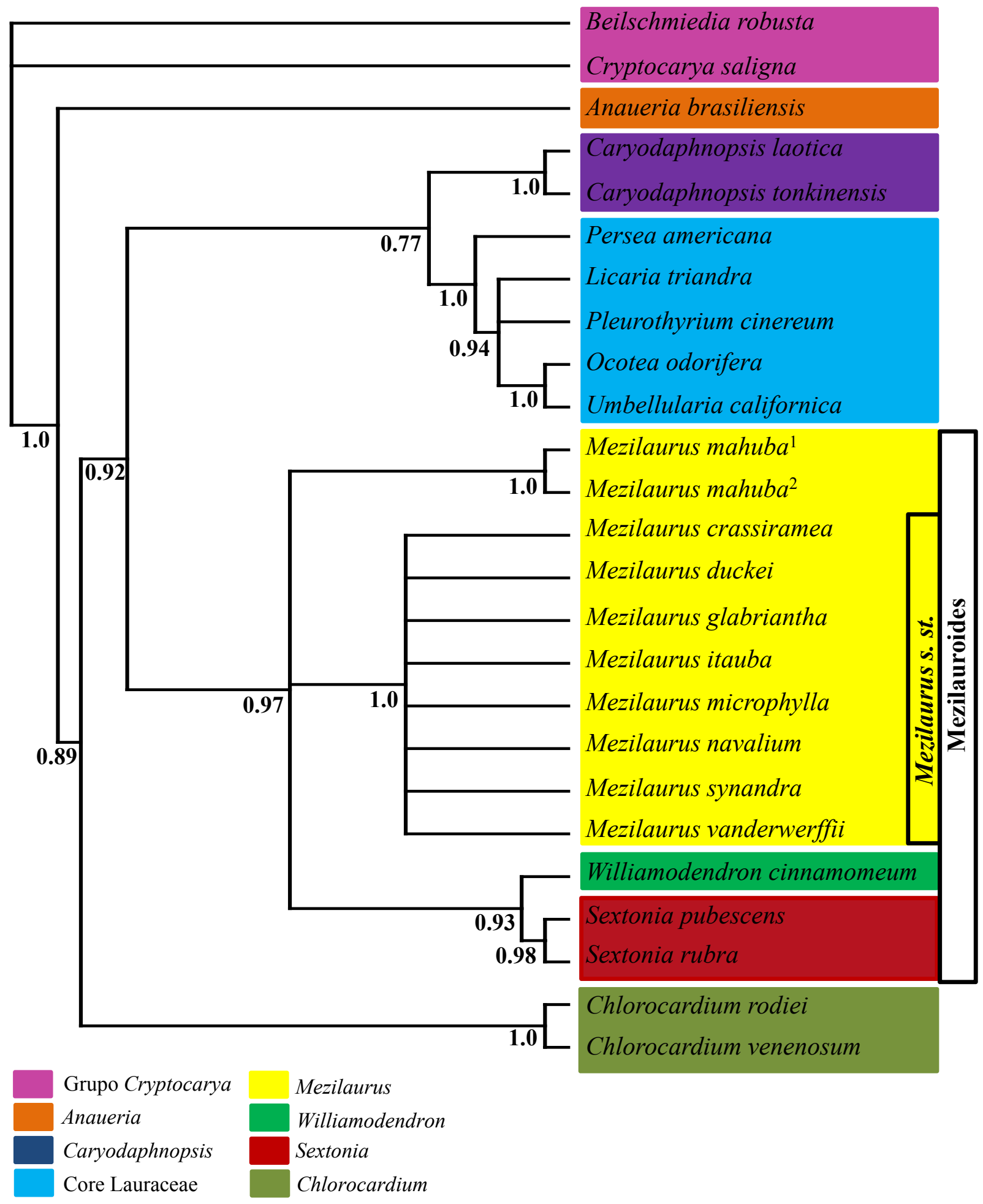

Figura 3: Cladograma de consenso de maioria da análise Bayesiana baseada em trnH-psbA. Valores nos nós representam as probabilidades posteriores. ${ }^{1}$ Espécime coletado no presente trabalho; ${ }^{2}$ Espécime referido como M. triunca por Chanderbali et al. (2001). 


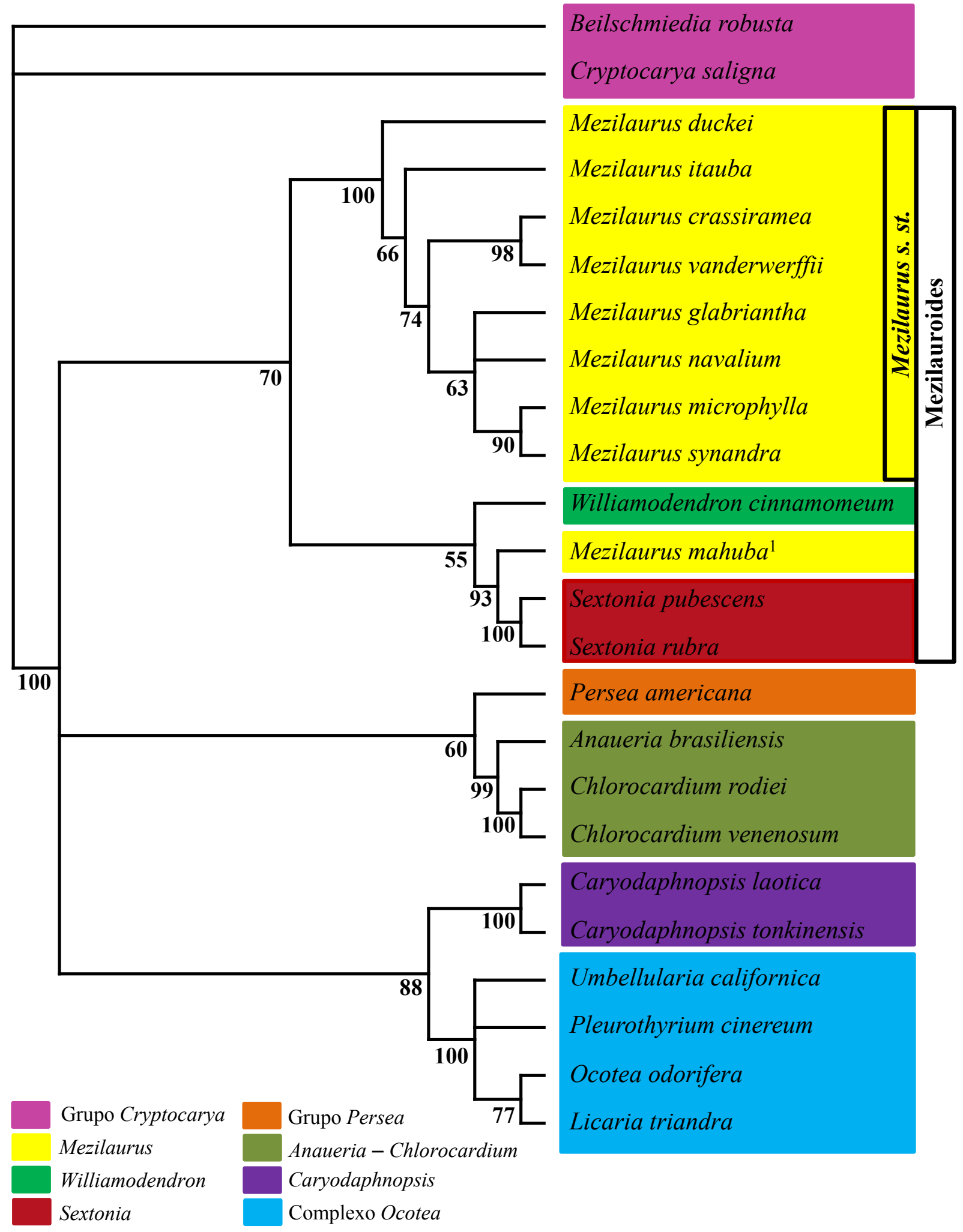

Figura 4: Cladograma de consenso estrito entre os mais parcimoniosos da análise de Parcimônia baseada em ITS. Valores nos nós representam os índices de bootstrap superiores à $50 \%$. Análise com índice de consistência (IC) $=0,65$ e índice de retenção (IR) $=0,53 .{ }^{1}$ Espécime referido como $M$. triunca por Chanderbali et al. (2001). 


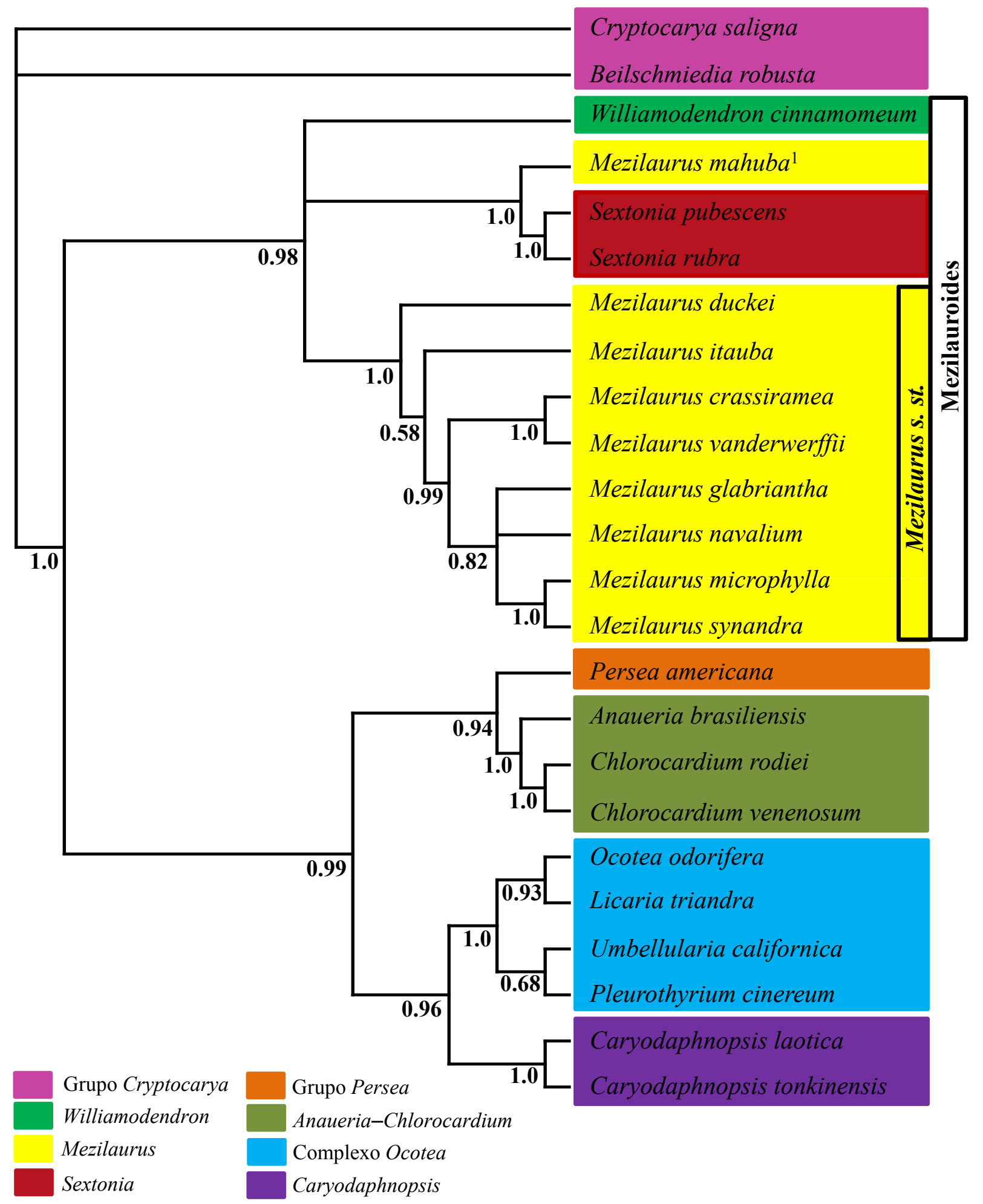

Figura 5: Cladograma de consenso de maioria da análise Bayesiana baseada em ITS. Valores nos nós representam as probabilidades posteriores. ${ }^{1}$ Espécime referido como $M$. triunca por Chanderbali et al. (2001). 


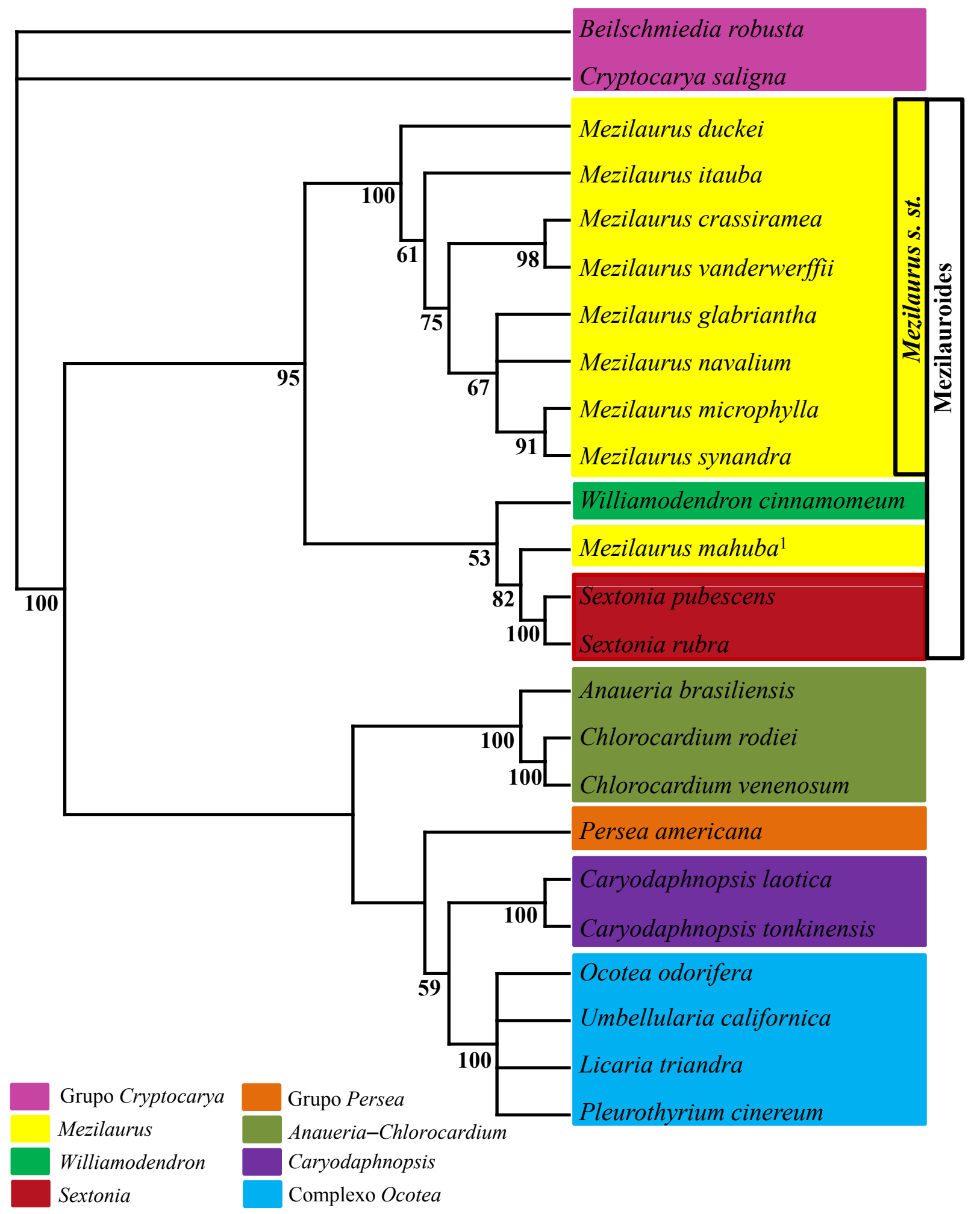

Figura 6: Cladograma de consenso estrito entre os mais parcimoniosos da análise de Parcimônia baseada nos marcadores trnH-psbA e ITS combinados. Valores nos nós representam os índices de bootstrap superiores à $50 \%$. Análise com índice de consistência $(\mathrm{IC})=0,66$ e índice de retenção $(\mathrm{IR})=0,53 .{ }^{1}$ Espécime referido como M. triunca por Chanderbali et al. (2001). 


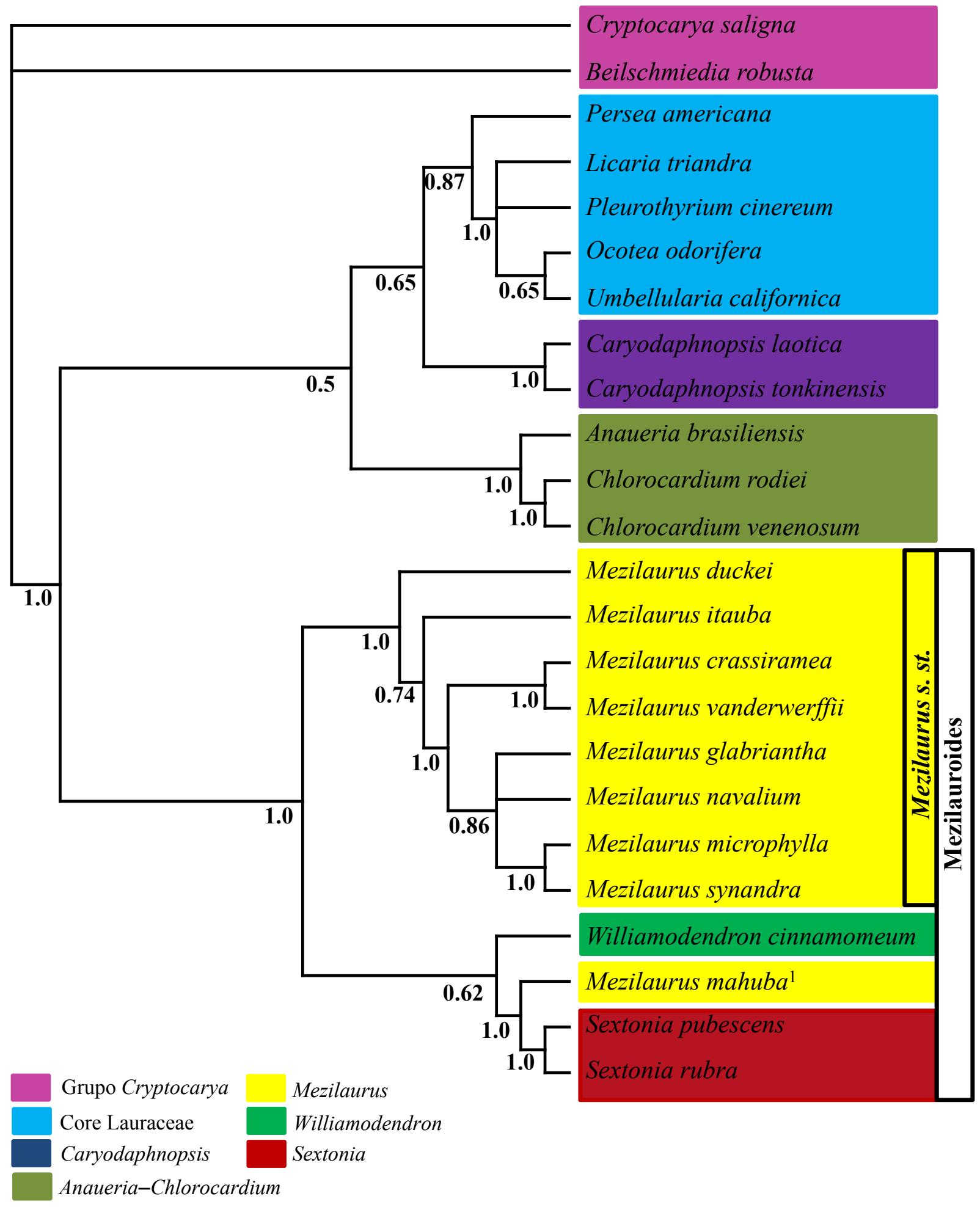

Figura 7: Cladograma de consenso de maioria da análise Bayesiana baseada nos marcadores trnH$p s b A$ e ITS combinados. Valores nos nós representam as probabilidades posteriores. ${ }^{1}$ Espécime referido como M. triunca por Chanderbali et al. (2001). 
"Grupo Mezilaurus"

O monofiletismo do "grupo Mezilaurus", composto pelos clados AnaueriaChlorocardium (gêneros Anaueria e Chlorocardium) e Mezilauroides (gêneros Mezilaurus, Sextonia e Williamodendron), sensu Rohwer \& Rudolph (2005), não foi confirmado em nenhuma das análises (Figuras 2-7). Com a Parcimônia, baseada em sequências de trnH-psbA, ocorreu uma politomia contendo Anaueria, Mezilauroides, Chlorocardium, Caryodaphnopsis e Core Lauraceae (Figura 2). Já na análise Bayesiana com o mesmo marcador, Anaueria emergiu como grupo-irmão do clado (Chlorocardium (Mezilauroides (Caryodaphnopsis (Core Lauraceae)))) (Figura 3).

$\mathrm{Na}$ análise de Parcimônia com ITS, o clado Anaueria-Chlorocardium (Anaueria e Chlorocardium), surgiu como grupo-irmão de Persea. A relação entre Anaueria e Chlorocardium é altamente sustentada, com $99 \%$ de bootstrap (BT), entretanto Persea como grupo-irmão de Anaueria-Chlorocardium tem suporte fraco $(60 \%$ BT). Nessa análise ocorreu uma politomia entre os clados Mezilauroides, (Persea (Anaueria (Chlorocardium))) e (Caryodaphnopsis (complexo Ocotea)) (Figura 4). A análise Bayesiana com o mesmo marcador alcançou resultado bastante semelhante, porém, o clado (Persea (Anaueria (Chlorocardium))) foi grupo-irmão de (Caryodaphnopsis (complexo Ocotea)) (Figura 5), relação com alto suporte, 0,99 de probabilidades posteriores (PP).

Com inferências da Parcimônia, baseadas nos dados dos marcadores combinados, o clado Anaueria-Chlorocardium surgiu como grupo-irmão de (Persea (Caryodaphnopsis (complexo Ocotea))), todavia, essa relação apresentou suporte inferior a $50 \%$ de bootstrap (Figura 6). Na análise Bayesiana com os marcadores combinados, Anaueria-Chlorocardium emergiu como grupo-irmão de (Caryodaphnopsis (Core Lauraceae)), porém, com baixo valor de suporte para essa relação (0,5 PP) (Figura 7). 
Os resultados obtidos demonstraram que o "grupo Mezilaurus" (sensu Rohwer \& Rudolph 2005) não é monofilético, com posicionamento incerto de Chlorocardium e Anaueria. Esse resultado é conflitante com os de Chanderbali et al. (2001) utilizando os marcadores plastidiais trnL-trnF, trnH-psbA, trnT-trnL e rpl16. Nas análises dos autores o "grupo Mezilaurus", representado por Anaueria, Chlorocardium, Mezilaurus e Sextonia, emergiu como clado com alto suporte (até 99\% BT), com o clado Anaueria-Chlorocardium (Anaueria e Chlorocardium) como grupo-irmão do clado Mezilauroides (Mezilaurus e Sextonia). Todavia, quando os autores utilizaram o marcador nuclear ITS, o "grupo Mezilaurus" não apresentou suporte considerável.

Na filogenia de Rohwer \& Rudolph (2005), baseada em sequências de $\operatorname{trnK}$, a relação entre o clado Anaueria-Chlorocardium e os Mezilauroides foi ainda menos clara. Mesmo utilizando todas as espécies conhecidas de Anaueria e Chlorocardium, os autores incluíram apenas uma espécie dos gêneros Mezilaurus, Sextonia e Williamodendron. Como resultado, em diversas de suas análises, os autores encontraram baixo suporte na relação de grupos-irmãos entre os clados Mezilauroides e Anaueria-Chlorocardium. Nas análises 31-47 dos autores, correspondendo à região não codificante da matriz, o "grupo Mezilaurus" não foi suportado como clado, enquanto os três principais subclados, Anaueria, Chlorocardium e os Mezilauroides, formaram uma politomia em que o quarto ramo foi o Core Lauraceae (Rohwer \& Rudolph 2005).

Com exceção de Anaueria (Kostemans 1938a) e Mezilaurus (Allemão 1848), os gêneros dos clados Anaueria-Chlorocardium e Mezilauroides, Chlorocardium (Rohwer et al. 1991), Sextonia (van der Werff 1997) e Williamodendron (Kubitzki \& Richter 1987), foram descritos há menos de 25 anos. Portanto, considerando os sistemas de classificações tradicionais, as características morfológicas utilizadas seriam insuficientes para considerar estes gêneros como próximos (Tabela 6). Por este motivo, nenhum autor propôs no passado algum tipo de proximidade filogenética dessas espécies (e.g Meissner 1864; Bentham \& Hooker 1880; Mez 1889; Pax 1889; Kostermans 1957; Hutchinson 1964) 
Porém, na classificação de Rohwer (1993a), o autor fez agrupamentos informais, colocando Anaueria, Mezilaurus e Williamodendron no "grupo Ocotea", "subgrupo Mezilaurus". Segundo o autor, o "subgrupo Mezilaurus" é caracterizado por estames com locelos mais ou menos apicais e fruto com uma cúpula pateliforme.

O clado Anaueria-Chlorocardium (Anaueria e Chlorocardium) compartilha as folhas opostas e crescimento contínuo nos ramos, ao passo que o clado Mezilauroides (Mezilaurus, Sextonia e Williamodendron) apresenta folhas congestas no ápice dos ramos, resultado de seu crescimento rítmico apositivo (Tabela 6).

Anaueria, por possuir flores com seis estames férteis, anteras biloceladas, glândulas ausentes, estaminódios presentes na série IV do androceu, cúpula discoide e pedicelo lenhoso (Rohwer 1993a), foi incluído em Beilschmiedia por Kostermans 1957. Por outro lado, utilizando características anatômicas, Richter (1981) sugeriu próxima relação entre Anaueria e Mezilaurus, enquanto Kostermans (1938a) indicaou semelhança entre os gêneros, baseado na persistência das tépalas na cúpula.

Chlorocardium foi considerado parte de Nectandra Rol. ex Rottb. ou Ocotea Aubl., até ser avaliado como um gênero independente por Rohwer et al. (1991). Chlorocardium, por apresentar características não usuais para a família (flores com 4-10 tépalas, 12-20 estames, todos com glândulas e ausência de células secretoras no xilema secundário), foi tratado como genera incertae sedis na classificação de Rohwer (1993a) e reconhecido com isolada posição dentro da família baseado na anatomia da madeira (Record \& Hess 1942).

Os resultados baseados nos dados das análises de ITS e combinado entre os marcadores evidenciaram não confirmaram os resultados de Chanderbali et al. (2001), com o monofiletismo do "grupo Mezilaurus". Todavia, o presente trabalho confirma Anaueria e Chlorocardium como gêneros fortemente relacionados e os clados Mezilauroides e Anaueria-Chlorocardium como distintos. Esse resultado foi confirmado por dados previamente publicados (Chanderbali et al. 
2001; Rohwer \& Rudolph 2005), entretanto a posição de do clado Anaueria-Chlorocardium entre os demais de Lauraceae continua sem sustentação e incerta dentro da família. Contudo, o clado Mezilauroides (sensu Rohwer \& Rudolph 2005) emergiu em todas as análises, assim como em filogenias moleculares precedentes (Chanderbali et al. 2001; Rohwer \& Rudolph 2005).

\section{Clado Mezilauroides}

Os Mezilauroides sensu Rohwer \& Rudolph (2005), composto pelos gêneros Mezilaurus, Sextonia e Williamodendron, emergiu como monofilético com suporte baixo na análise de parcimônia com ITS (Figura 4), moderado na parcimônia com trnH-psbA (Figura 2) e alto em todas as análises bayesianas (Figuras 3, 5 e 7) e de parcimônia com dados combinados (Figura 6). Nas análises de Parcimônia com trnH-psbA e ITS separadamente, as relações de Mezilauroides com outros clados permaneceram incertas, uma vez que este apareceu em uma politomia nas árvores de consenso estrito (Figuras 2 e 4). Entretanto, na inferência Bayesiana com trnH-psbA, o clado Mezilauroides foi grupo-irmão de (Caryodaphnopsis (Core Lauraceae)) (Figura 3), enquanto com ITS foi grupo-irmão do clado (Persea (Anaueria-Chlorocardium)) (Caryodaphnopsis (complexo Ocotea))) (Figura 5).

Com a análise de Parcimônia, combinada entre os marcadores, o clado Mezilauroides apareceu como irmão do clado (Anaueria-Chlorocardium (Persea (Caryodaphnopsis (complexo Ocotea)))), apesar de esta relação ser suportada por bootstrap inferior a 50\% (Figura 6). Com os marcadores combinados na análise Bayesiana o resultado foi bastante semelhante ao da Parcimônia, com Mezilauroides como grupo-irmão do clado (Anaueria-Chlorocardium (Caryodaphnopsis (Core Lauraceae))) (Figura 7). 
Tabela 6: Clados constituintes do "grupo Mezilaurus" sensu Rohwer \& Rudolph (2005), seus respectivos gêneros e características morfológicas diagnósticas.

\begin{tabular}{|c|c|c|c|c|c|c|c|c|}
\hline Clado & Gênero & Filotaxia & $\begin{array}{c}\text { Crescimento } \\
\text { dos ramos }\end{array}$ & $\begin{array}{l}\text { Estames } \\
\text { férteis } \\
\text { por flor }\end{array}$ & $\begin{array}{c}\text { Série } \\
\text { fértil do } \\
\text { androceu }\end{array}$ & $\begin{array}{c}\text { Glândulas } \\
\text { na série III } \\
\text { do } \\
\text { androceu }\end{array}$ & $\begin{array}{l}\text { Tépalas na } \\
\text { cúpula }\end{array}$ & Cúpula \\
\hline
\end{tabular}

Anaueria oposta continuo 6 I e II - persistentes pateliforme a plana

Anaueria-Chlorocardium

\begin{tabular}{|c|c|c|c|c|c|c|c|c|}
\hline & Chlorocardium & oposta & contínuo & $12-20$ & $\begin{array}{l}\text { I, II e } \\
\text { III/I, II, } \\
\text { III e IV/I, } \\
\text { II, III, IV } \\
\text { e V }\end{array}$ & presentes & decíduas & cupuliforme \\
\hline \multirow[t]{3}{*}{ Mezilauroides } & Mezilaurus & alternas & rítmico & 3 & III & ausentes & persistentes & pateliforme a plana \\
\hline & Sextonia & alternas & rítmico & 9 & I, II e III & presentes & decíduas & cupuliforme \\
\hline & Williamodendron & alternas & rítmico & 3 & III & ausentes & persistentes & pateliforme a plana \\
\hline
\end{tabular}


Com relação à afinidade entre os terminais do clado Mezilauroides, a análise de Parcimônia realizada com o trnH-psbA indicou relação incerta, evidenciada por uma politomia entre todos os membros do gênero Mezilaurus e o clado com baixo suporte (Williamodendron (Sextonia)) (65\% BT) (Figura 2). Na análise Bayesiana realizada com o mesmo marcador, a relação entre os terminais do clado Mezilauroides foi mais bem definida, porém, com uma politomia de (Mezilaurus mahuba, Mezilaurus s. st., (Williamodendron (Sextonia))) (Figura. 3).

Por outro lado, nas análises de Parcimônia baseadas em ITS e com os dados combinados entre os marcadores trnH-psbA+ITS, o clado Mezilauroides está representado por dois subclados: subclado Mezilaurus s. st., constituído pelas espécies do gênero Mezilaurus, excluindo M. mahuba e o subclado Sextonia-Williamodendron, com (Williamodendron (Mezilaurus mahuba (Sextonia))). Nessas análises, o suporte do subclado Mezilaurus s. st. foi máxima (100\% BT), entretanto, o que sustentou Williamodendron no clado com Mezilaurus mahuba e Sextonia foi baixo $(55,53 \%$ BT) (Figuras 4 e 6$)$.

Na análise Bayesiana, utilizando o marcador ITS, ocorreu uma politomia entre Mezilaurus s. st., Williamodendron e (Mezilaurus mahuba (Sextonia)). Nessa análise, Mezilaurus s. st. e (Mezilaurus mahuba (Sextonia)) receberam alto suporte (1,0 PP) (Figura 5). Porém, com os dados combinados, foi verificado dois subclados dentro do clado Mezilauroides: Mezilaurus s. st. (1,0 PP), constituído pelas espécies do gênero Mezilaurus, excluindo M. mahuba e o subclado Sextonia-Williamodendron com (Williamodendron (Mezilaurus mahuba (Sextonia))) (0,62 PP) (Figura 7).

Esses resultados são semelhantes aos encontrados por Chanderbali et al. (2001) e Rohwer \& Rudolph (2005). Segundo Chanderbali et al. (2001), Mezilaurus e Sextonia formam um clado com alto suporte, enquanto para Rohwer \& Rudolph (2005), elevado suporte ocorreu para o clado composto pelos gêneros Mezilaurus, Sextonia e Williamodendron. 
O clado Mezilauroides apresenta como provável sinapomorfia a presença de folhas congestas no ápice dos ramos como produto de seu crescimento rítmico apositivo. Rohwer et al. (1991) e van der Werff (1997), também reconheceram semelhança morfológica entre Sextonia e Mezilaurus, considerando a posição de suas folhas, enquanto essa característica foi utilizada por Vicentini et al. (1999) para identificar Mezilaurus, Sextonia e Williamodendron dentro de Lauraceae.

Entretanto, levando em consideração características tradicionalmente utilizadas na taxonomia de Lauraceae, Sextonia com nove estames férteis por flor, representando as séries I, II e III do androceu, anteras tetraloceladas, fruto com cúpula envolvendo de $1 / 5-1 / 3$ do fruto e tépalas decíduas, não apresenta atributos morfológicos para ser considerado próximo a Mezilaurus ou Williamodendron (e.g Meissner 1864; Bentham \& Hooker 1880; Mez 1889; Pax 1889; Kostermans 1957; Hutchinson 1964) (Tabela 6). Por essa razão, Sextonia foi tratado como Ocotea ou Nectandra (Mez 1889; Allen 1963) até ser descrito como um gênero por van der Werff (1997).

Por outro lado, Mezilaurus e Williamodendron compartilham, entre outras características, a presença de três estames férteis por flor, representando a série III do androceu e cúpula bastante reduzida, de pateliforme à plana com tépalas persistentes (Tabela 6). Apesar disso, Williamodendron foi criado baseado em duas espécies com anteras tetraloceladas tratadas por van der Werff (1987) como Mezilaurus (Kubitzki \& Richter 1987). Consequentemente, os dois gêneros foram considerados próximos na classificação de Rohwer (1993a), fazendo parte do “subgrupo Mezilaurus". As principais diferenças entre os gêneros é a presença de inflorescências do tipo duplo racemo (dibótrio) e estames com anteras biloceladas em Mezilaurus, inflorescências tirsoide-paniculadas e anteras tetraloceladas em Williamodendron.

Segundo a atual circunscrição de cada gênero dentro do clado Mezilauroides e baseado nas análises com ITS e trnH-psbA+ITS, Mezilaurus foi o único que pode ser confirmado como 
não monofilético e M. mahuba emergiu como grupo-irmão de Sextonia (Figuras 4-7). Por essa razão, os resultados do presente trabalho são conflitantes com o conceito de Mezilaurus adotado por van der Werff (1987). O autor considerou em Mezilaurus, espécies que compartilhavam folhas congestas na extremidade dos ramos, três estames férteis por flor, anteras biloceladas ou tetraloceladas e fruto com cúpula de pateliforme a plana. Por outro lado, o presente trabalho, corrobora a manutenção de Mezilaurus segundo o conceito de Kostermans (1938c), com espécies com três estames férteis, anteras biloceladas, eretas, ausência de glândulas nas flores e cúpula de pateliforme a plana com tépalas persistentes.

\section{Clado Mezilaurus s. st.}

O clado Mezilaurus s. st. nas análises, compreendeu todas as espécies do gênero Mezilaurus, exceto M. mahuba. Na análise de Parcimônia com trnH-psbA, as relações do clado Mezilaurus s. st., permaneceram incertas, uma vez que este clado apareceu em uma politomia nas árvores de consenso (Figura 2). Entretanto, na inferência Bayesiana com o mesmo marcador ou nas análises de Parcimônia e Bayesiana com ITS e com os marcadores combinados, Mezilaurus s. st. emergiu como um clado com alto suporte (100\% BT e 1,0 PP) (Figuras 3-7). As afinidades entre os membros do clado só foram observadas nas análises com ITS e os marcadores combinados, cuja discussão abaixo está de acordo com essas inferências (Figuras 4-7).

A presença de sinapomorfias morfológicas no clado Mezilaurus s. st. ainda é incerta. O clado pode ser definido, morfologicamente dentro de Mezilauroides, pela combinação da presença de três estames férteis, representando a III série do androceu, anteras biloceladas, eretas, ausência de glândulas e fruto com cúpula pateliforme a plana com tépalas persistentes.

Mezilaurus duckei é o táxon-irmão do restante das espécies de Mezilaurus s. st. As análises demonstraram que suas prováveis autopomorfias são a presença de inflorescências do 
tipo duplo racemo (dibótrio) com ramos laterais não umbeliformes e seis estaminódios, presentes nas séries I e II do androceu. Apesar de M. thoroflora van der Werff não ter sido incluída na análise, é possível que forme um clado com M. duckei, como grupo-irmão do restante de Mezilaurus s. st., já que compartilha suas prováveis autopomorfias. Este clado inclui as espécies de Mezilaurus s. st. com nove estaminódios, representando as séries I, II e IV do androceu.

Portanto, as espécies do clado composto por $M$. duckei e possivelmente M. thoroflora, podem ser identificadas dentro de Mezilaurus s. st., pela combinação das seguintes características: inflorescências do tipo duplo racemo (dibótrio) com ramos laterais não umbeliformes, bractéolas persistentes, presença de nove estaminódios, representando as séries I, II e IV do androceu e lâminas foliares pubérulas na face abaxial. O clado apresenta distribuição geográfica na região Amazônica, com Mezilaurus duckei endêmica da região norte do Brasil, estado do Amazonas, enquanto M. thoroflora ocorre somente no norte da Guiana.

O clado representado por (M. itauba (Mezilaurus crassiramea (M. vanderwerffii)) (M. glabriantha, M. navalium, (M. microphylla (M. synandra)))) apresentou baixo suporte de sustentação (Figuras 4-7) e possui como prováveis sinapomorfias a presença de inflorescências do tipo duplo racemo (dibótrio) com ramos laterais umbeliformes e as bractéolas decíduas. Em Mezilaurus crassiramea ocorreu provável reversão para as inflorescências do tipo duplo racemo (dibótrio) com ramos laterais não umbeliformes e bractéolas persistentes.

O clado pode ser definido morfologicamente dentro de Mezilaurus s. st., pela ausência de ciclos completos de estaminódios. Os estaminódios podem estar totalmente ausentes em $M$. navalium e M. microphylla ou, raramente ocorrendo somente um estaminódio por flor em $M$. crassiramea, M. glabriantha, M. itauba e M. vanderwerffii.

Portanto, a presença das inflorescências do tipo duplo racemo (dibótrio) com ramos laterais não umbeliformes e tépalas persistentes teve uma provável origem independente em $M$. duckei (M. thoroflora?) e em M. crassiramea. Por outro lado, a presença de ciclos completos de 
estaminódios nas séries I e II apresenta somente uma origem dentro de Mezilaurus s. st., em M. duckei e possivelmente $M$. thoroflora.

Mezilaurus itauba é irmã do clado ((Mezilaurus crassiramea (M. vanderwerffii)) (M. glabriantha, M. navalium, (M. microphylla (M. synandra)))), aqui intitulado como core Mezilaurus (Figura 8). Todavia, a relação de M. itauba com o core Mezilaurus apresentou baixo suporte em todas as análises (Figuras 4-7). A espécie é difícil de ser definida, caracterizada por uma grande combinação de caracteres e apresenta ampla distribuição geográfica, ocorrendo em praticamente toda extensão da Amazônia.

O core Mezilaurus, composto por ((Mezilaurus crassiramea (M. vanderwerffii)) (M. glabriantha, M. navalium, (M. microphylla (M. synandra)))) apresentou baixo suporte nas análises de Parcimônia baseada em ITS e os marcadores combinados (74 e 75\% BT) (Figuras 4 e 6), porém, robusto nas inferências Bayesianas (0,99 e 1,0 PP) (Figuras 5 e 7). A relação dentro do clado foi observada com (Mezilaurus crassiramea (M. vanderwerffii)) emergindo como grupoirmão do clado (M. glabriantha, M. navalium, (M. microphylla (M. synandra))). O core Mezilaurus não apresenta nenhuma espécie com distribuição restrita à Amazônia, basicamente com Mezilaurus crassiramea e M. synandra apresentando ampla distribuição, $M$. vanderwerffii e M. microphylla características de regiões do Cerrado brasileiro e M. glabriantha e M. navalium da Floresta Atlântica.

Mezilaurus crassiramea e M. vanderwerffii formaram um subclado dentro do core Mezilaurus com suporte elevado em todas as análises com ITS e os marcadores combinados (Figuras 4-7), no entanto, morfologicamente não foi possível detectar possíveis sinapomorfias. As duas espécies diferenciam-se principalmente pela estrutura do indumento foliar e características das inflorescências. 


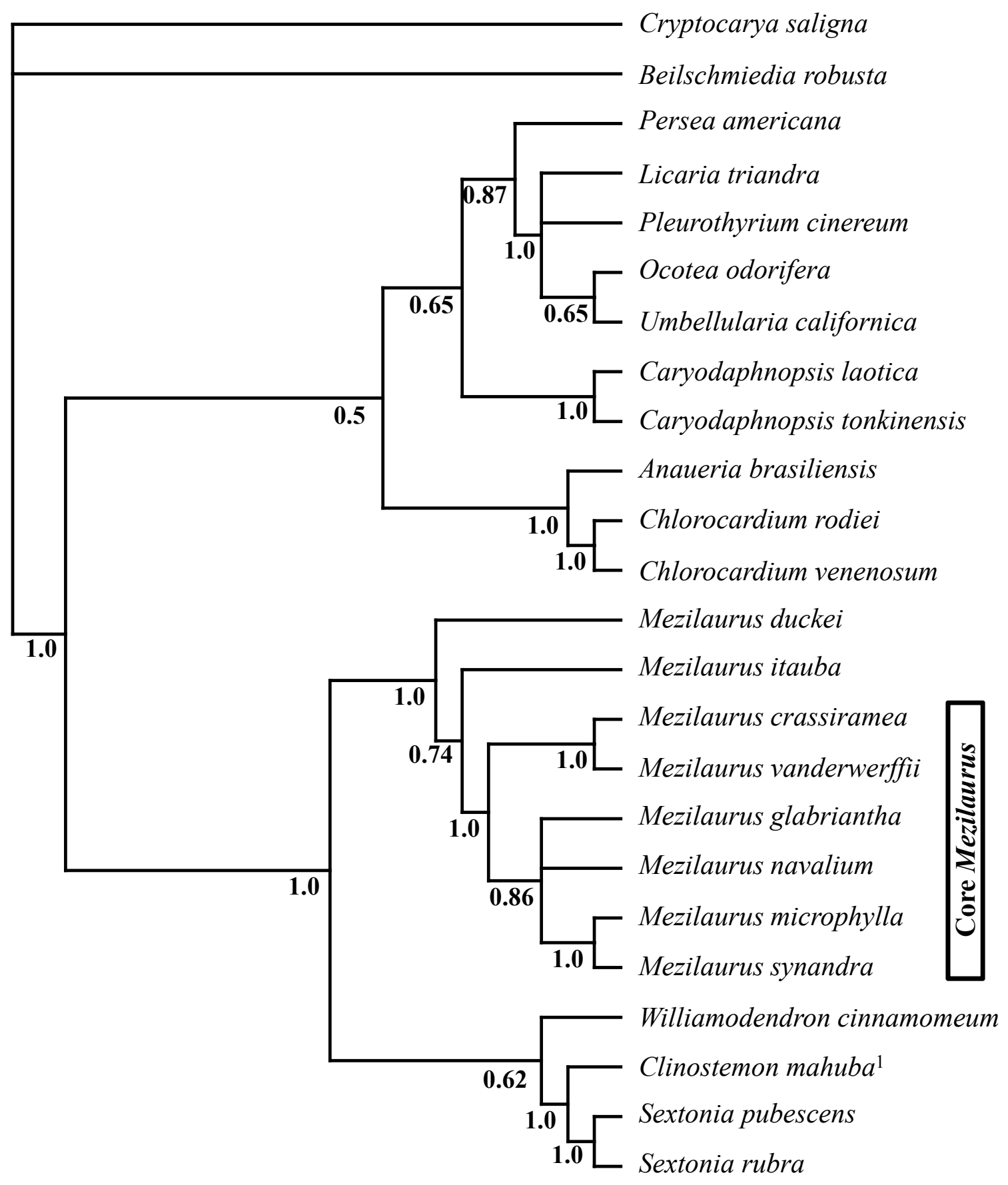

Figura 8: Cladograma de consenso de maioria da análise Bayesiana baseada nos marcadores trnHpsbA e ITS combinados. O cladograma indica o restabelecimento de Clinostemon e a presença do core Mezilaurus. Valores nos nós representam as probabilidades posteriores. ${ }^{1}$ Espécime referido como M. triunca por Chanderbali et al. (2001). 
Mezilaurus crassiramea apresenta folhas com face abaxial hirsuta, vilosa a lanosa, inflorescências do tipo duplo racemo (dibótrio) com ramos laterais não umbeliformes e bractéolas persistentes, enquanto $M$. vanderwerffii possui folhas com face abaxial glabra a subglabra, inflorescências do tipo duplo racemo (dibótrio) com ramos laterais umbeliformes e bractéolas decíduas. Mezilaurus crassiramea apresenta a mais ampla distribuição do gênero, ocorrendo no Brasil, Guiana e Venezuela. No Brasil, a espécie ocorre na Amazônia, Cerrado e Floresta Atlântica. Mezilaurus vanderwerffii apresenta distribuição restrita ao Brasil, correndo no Cerrado, floresta estacional e na transição entre essas duas formações do Pantanal matogrossense e sulmatogrossense e seu entorno nos estados do Mato Grosso e Mato Grosso do Sul. As duas espécies são simpátricas em algumas regiões nesses estados.

O outro subclado dentro do core Mezilaurus (M. glabriantha, M. navalium ( $M$. microphylla (M. synandra))) apresenta distribuição exclusiva no Brasil e emergiu em todas as análises com ITS e os marcadores combinados. Todavia, o clado recebeu baixo suporte nas análises de Parcimônia (63 e 67\% BT) (Figuras 4 e 6) e moderados nas Bayesianas (0,82 e 0,86 PP) (Figuras 5 e 7). A relação total dentro do clado não foi elucidada uma vez que foi obtida uma politomia nos cladogramas entre Mezilaurus glabriantha, M. navalium e (M. microphylla (M. synandra)) (Figuras 4-7).

Das três espécies de Mezilaurus endêmicas da Floresta Atlântica (reconhecidas na revisão taxonômica do presente trabalho), M. glabriantha e M. navalium foram as representantes nas análises. Mezilaurus navalium é a espécie-tipo do gênero e suas relações dentro do clado não puderam ser evidenciadas (Figuras 4-7). A espécie é endêmica do estado do Rio de Janeiro no Brasil, caracterizada por lâminas foliares elípticas, estreito-elípticas a oblanceoladas, representando $4-15 \%$ da folha, receptáculo internamente pubescente a pubérulo e estames com filetes pubescentes. Já Mezilaurus glabriantha apresenta lâminas foliares elípticas a obovadas, 
pecíolos representando 9-16\% da folha, receptáculo internamente glabro e estames com filetes glabros.

Relação com elevado suporte em todas as análises com ITS e os marcadores combinados, dentro desse clado, foi observada entre Mezilaurus microphylla e M. synandra (Figuras 4-7). As duas espécies compartilham a presença de flores depressas com tépalas do mesmo tamanho do receptáculo, ca. $1 / 2$ do comprimento da flor. Mezilaurus synandra apresenta, porém, inflorescências e flores pubérulas, enquanto em M. microphylla estas estruturas são glabras. Mezilaurus microphylla é restrita a um Cerrado no Brasil central, enquanto Mezilaurus synandra ocorre na Amazônia, Cerrado do Brasil central e na Floresta Atlântica do município de Una, sul da Bahia.

Mezilaurus synandra foi a espécie com ocorrência na Amazônia mais próxima filogeneticamente das espécies endêmicas da Floresta Atlântica. Segundo Thomas et al. (1998), 7,4\% das espécies que ocorrem em Una na Bahia são disjuntas entre a região e a Amazônia e $28,1 \%$ endêmicas às florestas da Bahia e Espírito Santo. Em particular interesse é a região do sul da Bahia e norte do Espírito Santo, que possuem uma alta proporção de espécies amazônicas (Rizzini 1967; Andrade-Lima 1973; Prance 1979; Mori et al. 1981). Por esse motivo, de acordo com Langenheim et al. (1973) essa região pode ser chamada de "Hylaea Bahiana"e, gêneros representados por muitas espécies na Amazônia, possuem poucas espécies na Floresta Atlântica.

\section{Clado Sextonia-Williamodendron}

$\mathrm{Na}$ análise de Parcimônia e Bayesiana, baseada em trnH-psbA, Sextonia e Williamodendron formaram um clado (65\% BT; 0,93 PP) (Figuras 2 e 3). Entretanto, nas inferências de Parcimônia com ITS e os marcadores combinados, essa relação foi bastante 
diferente, (Williamodendron (Mezilaurus mahuba (Sextonia))) e com baixo suporte (55, 53\% BT) (Figuras 4 e 6 ).

Na análise Bayesiana com ITS, a relação deste clado não foi evidenciada, formando-se uma politomia nos cladogramas de consenso com (Mezilaurus s. st., Williamodendron, (Mezilaurus mahuba (Sextonia))) (Figura 5). Todavia, com os marcadores combinados a relação foi demonstrada por (Williamodendron (Mezilaurus mahuba (Sextonia))), embora com baixo suporte (0,62 PP) (Figura 7).

Com exceção das análises com trnH-psbA, em todas outras filogenias, (Mezilaurus mahuba (Sextonia)) surgiu como um clado com elevado suporte (93 e 82\% BT; 1,0 PP) (Figuras 4-7). Esse resultado foi confirmado com altos índices de suporte também pelas filogenias de Chanderbali et al. (2001) e Rohwer \& Rudolph (2005). Segundo Chanderbali et al. (2001), Mezilaurus mahuba (como M. triunca) e Sextonia foram grupos-irmãos, enquanto no trabalho de Rohwer \& Rudolph (2005), essa relação foi encontrada entre Sextonia e Williamodendron. Todavia, o clado Sextonia-Williamodendron apresenta pouco em comum levando em consideração características florais (Tabela 6).

Chanderbali et al. (2001) também encontraram suporte elevado (100\% BT) na relação entre Mezilaurus mahuba (tradada como M. triunca) e Sextonia. A proximidade entre os dois gêneros é amparada por dados moleculares e compartilhada pela provável sinapomorfia da presença de um par de glândulas nos estames da série III do androceu. No entanto, esta característica se apresenta paralelamente em outros gêneros de Lauraceae (ver Rohwer 1993b).

Mezilaurus mahuba possui como prováveis autopomorfias os estames com anteras recurvadas e presença de estaminódios nas séries I e II do androceu. Por outro lado, as possíveis sinapomorfias das espécies de Sextonia são a presença de estames da série I e II férteis, anteras tetralocelados e tépalas decíduas na cúpula. Williamodendron possui como provável sinapomorfia a presença de deiscência apical. 
Relação próxima entre Williamodendron e Mezilaurus mahuba (como Clinostemon), baseada em características morfológicas, foi sugerida por Kubitzki \& Richter (1987) e van der Werff (1991). Segundo os autores, Williamodendron apresenta inflorescência monotélica e anteras tetraloceladas, ao passo que em Mezilaurus mahuba (como Clinostemon) a inflorescência é politélica e as anteras biloceladas.

\section{Implicações para taxonomia}

Como relatado acima, as relações dentro do clado Mezilauroides não apoiaram o monofiletismo do gênero Mezilaurus, com uma de suas espécies, M. mahuba, mais próxima filogeneticamente de Sextonia.

Existem algumas opções para se resolver esse problema considerando os clados que emergiram como monofiléticos nas análises. A primeira alternativa seria considerar todo o clado Mezilauroides como somente um gênero, Mezilaurus. A segunda seria considerar Mezilaurus s. st. como um gênero, Williamodendron como outro e Sextonia e Mezilaurus mahuba como um terceiro gênero. Por fim, a terceira opção seria entender os clados Mezilaurus s. st., Williamodendron, Sextonia e Mezilaurus mahuba como gêneros independentes. Esta última opção implicaria no reconhecimento de Mezilaurus mahuba como pertencendo a um gênero à parte.

Mezilaurus mahuba foi descrita como Acrodiclidium mahuba por Sampaio (1917). Kuhlmann \& Sampaio (1928) propuseram Clinostemon, baseado em A. mahuba, pela presença de anteras encurvadas, um par de glândulas nos filetes e nove estaminódios, pertencentes às séries I, II e IV do androceu. Separado

Kostermans (1938c), não aceitou o novo gênero, alegando que o arqueamento das anteras de $A$. mahuba não era suficiente para considerar como um gênero à parte, transferindo esta 
espécie para Licaria. Lundell (1969) também não aceitou a espécie em Licaria e transferiu $A$. mahuba para Misanteca.

Kubitzki et al. (1979), baseando-se em dados morfológicos e de anatomia da madeira, restabeleceram Clinostemon. Segundo os autores, a principal característica que separa Clinostemon seria a presença de estaminódios, os quais estão ausentes em Mezilaurus. Entretanto, van der Werff (1987) não aceitou que tais características seriam suficientes para separar Clinostemon e Mezilaurus como gêneros independentes, realizando a sinonimização e a nova combinação para Mezilaurus mahuba (A. Samp.) van der Werff, sugerindo que a espécie teria uma posição isolada dentro do gênero.

A segunda alternativa apresentada anteriormente, de inclusão de M. mahuba em Sextonia, implicaria no reconhecimento de um gênero bastante variável morfologicamente, uma vez que Sextonia, porém, possui nove estames férteis, pertencentes às séries I, II e III do androceu, anteras tetralocelados e fruto com cúpula cupuliforme, ao passo que $M$. mahuba apresenta três estames férteis, pertencentes à série III do androceu, com um par de glândulas, anteras biloceladas e encurvadas, nove estaminódios, pertencentes às séries I, II e IV do androceu e fruto com cúpula de pateliforme a plana com tépalas persistentes.

Tais características, de uma forma geral, são bastante constantes nos gêneros de Lauraceae e Sextonia s.l. representaria um elemento discrepante neste sentido. Por este motivo, nenhum autor propôs no passado a sinonimização destes gêneros, ou sequer algum tipo de proximidade filogenética de suas espécies (Kostermans 1938c; Kostermans 1957; van der Werff 1987; Rohwer 1993a; van der Werff \& Richter 1996; van der Werff 1997).

Além disso, se a opção fosse sinonimizar os gêneros, Clinostemon teria prioridade e as espécies de Sextonia precisariam de novas combinações. Portanto, Clinostemon, com uma única espécie, C. mahuba, é aqui aceito (Figura 8), apesar de ser monotípico, pois desta forma, a 
estabilidade na classificação é maximizada, além de - o que é ainda mais importante - serem mantidos grupos morfologicamente coerentes (Tabela 7).

Tabela 7: Principais características morfológicas diagnósticas dos gêneros do clado Mezilauroides, com o restabelecimento de Clinostemon.

\begin{tabular}{cccccccc}
\hline Gênero & $\begin{array}{c}\mathrm{N}^{\circ} \\
\text { estames } \\
\text { férteis } \\
\text { por flor }\end{array}$ & $\begin{array}{c}\text { Série fértil } \\
\text { do } \\
\text { androceu }\end{array}$ & $\begin{array}{c}\text { Posição } \\
\text { das anteras }\end{array}$ & $\begin{array}{c}\text { Glândulas } \\
\text { na base dos } \\
\text { estames da } \\
\text { série III }\end{array}$ & Tépalas & Cúpula \\
\hline Clinostemon & 3 & III & encurvadas & presentes & persistentes & $\begin{array}{c}\text { pateliforme a } \\
\text { plana } \\
\text { pateliforme a } \\
\text { plana }\end{array}$ \\
Mezilaurus & 3 & III & eretas & ausentes & persistentes & $\begin{array}{c}\text { plana } \\
\text { Sextonia }\end{array}$ \\
Williamodendron & 3 & I, II e III & eretas & presentes & decíduas & $\begin{array}{c}\text { cupuliforme } \\
\text { pateliforme a } \\
\text { plana }\end{array}$ \\
\hline
\end{tabular}

Clinostemon é monoespecífico, representado somente por C. mahuba com ocorrência na Amazônia do Brasil e Peru. O gênero tem representantes arbóreos, folhas congestas na extremidade dos ramos, resultado de seu crescimento rítmico, folhas assimétricas na base, inflorescências do tipo duplo racemo (dibótrio), flores com três estames férteis, anteras biloceladas, encurvadas, um par de glândulas nos filetes (Figura 9, A e B), estaminódios nas séries I, II e IV do androceu e cúpula pateliforme a plana com tépalas persistentes.

Nos neotrópicos, além de Clinostemon, Mezilaurus, Licaria, Mocinnodaphne LoreaHernández, duas espécies de Aiouea e uma de Yasunia van der Werff compartilham flores bissexuadas, três estames férteis e anteras biloceladas. Os gêneros citados, juntamente com Williamodendron (anteras tetraloceladas), são os representantes neotropicais de Lauraceae com três estames férteis. 

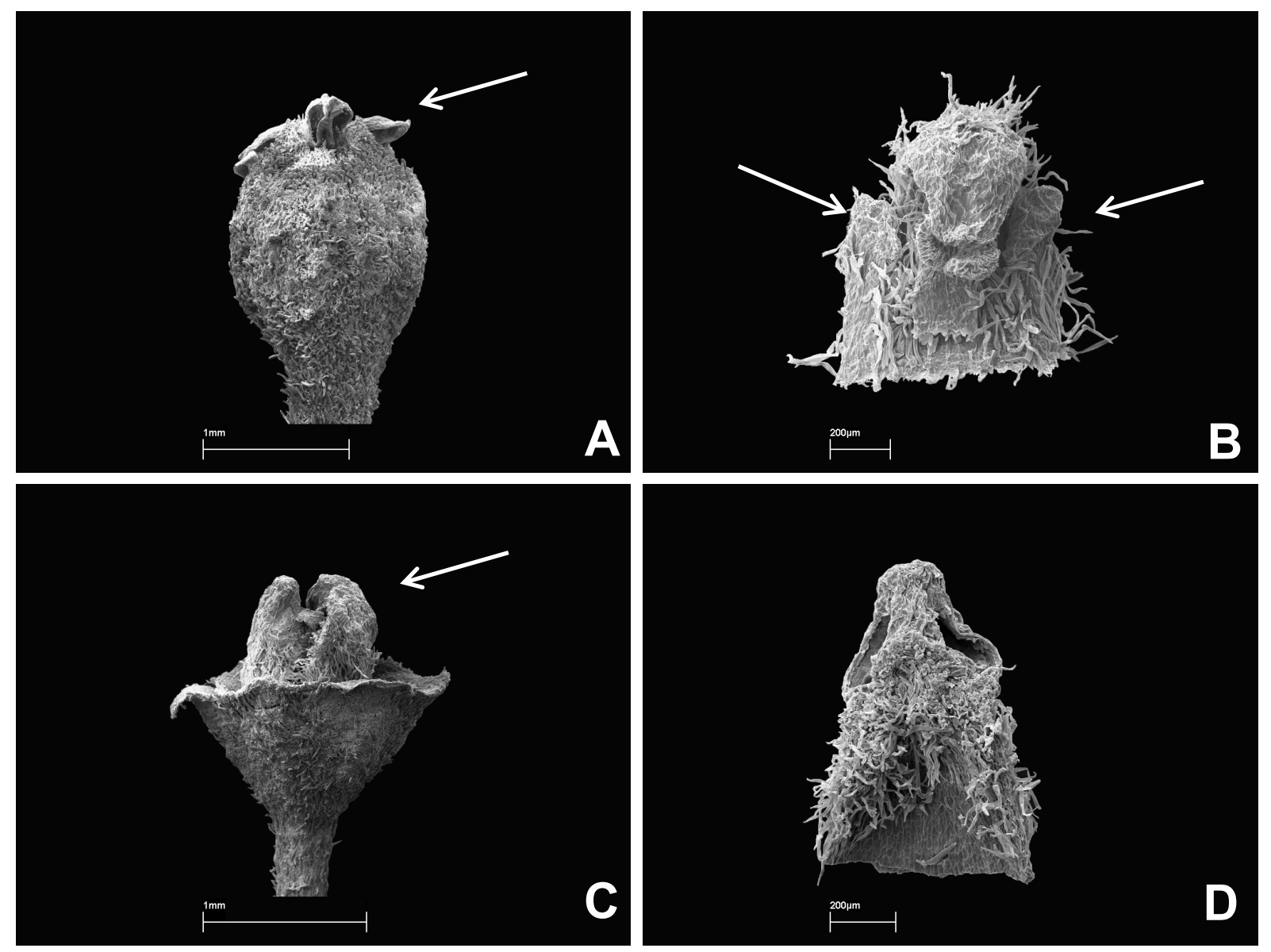

Figura 9: Características diagnósticas de Clinostemon e Mezilaurus. A-B. Clinostemon mahuba. A: flor com detalhe (seta) dos estames com anteras encurvadas; B: estame com antera encurvada e um par de glândulas no filete (setas) (Krukoff 5870). C-D. Mezilaurus subcordata. C: flor com detalhe (seta) dos estames com anteras eretas; D: estames com anteras eretas e ausência de glândulas (Ferreira et al. 8772). 
Mezilaurus é reconhecido com 15 espécies arbóreas ou arbustivas, folhas congestas na extremidade dos ramos, resultado do seu crescimento rítmico, inflorescências do tipo duplo racemo (dibótrio), flores com três estames férteis, anteras biloceladas, cúpula pateliforme a plana com tépalas persistentes. Mezilaurus diferencia-se de Clinostemon pelas anteras eretas e ausência de glândulas nos filetes (Figura 9). Licaria é representada por cerca de 40 espécies de árvores ou arbustos com crescimento contínuo nos ramos e folhas laxas, inflorescências tirsoidepaniculadas, cúpula cupuliforme com dupla margem (Kurz 2000).

Mocinnodaphne é um gênero monotípico, representado somente por M. cinnamomoidea Lorea-Hernández com crescimento contínuo e folhas laxas nos ramos, folhas triplinervadas, flores com estaminódios da série IV bem desenvolvidos e cúpula com tépalas persistentes (LoreaHernández 1995). Aiouea é representado por cerca de 20 espécies de árvores ou arbustos e seus representantes com três estames férteis e bilocelados são A. myristicoides Mez e A. benthamiana Mez. O gênero apresenta crescimento contínuo (raro rítmico) com folhas laxas nos ramos, inflorescências tirsoide-paniculadas, estames férteis representando a série I do androceu e a cúpula apresenta tépalas frequentemente decíduas (Kubitzki \& Renner 1982; Rohwer 1993a). Yasunia apresenta duas espécies e Y. sessilifolia van der Werff é a representante do gênero com três estames férteis e anteras biloceladas, apresentando também folhas opostas, inflorescências paniculadas, cúpula discoide e tépalas decíduas na cúpula (van der Werff \& Nishida 2010). Já Williamodendron é composto por três espécies com crescimento rítmico e folhas congestas na extremidade dos ramos, inflorescências tirsoide-paniculadas, anteras tetraloceladas e cúpula de pateliforme a plana com tépalas persistentes (Kubitzki \& Richter 1987). A seguir é apresentada uma chave de identificação contendo tais gêneros. 


\section{Chave para os gêneros neotropicais de Lauraceae com três estames férteis}

1. Folhas opostas

Yasunia

1 '. Folhas alternas.

2. Estames com anteras tetraloceladas.

Williamodendron

2'. Estames com anteras biloceladas.

3. Estames férteis representando a série I do androceu; estaminódios presentes na série III.

Aiouea

3'. Estames férteis representando a III série do androceu; estaminódios presentes na série I ou ausentes.

4. Folhas laxamente distribuídas nos ramos; inflorescências monotélicas; cúpula cupuliforme.

5. Folhas peninérveas; cúpula com margem dupla.

Licaria

5'. Folhas triplinervadas; cúpula com margem única Mocinnodaphne

4'. Folhas congestas no ápice dos ramos; inflorescências politélicas; cúpula pateliforme a plana.

6. Base foliar fortemente assimétrica; estames com anteras encurvadas; filetes com um par de glândulas.

Clinostemon

6'. Base foliar simétrica ou raro ligeiramente assimétrica; estames com anteras eretas; filetes sem glândulas.

Mezilaurus 


\subsection{Revisão taxonômica de Mezilaurus Taub. (Lauraceae)}

\section{Tratamento taxonômico}

1. Mezilaurus Taub., Bot. Centralbl. 50: 21. 1892. Silvia Allemão, Opúscula ("Plantas Novas do Brasil”), 1848 (nome ilegítimo), non Silvia Vell., Fl. Flumin 55. 1825. Silvaea Meisn. in DC., Prodr. 15 (1): 84.1864 (nome ilegítimo), non Silvaea Phil., Fl. Atacam. 21. 1860. Mezia Kuntze, Revis. Gen. P1. 2: 573.1891 (nome ilegítimo), non Mezia Schwacke, Nat. Pflanzenfam. 3(4): 58. 1890. Neosilvia Pax in Engler \& Prantl, Nat. Pflanzenfam. Nachtr. 2-4: 174. 1897 (nomem superfluo). Tipo: M. navalium (Allemão) Taub.

Árvores, arvoretas ou arbustos. Ramos com crescimento rítmico apositivo; râmulos pubescentes a pubérulos ou tomentosos no ápice, raramente glabros. Folhas congestas no ápice dos râmulos, alternas, raramente subverticiladas ou opostas a subopostas, peninervadas. Inflorescências do tipo duplo racemo (dibótrio), com ramos laterais umbeliformes ou não umbeliformes, subterminais ou axilares; bractéola na base dos pedicelos 1 ou raramente três, persistentes ou decíduas. Flores bissexuadas, trímeras, pubescentes a pubérulas ou glabras a subglabras. Tépalas 6, duas séries de 3, iguais a desiguais. Estames 3, representando a série III do androceu, livres ou raramente conados; anteras eretas, biloceladas, locelos extrorsos, latrorsos, apical-extrorsos ou raramente introrsos; glândulas ausentes. Estaminódios ausentes, presente somente 1, representando as séries I, II ou IV do androceu ou presente 9, representando as séries I, II e IV do androceu. Pistilo livre do receptáculo, glabro ou raro pubescente; estigma lobado. Fruto baga monospérmica, verde quando imaturo, glauco e atro-purpúreo quando maduro. Cúpula plana a pateliforme, tépalas persistentes. 
Etimologia: Mezilaurus é uma homenagem ao botânico alemão e estudioso da família Lauraceae, Carl Christian Mez (1866-1944) (Stafleu \& Cowan 1981; Umberto-Quattrocchi 2000).

\section{Chave para identificação das espécies de Mezilaurus}

1. Lâminas foliares pubérulas, hirsutas, vilosas ou lanosas na face abaxial; inflorescências do tipo duplo racemo (dibótrio) com ramos laterais não umbeliformes; bractéolas persistentes.

2. Lâminas foliares hirsutas, vilosas ou lanosas na face abaxial; estaminódios ausentes ou raramente um por flor, pertence à série IV do androceu. 1.2. M. crassiramea

2'. Lâminas foliares pubérulas na face abaxial; estaminódios nove por flor, pertencentes às séries I, II e IV do androceu.

3. Estames inclusos na antese; pedicelo na frutificação 1,25-2,5 mm compr.; cúpula com diâmetro maior que o pedicelo na frutificação, 2,5-4,5mm diam. 1.4. M. duckei

3'. Estames exsertos na antese; pedicelo na frutificação 9-13 mm compr.; cúpula com diâmetro menor que o pedicelo na frutificação, 5-6,5mm diam......1.14. M. thoroflora

1'. Lâminas foliares glabras a subglabras na face abaxial; inflorescências do tipo duplo racemo (dibótrio) com ramos laterais umbeliformes, raramente com alguns ramos laterais laxos; bractéolas decíduas.

4. Râmulos glabros no ápice; venação na face adaxial das folhas imersa; pedicelo com três bractéolas na base. 1.1. M. caatingae

4'. Râmulos pubescentes a pubérulos no ápice; venação na face adaxial das folhas impressa a proeminente; pedicelo com uma bractéola na base.

5. Flores glabras a subglabras externamente.

6. Tépalas menores que o receptáculo, $1 /{ }_{3}-1 / 5$ do comprimento das flores.

7. Receptáculo internamente glabro; filetes glabros 1.5. M. glabriantha

7'. Receptáculo internamente pubescente a pubérulo; filetes pubescentes.

8. Lâminas foliares estreito-elípticas a oblanceoladas; 3-8,4 vezes mais longas que largas; Mata Atlântica 1.9. M. navalium

8'. Lâminas foliares elípticas a obovadas, raramente estreito-elípticas; 1,5-3,7 vezes mais longas que largas; Amazônia. 
9. Folhas alternas a subopostas, raro opostas; pedicelo (2,5-) 5-23 mm compr., atingindo 7-20 mm na frutificação; cúpula com diâmetro menor que o pedicelo na frutificação

1.11. M. sprucei

9'. Folhas alternas; pedicelos na flor $0,5-6 \mathrm{~mm}$ compr., atingindo $2-8$ $\mathrm{mm}$ na frutificação; cúpula com diâmetro igual ou maior que o pedicelo na frutificação.

1.7. M. itauba

6'. Tépalas do mesmo tamanho ou maiores que o receptáculo, ca. $1 / 2$ do comprimento das flores, raro ligeiramente menores, mas nunca chegando a $1 / 3$.

10. Anteras introrsas; pedicelos $1 / 2^{-} / 3$ do comprimento das flores..1.6. M. introrsa 10 '.Anteras extrorsas ou latrorsas; pedicelos 1-15 vezes o comprimento das flores.

11. Raque principal da inflorescência glabra a subglabra no ápice.

12. Lâminas foliares estreito-elípticas a oblanceoladas, margem plana; Cerrado 1.8. M. microphylla

12'. Lâminas foliares elípticas a obovadas, frequentemente revolutas; Floresta Atlântica 1.10. M. revolutifolia

11'. Raque principal das inflorescência pubérula no ápice.

13. Pecíolos representando $1-6 \%$ das folhas; pedicelos $1,25-3 \mathrm{~mm}$ compr., pedicelo na frutificação com superfície fissurada; cúpula com diâmetro do mesmo tamanho ou ligeiramente maior que o pedicelo na frutificação.

1.15. M. vanderwerffii

13'. Pecíolos representando $8-17 \%$ das folhas; pedicelo $3,5-9 \mathrm{~mm}$ compr., pedicelo na frutificação com superfície lisa; cúpula com diâmetro menor que o pedicelo na frutificação.......1.11. M. sprucei

5'. Flores pubescentes ou pubérulas externamente.

14. Base foliar obtusa, arredondada ou subcordada; anteras introrsas.

1.12. M. subcordata

14'. Base foliar aguda, cuneada ou decorrente; anteras extrorsas ou latrorsas.

15. Flores depressas; tépalas do mesmo tamanho a maiores que o receptáculo, $1 / 2$ do comprimento das flores; tépalas externas maiores ou do mesmo tamanho que as internas

1.13. M. synandra 
15'. Flores elipsoides, raramente globosas; tépalas menores que o receptáculo, $1 / 3-1 / 5$ do comprimento das flores; tépalas externas menores ou do mesmo tamanho que as internas.

16. Lâminas foliares estreito-elípticas ou oblanceoladas; pecíolo representando $5-8 \%$ da folha; estames conados; ovário pubescente. 1.3. M. decurrens

16’. Lâminas foliares elípticas a obovadas, raro estreito-elípticas ou ovadas; pecíolo representando $5-25 \%$ da folha; estames livres; ovário glabro 1.7. M. itauba

1.1. Mezilaurus caatingae van der Werff, Ann. Missouri Bot. Gard. 74: 159. 1987. Tipo: Brasil. Amazonas, São Felipe, Igarapé Tourí, Rio Negro, 27/09/1952, Froés 28761 (holótipo, MO; isótipo, $\mathrm{RB})$.

(Figura 10).

Árvores ca. $15 \mathrm{~m}$ alt. Ritidoma desconhecido. Râmulos ca. 6,5 mm diâm., cilíndricos, marrom, glabros, com lenticelas conspícuas próximas do ápice; catafilos ovados a lanceolados, ca. $3 \mathrm{~mm}$ compr., amarelos, dourados ou creme, pubescentes com ápice ligeiramente seríceo. Folhas alternas, 10-16,4 × 4,3-6 cm. Lâminas obovadas, 2,6-2,8 vezes mais longas que largas, glabras, base decorrente a cuneada, simétrica, ápice obtuso a arredondado, margem ligeiramente revoluta, principalmente na base, pontuações glandulares na face abaxial, muitas vezes inconspícuas. Venação broquidódroma, 8-15 nervuras por lado, imersas nas faces adaxial e abaxial; nervuras secundárias formando um ângulo de $45-70^{\circ}$ com a primária, juntando com as suprajacentes em ângulos agudos a retos; terciárias reticuladas ou percorrentes, oblíquas. Pecíolo 7-10 × 2-3,5 mm, representando 3-7\% da folha, plano, glabro, base ligeiramente dilatada. Inflorescências do tipo duplo racemo (dibótrio) com ramos laterais umbeliformes, axilares ou próximas do ápice dos ramos, ca. $3 \mathrm{~cm}$, pubérulas. Bractéolas na base dos ramos laterais não vistas, bractéolas na base dos pedicelos 3 , uma maior ca. $0,75 \times 0,5 \mathrm{~mm}$, ovada, ápice agudo, duas menores ca. $0,5 \times 0,5$ 
$\mathrm{mm}$, triangulares, glabras ou com poucos tricomas na base e margem, decíduas. Pedicelo $0,4-0,5$ mm compr., pubérulo, tricomas não papilosos. Flores ca. $2 \mathrm{~mm}$ diâm., ca. $2 \mathrm{~mm}$ compr., cor desconhecida, elipsoides, externamente pubérulas na base, tornando-se glabras a medida que se aproxima do ápice, tricomas não papilosos. Tépalas ligeiramente desiguais, externas menores, ca. $0,25 \times 0,5 \mathrm{~mm}$, internas ca. $0,5 \times 1 \mathrm{~mm}$, ovadas, ápice obtuso a arredondado, margem papilosa, internamente pubescentes na base, menores que o receptáculo, $1 / 3^{-1} / 4$ do comprimento da flor. Estames livres, ca. $1 \times 0,75 \mathrm{~mm}$, ligeiramente exsertos na antese; anteras ca. $0,5 \times 0,5 \mathrm{~mm}$, apical-extrorsas, triangulares, glabras frontalmente, pubescentes no dorso, ligeiramente papilosas; filetes ca. $0,5 \times 0,75 \mathrm{~mm}$, retangulares, do mesmo tamanho das anteras, pubescentes. Estaminódios ausentes. Pistilo ca. 1,2 mm compr., glabro; ovário elipsoide a globoso; estilete ca. 0,6 mm compr., exserto na antese. Receptáculo 1-1,25 $\mathrm{mm}$ compr., glabro a subglabro internamente. Fruto desconhecido.

Distribuição e ecologia: Mezilaurus caatingae é restrita do Brasil, conhecida somente pelo espécime-tipo, coletado no extremo noroeste do estado do Amazonas (Figura 11). A espécie ocorre na sub-região Amazônica, representada somente na província Imerí (Figura 1). A espécie ocorre na vegetação da caatinga amazônica, em solo arenoso a $90 \mathrm{~m}$ de altitude. Segundo Rodrigues (1961), a “caatinga amazônica do Rio Negro" é uma vegetação bastante distinta da caatinga encontrada no nordeste brasileiro, caracterizada por uma vegetação baixa, raquítica e muito densa, geralmente de folhagem esclerosada, persistente, sobre solo arenoso, branco, superúmido e muito pobre.

Fenologia: Coletada com flores em setembro.

Etimologia: O epíteto caatingae é uma referência ao tipo de vegetação onde o espécime-tipo foi coletado, em uma caatinga do Rio Negro. 
Status de conservação: A espécie possui registro de ocorrência apenas para uma localidade e um espécime coletado. Portanto, não há informação segura sobre seu risco de extinção, baseado na distribuição ou status da população. Por essa razão, a espécie deve ser considerada, segundo IUCN (2001), como "Dados Deficientes" (DD). A espécie foi considerada rara por Baitello et al. (2009) e sua área de ocorrência, tratada como importante para conservação da flora brasileira (Kasecker et al. 2009).

Nome popular: Desconhecido.

Importância econômica: A madeira da espécie foi citada pelo coletor como de valor comercial.

Mezilaurus caatingae é caracterizada por seus râmulos glabros, lâminas foliares glabras a subglabras, nervuras imersas em ambas as faces, inflorescências do tipo duplo racemo (dibótrio) com ramos laterais umbeliformes, três bractéolas na base dos pedicelos, tépalas menores que o receptáculo, correspondendo $1 / 3-1 / 4$ do comprimento da flor e ovário glabro.

Mezilaurus caatingae é muito semelhante a $M$. decurrens, principalmente por compartilhar as nervuras na face adaxial imersas. Mezilaurus decurrens apresenta, porém, râmulos pubérulos no ápice, lâminas foliares com margem plana e ápice agudo a obtuso, pecíolo pubérulo, uma bractéola na base dos pedicelos e ovário pubescente.

Vegetativamente, $M$. caatingae apresenta características similares e pode ser confundida a algumas coleções de $M$. itauba. No entanto, esta última espécie possui ramos pubérulos, pecíolo pubérulo e uma bractéola na base dos pedicelos.

Clinostemon mahuba já foi tratada como Mezilaurus, e, assim como M. caatingae apresenta três bractéolas na base de cada pedicelo. Clinostemon mahuba possui, porém, râmulos velutinos a tomentosos, margem foliar plana, base fortemente assimétrica, anteras encurvadas, um par de glândulas nos filetes e nove estaminódios, representando as séries I, II e IV do androceu. 


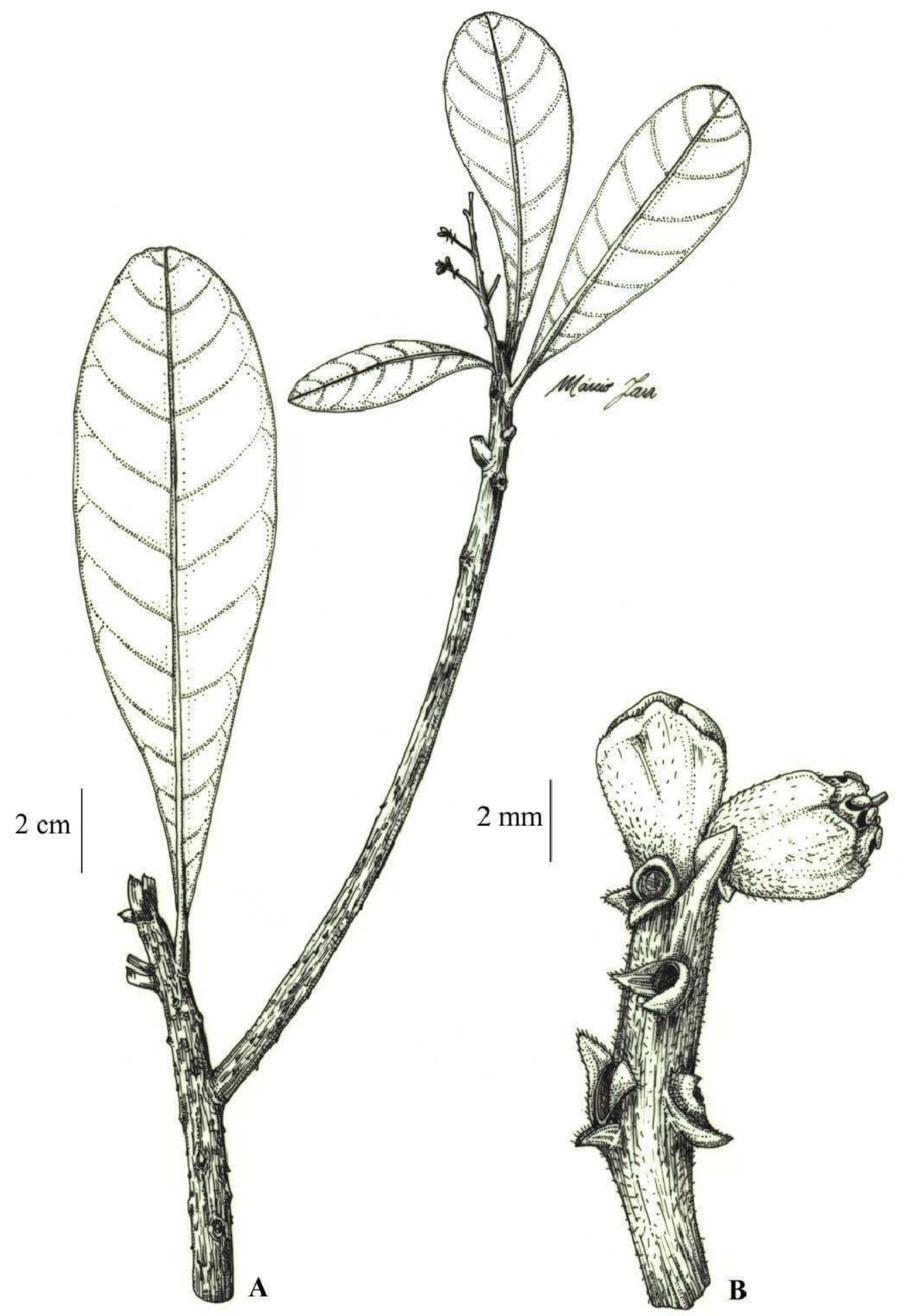

Figura 10: Ilustração de Mezilaurus caatingae. A: ramo com flores; B: detalhe das flores (isótipo). 


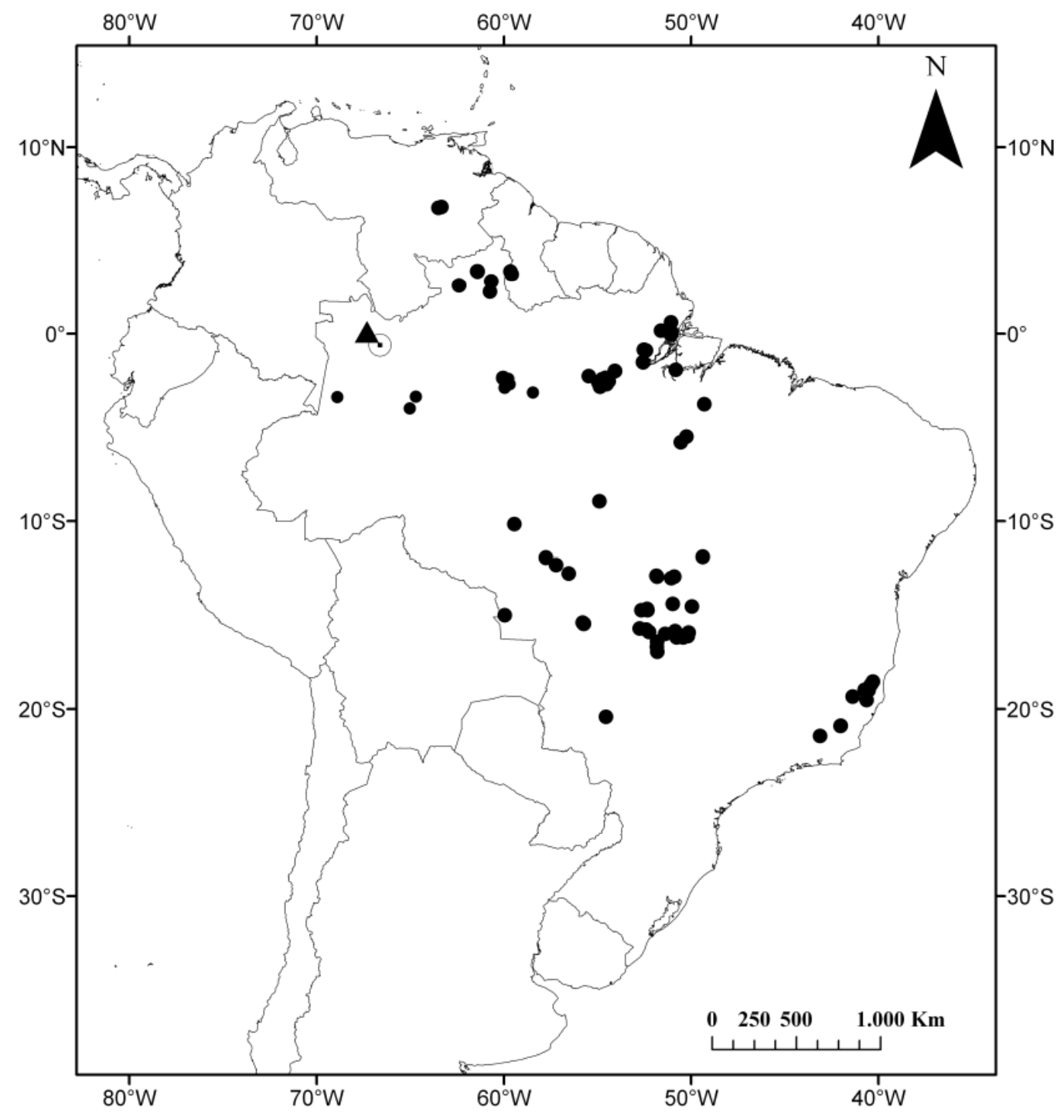

Figura 11: Mapa de distribuição geográfica de Mezilaurus caatingae (triângulo), $M$. crassiramea (pontos) e M. decurrens (círculo com ponto central). 
1.2. Mezilaurus crassiramea (Meisn.) Taub. ex Mez, Arbeiten Königl. Bot. Gart. Breslau 1: 112. 1892. Oreodaphne crassiramea Meisn. in DC., Prodr. 15 (1): 117. 1864. Misanteca crassiramea (Meisn.) Benth. in Hook. f., Icon. pl. 13 (3): 47. 1878. Silvia crassiramea (Meisn.) Mez, Jahrb. Königl. Bot. Gart. Berlin 5: 106. 1889. Mezia crassiramea (Meisn.) Kuntze, Revis. Gen. Pl. 2: 574. 1891. Tipo: Brasil. Goiás, Serra Dourada, s.d. Pohl 1463 (lectótipo designado aqui, $\mathrm{K}$; isolectótipos, $\mathrm{B}$ [destruído], $\mathrm{BR}, \mathrm{W}$ [destruído]).

(Figura 12).

= Mezilaurus lindaviana Schwacke \& Mez in Mez, Arbeiten Königl. Bot. Gart. Breslau 1: 112 . Tipo: Brasil. Amazonas, Rio Branco, Alto Amazonas, 1892, Schwacke 7080 (lectótipo escolhido por Kostermans (1938c), B [destruído]; lectótipo designado aqui, K; isolectótipo P). sin. nov.

= Misanteca duckei A. Samp., Comm. de Linhas Telegr. Estratégicas de Matto-Grosso ao Amazonas 56 (anexo 5, parte X): 15. 1917. Silvia duckei (A. Samp.) A. Samp., Bol. Mus. Nac. Rio de Janeiro 4: 40. 1928. Tipo: Brasil. Pará, Monte Alegre, 22/04/1916, Ducke s.n. (lectótipo escolhido aqui, R; isolectótipos, $\mathrm{B}$ [destruído], MG, MO, RB).

= Mezilaurus wurdackiana C. K. Allen, Mem. New York Bot. Garden 10:56. 1963. Tipo: Venezuela. Bolivar, $12 \mathrm{~km}$ east of Ranch House, headwaters of Rio Saca, Hato La Vergareña, 420-500m, 18/10/1954, Wurdack \& Guppy 91 (holótipo, NY; isótipos, US, VEN).

Árvores a arvoretas até $35 \mathrm{~m}$ alt. Ritidoma escamoso ou fissurado, marrom a cinza. Râmulos 3$12 \mathrm{~mm}$ diâm., cilíndricos, ferrugíneos, marrom a marrom-esverdeados, lanosos no ápice, tornando vilosos e pubescentes a medida que se afasta do ápice, com lenticelas conspícuas próximas do ápice; catafilos ovados a lanceolados, 2-5 $\mathrm{mm}$ compr., amarelos, creme a ferrugíneos, seríceos. Folhas alternas, 5-30 × 2-12,5 cm. Lâminas elípticas, largo-elípticas a obovadas, 1,2-3,2 vezes mais longas que largas, face abaxial hirsuta, vilosa ou lanosa, adaxial hirsuta, lanosa a subglabra ou raramente glabra, base aguda, cuneada, decorrente ou obtusa, simétrica, ápice agudo, acuminado, obtuso, arredondado ou raro emarginado, margem plana a 
ligeiramente revoluta, pontuações glandulares nas faces abaxial e adaxial presentes ou ausentes, muitas vezes inconspícuas. Venação broquidódroma a ligeiramente broquidódroma, 7-25 nervuras por lado, impressa a proeminente na face adaxial, proeminente na abaxial; nervuras secundárias formando um ângulo de $40-90^{\circ}$ com a primária, juntando com as suprajacentes em ângulos agudos a retos; terciárias reticuladas ou percorrentes, oblíquas. Pecíolo 1-18 $(-30) \times 2-5$ mm, representando 1-8 $(-10) \%$ da folha, plano, lanoso, base ligeiramente dilatada, Inflorescências do tipo duplo racemo (dibótrio) com ramos laterais não umbeliformes, axilares ou próximas do ápice dos ramos, 5-17 (-20) cm compr., menores, do mesmo tamanho ou maiores que as folhas, vilosas; ramos laterais $0,5-5,1 \mathrm{~cm}$ compr., 7-23 (-30) flores por ramo lateral; pedúnculos 1-6,7 cm compr. Bractéolas na base dos ramos laterais $1-1,2 \times 0,5-1 \mathrm{~mm}$, bractéola na base dos pedicelos $1,0,25-1 \times 0,25-0,8 \mathrm{~mm}$, triangulares a ovadas, pubérulas a lanosas ou pubérulas somente na margem do ápice, persistentes. Pedicelo 0,5-5 mm compr., pubescente, pubérulo a glabro, tricomas papilosos e/ou não papilosos. Flores 1,25-2,5 mm diâm., 1,25-3,5 mm compr., creme, amarelas a verdes, globosas a elipsoides, externamente pubescentes, pubérulas a glabras, tricomas papilosos. Tépalas iguais a desiguais, quando desiguais, externas menores, externas $0,25-0,75 \times 0,5-1 \mathrm{~mm}$, internas $0,5-1 \times 0,5-1,5 \mathrm{~mm}$, ovadas, ápice obtuso a arredondado, margem papilosa, internamente pubescentes, menores que o receptáculo, $1 /{ }_{3}-1 / 5$ do comprimento da flor. Estames livres, $0,75-1,8 \times 0,5-1,25 \mathrm{~mm}$, exsertos na antese; anteras $0,5-1$ $\times 0,5-1 \mathrm{~mm}$, extrorsas, triangulares, ovado-triangulares ou arredondadas, glabras frontalmente, pubescentes na face dorsal, papilosas; filetes $0,2-1 \times 0,4-1 \mathrm{~mm}$, quadráticos ou retangulares, do mesmo tamanho a maiores que as anteras, raro menores, pubescentes. Estaminódios ausentes ou raramente 1 por flor, pertencente à série IV do androceu, ca. $0,75 \times 0,5 \mathrm{~mm}$, estipitiformes, pubescentes. Pistilo 1-2,25 mm compr., glabro; ovário 0,5-1,5 mm compr., ovoide a elipsoide; estilete 0,4-1 mm compr., exserto na antese. Receptáculo 0,75-1 $\mathrm{mm}$ compr., pubescente internamente. Frutos até $31 \times 28 \mathrm{~mm}$, elipsoides a obovoides, glabros. Cúpulas 3-8 mm diâm., 
planas a pateliformes, externamente pubérulas a glabras, internamente pubescente a pubérulas, diâmetros maiores que os pedicelos na frutificação. Pedicelo na frutificação 2-6 mm compr., liso, pubérulo a glabro, bractéolas decíduas ou persistentes.

Material examinado: BRASIL. Amapá: Camaipi, EMBRAPA reserve and vacinity (0¹0`N/51³7’W), 20/07/1983, veg., S. Mori et al. 16482 (HAMAB); Macapá, APA de Curiaú, 01/10/1993, fr., J. A. Ratter \& T. M. Sanaiotti 6911 (INPA, K); arredores da cidade de Macapá, 14/07/1951, fl., R. L. Froés \& G. A. Black 27453 (IAN, K [2 exsicatas], NY, R, RB); quadrícula SA-22-VB, Ponto 396, 04/05/1982, fl., N. A. Rosa \& M. R. Santos 4291 (HRB, INPA, MG, NY); margem da floresta de galeria e Cerrado da Estação de Pesquisa da EMBRAPA, 04/08/1993, veg., S. Bridgewater et al. 103 (HAMAB, K); Parque Florestal de Fazendinha, árvore 1712, 21/08/1984, B. V. Rabelo et al. 2777 (HAMAB, NY); Estrada Macapá-Santana, Mata em torno do IEPA (51 ${ }^{\circ} 37^{\prime \prime}$ W/00,2'’39'’S), 22/11/2010, fr., F. M. Alves 529 (ESA, SPF, CGMS); Santana, ilha de Santana $\left(0^{\circ} 04^{\prime} 13^{\prime} \mathrm{N} / 51^{\circ} 11^{\prime} 11^{\prime \prime}\right.$ W), 24/12/2005, veg. J. L. Freitas 79 (HAMAB); estrada Fazendinha-Santana-Macapá, 21/08/1984, B. V. Rabelo et al. 2772 (HAMAB, NY). Amazonas: Manaus, Estrada Manaus-Caracaraí, km 57, 21/09/1976, fl., J. $R$. Nascimento 14 (INPA). Espírito Santo: Águia Branca, Parque Nacional Municipal Recanto do Jacaré, 16/05/2004, fr., H. Q. Boudet-Fernandes \& A. M. Assis 3368 (ESA, MBML [2 exsicatas]); 23/04/2004, fr., A. M. Assis \& K. F. O. Faria 1024 (ESA, MBML); Boa Esperança, 18/05/1994, fr., H. Lorenzi s.n. (SPSF); Colatina, Estação Baunilha, Córrego Santini, 1951, veg., J. A. Kuhlmann s.n. (RB); Nova Esperança, 25/09/1991, fr., H. Lorenzi s.n. (SPSF); Nova Venécia, Estrada para São Gabriel da Palha, $7 \mathrm{~km}$ de Nova Venécia, próximo as montanhas de pedra, 18/05/1994, fl., H. Lorenzi 1526 (HPL); São Gabriel da Palha, margem da rodovia entre São Gabriel da Palha e Nova Venécia, 18/05/1994, fl., fr., G. F. Arbocz 386 (MBM, SPSF). 
Goiás: Aragarças, Cerrado próximo de Aragarças, 9/04/1958, fl., A. Lima 58-3027 (IPA, K, PEUFR, RB); Buriti de Goiás, entre os municípios Buriti de Goiás e Goiás, cabeceira do rio Índio Grande, 15/04/1994, fl., J. A. Rizzo et al. 11293 (ESA, UFG [2exsicatas]); Caiapônia, Faz. Maracaná (16 57' S 51 49' W), 12/11/1993, fl., fr., J. A. Ratter et al. 7115 (K, UB, UFG); 9 km de Caiapônia em direção a Piranhas, BR 158, 07-09/1983, W. A. Rodrigues 10336 (UEC); Crixás, 25/03/1978, f1., J. G. Guimarães 97 (RB); Goiás, cerca de 15 km S de Goiás Velho, 10/05/1973, fl., fr., W. R. Anderson 10003 (MBM, NY, RB, U, UB); divisão do município de Goiás e Buriti de Goiás, 18/03/1994, fl., J. A. Rizzo et al. 11162 (ESA, UFG); divisão do município de Goiás e Buriti de Goiás, 13/05/1994, fl., J. A. Rizzo et al. 11361 (ESA, UFG); Gurupi, 25 km S de Gurupi na Belém-Brasília, 9/09/1997, veg., J. A. Ratter et al. 7957V (E, K, UB); Jussara, Faz. Santa Rita do Araguaia, 120 km de Jussara, 23/03/2006, fl., A. Pott 14138 (HMS); 26 km de Jussara para a Fazenda Nova, 27/11/1996, veg., J. A. Ratter et al. 7709V (E, K, UB); Montes Claros de Goiás, Aparecido do Rio Claro, 11/03/2004, fl., L. C. Bernacci et al. 3684 (IAC); Mossâmedes, Serra Dourada, divisão entre os municípios Mossâmedes ao Sul e Goiás ao norte, 4/05/1969, fl., J. A. Rizzo 4220 (ESA, UFG, RB); entre Mossâmedes e Goiás, norte da área da UFG, 5/04/1969, fl., J. A. Rizzo 4069 (ESA, RB, UFG); 3 km do trevo para Goiânia, a esquerda da rodovia, 18/02/1994, fl., J. A. Rizzo et al.11031 (ESA, UFG); 17/03/1994, fl., J. A. Rizzo et al. 11119 (ESA, UFG); Piranhas, próximo a Piranhas, 18/03/1981, fl., M. T. M. Silva 38 (HRB); Serra Dourada, 13/05/1994, fl., J. A. Rizzo 11361 (UFG); próximo aos córregos Cafundó e Piçarrão, 16/06/1994, fl., J. A. Rizzo et al. 11429 (ESA, UFG); próximo aos córregos Cafundó e Piçarrão, 14/04/1994, fl., J. A. Rizzo et al. 11254 (ESA, UFG). Mato Grosso: Aripuanã, arredores do campo de aviação, 19/06/1979, fl., fr., M. G. Silva \& Rosário 5018 (HAMAB, INPA, MAC, MG, NY); Barra do Garças, Serra Azul, cerca de $7 \mathrm{~km}$ a oeste de Barra do Garças, 19/06/1966, fl., fr., D. R. Hunt \& J. F. Ramos 6082 (K [2 exsicatas], UB); Chapada dos Guimarães, 7/05/1983, fl., fr., A. T. Oliveira-Filho 53 (UEC, UFMT, SPSF); 3/03/1983, fl., 
E. C. C. Moraes et al. 112 (UFMT); Faz. Invernada, 30/04/2002, fl., Z. S. Loneto \& Dimas 2399 (INPA); Véu da Noiva, 19/03/1983, fl., P. Lisboa et al. 3071 (MG); 18/03/1983, fl., A. T. Oliveira-Filho 08 (UEC, UFMT); Cocalinho, Fazenda Tracajá, 08/08/2000, fr., B. S. Marimon 582 (UB); Fazenda Volpec, 26/06/2000, fl., B. S. Marimon 507 (UB); 1997, fr., G. F. Árbocz et al. 4768 (ESA); General Carneiro, paredão grande, BR 070, 18/02/1997, G. F. Árbocz et al. 3244 (ESA); Juína, Entre Juína e Primavera, 05/1918, fl., J. G. Kuhlmann 1977 (R); entre Juína e Primavera, 05/1918, fl., J. G. Kuhlmann 1978 (RB); Nova Xavantina, 8/04/1996, fl., J. A. Ratter et al. 7454 (E, K, UB); 7 km sudoeste de Xavantina, 3/04/1968, fl., J. A. Ratter et al. 805 (K, NY, P, RB, U); Faz. Brasil (1453’S/52²2’W), 28/03/1997, fl., G. F. Árbocz et al. 3697 (ESA, SPF); 7 km SW de Xavantina, 2/09/1967, fr., J. A. Ratter \& J. Lemos 572 (K, NY, P); Ribeirão Cascalheira, $270 \mathrm{~km} \mathrm{~N}$ de Xavantina (12 $\left.54^{\prime} \mathrm{S} / 51^{\circ} 52^{\prime} \mathrm{W}\right), 6 / 05 / 1968$, fl., J. A. Ratter et al.1293 (IAN, K, MO, NY, P, RB, U, UB); 8 km NE da base do campo de expedição, base do campo de expedição (1254'S/5152'W), 9/04/1968, fl., J. A. Ratter et al. 912 (K, NY, P, UB); estrada para Piabanha, 31/05/1997, fl., R. Goldenberg 434 (ESA, UEC); Tapurah, estrada do Capixaba, 20 km NE de Tapurah (12³7'S/56 $22^{\circ}$ 'W), 12/06/1997, fl., V. C. Souza et al. 17854 (ESA, SPF); Vila Bela da Santíssima Trindade, BR 364, rodovia Cuiabá-Porto Velho, km 80, Distrito de Patronal, 10/06/1984, fl., C. A. Cid et al. 4453 (INPA, MG, MO, NY). Mato Grosso do Sul: Campo Grande, Parque dos Poderes, Academia de Polícia Civil, planta junto ao arame, cerca a $80 \mathrm{~m}$ a

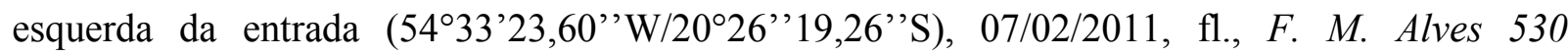
(CGMS, ESA, SPF) Minas Gerais: Rio Novo, 1890, veg., Araújo 12 (R); Santa Rita do Itueta, 17/04/2002, fl., A. A. Luz 56 (CVRD, ESA); estrada Quatituba à Santa Rita do Atueta, 05/05/2009, fr., A. A. Luz 504 (CVRD, ESA); Tombos, Fazenda das Antilhas, 9/05/1941, fr., J. E. Oliveira 356 (BHCB, MO); Fazenda Cachoeira, 25/07/1935, fr., M. Barreto 1742 (BHCB, R [2 exsicatas]); Fazenda da Cachoeira, 08/07/1935, fr., M. Barreto 1481 (R). Pará: Almeirim, Rio Jutahy, 14/09/1923, fl., fr., A. Ducke s.n (RB, U); Almeirim, área do água azul, 15/03/1980, fl., 
N. T. Silva 5243 (INPA, MG); estrada Santarém-Cuiabá, BR 165, km 75, 13/02/1976, veg., L. P. F. 662 (INPA); zona Jotoarana, Estrada Santarém-Cuiabá, BR 165, km 103, 28/11/1975, veg., L. P. F. 467 (INPA); estrada Santarém-Cuiabá, BR 165, km 76, 02/03/1976, veg., L.P. F. 640 (INPA); 17/07/1947, fl., fr., G. Black 47-1030 (IAC, IAN, INPA, UEC); Marabá, Serra Buritirama, rio Itacaiunas, afluente do rio Tocantins, 09/01/1970, veg., J. M. Pires \& R. P. Belem 13068 (IAN); Mararu, 27/06/1872, fl., J. B. Rodrigues 11 (RB); 27/06/1872, fl., J. B. Rodrigues 129 (R); Colônia Japonesa Assaizal, 24/09/1953, fr., R. L. Froés 30339 (IAN); região do Rio Jari, 16/09/1968, fr., N. T. Silva 996 (IAN, K, NY); Monte Dourado, Rio Jari, 03/07/1968, fl., E. Oliveira 4749 (IAN, NY); Rio Jari, ao longo da estrada que liga ao Munguba, 26/06/1968, fl., E. Oliveira 4673 (IAN); Rio Jari, ao lado do Aviário, 15/06/1968, fl., E. Oliveira 4538 (IAN); Munguba, estrada de Munguba, km 15, Região do Rio Jarí, 07/03/1969, fl., N. T. Silva 2306 (IAN, NY); Novo Progresso, Base aérea do Cachimbo, 19/07/1997, veg., W. Benson s.n. (INPA); Parauapebas, Serra dos Carajás, 07/06/1982, fl., fr., C. R. Sperling et al. 5948 (K, MG [2 exsicatas], NY); Portel, 25/10/1955, fr., L. Williams \& N. T. Silva 18231 (IAN, NY, RB); Rurópolis, Estrada Santarém-Cuiabá, BR 165, km 208, 30/01/1976, fl., L. P. F. 632 (INPA); Santarém, Camp. Anderson próximo a Tavio, região do Tapajoz, 27/04/1932, R. C. M. Costa 323 (IAN); segunda picada para o Igarapé da Lama, 19/06/1954, fl., R. L. Froés 30870 (IAN, SP); Ipanema, 05/09/1923, fr., A. Ducke s.n. (INPA [2 exsicatas], RB, U); margem direita do Rio Curuauna, Reserva Florestal do Curuauna, 26/08/1988, fl., fr., C. S. Rosário et al. 1024 (IAN, IBGE, MG); km 35 da estrada do Palhão, arredores do igarapé Curupira, 26/08/1969, fl., M. Silva \& R. Souza 2403 (MG, NY); planalto de Santarém, Igarapé de Laura, 07/1954, fl., R. L. Froés 30976 (ALCB, NY, P, R); Curuay (Lago Grande), 29/01/1938, veg., H. M. Bastos 341 (INPA, RB); Tucuruí, margem direita, BR 263, km 16, 14/6/1980, fl., M. G. Silva 5499 (HRB, MAC, MG); Pará, s.l. 08/1970, veg., J. M. Pires \& R. P. Belem 12867 (IAN); Pará, estrada PA 70, Fazenda Sta. Terezinha, km 15, 17/05/1976, veg. B. G. S. Ribeiro 1450 (IAN); Pará, s.l., s.d. 
veg., J. M. Pires 7368 (IAN). Roraima: Amajari, Ilha de Maracá, Reserva Ecológica SEMA, 19/09/1987, fl., W. Milliken \& R. Miller 571 (K, NY); SE tip of Island near the Ecological Station, Forest Inventory site, 07/10/1987, fl., J. Pruski et al. 3402 (NY, W); 1986, fl., D. Campbell 853 (MIRR); 1986, veg., D. Campbell 886 (MIRR); 1986, veg., D. Campbell 342 (MIRR); 1986, veg., D. Campbell 828 (MIRR); Boa Vista, Rio Branco, 10/1908, fl., E. Ule 7578 (G, K, L, MG, RB); 23/08/1943, fl., A. Ducke 1336 (IAN, NY, R); 07/1913, fl., J. G. Kuhlmann $588 a$ (K, RB); Rio Cauamé, Caçari, s. d., fl., s.c. s.n. (MIRR 6386); Cantá, Retiro da Serra da Lua, Rio Branco, 08/1913, fl., J. G. Kuhlmann s.n. (G, K, P, RB). Sem estado: Salinas, MaiJulho 1844, veg., M. A. Weddel 2066 (L); Estrada entre Tinguilim e Braço, km 22, 26/04/1969, fl., N. T. Silva 1911 (IAN, NY). Estrada entre Tinguilim e Braço, km 22, 08/06/1970, fl., N. T. Silva 3190 (IAN). Catalogus Geographicus Plantarum Brasilae Tropicae, s.d., fl., Burchell 6758 (K). GUIANA INGLESA. Alto Takutu-Alto Essequibo: Iramaipang, Kanucu Mts., 11/1948, fr., Fr. G. Wilson-Browne, S.J. 486 (WB 486) (K); Wabuwak, Kanucu Mts., 10/1948, fl., Fr. G. Wilson-Browne, S.J. 390 (WB 390) (K [2 exsicatas], U); Kanucu Mts. (Mountains), near source of Moco-moco CK., Takutu R. (River), 30/09/1931, fl., Forest Departament of British Guiana field No. D205/record No. 2196 (K, OXF); Western extremity of Kanucu Mountains, in drainage of Takutu River, 4-22/03/1938, fr., A. C. Smith 3208 (G, K, P, U, W). VENEZUELA. Bolivar: a lo largo de la pica maderera entre el Caño Maracapra y el Campamento La Esperanza. Reserva Florestal La Paragua, 02/1970, veg. C. Blanco 745 (VEN).

Distribuição e ecologia: Mezilaurus crassiramea é a espécie com distribuição geográfica mais ampla do gênero, ocorrendo desde o sudeste da Venezuela no estado de Bolivar, região administrativa de Alto Takutu-Alto Essequibo na Guiana e Brasil no norte, centro-oeste e sudeste (Figura 11). A espécie ocorre na sub-região Amazônica, províncias da Guiana, Guiana Úmida, Roraima, Madeira, Amapá, Várzea, Pará, Tapajós-Xingu e Pantanal; na sub-região Chaquenha, 
está representada na província do Cerrado; na sub-região Paranaense ocorre na província da Floresta Atlântica Brasileira e Floresta Paranaense (Figura 1). A distribuição geográfica da espécie alcança áreas próximas aos limites de ocorrência do gênero, com $6^{\circ} 45^{\prime} \mathrm{N}$ e $63^{\circ} 50^{\prime} \mathrm{W}$

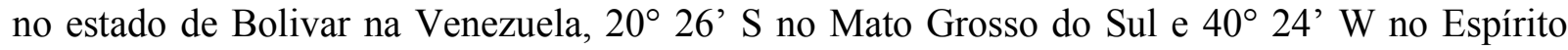
Santo, Brasil (Figura 11). Mezilaurus crassiramea ocorre desde a floresta estacional e floresta de terra firme, no Cerrado do Brasil central até a Floresta Atlântica do sudeste do Brasil no extremo leste de Minas Gerais e Espírito Santo. A espécie foi coletada em solos mais arenosos no Brasil central e argilosos na região amazônica, entre 15 e $1000 \mathrm{~m}$ de altitude. Os frutos de Mezilaurus crassiramea fazem parte da dieta de pássaros e, segundo Andrade (comunicação pessoal), macacos muriquis (Brachyteles hipoxanthus) também se alimentam dos frutos e sementes da espécie no sudeste do estado de Minas Gerais no Brasil e podem ser eventuais dispersores de suas sementes.

Fenologia: Coletada com flores de janeiro a novembro e com frutos de fevereiro a novembro.

Etimologia: o epíteto crassiramea é uma referência aos ramos crassos do espécime-tipo.

Status de conservação: Mezilaurus crassiramea possui distribuição geográfica bastante ampla, com grande quantidade de espécimes coletados, inclusive recentemente. Portanto, a espécie deve ser considerada como "Menor Preocupação" (LC) (IUCN 2001). No caso específico do estado brasileiro do Espírito Santo, Mezilaurus crassiramea está na lista de espécies ameaçadas de extinção como “Criticamente em Perigo" (Kollman et al. 2007).

Nome popular: cumbuca, cumbuquinha, itaúba-abacate (Brasil Central), tapinhoã (Espírito Santo), canella-marmellada, canela-cajú, canela-roxa, canella-tapinhoam (Minas Gerais), itaúba, itaúba-abacate, itaúba-amarela, itaúba-da-mata, mãe-de-itaúba (norte do Brasil), Rukut (Wapisiana), Tauwa-yet (Makasi) (Guiana), chupon, tripa de perro (Venezuela).

Importância econômica: A madeira de $M$. crassiramea é utilizada para construção civil (Corrêa \& Penna 1969). De acordo com Lorenzi (2002), a madeira é empregada para confecção de 
caibros, vigamentos, tábuas para assoalhos e marcos para portas, móveis e para uso externo como pontes, postes, cruzetas e obras hidráulicas. A árvore é recomendada para paisagismo por possuir atributos ornamentais.

Mezilaurus crassiramea é caracteriza-se por apresentar lâminas foliares na face abaxial hirsutas, vilosas a lanosas, inflorescências do tipo duplo racemo (dibótrio) com ramos laterais não umbeliformes, bractéolas persistentes e tépalas menores que o receptáculo, $1 / 3^{-}{ }^{1} / 4$ do comprimento da flor.

Além de Mezilaurus crassiramea, na região do Cerrado brasileiro ocorrem também $M$. itauba, M. vanderwerffii, M. synandra e M. microphylla. Tais espécies apresentam, ao contrário de $M$. crassiramea, lâminas foliares com face abaxial glabra a subglabra e inflorescência do tipo duplo racemo (dibótrio) com ramos laterais umbeliformes.

Espécimes de Mezilaurus crassiramea, apenas com material vegetativo, oriundas da Guiana, Venezuela e no estado de Roraima, possuem características morfológicas muito semelhantes a M. duckei. Todavia, a última espécie apresenta lâminas foliares pubérulas na face abaxial e nove estaminódios, representando as séries I e II e IV do androceu.

Silva \& Souza 2403 e da Costa 323 são colocados aqui com hesitação, pois compartilham lâminas foliares com indumento mais esparso. Por outro lado, os ramos, os pecíolos e as nervuras principais das lâminas foliares com indumento mais denso, incluem estas coleta em $M$. crassiramea.

Mezilaurus crassiramea e M. lindaviana foram consideradas distintas baseadas nas seguintes características: $M$. crassiramea é representada por arbustos ou pequenas árvores da região do Cerrado brasileiro com lâminas foliares revolutas e flores pubescentes, enquanto $M$. lindaviana, possui representantes arbóreos da floresta chuvosa, com lâminas foliares planas e flores glabras (van der Werff 1987). Com mais de 120 coleções analisadas no presente trabalho, 
pode-se concluir que, apesar dos materiais-tipo de M. crassiramea e M. lindaviana apresentarem extremos da variação da espécie, todos os intermediários com relação às características citadas anteriormente, puderam ser observados.

O espécime Cid et al. 4453 foi coletado em área de Cerrado no estado do Mato Grosso e corresponde a uma árvore com sete metros de altura, com camada suberosa nos ramos, lâminas foliares planas e flores glabras. A coleta de Ratter et al. 912, oriunda de um Cerrado no Mato Grosso, apresenta flores pubérulas e lâminas foliares revolutas ou planas. Por outro lado, Kuhlmann 588 a, coletado no estado de Roraima possui folhas revolutas e flores pubérulas. Silva 5243, um espécime coletado na floresta baixa de terra firme de Almeirim na Amazônia paraense, é uma árvore com 22 metros de altura, lâminas foliares revolutas e flores pubérulas. Em adição, o espécime Ratter \& Sanaiotti 6911, possui características muito próximas ao espécime-tipo de $M$. lindaviana, mas fora coletado em um Cerrado no estado do Amapá.

$\mathrm{Na}$ espécie, a ocorrência de lâminas foliares revolutas e flores pubérulas ou lâminas planas e flores glabras não está ligada a ocupação do Cerrado ou da Amazônia. Espécimes coletados no Cerrado ou na Amazônia podem apresentar características que foram utilizadas para separar os materiais-tipo de M. lindaviana e M. crassiramea como espécies distintas. Além do mais, tanto Mezilaurus crassiramea quanto M. lindaviana são citadas para áreas de Cerrado (Castro et al. 1999; Sanaiotti et al. 1997; Alves \& Miranda 2008; Quinet et al. 2010).

Misanteca duckei e Mezilaurus wurdackiana foram também colocados aqui como sinônimos de M. crassiramea. O material-tipo de Misanteca duckei (Ducke s.n.) apresenta folhas planas e flores glabras, enquanto espécimes-tipo de Mezilaurus wurdackiana (Wurdack \& Guppy 91) possui folhas planas a ligeiramente revolutas e flores pubérulas. No presente trabalho, os dois nomes são considerados como sinônimo de $M$. crassiramea porque os materiais-tipo apresentam características incluídas dentro da variação da espécie. 
Meissner (1864) descreveu Oreodaphne crassiramea citando síntipos depositados nos herbários BR, K, e W (Mart., Hook. e Vindob.), correspondentes à coleta de Pohl 1463. Kostermans (1938c), ao revisar Mezilaurus, elegeu um lectótipo proveniente do herbário G-DC (Genebra na Suiça). Kostermans (1938c) citou a coleta de Pohl 1463 do herbário G-DC apenas no cabeçalho da espécie, mencionando no material examinado somente as duplicatas oriundas dos herbários K e W. Porém, o possível lectótipo escolhido por Kostermans (1938c), não foi encontrado no herbáro G-DC (Genebra na Suiça).

Kostermans (1938c), ao escolher alguns lectótipos, citou-os tanto no cabeçalho da espécie quanto no material examinado. Todavia, ao escolheu lectótipos para os herbários G-DC e os brasileiros MG, R e RB, o autor citou-os apenas no cabeçalho da espécie, não referindo as coletas também no material examinado. Segundo L. B. T. Kostermans (comunicação pessoal), filho do autor, o motivo pelo qual o autor não citou no material examinado os espécimes-tipo depositados nos herbários brasileiros, foi porque ele nunca visitou tais coleções.

Segundo Fumeaux (comunicação pessoal) é possível que Kostermans (1938c) também tenha citado o espécime para o herbário G-DC apenas no cabeçalho da espécie, mesmo não tendo visto a coleção. Provavelmente o autor inferiu que o exemplar estivesse neste herbário, já que a espécie foi publicada por Meissner (1864) no Prodromus Systematis Naturalis Regni Vegetabilis, editorada por De Candole (G-DC). Além disso, Mez (1889) visitou o herbário G-DC para realizar a monografia "Lauraceae Americanae" e não citou esse exemplar.

Assim como está descrito no protólogo, foram encontrados somente dois espécimes de Pohl 1463, correspondendo aos dos herbários BR e K. A duplicata referente ao herbário do Museu de Histório Natural Viena (W) foi destruída durante a Segunda Guerra Mundial. Van der Werff (1987) citou também o espécime depositado no herbário U, porém, este exemplar não foi encontrado no local. Por essa razão, nós escolhemos, no presente trabalho, um lectótipo para 
Oreodaphne crassiramea, correspondendo ao exemplar do herbário do Royal Botanic Garden, Londres (K).

Sampaio (1917), ao descrever Misanteca duckei citou o espécime-tipo como "Habitat: prov. Pará: Monte Alegre, in sylvis ad marginen Campo Alegre: Dr. A. Ducke 16.032, Aprilis 1916”. Ao receber este material, Sampaio (1917) publicou a espécie colocando no protólogo uma fotografia da exsicata do herbário do Museu Nacional (R 2542). Por essa razão, nós escolhemos o exemplar do Herbário do Museu Nacional do Rio de Janeiro (R 2542) como lectótipo de Misanteca duckei.

Dos materiais originais de Mezilaurus lindaviana (Schwacke 7080), o lectótipo e um isólectótipo, escolhidos por Kostermans (1938c) e alojados nos herbários de B (Berlim) e W (Viena), respectivamente, foram destruídos durante a Segunda Guerra Mundial. Nesse período, cerca de quatro milhões de exsicatas foram destruídas no herbário B e Lauraceae foi uma das famílias mais atingidas (Vogt comunicação pessoal). O material do herbário $\mathrm{K}$ está em melhor estado de conservação e, por essa razão, nós aqui escolhemos um lectótipo para este herbário.

No prótologo de Mezilaurus lindaviana Schwacke \& Mez, Mez (1892) citou o síntipo Schwacke 7080, coletado em "Habitat in Brasiliae septentrionalis prov. Alto-Amazonas in campis ed Rio Branco". Posteriormente, Kostermans (1938c) mencionou "Schwacke 7080 = Glaziou 19798", coletado em "Minas Gerais, Serra d'Antonio Pereira" e lectotipificou este espécime depositado no herbário de Berlim (B). Schwacke disponibilizou algumas de suas coleções para Glaziou que por sua vez etiquetou como se tivessem sido coletadas por ele mesmo (Stafleu \& Cowan 1985), alterando as localidades de inúmeras coletas da Amazônia para Minas Gerais (Wurdack 1970). Carl Mez percebeu essa troca e em 1892 corrigiu essas informações na exsicata do herbário de Berlim (B), rasurando as anotações colocadas por Glaziou, mudando para as de Schwacke. Apesar do espécime do herbário de Berlim ter sido destruído durante a Segunda Guerra Mundial, uma fotografia do lectótipo foi preservada no Field Museum (F) e manteve tais 
informações. No entanto, as exsicatas depositadas nos herbários de Paris (P) e Londres (K) permaneceram ainda com as informações de Glaziou. Por essa razão, assim como van der Werff (1987), nós desconsideramos a citação da coleta Glaziou 19798 para Minas Gerais, sendo esta, considerada como de "Schwacke 7080, Brasil, Amazonas, in campis ed Rio Branco". 


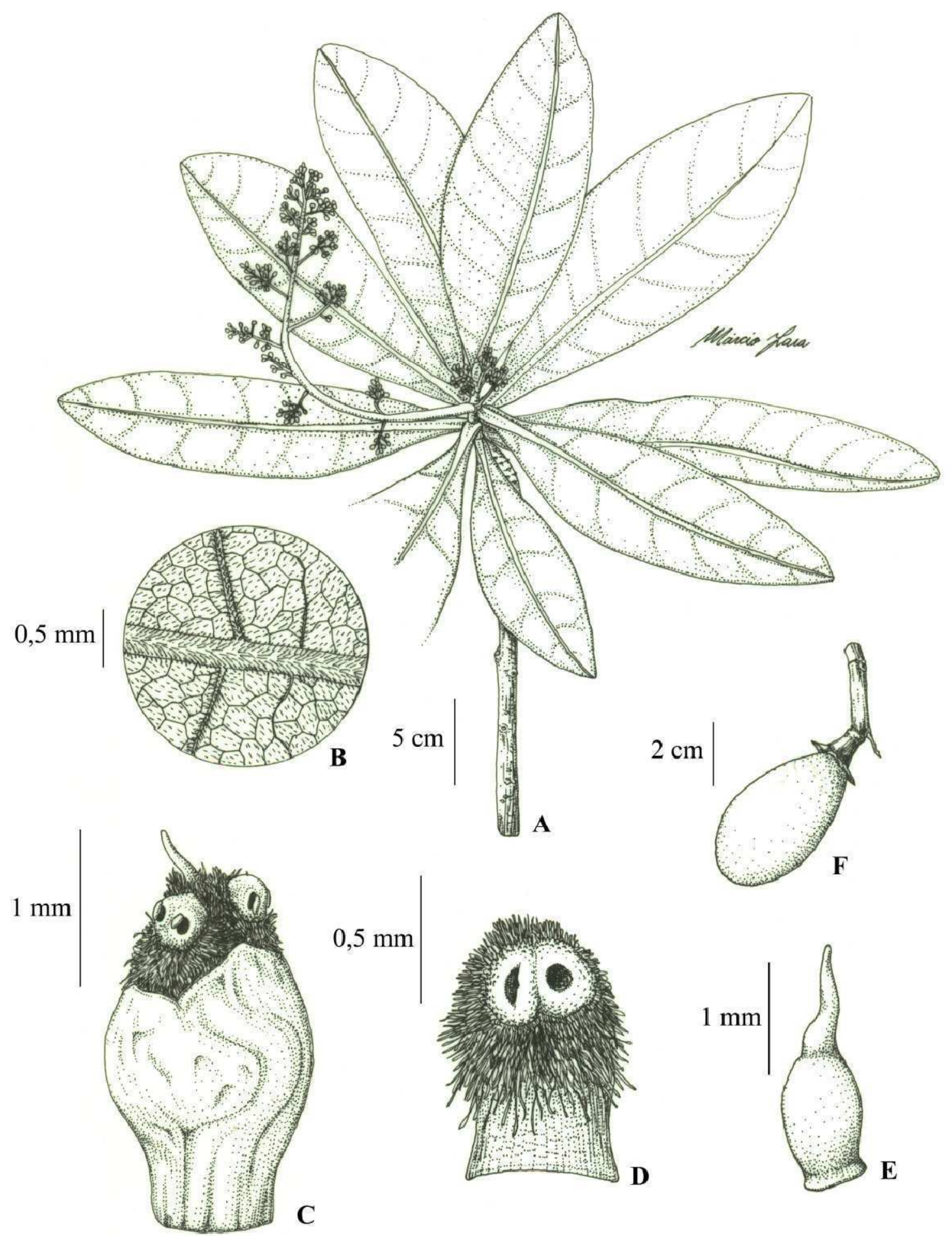

Figura 12: Ilustração de Mezilaurus crassiramea. A: ramo com flores; B: detalhe do indumento na face abaxial da lâmina foliar (Alves 530); C: flor; D: estame; E: pistilo; F: fruto (Rizzo et al. 11293). 
1.3. Mezilaurus decurrens (Ducke) Kosterm., Meded. Bot. Mus. Herb. Rijks Univ. Utrecht 25 (13): 40. 1936. Silvia decurrens Ducke, Trop. Woods 42: 19. 1935. Tipo: Brasil. Amazonas, Alto Rio Negro, acima do afluente Curicuriary, 19/11/1929, Ducke 55 (lectótipo, escolhido por Kostermans (1938c), RB; isolectótipos, B [destruído], F, K, US, W [destruído]). （Figura 13).

Árvore. Ritidoma desconhecido. Râmulos 3-6 mm diâm., cilíndricos, ferrugíneos a marrom, pubescentes a pubérulos no ápice, com lenticelas conspícuas próximas do ápice; catafilos ovados a lanceolados, 2-3 mm compr., creme, seríceos. Folhas alternas, 13-27 × 3,7-7,2 cm. Lâminas estreito-elípticas ou oblanceoladas, 3,2-3,8 vezes mais longas que largas, glabras, base decorrente a cuneada, simétrica, ápice agudo a obtuso, margem plana, pontuações glandulares na face abaxial, muitas vezes inconspícuas. Venação ligeiramente broquidódroma, 10-16 nervuras por lado, ligeiramente proeminente na face adaxial, proeminente a imersa na abaxial; nervuras secundárias formando um ângulo de $60-85^{\circ}$ com a primária, juntando com as suprajacentes em ângulos agudos ou retos; terciárias reticuladas ou percorrentes, oblíquas. Pecíolo 10-22 × 3-5 $\mathrm{mm}$, representando 5-8\% da folha, plano, pubérulo, base dilatada. Inflorescências do tipo duplo racemo (dibótrio) com ramos laterais umbeliformes, próximas do ápice dos ramos, 10-18 cm compr. (Kostermans 1938), pubérulas; ramos laterais ca. $2 \mathrm{~cm}$; pedúnculos ca. 4,5 cm compr. Bractéolas na base dos ramos laterais não vistas, bractéola na base dos pedicelos 1 , ca. $0,5 \times 0,5$ mm larg, pubérulas, decíduas. Pedicelo ca. $3 \mathrm{~mm}$ compr., pubérulo, tricomas não papilosos. Flores ca. $2 \mathrm{~mm}$ diâm., ca. 2,5 mm compr., cor desconhecida, elipsoides, externamente pubérulas, tricomas não papilosos. Tépalas iguais a subiguais, quando subiguais, externas ligeiramente menores, ca. $0,75 \times 1 \mathrm{~mm}$, ovadas, ápice obtuso, margem papilosa, internamente pubescentes na base, menores que o receptáculo, $1 / 3-1 / 4$ do comprimento da flor. Estames conados, ca. 1,2 $\times 0,5 \mathrm{~mm}$, exsertos na antese; anteras ca. $0,4 \times 0,5 \mathrm{~mm}$, extrorsas, arredondadotriangulares, glabras frontalmente, pubescentes na face dorsal, papilosas no ápice; filetes ca. $0,8 \times$ 
0,4 mm, retangulares, maiores que as anteras, pubescentes. Estaminódios ausentes. Pistilo ca. 2 mm compr., pubescente no ovário; ovário ca. 1,25 mm compr., globoso; estilete $0,75 \mathrm{~mm}$ compr., exsertos na antese. Receptáculo, 0,75-1 mm compr., pubescentes internamente. Fruto desconhecido.

Distribuição e ecologia: Mezilaurus decurrens apresenta distribuição restrita ao Brasil, conhecida somente pelo espécime-tipo, coletado no extremo noroeste do estado do Amazonas (Figura 11). A espécie ocorre na sub-região Amazônica, província de Imerí (Figura 1); coletada em uma região próxima de $100 \mathrm{~m}$ de altitude.

Fenologia: coletada com flores em novembro.

Etimologia: o epíteto decurrens é uma referência à base de suas folhas decorrentes.

Status de Conservação: Mezilaurus decurrens possui distribuição restrita, conhecida por uma coleta no noroeste do Brasil, estado do Amazonas. Portanto, não há informação precisa sobre seu risco de extinção, baseado na distribuição geográfica ou status da população. Por essa razão, a espécie deve ser considerada, segundo IUCN (IUCN 2001), como "Dados Deficientes" (DD). A espécie foi considerada rara (Baitello et al. 2009) e seu local de ocorrência é uma área-chave para a conservação da biodiversidade brasileira (Kasecker et al. 2009).

Nome popular: desconhecido.

Importância econômica:: desconhecida.

Mezilaurus decurrens é caracterizada por seus râmulos pubérulos no ápice, lâminas foliares estreito-elípticas ou oblanceoladas, glabras, pecíolo pubérulo, inflorescência do tipo duplo racemo (dibótrio) com ramos laterais umbeliformes, pubérulas, uma bractéola na base dos pedicelos, flores pubérulas, tépalas menores que o receptáculo, cerca de $1 / 3$ do comprimento da flor, estames conados e ovário pubescente. 
Vegetativamente, a espécie é muito semelhante à Mezilaurus caatingae, porém, esta última apresenta râmulos glabros, pecíolo glabro, três bractéola na base dos pedicelos e ovário glabro. A espécie pode ser confundida também com Mezilaurus itauba, todavia, esta possui lâmina foliar elíptica a obovada, estames livres, pistilo glabro.

Ao descrever Silvia decurrens, Ducke (1935) citou o síntipo, Ducke 55, depositado no RB (23669) e Yale (20999). Kostermans (1938c) elegeu o exemplar RB 23669 como lectótipo de Silvia decurrens. Um dos síntipos, citado por Ducke (1935) (Yale 20999), está hoje depositado no herbário do Field Museum (F), nos Estados Unidos. 


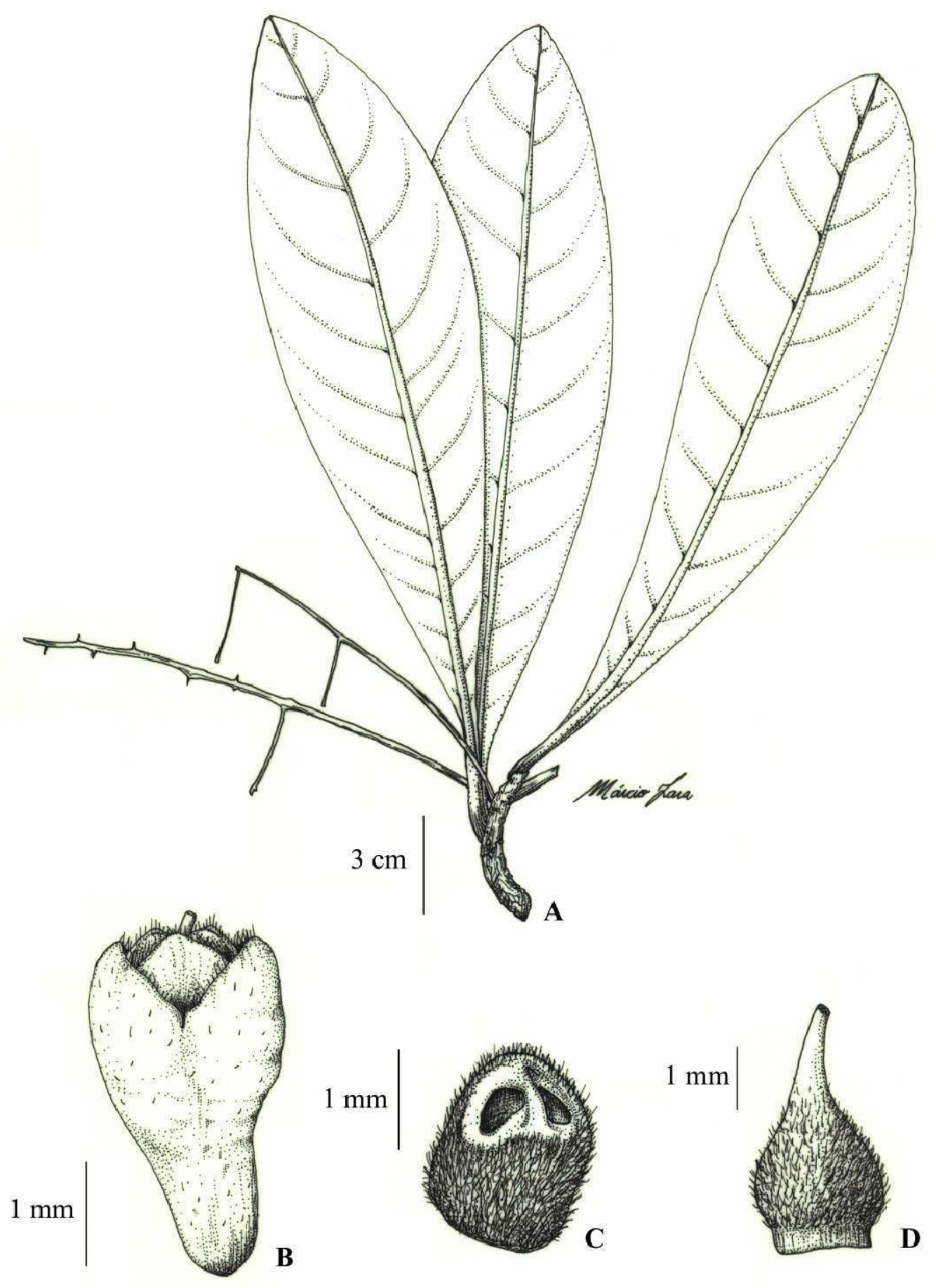

Figura 13: Ilustração de Mezilaurus decurrens. A: ramo com inflorescência; B: flor; C: estame; D: pistilo (lectótipo). 
1.4. Mezilaurus duckei van der Werff, Ann. Missouri Bot. Gard. 74: 162. 1987. Tipo: Brasil. Amazonas, Manaus, Reserva Florestal Ducke, 21/08/1968, Aluísio 98 (holótipo, US; isótipos, INPA, MG).

(Figura 14).

$=$ Mezilaurus pyriflora van der Werff, Ann. Missouri Bot. Gard. 74: 174. 1987. Tipo: Brasil. Amazonas, São Paulo de Olivença, basin of creek Belém, Oct. 26 - Dec. 11, 1936, Krukoff 8711 (holótipo, NY; isótipos, BM, GH, U). sin. nov.

Árvores até $30 \mathrm{~m}$ alt. Ritidoma escamoso, marrom-avermelhado. Râmulos 6-10 mm diâm., cilíndricos, ferrugíneos a marrom, pubescentes no ápice, com lenticelas conspícuas próximas do ápice; catafilos ovados a lanceolados, 4-9 mm compr., marrom a ferrugíneos, pubescentes. Folhas alternas, 13-59 × 4,5-17,5 cm. Lâminas elípticas, obovadas ou oblanceoladas, 2-4 vezes mais longas que largas, face abaxial pubérula, face adaxial glabrescente, base aguda a atenuada, simétrica, ápice agudo, ligeiramente acuminado a obtuso, margem plana, pontuações glandulares na face abaxial, muitas vezes inconspícuas. Venação broquidódroma a ligeiramente broquidódroma, 11-28 nervuras por lado, impressa na face adaxial, proeminente na abaxial; nervuras secundárias formando um ângulo de $50-90^{\circ}$ com a primária, juntando com as suprajacentes em ângulos agudos ou retos; terciárias reticuladas ou percorrentes, oblíquas ou perpendiculares no ápice das folhas. Pecíolo 3,5-13 × 3-6 mm, representando 1-5\% da folha, plano, pubérulo a pubescente, base dilatada. Inflorescências do tipo duplo racemo (dibótrio) com ramos laterais não umbeliformes, axilares ou logo abaixo das folhas congestas, $14-45 \mathrm{~cm}$ compr., do mesmo tamanho a menores que as folhas, pubérulas; ramos laterais $0,8-5,5 \mathrm{~cm}$ compr., $14-26$ flores por ramo lateral; pedúnculos 4-14 cm compr. Bractéolas na base dos ramos laterais 1-2 $\times$ 0,75-1 mm, uma bractéola na base dos pedicelos, elípticas, obovadas a lanceoladas, $0,25-1 \times$ 0,2-0,5 mm, triangulares a ovadas, pubescentes a pubérulas, persistentes. Pedicelo $1-3 \mathrm{~mm}$ compr., glabro ou pubescente a pubérulo, tricomas não papilosos. Flores 1-1,25 mm diâm., 1- 
1,25 mm compr., amarelas a verdes, globosas, externamente glabras ou raro pubérulas na base, tricomas não papilosos. Tépalas iguais ou ligeiramente desiguais, quando desiguais, externas menores, externas $0,25-0,5 \times 0,4-0,5 \mathrm{~mm}$, internas $0,3-0,5 \times 0,5-0,6 \mathrm{~mm}$, ovadas, ápice agudo a arredondado, margem papilosa, internamente pubescentes na base, menores que o receptáculo, $1 / 3^{-1 / 5}$ do comprimento da flor. Estames livres, $0,5-0,75 \times 0,4-0,75 \mathrm{~mm}$, inclusos na antese; anteras $0,2-0,4 \times 0,4-0,5 \mathrm{~mm}$, apical-extrorsas, triangulares, glabras frontalmente, pubescentes na face dorsal, ligeiramente ou não papilosas no ápice; filetes $0,25-0,5 \times 0,4-0,7 \mathrm{~mm}$, quadráticos ou retangulares, do mesmo tamanho a maiores que as anteras, pubescentes. Estaminódios 9, representando as séries I, II e IV do androceu, ca. 0,4 × 0,2-0,3 mm, quadráticos, pubescentes. Pistilo 0,8-1,3 mm compr., glabro; ovário 0,4-0,9 mm compr., globoso a elipsoide; estilete $0,4-0,5 \mathrm{~mm}$ compr., incluso na antese. Receptáculo 0,5-0,75 mm compr., pubescente internamente. Frutos até $17 \times 13 \mathrm{~mm}$, elipsoides, glabros. Cúpulas 2,5-4,5 mm diâm., pateliformes, externamente glabras, internamente pubérulas, diâmetros maiores que os pedicelos na frutificação. Pedicelo na frutificação 1,25-2,5 mm compr., liso, glabro a subglabro, bractéolas persistentes.

Material examinado: BRASIL. Amazonas: Manaus, Manaus-Itacoatiara, Reserva Florestal Ducke, 15/07/1997, fr., P. A. C. L. Assunção et al. 541 (INPA, K, MG, NY, SP); 05/08/1994, fl., A. Vicentini et al. 654 (INPA, K, MG, MO, NY, RB, SP, U); 08/09/1980, fl., H. Kurz B31 (INPA); 26/05/1966, veg., W. Rodrigues \& D. Coelho 7873 (INPA); 10/07/1988, fl., L. Wilde 26 (INPA); 05/08/1980, fl., H. Kurz B24 (INPA, MO); 05/07/1976, veg., Lourival s.n. (INPA); 11/1972, veg., W. Rodrigues 9150 (INPA); 26/06/1997, fr., A. Vicentini et al. 1218 (INPA); 12/06/1979, fl., H. Kurz B1 (INPA); 22/02/1968, veg., L. Coelho \& D. Coelho s.n. (INPA); 18/09/1973, veg., D. Coelho s.n. (INPA); 29/06/1976, veg., L. Q. Reis s.n. (INPA); 09/04/2008, veg., F. M. Alves 524 (ESA); Estrada Manaus-Itacoatiara, km 138, 26/05/1965, fl., W. Rodrigues 
\& D. Coelho 6943 (INPA); Estrada Manaus-Itacoatiara, km 73, 25/08/1965, fr., W. Rodrigues \& A. Loureiro 7039 (INPA); Manaus-Itacoatiara km 26, 08/07/1995, fl., A. Vicentini \& E. C. Pereira 992 (INPA, K, MG, SP, U); Manaus-Itacoatiara km 26, 27/02/1976, veg., F. Mello s.n. (INPA); próximo da estação meteorológica, 15/06/2005, fl., fr., J. E. C. Souza 1272 (INPA); Reserva 1501 (km 41) do PDBFF, 90 km NNE de Manaus, 03/01/1993, veg., A. Adelardo de Oliveira et al. 1349 (SPF); Reserva Florestal Ducke, árvore 116, 29/07/1966, fl., W. Rodrigues \& Osmarino 8203 (COL, NY); Distrito Agropecuário da SUFRAMA, BR 174, km 72, 6 km Oeste da BR, Fazenda Dimona, 07/10/1982, veg., C. A. Mackenzie et al. s.n., INPA/WWF 2206.2089 (MO); Rio Tefé, 27/04/1976, fr., Magnago et al. s.n. (INPA, MG); Tefé, Lago Tefé, 15/01/1991, fl., C. A. Cid et al. 10376 (INPA).

Distribuição e ecologia: Mezilaurus duckei é restrita ao Brasil, conhecida somente para o estado do Amazonas. A espécie foi bem coletada na região da Amazônia central, em Manaus e seus arredores (Reserva Ducke), conhecida também para o oeste do estado, em São Paulo de Olivença e na região do Rio Tefé (Figura 15). Mezilaurus duckei ocorre na sub-região Amazônica, províncias de Várzea e Madeira (Figura 1). A espécie é característica da região Amazônica, ocorrendo floresta de terra firme, floresta de platô, vertente, em solo argiloso, de 50 a $125 \mathrm{~m}$ de altitude.

Fenologia: Coletada com flores em janeiro e de maio a outubro, frutos em abril e de junho a agosto.

Etimologia: o epíteto duckei é uma homenagem a Adolpho Ducke, botânico brasileiro e explorador da Amazônia (Archer 1962).

Status de conservação: Mezilaurus duckei apresenta distribuição geográfica restrita ao estado do Amazonas no Brasil, é pouco coletada e conhecidas para pontos fragmentados. Portanto, não há informação segura sobre o risco de extinção da espécie baseado na distribuição geográfica ou 
status da população. Por essa razão, M. duckei deve ser avaliada como "Dados Deficientes" (DD) (IUCN 2001). A espécie foi considerada rara (Baitello et al. 2009) e locais de sua ocorrência, tais como a Reserva Ducke e São Paulo de Olivença foram analisados como áreas-chave para a conservação da biodiversidade brasileira (Kasecker et al. 2009).

Nome popular: itaúba, itaúba-abacate, louro-itaúba-abacate, ubá.

Importância econômica: Não há registro de uso econômico para a espécie, mas possivelmente sua madeira é também esplorada para fabricação de embarcações na Amazônia, já que também é conhecida por "itauba" e ocorre na mesma área da espécie mais conhecida e amplamente distribuída do gênero, M. itauba.

Mezilaurus duckei é caracterizada pelas longas folhas, 13-59 cm compr., lâminas foliares obovadas, elípticas a oblanceoladas, pubérulas na face abaxial, inflorescências do tipo duplo racemo (dibótrio) com ramos laterais não umbeliformes, uma bractéola na base dos pedicelos, flores globosas, tépalas menores que o receptáculo, $1 / 3^{-1} / 5$ do comprimento da flor, estames inclusos na antese, nove estaminódios, representando as séries I e II e IV do androceu, pedicelo na frutificação $1,25-2,5 \mathrm{~mm}$, cúpulas $2,5-4 \mathrm{~mm}$ diâm., diâmetros maiores que os pedicelos na frutificação e bractéolas persistentes no fruto.

A espécie é muito semelhante a $M$. thoroflora, principalmente por compartilharem folhas em média grandes para o gênero, lâminas foliares oblanceoladas, pubérulas na face abaxial, inflorescências do tipo duplo racemo (dibótrio) com ramos laterais não umbeliformes, nove estaminódios, representando as séries I, II e IV do androceu e bractéolas persistentes até a fase de frutificação. Mezilaurus thoroflora apresenta porém, flores elipsoides, estames exsertos na antese, pedicelo na frutificação 9-13 mm compr., cúpulas 5-6,5 mm diâm., diâmetros menores que os pedicelos na frutificação. 
Espécimes de $M$. duckei são similares e podem ser confundidos com exemplares de $M$. crassiramea encontrados no norte da América do Sul. No entanto, M. crassiramea apresenta lâminas foliares na face abaxial hirsutas, vilosas a lanosa, flores elipsoides.

Van der Werff(1987), descreveu M. duckei baseado em Aluisio 98 (US) e Rodrigues 8203 (NY), enquanto M. pyriflora foi descrita, pelo mesmo autor, com Krukoff 8711 (GH, MO, NY). O autor relatou que $M$. duckei possuía folhas elípticas ou ligeiramente obovadas, ápice arredondado e pedicelos glabros, enquanto M. pyriflora apresentava folhas fortemente obovadas, ápice agudo a acuminado e pedicelos pubescentes. Todavia, os isótipos pertencentes a coleta Aluísio 98, depositados nos herbários INPA e MG, apresentam lâminas foliares elípticas, obovadas ou oblanceoladas, ápice agudo a ligeiramente acuminado ou obtuso (nunca arredondado) e pedicelos pubescentes, pubérulos ou glabros. Outras coletas, assim como, Vicentini et al. 654 e Vicentini \& Pereira 992, também apresentam folhas de elípticas a obovadas e pedicelos de glabros a pubescentes. Por esse motivo, Krukoff 8711 está dentro da variação de Aluísio 98, que apresenta folhas de elípticas a obovadas e pedicelos pubescentes, pubérulos a glabros. Por essa razão, nós sinonimizamos M. pyriflora em M. duckei, levando em consideração que não existem descontinuidades de características para separá-las como dois táxons.

Mezilaurus duckei e M. pyriflora são nomes legítimos de igual prioridade, já que foram publicados na mesmo protólogo (van der Werff 1987). Aqui adotamos Mezilaurus duckei, um nome mais usado e conhecido no meio botânico, com vasta coleção de espécies identificados como tal; o nome M. pyriflora é conhecido somente pelo espécime-tipo. Além do mais, os dois nomes foram publicados baseados em coletas oriundas do Brasil, não havendo prejuízo, portanto, da escolha do nome para nenhum outro país.

Segundo o princípio II do Código Internacional de Botânica: “A nomenclatura de um grupo taxonômico está baseada na prioridade de publicação". No artigo 11.5 "Quando para qualquer táxon do nível de família ou inferior for possível a escolha entre nomes legítimos de 
igual prioridade no nível correspondente, ou entre nomes de epítetos-finais disponíveis de igual prioridade no nível correspondente, a primeira escolha a ser efetivamente publicada (Art. 29-31) estabelece a prioridade do nome escolhido e de qualquer combinação legítima que possua o mesmo tipo e o epíteto final naquele nível sobre o (s) demais nomes competidores (mas veja Art. 11.6)" (McNeill et al. 2007). 


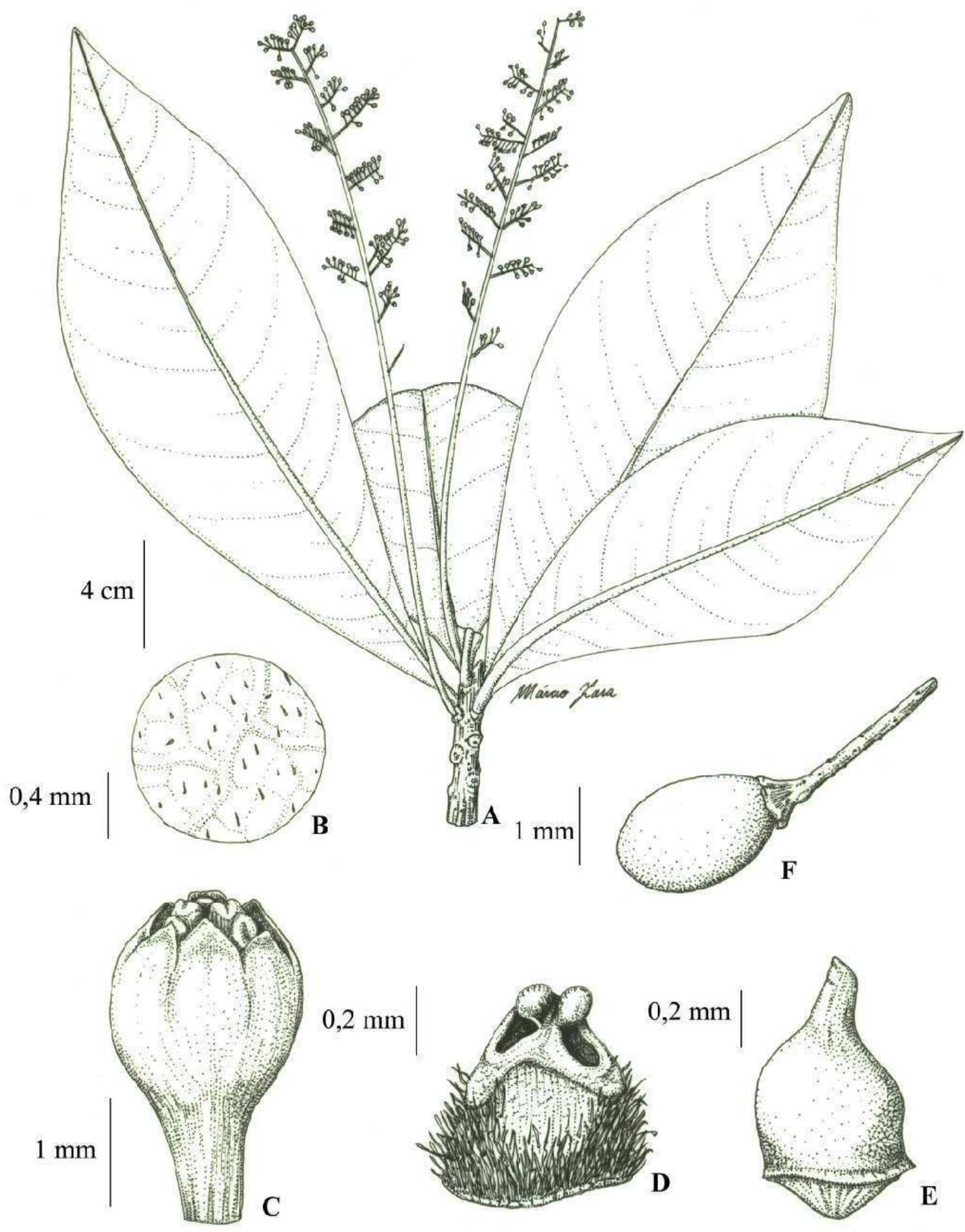

Figura 14: Ilustração de Mezilaurus duckei. A: ramo com flores; B: detalhe do indumento na face abaxial da lâmina foliar; C: flor; D: estame; E: pistilo (Vicentini \& Pereira 992); F: fruto (Assunção et al. 541). 


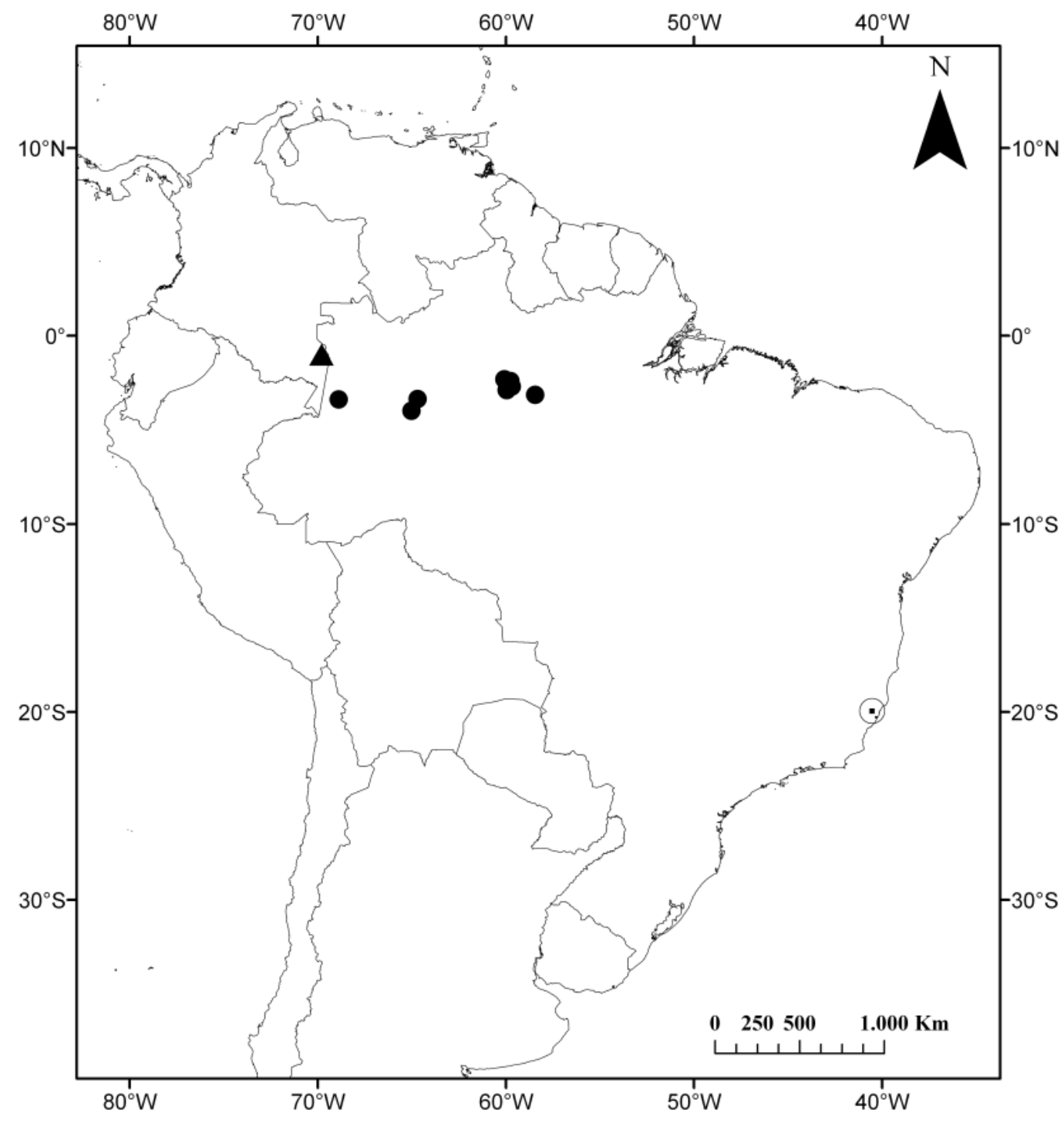

Figura 15: Mapa de distribuição geográfica de Mezilaurus duckei (pontos), $M$. glabriantha (círculo com ponto central) e M. introrsa (triângulo). 
1.5. Mezilaurus glabriantha F.M. Alves \& V. C. Souza, sp. nov. ${ }^{1}$ Tipo: Brasil. Espírito Santo, Santa Teresa, Estação Ecológica de Santa Lúcia, 8/12/1992, fl., L. D. Thomaz 1530 (holótipo, MBML; isótipos, ESA, SPSF).

(Figura 16).

A Mezilauro itauba petiolis non dilatatis, inflorescentiae ramis lateralibus glabris, floribus, staminibus atque hypanthio glabris differt.

Árvores até $14 \mathrm{~m}$ alt. Ritidoma rugoso, cinza a verde. Râmulos 3,5-7 mm diâm., cilíndricos, marrom, marrom-esverdeados, pretos e raramente glaucos, pubescentes a pubérulos no ápice, com lenticelas conspícuas próximas do ápice; catafilos ovados a lanceolados, 2-5 mm compr., amarelos, seríceos. Folhas alternas, 5,4-19,1 × 2,1-8,6 cm. Lâminas elípticas a obovadas, 1,72,8 vezes mais longas que largas, glabras a subglabras, base aguda, simétrica ou ligeiramente assimétrica, ápice agudo, obtuso ou raro ligeiramente cuspidado, margem plana, pontuações glandulares em ambas as faces presentes ou ausentes, muitas vezes inconspícuas. Venação broquidódroma a ligeiramente broquidódroma, 10-18 nervuras por lado, impressa na face adaxial, proeminente na abaxial; nervuras secundárias formando um ângulo de $60-90^{\circ}$ com a primária, juntando com as suprajacentes em ângulos agudos ou retos; terciárias reticuladas ou percorrentes, oblíquas. Peciolo 6-24 × 1,5-3 mm, representando 9-16\% da folha, plano a ligeiramente canaliculado, pubérulo, base não dilatada. Inflorescências do tipo duplo racemo (dibótrio) com ramos laterais umbeliformes, axilares, 4,1-5,1 cm compr., menores que as folhas, raque principal pubérula, ramos laterais glabros; ramos laterais $0,5-2,1 \mathrm{~cm}$ compr., 4-10 flores por ramo lateral; pedúnculos 1,5-2,2 cm compr. Bractéolas na base dos ramos laterais $1-1,2 \times$ 0,5-1 mm, uma bractéola na base dos pedicelos, $0,3-1 \times 0,3-0,75 \mathrm{~mm}$, triangulares a ovadas, pubérulas, subglabras ou pubérulas somente na margem do ápice, decíduas. Pedicelo 1,5-2,5 mm compr., glabro. Flores 1,25-1,5 mm diâm., 1,25-1,75 mm compr., verdes, elipsoides ou raramente globosas, externamente glabras. Tépalas subiguais a desiguais, quando desiguais, ${ }^{1}$ Espécie aceita para publicação: Brittonia 
externas menores, externas $0,5-0,75 \times 0,5-0,75 \mathrm{~mm}$, internas $0,75-1 \times 0,75-1,5 \mathrm{~mm}$, ovadas, ápice obtuso a arredondado, margem papilosa, internamente glabras, menores que o receptáculo, $1 / 3^{-1 / 4}$ do comprimento da flor. Estames livres, $0,75-1 \times 0,5-0,6 \mathrm{~mm}$, exsertos na antese; anteras $0,3-0,4 \times 0,4-0,5 \mathrm{~mm}$, extrorsas, triangulares, ovado-triangulares ou arredondadas, glabras e ligeiramente papilosas no ápice; filetes $0,7-0,8 \times 0,5-0,6 \mathrm{~mm}$, quadráticos ou retangulares, do mesmo tamanho a ligeiramente maiores que as anteras, glabros. Estaminódios ausentes ou raramente 1 por flor, pertencentes à série IV do androceu, $0,5 \times 0,5 \mathrm{~mm}$, estiptiformes, glabros. Pistilo 1,5-1,8 mm compr., glabro; ovário 0,9-1 mm compr., elipsoide; estilete $0,7-0,8 \mathrm{~mm}$ compr., exserto na antese. Receptáculo 0,3-0,75 mm compr., glabro internamente. Frutos até 32 × $21 \mathrm{~mm}$, elipsoides, glabros. Cúpulas 3,5-5,5 mm diâm., planas a pateliformes, externa e internamente glabras, diâmetros do mesmo tamanho ou ligeiramente maiores que os pedicelos na frutificação. Pedicelo na frutificação 3,5-5,5 mm compr., liso, glabro, bractéolas decíduas.

Parátipos: BRASIL. Espírito Santo. Santa Teresa, Estação Ecológica de Santa Lúcia, 09/02/1993, fr., L. D. Thomaz 1299 (MBML); 05/05/1993, fr., L. D. Thomaz 1570 (ESA, MBML); 05/05/1993, fr., L. D. Thomaz 1571 (ESA, MBML); 09/11/1993, veg., L. D. Thomaz 1572 (ESA, MBML, SPSF); 07/02/1995, fr., L. D. Thomaz 1573 (ESA, MBML); 15/12/1992, fl., L. D. Thomaz s.n. (SPSF 18758); 11/11/2008, bot., T. D. M. Barbosa \& F. M. Alves 1012 (UEC); 11/11/2008, bot., T. D. M. Barbosa \& F. M. Alves 1013 (UEC).

Distribuição e ecologia: Mezilaurus glabriantha é restrita ao Brasil, conhecida somente para a Estação Ecológica de Santa Lúcia, município de Santa Teresa no estado do Espírito Santo (Figura 15). A espécie ocorre na sub-região Paranaense, província Floresta Atlântica Brasileira (Figura 1); característica da Floresta Atlântica de Encosta, entre 650 e 800 m de altitude.

Fenologia: Coletada com flores em dezembro e frutos em março, maio e novembro. 
Etimologia: O epíteto glabriantha é baseado em suas flores glabras em todas as estruturas.

Status de Conservação: Mezilaurus glabriantha possui distribuição restrita, conhecida apenas por seis espécimes na Estação Ecológica de Santa Lúcia, que possui, de acordo com Mendes \& Padovan (1999), cerca de 4,4 km². Por essa razão, M. glabriantha deve ser considerada, baseado nas categorias e critérios da IUCN (IUCN 2001), como "Criticamente em Perigo" (CR) (B1a+bii, B2bii).

Nome popular: desconhecido.

Importância econômica: desconhecida.

As características mais importantes para distinção de Mezilaurus glabriantha são seas inflorescências do tipo duplo racemo (dibótrio) com ramos laterais umbeliformes, raque principal pubérula e ramos laterais glabros, tépalas mais curtas que o receptáculo, $1 / 3-1 / 4$ do comprimento da flor e flores, receptáculo, estames, pistilos, frutos e cúpulas glabras.

Além de Mezilaurus glabriantha, M. navalium e $M$. revolutifolia compartilham distribuição geográfica restrita à Floresta Atlântica Brasileira. Mezilaurus navalium, uma espécie endêmica do Rio de Janeiro, apresenta lâminas foliares estreito-elípticas a oblanceoladas, 3-8,4 vezes mais longas que largas, receptáculo e filetes pubescentes. Já Mezilaurus revolutifolia, apresenta ocorrência restrita ao nordeste do Brasil e, ao contrário de M. glabriantha, possui lâminas foliares com margem ligeiramente revoluta ou raramente plana, tépalas do mesmo tamanho a ligeiramente maiores que o receptáculo, cerca de $1 / 2$ do comprimento da flor e filetes pubescentes.

Além de Mezilaurus glabriantha, no estado do Espírito Santo, pode ocorrer também $M$. crassiramea. A última espécie citada, no entanto, apresenta lâminas na face abaxial hirsutas, vilosas a lanosas, receptáculo pubescente internamente e filetes pubescentes. 
Mezilaurus glabriantha compartilha características muito semelhantes à M. itauba, porém, esta última apresenta pecíolo dilatado, ramo lateral da inflorescência pubescente a pubérulo, estames pubescentes e receptáculo internamente pubescente. Mezilaurus itauba é uma espécie característica da Amazônia, ocorrendo desde a Venezuela, Colômbia, Peru, Equador, Suriname e Guianas, até a Bolívia, norte e centro-oeste do Brasil, por outro lado, M. glabriantha é conhecido somente para a Floresta Atlântica do Espírito Santo.

A coleção de Mezilaurus glabriantha permaneceu sem identificação correta por dezessete anos, tendo sido identificada como Sloanea L. (Elaeocarpaceae), Beilschmiedia, Cryptocarya, Williamodendron cinnamomeum van der Werff ou Ocotea (Lauraceae). 


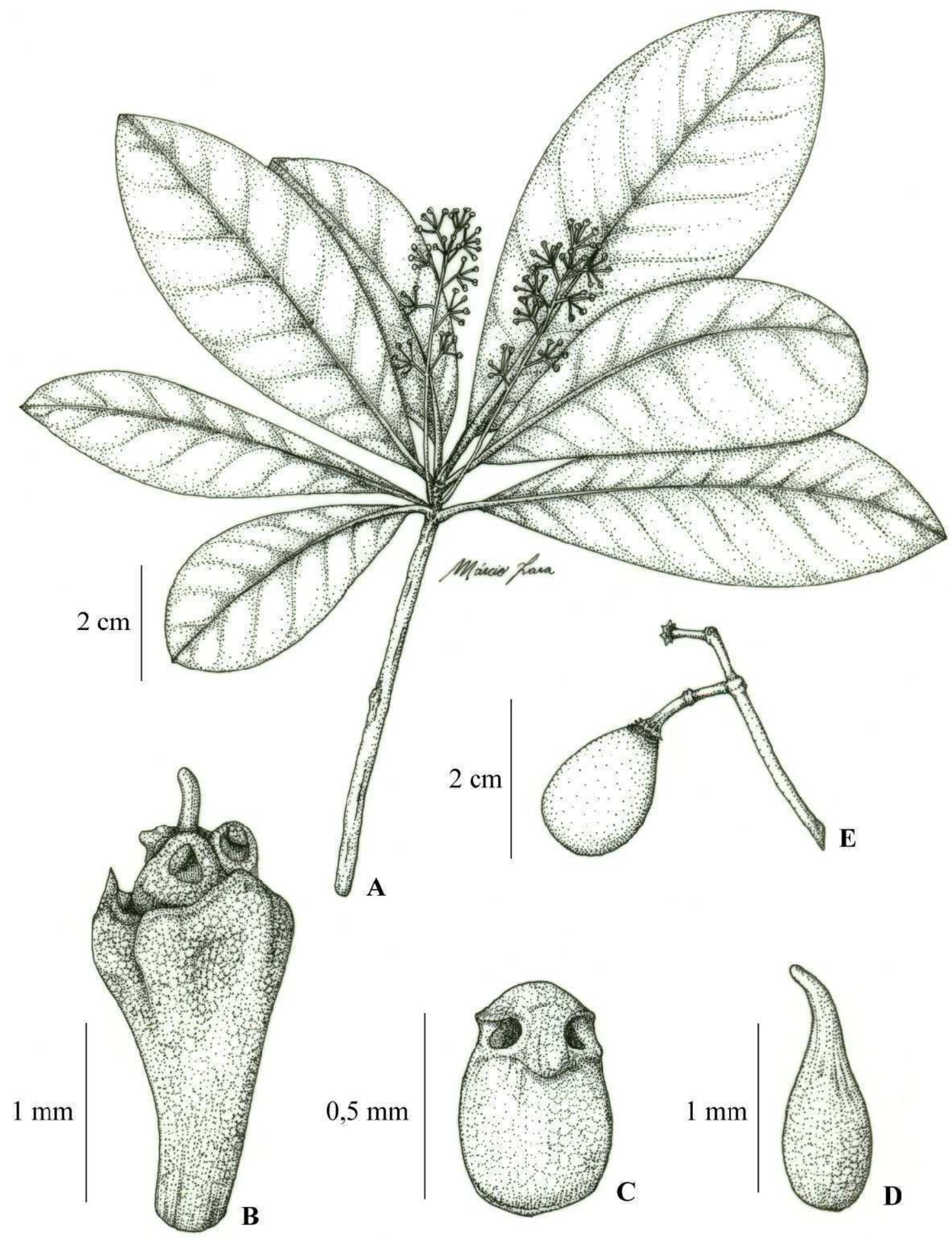

Figura 16: Ilustração de Mezilaurus glabriantha. A: ramo com flores; B: flor; C: estame; D: pistilo; E: fruto (isótipo). 
1.6. Mezilaurus introrsa F. M. Alves \& van der Werff, sp. nov. Tipo: Colômbia. Vaupes, Estación Ecológica Capurú, within $3 \mathrm{~km}$ of the north bank of Lago Taraira $\left(1^{\circ} 00^{\prime} \mathrm{S} / 69^{\circ} 49^{\prime} \mathrm{W}\right)$, 22/09/1989, fl., S. Defler 219 (holótipo, MO 6216882).

(Figura 17).

A Mezilauro itauba floribus glabris et pedicellus pubescens, tepali aequalis receptaculum, $1 / 2$ de floribus et locellis introrsum differt.

Árvores ca. $30 \mathrm{~m}$ alt. Ritidoma escamoso, cor desconhecida. Râmulos 3-5 mm diâm., cilíndricos a ligeiramente angulosos, marrom, pubescentes a pubérulos no ápice, com lenticelas conspícuas próximas do ápice; catafilos ovados a lanceolados, 4-5,5 $\mathrm{mm}$ compr., creme, seríceos. Folhas alternas, 11-16,7 × 4-6,1 cm. Lâminas elípticas, 2,2-2,6 vezes mais longas que largas, glabras a subglabras, base aguda ou decorrente, simétrica, ápice agudo a ligeiramente acuminado, margem plana, pontuações glandulares na face abaxial, muitas vezes inconspícuas. Venação ligeiramente broquidódroma, 11-18 nervuras por lado, impressa na face adaxial, proeminente na abaxial; nervuras secundárias formando um ângulo de $50-90^{\circ}$ com a primária, juntando com as suprajacentes em ângulo obtuso; terciárias reticuladas ou percorrentes, oblíquas. Pecíolo 14-24× 1,5-2,5 mm, representando $10-14 \%$ da folha, plano a ligeiramente canaliculado, pubérulo, base dilatada. Inflorescências do tipo duplo racemo (dibótrio) com ramos laterais umbeliformes, axilares, 3,9-7 cm compr., menores que as folhas, pubérulas; ramos laterais $0,8-1,3 \mathrm{~cm}$ compr., 5-7 flores por ramo lateral; pedúnculos 1,5-3,5 cm compr. Bractéolas na base dos ramos laterais não vistas, uma bractéola na base dos pedicelos, ca. $0,5 \times 0,3 \mathrm{~mm}$, triangulares, pubérulas, decíduas. Pedicelo 0,5-1 mm compr., pubérulo, tricomas não papilosos. Flores 2-2,25 mm diâm., 1,5-1,75 mm compr., cor desconhecida, depressas, externamente glabras. Tépalas iguais ou subiguais, quando subiguais, externas menores, externas ca. $1 \times 1 \mathrm{~mm}$, internas ca. $1 \times 1,5$ mm, ovadas, ápice obtuso, margem ligeiramente papilosa, internamente pubescentes, do mesmo tamanho ou ligeiramente maiores que o receptáculo, ca. $1 / 2$ do comprimento da flor. Estames 
livres, ca. $1 \times 1 \mathrm{~mm}$, inclusos na antese, raro ligeiramente excluso; anteras ca. 0,5 $\times 0,75 \mathrm{~mm}$, introrsas, triangulares, glabras frontalmente, pubescentes na face dorsal, não papilosas; filetes ca. $0,5-1 \times 0,75-1,1 \mathrm{~mm}$, quadráticos ou retangulares, do mesmo tamanho das anteras, pubescentes. Estaminódios ausentes ou raramente 1 por flor, pertencentes à série IV do androceu, ca. $0,5 \times 0,2$ mm, estiptiforme, pubescente. Pistilo ca. 1,8 mm compr., glabro; ovário ca. 0,9 mm compr., globoso; estilete ca. 0,9 mm, exserto na antese. Receptáculo ca. 0,75 $\mathrm{mm}$ compr., pubescente internamente. Frutos até $30 \times 13 \mathrm{~mm}$, elipsoides, glabros. Cúpulas ca. 5,5 mm diâm., pateliformes, externamente glabras, internamente pubescente a pubérulas, diâmetros maiores que os pedicelos na frutificação. Pedicelo na frutificação ca. $3 \mathrm{~mm}$ compr., liso, pubérulo a glabro, bractéolas decíduas.

Parátipo: COLÔMBIA. Vaupes: Estación Ecológica Capurú, within $3 \mathrm{~km}$ of the north bank of Lago Taraira ( $\left.1^{\circ} 00^{\prime} \mathrm{S} / 69^{\circ} 49^{\prime} \mathrm{W}\right), 22 / 09 / 1989$, fr., S. Defler 220 (MO).

Distribuição e ecologia: Mezilaurus introrsa apresenta distribuição restrita ao departamento de Vaupes na Colômbia, conhecida somente para a Estação Ecológica Capurú (Figura 15). A espécie está representada na sub-região Amazônica, província de Imerí (Figura 1); na floresta inundada sazonalmente, intitulada localmente como "igapó”, há $200 \mathrm{~m}$ de altitude.

Fenologia: Coletada com flores e frutos em setembro.

Etimologia: O epíteto introrsa é uma referência às anteras introrsas da espécie.

Status de conservação: A espécie é conhecida somente por duas coletas, restritas a Estação Ecológica Capurú, no departamento de Valpes, sudeste da Colômbia. Por essa razão, a espécie deve ser considerada, utilizando as categorias e critérios da IUCN (2001), como "Criticamente em perigo" (CR) (B1a).

Nome popular: desconhecido. 
Importância econômica: desconhecida.

Mezilaurus introrsa é caracterizada por apresentar lâminas foliares elípticas, glabras a subglabras, pecíolos 14-24 mm compr., representando 11-14 da folha, inflorescências do tipo duplo racemo (dibótrio) com ramos laterais umbeliformes, uma bractéola na base dos pedicelos, pedicelos pubérulos, flores globosas, glabras, tépalas do mesmo tamanho ou ligeiramente maiores que o receptáculo, ca. $1 / 2$ do comprimento da flor, anteras introrsas, filetes pubescentes e pistilo glabro.

Dentro do gênero Mezilaurus, M. introrsa e M. subcordata apresentam anteras introrsas. Mezilaurus subcordata, possui porém, pecíolos (9-) 29-70 (-75) mm compr., representa 17-29\% da folha, flores externamente pubérulas e pistilo pubérulo.

Mezilaurus introrsa é bastante semelhante à $M$. itauba, todavia, esta última espécie apresenta flores glabras (pedicelos glabros) ou pubérulas (pedicelos pubérulos), pedicelos 1-2,5 vezes o comprimento da flor, tépalas menores que o receptáculo, ${ }^{1} / 3^{-}{ }^{1} / 4(-1 / 5)$ do comprimento da flor, anteras extrorsas ou latrorsas.

A espécie pode ser confundida também com M. synandra, pois as duas compartilham flores globosas e tépalas do mesmo tamanho ou ligeiramente maiores que o receptáculo, ca. $1 / 2$ do comprimento da flor. Entretanto, ao contrário de $M$. introrsa, M. synandra apresenta flores pubérulas, pistilo pubescente e fruto pubescente no ápice. 


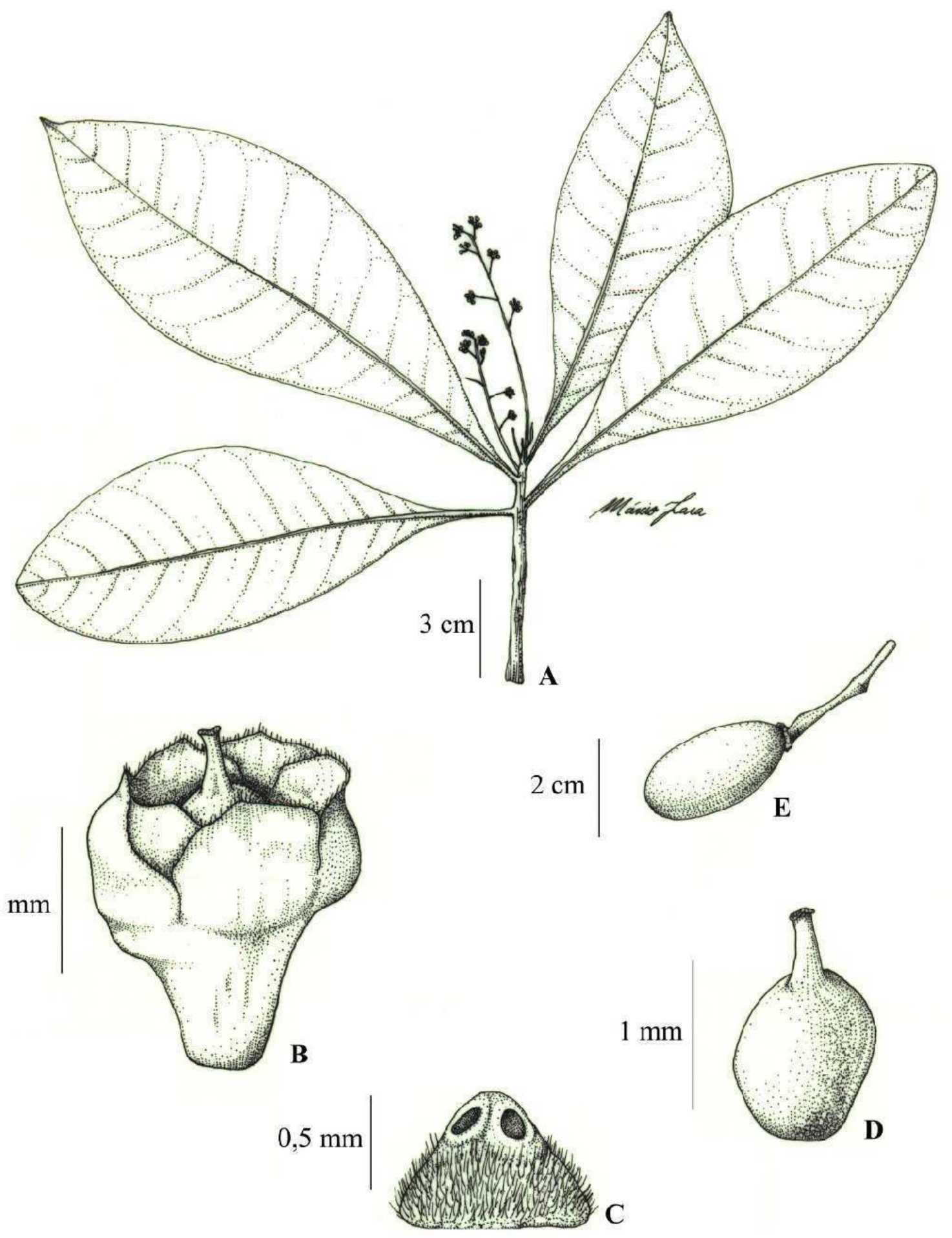

Figura 17: Ilustração de Mezilaurus introrsa. A: ramo com flores; B: flor; C: estame; D: pistilo (holótipo); E: fruto (parátipo). 
1.7. Mezilaurus itauba (Meisn.) Taub. ex Mez, Arbeiten Königl. Bot. Gart. Breslau 1: 112. 1892. Acrodiclidium itauba Meisn. in DC., Prodr. 15 (1): 86. 1864. Endiandra itauba (Meisn.) Benth. in Benth. \& Hook. f., Gen. Pl. 3 (1): 154. 1880. Silvia itauba (Meisn.) Pax in Engler \& Prantl, Nat. Pflanzenfam. Nachtr. 3 (2): 123. 1889, non Silvia itauba (Meisn.) Mez, Jahrb. Königl. Bot. Gart. Berlin 5: 107. 1889. Mezia itauba (Meisn.) Kuntze, Revis. Gen. Pl. 2: 574. 1891. Tipo: Brasil. Pará, Santarém, 04/1850, Spruce 643 [numeração correta 818] (lectótipo, escolhido por Kostermans (1938c), K; isolectótipos, B [destruído], C, E [2 exsicatas], F, G [2 exsicatas], M, P, W [destruído]). (Figura 18). = Acrodiclidium itauba Meisn. var. amarella Meisn. in DC., Prodr. 15 (1): 86.1864 . Tipo: Brasil. Pará, Santarém, 07/1850, Spruce 646 [numeração correta 965] (lectótipo, designado aqui, K; isolectótipos, B [destruído], BM, C, E [2 exsicatas], G [2 exsicatas], M, OXF, P [3 exsicatas], W [destruído]).

= Oreodaphne hookeriana Meisn. in DC., Prodr. 15 (1): 231. 1864. Tipo: Brasil. Pará, Santarém, Mayacá, 02/1950, Spruce 669 (lectótipo, designado aqui, K; isolectótipos P [2 exsicatas]).

= Mezilaurus anacardioides (Spruce ex Meisn.) Taub. ex Mez, Arbeiten Königl. Bot. Gart. Breslau 1: 112. 1892. Acrodiclidium anacardioides Spruce ex Meisn. in DC., Prodr. 15 (1): 86. 1864. Misanteca anacardioides (Spruce ex Meisn.) Benth. in Hook. f., Icon. pl. 13 (3): 46.1878. Silvia anacardioides (Spruce ex Meisn.) Mez, Jahrb. Königl. Bot. Gart. Berlin 5: 108. 1889. Mezia anacardioides (Spruce ex Meisn.) Kuntze, Revis. Gen. Pl. 2: 574. 1891. Tipo: Venezuela. San Carlos del Rio Negro, 04/1853, Spruce 2961 (lectótipo, designado aqui, K [2 exsicatas]; isolectótipos, BM, BR, E, G [3 exsicatas], OXF, P [2 exsicatas], RB).

= Silvia polyantha Mez, Bull. Herb. Boissier 5 (2): 233. 1905. Tipo: Brasil. Amazonas, Moura, prope Rio Negro, 01/1902, Ule 6055 (lectótipo, escolhido por van der Werff (1987), B [destruído]; lectótipo designado aqui, K; isolectótipos, F, G, L, RB). 
= Silvia rondonii Mez \& Hoehne in Mez, Bot. Arch. 6: 230. 1924. Tipo: Brasil. Mato Grosso, Três Buritis, 05/1918, Kuhlmann 1976 (lectótipo, designado aqui, SP; isolectótipos, R, RB).

= Mezilaurus micrantha van der Werff, Ann. Missouri Bot. Gard. 74 (1): 170. 1987. Tipo: Brasil. Amazonas, Manaós, Reserva Ducke, 09/03/1966, Rodrigues \& Coelho 7555 (holótipo, NY; isótipo, INPA). sin. nov.

$=$ Mezilaurus opaca Kubitzki \& van der Werff in van der Werff, Ann. Missouri Bot. Gard. 74 (1): 171. 1987. Tipo: Peru. Loreto, Provincia Requena, Distrito Jenaro Herrera, 26/08/1976, Revilla 1226 (holótipo, MO; isótipos, AAU, HBG [2 exsicatas]). sin. nov.

= Mezilaurus palcazuensis van der Werff, Ann. Missouri Bot. Gard. 74 (1): 173. 1987. Tipo: Peru. Cerro de Pesco, Palcazu Valley, 07/12/1984, Hartshorn et al. 2691 (holótipo, MO 3285804; isótipo, MO 3592193). sin. nov.

= Mezilaurus campaucola van der Werff, Novon 13 (3): 345. 2003. Tipo: Peru. Amazonas, Condorcanqui Province, Distrito El Cenepa, Comunidad de Tutino, Cerro Tutino, 24/06/1997, Vásquez et al. 24170 (holótipo, MO; isótipos, K, NY, US). sin. nov.

Árvores ou arvoretas, ocasionalmente arbustos até $45 \mathrm{~m}$ alt. Ritidoma escamoso ou em placas, marrom-avermelhado. Râmulos 2,5-7 mm diâm., cilíndricos, marrom-avermelhados a quase pretos, pubescentes a pubérulos no ápice, com lenticelas conspícuas próximas do ápice; catafilos ovados a lanceolados, 3-10 mm compr., amarelos, dourados ou creme, pubescentes a seríceos. Folhas alternas, 3,8-26 × 1,5-8,1 (-8,5) cm. Lâminas elípticas a obovadas, raro estreito-elípticas ou ovadas, 1,5-2,9 $(-3,7)$ vezes mais longas que largas, glabras a subglabras, raro pubérula na base, base aguda, cuneada ou decorrente, simétrica ou raro ligeiramente assimétrica, ápice obtuso, arredondado, agudo, acuminado ou raramente retuso ou emarginado, margem plana ou ligeiramente revoluta, principalmente na base, pontuações glandulares na face abaxial, muitas vezes inconspícuas. Venação ligeiramente broquidódroma, 6-22 (-25) nervuras por lado, 
impressa a proeminente na face adaxial, proeminente na abaxial; nervuras secundárias formando um ângulo de $50-90^{\circ}$ com a primária, juntando com as suprajacentes em ângulos agudos a retos, terciárias reticuladas ou percorrentes, oblíquas. Peciolo 4-35 × 1,5-4 mm, representando 5-22 ($25) \%$ da folha, plano a ligeiramente canaliculado, pubérulo, base dilatada. Inflorescências do tipo duplo racemo (dibótrio) com ramos laterais umbeliformes, raro alguns ramos laterais laxos, axilares ou próximas ao ápice dos ramos, 3-11 cm compr., do mesmo tamanho a menores que as folhas, raramente maiores, pubérulas; ramos laterais $0,5-2,5 \mathrm{~cm}$ compr., 3-14 flores por ramo lateral; pedúnculos 0,8—4,7 cm compr. Bractéolas na base dos ramos laterais $1-1,25 \times 0,5-0,75$ $\mathrm{mm}$, uma bractéola na base dos pedicelos, $0,8-1 \mathrm{~mm}$ compr., 0,3-0,4 $\mathrm{mm}$ larg., triangulares, pubescentes a pubérulas, glabras ou pubérulas somente no ápice, decíduas. Pedicelo 0,5-6 mm compr., pubescente a pubérulo ou raramente glabro, tricomas não papilosos. Flores 1,5-2,5 mm diâm., 1,1-2,5 mm compr., amarelas a verdes, ligeiramente elipsoides a globosas, externamente pubescentes a pubérulas ou subglabras a glabras, tricomas não papilosos. Tépalas iguais ou desiguais, quando desiguais, externas menores, externas $0,25-0,75 \times 0,5-1 \mathrm{~mm}$, internas $0,4-1 \times$ 0,5-1 mm, ovadas, ápice obtuso a arredondado, margem papilosa, internamente pubescentes, menores que o receptáculo, $1 / 3^{-1} / 4(-1 / 5)$ do comprimento da flor. Estames livres, $0,6-1,75 \times 0,5-$ $1,25 \mathrm{~mm}$, exsertos na antese, raro no mesmo nível das tépalas; anteras $0,3-1 \times 0,3-1 \mathrm{~mm}$, extrorsas ou latrorsas, triangulares ou arredondadas, glabras frontalmente, pubescentes na face dorsal, papilosas no ápice; filetes $0,4-0,75 \times 0,4-1,25 \mathrm{~mm}$, quadráticos ou retangulares, do mesmo tamanho a maiores que as anteras, raramente menores, pubescentes. Estaminódios ausentes ou raramente presente 1 ou 2 por flor, representando as séries IV ou II e IV do androceu, 0,75-1 × 0,25-0,5 mm, clavados, papilosos, filódio pubescentes. Pistilo 1-1,8 mm compr., glabro; ovário $0,5-1,1 \mathrm{~mm}$ compr., ovoide a elipsoide; estilete $0,4-0,9 \mathrm{~mm}$ compr., exserto na antese. Receptáculo 0,5-1 mm compr., pubescente internamente. Frutos até $24 \times 15 \mathrm{~mm}$, elipsoides a obovoides, glabros. Cúpulas 3,5-5,5 mm diâm., planas a pateliformes, externa e 
internamente pubérulas a glabras, diâmetros iguais ou maiores que os pedicelos na frutificação. Pedicelo na frutificação 2-8 mm compr., liso, pubérulo a glabro, bractéolas decíduas.

Material examinado: BOLÍVIA. Beni. Prov. Vaca Diéz, Reserva Ecológica El Tigre, a 40 km al este de Riberalta, sobre lá carretera a Guayaramerín $\left(10^{\circ} 58^{\prime} 56^{\prime}\right.$ 'S $\left./ 65^{\circ} 43^{\prime} 08^{\prime \prime} \mathrm{W}\right), 03 / 06 / 2006$, M. Toledo et al. 2093 (LPB). La Paz. Franz Tamayo, Parque Nacional y Área Natural de Manejo Integrado Madidi (14²5'23'S/6755'26''W), 18/06/2003, veg. A. Araujo et al. 507 (LPB).

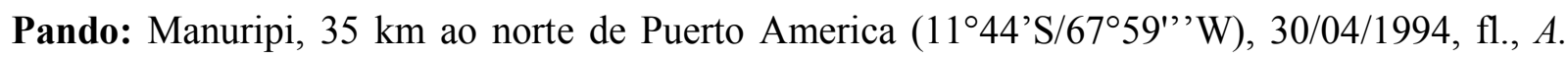
Jardim 587 (E, K, LPB); San Francisco, km 50 Cobija a Puerto Rico, 28/05/1977, fr., E. Meneces 626 (INPA, K, LPB); Villa Marieta, Cam. Extrema, 24/06/1978, veg., $R$. Dominguez \& H. Polanco 729 (INPA); km 17 Cobija a Puerto Rico, 16/05/1977, E. Meneces 601 (MG); Provincia Abuná, Comunidad San Pedro, a $45 \mathrm{~km}$ al suroeste de Santa Rosa en dirección a Cobija $\left(10^{\circ} 52^{\prime} 19,4^{\prime}\right.$ 'S $/ 67^{\circ} 37^{\prime} 00,3$ '’W), 06/05/2000, veg., J. Balcazar et al. 1709 (LPB). BRASIL. Acre: BR-317 km 68, margem direita, Area de Estudos Florestais/FUNTAC, 20/04/1990, fr., $R$. Saraiva \& I. F. Rego 305 (NY); Upper Rio Jurupary, 15/07/1933, fl., fr., B. A. Krukoff 5221 (K, NY, RB); Cruzeiro do Sul, Serra da Moa, Rio Moa, 6 km. above school, 25/04/1971, veg., G. T. Prance et al. 12450 (INPA, NY [2 exsicatas], R); near mouth of Rio Macauhan, Tributary of Rio Yaco $\left(9^{\circ} 20^{\prime} \mathrm{S}, 69^{\circ} \mathrm{W}\right), 08 / 08 / 1933$, B. A. Krukoff 5317 (BM, G, K [2 exsicatas], M, NY, U [2 exsicatas]); Xapuri, 06/04/2000, fl., fr., I. L. Franke et al. 35 (IAN). Ser. Cachoeira, Col. Sao Luis, Sucam 37. Plant collected approx 10 min from start of trail NW of house, 25/07/1989, fr., K. A. Kainer et al. 87 (NY). Amapá: Camaipi, Reserva da Embrapa, 08/09/1983, S. Mori et al. 15932 (K, NY); Contagem, entre Porto Platon e Serra do Navio, 10/10-15/12/1976, veg., N. A. Rosa 1357 (MG); Estrada entre Planalto e Braço, 10/04/1969, fl., N. T. Silva 1845 (IAN, NY). Amazonas: Alto rio Negro, próximo a boca do rio Branco, ilha do Gavião, 13/04/1967, fr., $W$. Rodrigues \& L. Coelho 8352 (INPA); Baixo Rio Negro, Acajatuba, 22/03/1941, fl., A. Ducke 681 
(R, K, MG, NY, IAN); Between Paraná da Floresta and the mouth of the Rio Branco

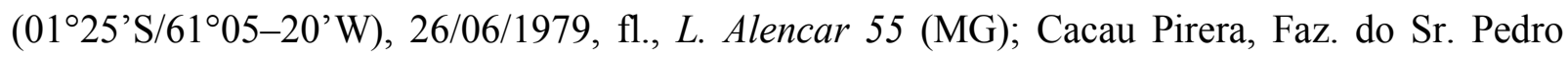
Cordeiro, 04/1977, fl., fr., J. M. Albuquerque 3 (INPA); Carauari, Rio Juruá, Poço Mungubal, 32 km do Porto Gavião, 15-26/10/1980, veg., P. Lisboa et al. 1713 (MG); Carauari, NEJ I, 06/1980, veg., A. S. L. da Silva et al. 892 (MG); Canundê, Rio Negro, 27/04/1948, fl., G. A. Black 2397 (IAC, IAN, RB); entre Paraná da Floresta e boca do Rio Branco, praia do Gavião, 26/06/1979, L. A. Maia et al. 55, fl., (INPA); estrada Manaus-Porto Velho, Rio Castanho, estrada para Careiro, 10/07/1972, fl., M. Silva et al. 336 (INPA, RB); Humaitá, rodovia transamazônica, 4 km, 03/11/1977, veg., H. Filho \& L. M. Silva 65 (INPA); Humaitá, 1 km da estrada de Lábrea, 12/11/1977, veg., H. Filho \& L. M. Silva 28 (INPA); Itaubal, Rio Aracá, sub-afl. do R. Negro, 26/10/1952, fr., R. L. Froés \& G. Addison 29101 (IAN); Manacapuru, lago da Aminga, Paraná do Jacaré, 19/03/1979, veg., D. Coelho et al. s.n. (INPA); South of Iguapó-Açu, Manaus-Porto Velho Highway, km. 246, 4 km, 14/03/1974, veg., G. T. Prance et al. 20509 (MG, NY, R). Manaus, Reserva ZF3, BR 174, km 63, 19/08/2004, fl., A. C. A. Oliveira et al. 362 (INPA); ZF2, 14/09/1988, fl., J. Aluisio s.n. (INPA); Reserva ZF2, BR 174, km 50, 25/09/2004, fr., A. C. A. Oliveira et al. 315 (INPA); ZF2, árvore $\mathrm{n}^{\circ}$ 148, 14/09/1988, fl., s.c. s.n. (INPA); igarapé do Acará, 27/04/1988, fr., J. F. Ramos 1876 (INPA, K, MG, MO, NY, SP); Reserva Florestal Ducke, 29/07/1976, fr., L. Q. Reis s.n. (INPA); estrada Manaus-Itacoatiara, km 26, Reserva Florestal Ducke, 07/05/1976, veg., Roberto s.n. (INPA); 30/06/1976, veg., F. Mello \& J. Ramos s.n. (INPA); 21/07/1976, fl., F. Mello \& J. Ramos s.n. (INPA); 29/09/1976, veg., F. Mello s.n. (INPA); Reserva Florestal Ducke, 21/06/1966, veg., W. Rodrigues \& Osmarino 7920 (INPA); 15/06/1994, fr., J. E. L. S. Ribeiro \& P. A. C. L. Assunção 1320 (INPA, MO, G); 14/03/1968, fl., L. Coelho \& D. Coelho s.n. (INPA); 22/06/1966, veg., W. Rodrigues \& Osmarino 8138 (INPA); 04/07/1966, veg., W. Rodrigues \& Osmarino 8119 (INPA); 24/08/1976, veg., Adair s.n. (INPA); 01/06/1976, veg., Lourival s.n. (INPA); 23/08/1968, fl., J. Aluísio 110 (INPA); 10/03/1973, veg., 
K. Kubitzki et al. 74-17 (B, INPA); Reserva Ducke, 12/03/1969, fr., J. Elias \& Aloisio 461 (INPA); estrada Manaus-Itacoatiara, Reserva Florestal Ducke, 06/10/1976, veg., Adair s.n. (INPA); 09/07/1976, veg., Haroldo s.n. (INPA); 10/06/1966, veg., W. Rodrigues \& Osmarino 7902 (INPA); 10/06/1976, veg., Adair s.n. (INPA); 09/04/2008, veg., F. M. Alves 523 (ESA); estrada Manaus-Caracaraí, km 39, 23/08/1977, veg., F. Mello \& J. Ribamar 21 (INPA); Reserva biológica do INPA, BR 174, km 57, 28/09/1976, veg., C. D. A. Mota 734 (INPA); distrito agropecuário SUFRAMA, BR 174, km 72, 6 km da BR, 25/05/1985, veg., M. J. R. Pereira s.n. / INPA/WWF 2303.19995 (INPA); Estrada Manaus-Porto Velho, estrada entre os rios Castanho e Tupana, 13/07/1972, fr., M. F. Silva et al. 720 (INPA); Distrito Agropecuário, Reserva 1501 (km 41) da WWF/INPA Projeto da Dinâmica Biológica dos Fragmentos Florestais, 10/07/1989, fl., $N$. M. L. da Cunha et al. 226a (INPA, NY, K); Reserva Florestal Ducke (Manaus-Itacoatiara, km 26), 11/03/1994, bot., A. Vicentini \& C. F. da Silva 421 (INPA, SP, K); Estrada ManausItacoatiara, km 26, Reserva Florestal Ducke, 29/06/1976, bot. F. Mello \& J. Ramos s.n (INPA); Reserva Florestal Ducke, Manaus-Itacoatiara, km 26, 11/07/1994, fl., A. Vicentini \& P. A. C. L. Assunção 593 (INPA, MG, MO, NY, RB [2 exsicatas] SP, U); Reserva 1501 do PDBFF, 90 km NNE de Manaus, 03/01/1993, veg., A. A. de Oliveira et al. 1289 (SPF); Reserva 1501 do PDBFF, 90 km NNE de Manaus, 03/01/1993, veg., A. A. de Oliveira et al. 1287 (SPF); Reserva 1501 do PDBFF, 90 km NNE de Manaus, 03/01/1993, fr., A. A. de Oliveira et al. 1084 (SPF); Reserva 1501 do PDBFF, 90 km NNE de Manaus, 02/01/1993, veg., A. A. de Oliveira et al. 1060 (SPF); Reserva 1501 do PDBFF, 90 km NNE de Manaus, 03/01/1993, veg., A. A. de Oliveira et al. 1488 (SPF); Reserva 1501 do PDBFF, 90 km NNE de Manaus, 03/01/1993, veg., A. A. de Oliveira et al. 1498 (SPF); Reserva 1501 do PDBFF, 90 km NNE de Manaus, 03/01/1993, veg., A. A. de Oliveira et al. 1604 (SPF); Reserva 1501 do PDBFF, 90 km NNE de Manaus, 04/01/1993, veg., A. A. de Oliveira et al. 1901 (SPF); Praia Grande, Rio Negro, 16/07/1981, fl. fr., W. Mantovani \& D. M. S. Rocha 12746 (UEC); terreno da SIDERAMA, 05/05/1973, veg., A. Loureiro et al. s.n. 
(INPA); Nova Olinda do Norte, rio Canumã, 11/1976, veg., O. P. Monteiro 1302 (INPA); Parintins, 11/03/1946, fr., J. M. Pires \& G. A. Black 1147 (IAN); Paxiubinha, Rio Tefé, 14/06/1950, fr., R. L. Froés 26565 (IAN); Presidente Figueiredo, área das trilhas botânicas da cachoeira da onça, 05/2000, C. A. C. Ferreira \& J. F. Ramos 12620 (INPA); Posto Indígina Genipapo, rio Demeni, afluente do rio Negro, 12/10/1952, fr., R. L. Froés 28898 (IAN, RB); Região do Rio Negro, Canundê, 27/04/1948, veg., G. A. Black 48-2397 (INPA); Rio Negro, Ilha do Gavião, at the mouth of the Rio Branco, 10/06/1989, fl., fr., S. Mori et al. 20458 (INPA, NY); Rio Negro. Rio Marié, ca. 30 km above mouth, Village Macobeta, 09/09/1979, veg., K. Kubitzki et al. 79-192 (INPA, M, NY); Rio Negro, rio Tea $40 \mathrm{~km}$ above mouth, Village Bacuri, 09/10/1979, fr., K. Kubitzki et al. 79-237 (INPA, M, MG, NY). Mato Grosso: Aripuanã, estrada para o aeroporto, 02/06/1979, veg., M. G. Silva \& C. Rosário 4756 (HAMAB, INPA, MG); Santa Carmem, faz. Jamanchim 11/07/1995, veg., M. Macedo et al. s.n. (INPA, UFMT). Pará: Almeirim, estrada da Água Azul, 21/06/1979, fr., M. R. Santos 649 (IAN, INPA, MG, NY); 08/11/1979, fr., N. T. Silva 5198 (INPA, MG [2 exsicatas]); Breu Branco, Fazenda Água Azul, 19/07/2005, veg., S. M. Nascimento 9 (IAN); Estrada Santarém-Cuiabá, km 67, Reserva Florestal do IBDF, 05/03/1979, veg., M. R. Cordeiro et al. 1599 (IAN); Estrada Santarém-Cuiabá, BR 165, km 190, distrito de Rurópolis, 16/10/1975, veg., L. P. F. 315 (INPA); Faro, 21/06/1926, fl., A. Ducke s.n. (INPA, K, RB, U); Frechal, Médio Tapajós, 27/06/1918, fr., A. Ducke s.n. (BM, G, MG, P, R, RB, U); Itupiranga, às margens do rio Tocantins, 17/04/1981, fr., W. Rodrigues \& $L$. Coelho 10295 (INPA, MG); Estrada de São Miguel, 15/07/1970, fl., N. T. Silva 3238 (INPA); Baixo Tapajós, 07/04/1924, fl., J. G. Kuhlmann 1925 (INPA, K, RB, U); Marabá, Serra dos Carajás, 15/03/1984, fl., A. S. L. da Silva et al. 1830 (INPA, MG, NY); Rio Jarí, Planalto de Monte Dourado, 09/06/1968, fr., E. Oliveira 4847 (IAN); Rio Jari, Planalto do Monte Dourado, 28/08/1968, fr., E. Oliveira 4804 (IAN); Região do Jarí, Estrada do Munguba, km 15, 21/08/1970, fr., N. T. Silva 3278 (IAN); Região do Rio Jarí, Igarapé Tinguelin, 16/08/1969, fr., $N$. 
T. Silva 2704 (IAN); Rio Jarí, Monte Dourado, Planalto A, 30/09/1968, fr., N. T. Silva 1041 (IAN, NY); 03/09/1968, fr., E. Oliveira 4824 (IAN); 31/08/1968, fr., E. Oliveira 4818 (IAN); Santarém, 27/03/1924, fl., fr., J. G. Kuhlmann 1782 (INPA, K, RB, U); Santarém, Distrito de Rurópolis (Estrada Santarém-Cuiabá, BR 165, km 174), 24/10/1975, veg., L. P. F. 350 (INPA); Santarém, 25/03/1926, fl., A. Ducke s.n. (RB, U); Belterra, 24/06/1947, fr., G. A. Black 47-930 (IAC [G. A. Black 930], IAN, INPA, NY, U); Santarém, Belterra, Zona Branco, BR 165, km 82, 12/09/1974, veg., Didi 082.17.04 (IAN); Santarém, Belterra, Zona Fé em Deus, BR 165, km 72, 20/08/1974, veg., Argemiro s.n. (IAN); Belterra, 25/07/1947, fr., G. Black 47-1089 (IAC, IAN); Santarém, Belterra, 24/10/1975, veg., Erly 1741711 (IAN); Santarém, Belterra, 29/09/1975, veg., Erly 0941705 (IAN); Santarém, Belterra, coleção do IBDF, 06/10/1975, veg., Erly 11917 07 (IAN); Santarém, Belterra, coleção do IBDF, 16/10/1975, veg., Erly 1901710 (IAN); Santarém, Belterra, coleção do IBDF, 02/10/1975, veg., Erly 1171706 (IAN); Santarém, Belterra, coleção do IBDF, 11/10/1975, veg., Erly 1471709 (IAN); Santarém, Belterra, Zona Branco, BR 165, km 80, 06/09/1974, veg., Argemiro s.n. (IAN); Santarém, Belterra, Zona Branco, BR 165, km 79, 02/09/1974, veg., Raimundo s.n. (IAN); Santarém, Distrito de Belterra, zona Andorinha, 06/10/1975, L. P. F. 283 (INPA); Santarém, Distrito de Belterra, zona Andorinha, 02/10/1975, veg., L. P. F. 275 (INPA); Santarém, Distrito de Belterra, zona São Jorge, 29/09/1975, veg., L. P. F. 261 (INPA); Santarém, 16/03/1953, R. L. Froés \& J. B. Filho 29546 (IAN, RB); Santarém, Distrito de Rurópolis, Estrada Santarém-Cuiabá, BR 165, km 174, 24/10/1975, veg., L. P. F. 350 (INPA); Santarém, 07/07/1918, fr., A. Ducke s.n. (MG, R); Santarém, 15/10/1872, veg., J. B. Rodrigues s.n. (R); Serra dos Carajás, 5 km west of AMZA (604'S/50¹0’W), 15/05/1982, veg., C. R. Sperling 5699 (K, MG, NY); Santarém, 11/184903/1850, R. Spruce s.n. (K); Santarém, Rio Cuminá-Mirim, Capintuba, 26/07/1906, fr., A. Ducke s.n. (MG); Santarém, Estrada Santarém-Cuiabá km 67, Reserva Florestal do IBDF, 02/03/1979, veg., M. R. Cordeiro et al. 1566 (IAN); Santarém, Estrada Santarém-Cuiabá km 67, Reserva 
Florestal do IBDF, 13/02/1979, veg., M. R. Cordeiro et al. 1435 (IAN); Santarém, Estrada Santarém-Cuiabá Km 67, Reserva Florestal do IBDF, 22/02/1979, vegetativo, M. R. Cordeiro et al. 1497 (IAN); Santarém, Flona Tapajós, BR 163, Santarém-Cuiabá, km 83, 16/10/2001, veg., R. N. S. Feitosa 75 (IAN); Santarém, Flona Tapajós, BR 163, Santarém-Cuiabá, km 83, 11/10/2001, veg., R. N. S. Feitosa 73 (IAN); Santarém, BR 163, Santarém-Cuiabá, km 83, 27/09/2001, veg., R. N. S. Feitosa 16 (IAN); Praia Grande, margem direita do rio Negro, no SW das ilhas Anavilhanas, 31/07/2000, fl., fr., A. Vicentini 1685 (INPA, MG); Serra dos Carajás, 2 km west of AMZA $\left(6^{\circ} 04^{\prime} \mathrm{S} / 50^{\circ} 08^{\prime} \mathrm{W}\right), 13 / 05 / 1982$, fl., C. R. Sperling et al. 5614 (F, K, MG, NY); 2 km west of AMZA, 25/05/1982, fr., C. R. Sperling et al. 5828 (MG, NY); setor N-4, 25/03/1977, fl., M. G. Silva \& R. Bahia 2909 (MG, NY); Serra Norte, 21/04/1970, fl., M. Silva 2666 (MG); Carajás, a margem da PA 275, km 105, 16/05/1987, fl., C. M. Araújo 100 (MG); Serra Norte, ca 20 km N of AMAZ Exploration Camp., 18/10/1977, fr., C. C. Berg et al. 616 (K, MG, NY, RB); Parauapebas, Flona de Carajás, Canga da Serra Sul, 26/06/2009, fl., R. D. Ribeiro et al. 1205 (MG, RB); Serra do Norte, Núcleo 3, 08/07/1985, fr., L. P. C. Morellato-Fonzar \& N. Rosa 18382 (UEC); Tucuruí, Breu Branco, km 40 south of Represa Tucuruí along highway BR 422, 17/03/1980, fl., T. Plowman et al. 9678 (HRB, K, MG, NY); Tucuruí, Bosque dos escoteiros, 08/03/1982, fl., fr., L. Coêlho 1873 (INPA, NY); Tucuruí, BR 423, 15/03/1981, fl., U. N. Maciel \& C. S. Rosário 550 (MAC, MG, NY); Tucuruí, Zona das Pedras, Margem direita do Rio Tocantins, 10/04-29/05/1981, veg., U. N. Maciel et al. 600 (MG); Villa Braga, Rio Tapajós, 25/05/1923, fl., A. Ducke s.n. (RB, K, P, U, G [A. Ducke 5317]). Rondônia: Costa Marques, BR 429, km 30, 24/05/1982, fl., fr., M. G. Silva \& C. Rosário 5860 (INPA, MG); Ji-Paraná, Gleba G, km 03, 29/03/1983, fl., M. G. Silva 6056 (MG, NY); Porto Velho, Rio Jumari, 18/01/198911/02/1989, fl. fr., U. N. Maciel \& C. S. Rosário 1703 (MG); Presidente Médici, Rodovia 429, km 15, 27/08-25/09/1984, veg., U. N. Maciel et al. 1399 (MG); Vilhena, BR Vilhena-Porto Velho, 26/07/2000, fr., A. Vicentini 1673 (INPA, MG); Vilhena, Serra dos Parecis, 10/05/1984, 
fl. fr., J. U. Santos et al. 743 (MG); Vilhena, estrada para Colorado do Oeste, a $20 \mathrm{~km}$ de Vilhena, Serra dos Parecis, 11/05/1985, veg., J. U. Santos et al. 775 (MG); Vilhena, estrada velha para Colorado do Oeste, a $20 \mathrm{~km}$ de Vilhena, Serra dos Parecis, 11/05/1984, veg., J. U. Santos et al. 776 (MG); Vilhena, 66 km oeste de Vilhema, 03/09/1963, fr., B. Maguire et al. 56549 (K, NY, U); Ouro Preto do Oeste, Reserva Biológica de Ouro Preto do Oeste, BR 364, s.d., veg., J. Lima et al. 1015 (INPA). Roraima, Perto da Boca do Rio Ajarani com o Rio Branco, 28/04/1974, veg., J. M. Pires et al. 14385 (IAN). Local indeterminado. Obidos, Mata de terra firme do Portal azul, 01/02/1918, veg., A. Ducke s.n. (MG). COLÔMBIA. Amazonas, Araracuara, Villa Azul, resguardo indígena Muinanae ( $\left(0^{\circ} 32^{\prime} \mathrm{S} / 71^{\circ} 6^{\prime \prime} \mathrm{W}\right), 26 / 02 / 1993$, veg., $A$. Duque et al. 856 (COL); carretera Cenyro-Puerto Arturo "Paso de Frijol", 25/03/1985, veg., Palacios, P. A. et al. 538 (COL). Guaviare, Rio Inirida, 06/1976, T. A. Roa 424 (INPA, COL). EQUADOR. Province Sucumbios, Reserva de Producción Faunística Cuyabeno, 1 km north of Laguna Grande, Hectare-plot no 1, 01/04/1988-01/04/1990, fl., R. Valencia et al. 67359 (BM); Zamora-Chinchipe, in the vicinity of the mining camp at the Rio Tundaime (03 '34'44',S/78²4'11'’W), 09/11/2004, fl., H. van der Werff et al. 19445 (MO). GUIANA FRANCESA. s.1., 1862, veg., M. Mélinon 613 (P); s.1., 1862, fl., M. Mélinon 619 (P); s.1., 1863, fl., M. Mélinon 46 (P); Maroni, s. d., fl., M. Melinon s.n. (P); Maroni, 1862, fl., M. Melinon s.n. (P); Piste de Saint-Elie-interfluve Sinnamary/Counamama, 12/11/1991, veg., D. Sabatier \& M. F. Prevost 3929 (B); 14/04/1987, veg., D. Sabatier \& B. Riera 1729 (B); Piste de Saint-Elieinterfluve Sinnamary/Counamama, 17/08/1987, veg., B. Riera \& D. Sabatier 1315 (B); Rivière Grand Inini-Bassin du Maroni, 10/07/1990, veg., D. Sabatier \& M. F. Prevost 3166 (B); Station des Nouragues-Bassin de L' Arataye, 06/07/1989, veg., D. Sabatier \& M. F. Prevost 2607 (B). PERU. Huánuco. Prov. Puerto Inca, Dtto. Yuyapichis, 01/12/1989-15/12/1989, veg., Flores \& Tello 6 (K). Loreto. Prov. Requena, ad flumen Ucayali, silva uda aequinotiali, arbre 7-58, 08/09/1976, fl., L. Bernard s.n. (MBM 184371); Prov. Requena, ad flumen Ucayali, silva uda 
aequinotiali - árvore 7/64, 08/09/1976, L. Bernardi 16227 (G, MBM); Provincia Maynas, Alpahuayo, $26 \mathrm{~km}$ along road Iquitos-Nauto, 24/08/1988, fl., H. van der Werff et al. 10263 (MO); Maynas Province, Iquitos, Allpahuano, Estación Experimental del Instituto de Investigaciones de la Amazonia Peruana (IIAP), 12/1990, fr., R. Vásquez \& Jaramillo 15759 (MO); Requena, Jenaro Herrera - árvore 7/58, 08/09/1976, fl., L. Bernardi s.n. (G [3 exsicatas]); Requena, Jenaro Herrera - árvore 7/58, 28/08/1974, bot., M. Diaz 166-A (G); Requena, Jenaro Herrera, árvore 7/64, 05/10/1981, fl., R. Spichiger \& P.-A. Loizeau 4174 (G); Prov. de Maynas, Santa Cecilia, Rio Maniti, ubicado a 1 hora $30 \mathrm{~min}$. de Iquitos bajando o Amazonas en deslizador, 11-14/12/1985, fr., J. R. Trigoso 620 (K). Pasco. Cerro de Pasco Departament, Palcazu Valley, 16/05/1986, fl., G. Hartshorn \& J. Quijano 2945 (F, MO, U); 14/06/1986, veg., G. Hartshorn et al. 2920 (U); 06/06/1986, fl., G. Hartshorn \& J. Quijano 2975 (MO); Prov. Oxapampa, Cabeza de Mono, Rio Iscozacin, $10 \mathrm{~km}$ SW do Iscozacin, Palcazu Valley, 12/06/1983, fl., A. Gentry et al. 41945 (MO). SURINAME. Sirowa, Sectie 0, s.d., veg., Mei 45 (B [Stahel 320], K, U); s.1., 06/05/1918, fl., B. W. 3829 (K, U); s.1., Sectie 0, 08/11/1920, fr., B. W. 4790 (U); s.1., 06/09/1916, B. W. 2398 (U); Bosreservaat, 31/07/1917, fl., B. W. 3088 (COL, U [2 exsicatas]); Brokopondo District. 4 km E of village Brownsweg, 04/01/1967, veg., J. van Donselaar 2906 (U); 6 km E of village Brownsweg, 19/02/1966, veg., J. van Donselaar 3177 (U); 8 km ESE of village Brownsweg, 21/01/1965, veg., J. van Donselaar 2043 (U). VENEZUELA. Amazonas. San Carlos de Rio Negro-Solano, a unos $4 \mathrm{~km}$ de San Carlos (1'55'30''S/6702'04'’W), 25/03/2000, veg., P. E. Berry \& G. Aymard 7197 (VEN); 11 km northeast of São Carlos del Rio Negro (1 ${ }^{\circ} 58^{\prime}$ S/67³’W), 13/11/1977, veg., R. Liesner \& J. Hall 3444 (VEN); Territorio Federal do Amazonas, San Carlos del Rio Negro, Sabana y Selva alrededores del aeropuerto, 17-18/04/1970, veg. J. A. Steyermark \& G. Bunting 102781 (VEN); s.l., 02/06/1942, veg., L. Williams 15726 (VEN); Estación Experimental de Sta. Bárbara del Orinoco, 1-2 km al sur del Trapichote, 22/02-02/03/1976, veg., P. Berry \& L. Chesney 2053 
(VEN). LOCAL INDETERMINADO. s.1., s.d., veg., R. Spruce 19 (K); s.1., s.d., veg., R. Spruce 18 (K); s.1., s.d., fr., Turpin s.n. (P); s.1., s.d., veg. s.c. (W 237252); s.1., s.d., veg. R. Spruce 19 (K); s.l., s.d., veg., M. Mélinon s.n. (P); s.1., 06/1856, veg., s.c. (P).

Distribuição e ecologia: Mezilaurus itauba apresenta a segunda mais ampla distribuição geográfica do gênero, alcançando desde a Bolívia, Peru, Equador, Colômbia, Venezuela, Suriname e Guianas, até o centro-oeste do Brasil (Figura 19). A espécie ocorre na sub-região Amazônica, províncias de Napo, Imerí, Guyana Úmida, Roraima, Amapá, Varzea, Ucayali, Madeira, Tapajós-Xingú, Pará, Pantanal e Yungas (Figura 1). Mezilaurus itauba é uma espécie característica da Bacia Amazônica, ocorrendo na floresta de terra firme, mata de várzea, floresta devastada (capoeira aberta), mata de carrasco, matas ciliares e florestas secundárias. A espécie ocorre desde o nível do mar, geralmente abaixo de 500 m na Amazônia central, podendo alcançar até 800 m na Serra dos Carajás, leste do estado do Pará e no Distrito de Palcazu no Peru. Na província de Zamora-Chinchipe no Equador ocorre entre 1100-1400 metros de altitude.

Fenologia: Flores coletadas de janeiro a dezembro, frutos em janeiro e de março a dezembro.

Etimologia: O epíteto itauba é baseado em um dos nomes populares mais conhecidos do gênero, "itaúba”, que significa madeira de pedra.

Status de conservação: Mezilaurus itauba foi categorizada como "Vulnerável" (VU) pela IUCN (IUCN 2001), contudo, possui distribuição geográfica ampla e grande quantidade de espécimes coletados recentemente. Por essa razão, nós sugerimos para a espécie a categoria "Menor Preocupação" (LC) (2001).

Nome popular: itaúba, ita-uba, itaúba-abacate, itaúba-amarela, itaúba-amarela-comum, itaúbavermelha, itaúba-preta, itaúba-basina, itaúba-xumbo, itaúba-pixuna, itaúba-roxa, itaúba-surubim, itaúba-penimá, itaúba-peuma, itaúba-da-campina, itaúba-folha-miúda, itaúba-da-folha-miúda, itaúba-grande, itaúba-piúna, itaúba-verdadeira, itaubarana-pixacatinga, louro-abacate, louro- 
itaúba, cedro-pardo, cedro-preto (Brasil), Parature (Kurripaco), Japiu-dlr (Puinava), Ita-iba (geral) (Colômbia). Taoub-jaune, taoub-brun (Guiana Francesa), kaneelhout (Suriname), kaneeripisi (Guiana Inglesa), itaúba-amarilla, itaúba-colorada (Bolívia), paraturi, parature-negro (Venezuela), ita-uba (Tupi-guarani), lorê (povo indígina Nhambiquara do Mato Grosso e Rondônia, Brasil), quariquara-amarela (Rondônia, Brasil), chancaca, chancaca-amarilla, paltamoena (Peru). Segundo Kostermans (1938c) Apisi-ie (Sar.), siruaballi tataroo, ajomonto horadihoro, ajomonto diamaro, kjarie kjanarie, kaneerju. (Car).

Importância econômica: Devido a sua alta durabilidade e resistência, a madeira de Mezilaurus itauba é a preferida para construção de estrutura de embarcações na Amazônia (Huber 1909; Kostermans 1938c; Record \& Hess 1942; Medina 1966; Lisboa et al. 1991; Vicentini et al. 1999). Spruce em 1850 relatou "a espécie possui a mais valiosa madeira para construção que a Amazônia fornece" (Hooker 1851). Sua madeira é indicada também para construções externas como pontes, postes, moirões, estacas, esteiros, cruzetas, dormentes; na construção civil para vigas, caibros, ripas, tacos, tábuas, esquadrias, lambris, forro, fabricação de móveis; na confecção de cabos de ferramentas, implementos, embalagens, carroçarias, vagões de trens, tanoaria, barris e tonéis; obras portuárias, como estacas marítimas, trapiches (Hooker 1851; Hoehne \& Kuhlmann 1951; Rizzini 1978; Lisboa et al. 1991; MacGrath et al. 2005). De acordo com Spruce a polpa do fruto de $M$. itauba é comestível, embora um pouco resinosa, lembrando espécies de Myrtaceae comum em campos, e um vinho é feito de seus frutos, da mesma forma que da palmeira do açaí (Hooker 1951; Kostermans 1938c; Medina 1966; Rizzini 1978). A espécie também é utilizada na arborização urbana (Record \& Hess 1942) e seus frutos são apreciados pela avifauna (Lorenzi 2002).

Mezilaurus itauba é uma típica espécie do gênero e sua área de distribuição geográfica é ampla, refletindo sua grande variação morfológica. A espécie pode ser caracterizada pela 
combinação das seguintes características: râmulos pubescentes a pubérulos próximos ao ápice, lâminas foliares glabras a subglabras, inflorescências do tipo duplo racemo (dibótrio) com ramos laterais umbeliformes, uma bractéola na base dos pedicelos, receptáculo internamente pubescentes, tépalas menores que o receptáculo, representando $1 / 3^{1}-1 / 4(-1 / 5)$ do comprimento da flor, filetes pubescentes, pistilo glabro e cúpulas com diâmetros do mesmo tamanho ou menores que os pedicelos na frutificação.

A espécie é bastante semelhante à Mezilaurus caatingae, contudo, esta última apresenta ramos glabros, lâminas foliares com nervuras imersas em ambas as faces, pecíolo glabro e três bractéolas na base de cada pedicelo. Mezilaurus itauba pode ser confundida também com Mezilaurus decurrens, no entanto, esta última apresenta lâminas foliares estreito-elípticas ou lanceoladas, estames conados e pistilo pubescente no ovário.

Mezilaurus itauba compartilha caracteres muito semelhantes à M. glabriantha. Porém, esta última espécie apresenta ramos laterais da inflorescência glabros, receptáculo, filetes e cúpulas internamente glabras. Mezilaurus itauba apresenta distribuição amazônica, ao passo que M. glabriantha é endêmica da Floresta Atlântica do estado do Espírito Santo.

Mezilaurus itauba apresenta semelhanças morfológicas também com $M$. introrsa. Mezilaurus introrsa apresenta, no entanto, flores globosas e glabras, pedicelos pubérulos, tépalas do mesmo tamanho ou ligeiramente maiores que o receptáculo, ca. $1 / 2$ do comprimento da flor e anteras introrsas.

Na Amazônia central, M. itauba é bastante confundida com M. synandra. Todavia, $M$. synandra apresenta inflorescências mais curtas, 1,4-7,5 cm compr., flores globosas, tépalas do mesmo tamanho do receptáculo, cerca de $1 / 2$ do comprimento da flor, estames conados, ovário piloso e frutos pubescentes no ápice. Mezilaurus itauba apresenta inflorescências geralmente mais longas, 3-11 cm, flores globosas ou elipsoides, tépalas menores que o receptáculo, cerca de $1 / 3^{-1 / 4}(-1 / 5)$ do comprimento da flor, estames livres, ovário glabro e frutos glabros no ápice. 
Béguin et al. (1985), citaram M. synandra para Loreto no Peru e entre elas, as coletas de Bernardi 16227 e árvore 7/58. Na figura sete do trabalho os autores apresentam o desenho do pistilo da espécie como glabro, não se tratando, portanto, de $M$. synandra. Tais coletas foram analisadas no presente trabalho (herbários G e MBM), e constatadas como M. itauba.

Com mais de 215 coleções da espécie avaliadas, foram sinonimizados aqui quatro binômios em Mezilaurus itauba: M. micrantha, M. palcazuensis, M. campaucola e M. opaca.

Segundo van der Werff (1987), M. micrantha diverge de M. itauba por apresentar flores menores, ápice da folha obtuso, mas nunca arredondados, ausência de pontos glandulares na folha, margem ligeiramente revoluta e folhas escurecidas quando desidratadas. $\mathrm{O}$ autor descreveu as flores de $M$. micrantha contendo 1-1,1 $\mathrm{mm}$ de comprimento, contudo, foi verificado em seu isótipo (Rodrigues \& Coelho 7555), depositado no herbário INPA, flores variando de 1,5-1,75 mm compr. Por outro lado, para M. itauba, van der Werff (1987) referiu as flores com tamanho de 1,5-2 mm compr. Em adição, foram encontradas em inúmeras coletas, assim como Kuhlmann 1925 e Mantovani \& Rocha 12746, variação no comprimento das flores de 1,1-2 mm compr. Com relação ao ápice da lâmina foliar, no isótipo de M. micrantha, Rodrigues \& Coelho 7555, foi encontrado variando de agudo a acuminado, enquanto no lectótipo de M. itauba (Spruce 643), ocorre de agudo a obtuso. Em inúmeras outras coletas, assim como Ducke s.n Spruce 965 e B. W. 3829, o ápice da lâmina foliar pode variar de agudo a arredondado.

Apesar de terem sido citados como ausentes por van der Werff (1987), no isótipo de $M$. micrantha (Rodrigues \& Coelho 7555), depositado no herbário INPA, foram observados pontos glandulares nas lâminas foliares. Por outro lado, folhas escurecidas e margem ligeiramente revoluta podem ocorrer ou estar ausentes em Black 47-930, Froés 28898, Santos et al. 743, Krukoff 5221. Portanto, Mezilaurus micrantha possui todas as suas características incluídas dentro da variação morfológica de $M$. itauba, por essa razão, nós realizamos a sinonimização. 
Van der Werff (1987), ao descrever Mezilaurus palcazuensis, relatou que a coleta Hartshorn et al. 2691 se tratava de uma nova espécie pelas folhas com ápice agudo e flores sésseis. No entanto, no holótipo de Mezilaurus palcazuensis (Hartshorn et al. 2691) ocorrem flores com pedicelo de 0,5 $\mathrm{mm}$ compr. e lâmina filiar com ápice também obtuso. Foram analisadas outras coleções da mesma região da coleta do espécime tipo de Mezilaurus palcazuensis (Hartshorn et al. 2691), G. Hartshorn \& J. Quijano 2945 e G. Hartshorn \& J. Quijano 2975. Tais coletas apresentam pedicelos variando de $0,5-1,5 \mathrm{~mm}$ e ápice das lâminas foliares de agudo a acuminado. Em adição, coletas oriundas da Guiana Francesa, Melinon 619, Mélinon 46 e Mélinon s.n., apresentam também, pedicelos 0,5-1,5 mm e ápice da lâmina foliar de aguda a obtusa. Por essa razão, no presente trabalho foi sinonimizado Mezilaurus palcazuensis em M. itauba.

Van der Werff (1987), ao descrever M. opaca, demonstrou na chave de identificação do seu trabalho que $M$. opaca possuía tépalas encurvadas, receptáculo constricto no ápice e flores depresso-globosas. Segundo o autor, tais características estariam ausentes em M. itauba. Em inúmeras coletas, assim como Jardim 587, Aluisio s.n. e Sperling et al. 5614, podem-se encontrar flores com ampla variação, com tépalas de eretas a encurvadas e receptáculo constricto no ápice ou não. Por outro lado, no holótipo e isótipos de M. opaca (Revilla 1226) pode-se verificar flores globosas, característica amplamente encontrada em M. itauba. Gentry et al. 41945 é uma coleta oriunda da mesma região do espécime-tipo de Mezilaurus palcazuensis, porém, apresenta todas as características vegetativas e reprodutivas do material-tipo de M. opaca (Revilla 1226). Portanto, não há nenhuma característica que corrobore a separação de $M$. opaca como uma espécie à parte de M. itauba.

Mezilaurus campaucola, segundo van der Werff (2003), deveria estrar na chave de identificação de van der Werff (1987) juntamente com M. navalium, uma espécie da Floresta Atlântica do sudeste do Brasil. Seguindo a chave de identificação de van der Werff (1987), $M$. 
campaucola apresentaria flores glabras, ao passo que em $M$. itauba, estas seriam pubescentes. Após análise de cerca de 215 coleções de $M$. itauba, pode-se verificar que suas flores podem variar de pubescentes a glabras. Em inúmeras coletas foi constatado flores variando de glabras a pubérulas na mesma coleta, tais como Coelho 1873 (Brasil), Jardim 587 (Bolívia) ou Valencia et al. 67359 (Equador). Todas as outras características de M. campaucola se encaixam na variação de $M$. itauba. Por essa razão, a circunscrição de $M$. itauba aqui, inclui flores pubescentes, pubérulas a subglabras a glabras.

Ao descrever Acrodiclidium anacardioides, Acrodiclidium itauba var. amarella e Oreodaphne hookeriana, Meissner (1864) citou como síntipos Spruce 2961, Spruce 646 (numeração correta Spruce 965) e Spruce 669 respectivamente. O autor não designou holótipo, tão pouco citou em qual coleção estariam alojados os materiais-tipo. Por essa razão, os espécimes Spruce 2961, Spruce 646 (numeração correta Spruce 965) e Spruce 669, depositados no herbário $\mathrm{K}$, foram escolhidos no presente trabalho como lectótipos. Os exemplares referidos são representativos do que foi descrito nos prótologos e apresentam bom estado de conservação.

Mez (1905), ao descrever Silvia polyantha, indicou o síntipo, Ule 6055, depositado no herbário de Berlim (B). Porém, em março de 1943, após bombardeios aéreos à cidade de Berlim, durante a Segunda Guerra Mundial, esse espécime foi destruído, juntamente com cerca de quatro milhões de exsicatas (Vogt, comunicação pessoal). Van der Werff (1987) escolheu (inferencialmente) um lectótipo para Silvia polyantha, contudo, tal espécime já havia sido destruído. Sendo assim, um novo lectótipo é aqui escolhido para o herbário do Royal Botanic Garden (K).

No protólogo de Silvia rondonii, Mez (1924) citou como material original "In Brasillia, Civit. Mato Grosso, ad Três Buritys (Comissão Rondon, leg. Kuhlmann nr. 1976 K. - Comm. cl. Hoehne). Expeditionis directori, generali Rondon, dicata species". Van der Werff (1987) interpretou essas informações referindo esta coleta como depositada no herbário K, porém o autor 
relatou não ter visto o exemplar. Provavelmente, a letra K, citada no protólogo é uma referência ao nome do autor da coleta, Kuhlmann, e não ao herbário do Royal Botanic Gardens (K). Nenhum espécime de Kuhlmann 1976 foi encontrado nos herbários visitados na Europa, tão pouco no herbário K. Em adição, Kostermans (1938c) não mencionou nenhum exemplar de Kuhlmann 1976 para os herbários europeus, apesar de ter visitado inúmeros deles para revisar Mezilaurus. Por outro lado, muitas coletas e espécimes-tipo, usados por Mez, foram destruídos nos herbários da Alemanha durante a Segunda Guerra Mundial (Stafleu \& Cowan 1981). Por essa razão, nós escolhemos aqui um lectótipo para Silvia rondonii, depositado no herbário SP.

Ao descrever Acrodiclidium anacardioides, Meissner (1864) citou no protólogo o síntipo como "In Brasillia bor. prope S. Carlos del Rio Negro (Spruce n. 2961!). Todavia, foi verificado em diferentes herbários conflito na localidade e data desta coleta. Após a análise das cadernetas de campo de Richard Spruce na biblioteca do Royal Botanic Garden (Kew) em Londres, foi constatado que o tipo de Acrodiclidium anacardioides foi coletado na seguinte localidade: "Venezuela, San Carlos del Rio Negro, Abril 1853 (Spruce 2961)". O próprio autor escreveu na primeira página da caderneta como lembrete “A partir do número 2952 é além das fronteiras Venezuelanas". As informações são claras também nas páginas que antecedem a descrição da coleta. Portanto, nós desconsideramos o que foi citado no protólogo por Meissner (1864) e Bentham (1878) como Spruce 2961 coletado no Brasil e reconsideramos a localidade da coleta como Venezuela.

As coletas Spruce 643 (julho) e Spruce 646 (abril) apresentaram conflitos de datas e numeração. Após analisar as cadernetas de campo do autor das coletas, Richard Spruce, foi constatado que Spruce 646, citada no protólogo por Meissner (1864) como material original de Acrodiclidium itauba var. amarella, correspondia a uma coleta de Isolepis (Oncostylis) (Cyperaceae). Contudo, posteriormente a publicação de Meissner (1864), Richard Spruce escreveu em sua caderneta na coleta Spruce 965 "para 965 Meissner tem 646" e intitulou a coleta 
como "Acrodiclidium itauba amarela". Por essa razão, nós corrigimos o lectótipo de Acrodiclidium itauba var. amarella para Spruce 965.

A coleta Spruce 643, citada no protólogo por Meissner (1864) como espécime-tipo de Acrodiclidium itauba, correspondia na caderneta de campo de Richard Spruce a uma coleta de Paspalum (Poaceae). No entanto, na coleta 818, Richard Spruce escreveu "Acrodiclidium itauba Meissner". Por essa razão, nós corrigimos o lectótipo de Acrodiclidium itauba como sendo Spruce 818 .

Um isótipo de Acrodiclidium itauba, Spruce 818 (como 643) e de A. itauba var amarella, Spruce 965 (como 646) foram também destruídos no herbário do Museu de História Natural de Viena, Áustria (W) durante a Segunda Guerra Mundial. 


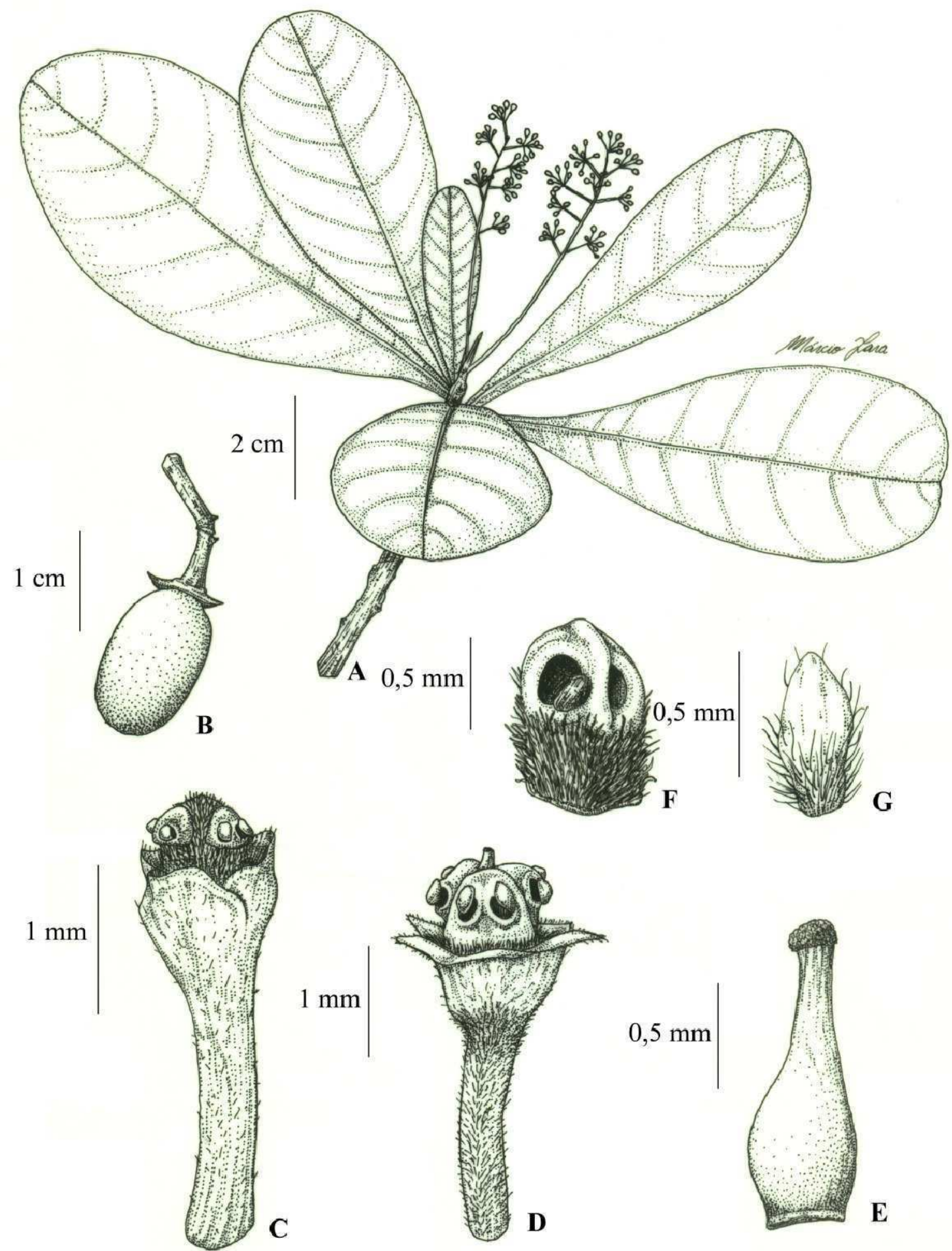

Figura 18: Ilustração de Mezilaurus itauba. A: ramo com flores (Sperling et al. 5614); B: fruto (Ramos 1876); C-D: flores; E: pistilo; F: estame (Sperling et al. 5614); G: estaminódio representante da série IV do androceu (Silva \& Bahia 2909). 


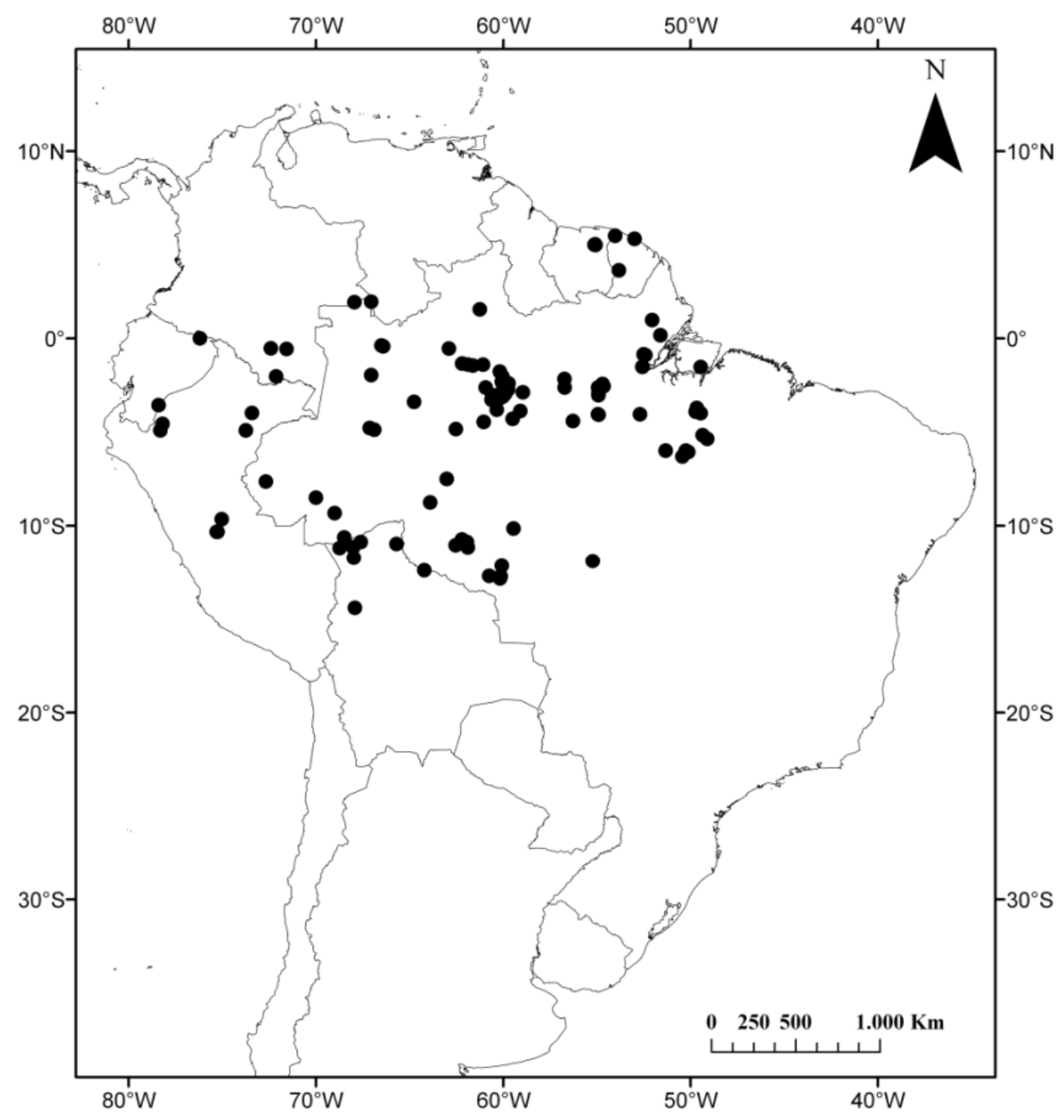

Figura 19: Mapa de distribuição geográfica de Mezilaurus itauba (pontos). 
1.8. Mezilaurus microphylla F. M. Alves \& V. C. Souza, sp. nov. ${ }^{2}$ Tipo: Brasil. Tocantins, Miracema do Tocantins, Fazenda Lontra, acesso ao córrego Santa Luzia, 13/01/1999, Árbocz 6491 (holótipo, UB; isótipo, HTO).

(Figura 20).

A Mezilauro crassiramea foliis strictis ellipticis vel oblanceolatis saepe falcatis, glabris, inflorescentia racemosa, ramis eius lateralibus umbelliformibus, glabris, floribus glabris differt

Arbusto ca. 1,8 m alt. Ritidoma desconhecido. Râmulos 1,5-2 mm diâm., cilíndricos, marrom a marrom-esverdeados, pubérulos somente próximo ao ápice, com lenticelas conspícuas próximas do ápice; catafilos ovados a lanceolados, 4,5-5 mm compr., amarelos, seríceos. Folhas alternas, 4,9-9,6 × 1,8-3 cm. Lâminas estreito-elípticas a oblanceoladas, 2-3 vezes mais longas que largas, faces abaxial e adaxial glabras, base aguda a ligeiramente atenuada, simétrica, ápice agudo a acuminado, margem plana, pontuações glandulares na face abaxial, muitas vezes inconspícuas. Venação ligeiramente broquidódroma, 9-12 nervuras por lado, ligeiramente proeminente nas faces abaxial e adaxial; nervuras secundárias formando um ângulo de 50-85 com a primária, juntando com as suprajacentes em ângulos agudos a retos; terciárias reticuladas ou percorrentes, oblíquas. Pecíolo $3-9 \times 1-1,25 \mathrm{~mm}$, representando $7-12 \%$ da folha, ligeiramente canaliculado, glabro a subglabro, base ligeiramente dilatada. Inflorescências do tipo duplo racemo (dibótrio) com ramos laterais umbeliformes, axilares ou próximas do ápice dos ramos, 2,5-8,2 cm compr., do mesmo tamanho a ligeiramente menores que as folhas, glabras a subglabras; ramos laterais 0,5-2,5 cm compr., 2-5 flores por ramo lateral; pedúnculos 2,8-4,2 cm compr. Bractéolas na base dos ramos laterais, $0,75-1 \times 0,3-0,5 \mathrm{~mm}$, uma bractéolas na base dos pedicelos, $0,5-0,8 \times$ 0,3-0,4 mm, triangulares, glabras, decíduas. Pedicelo 3-4 mm compr., glabros. Flores 1,8-2 mm diâm., 1,6-1,7 mm compr., verdes, depressas, externamente glabras. Tépalas iguais a subiguais, quando subiguais externas ligeiramente menores, externas $0,6-0,8 \times 0,9-1 \mathrm{~mm}$, internas $1-1,1 \times$ 1-1,25 mm, ovadas, ápice obtuso, margem ligeiramente papilosa, internamente pubescentes a

${ }^{2}$ Espécie aceita para publicação: Brittonia 
pubérulas, do mesmo tamanho do receptáculo, $1 / 2$ do comprimento da flor. Estames livres, 1,25$1,5 \times 1,25-1,5 \mathrm{~mm}$, inclusos na antese; anteras $0,4-0,5 \times 0,6-0,75 \mathrm{~mm}$, extrorsas, triangulares, glabras frontalmente, pubescentes na face dorsal, papilosas no ápice; filetes $0,6-0,75 \times 1-1,25$ $\mathrm{mm}$, quadráticos ou retangulares, ligeiramente maiores que as anteras, pubescentes. Estaminódios ausentes. Pistilo 1,4-1,6 mm compr., glabro; ovário 0,9-1 mm compr., globoso; estilete 0,4-0,5 mm compr., exserto na antese. Receptáculo 0,5-0,75 mm compr., glabro internamente. Fruto desconhecido.

Distribuição e ecologia: Mezilaurus microphylla apresenta distribuição restrita ao Brasil, conhecida somente para a região norte do país, estado do Tocantins (Figura 21). A espécie está representada na sub-região Chaquenha, província do Cerrado (Figura 1) e foi coletada há $220 \mathrm{~m}$ de altitude.

Fenologia: Coletada com flores em janeiro.

Etimologia: O epíteto microphylla é baseado nas folhas da espécie, que em média são pequenas dentro do gênero.

Status de Conservação: Mezilaurus microphylla possui restrita distribuição, conhecida por uma localidade e um espécime do estado do Tocantins. Portanto, não há informação precisa a respeito do seu risco de extinção, baseado na distribuição ou status da população. Por essa razão, a espécie deve ser considerada como "Dados Deficientes" (DD) ( IUCN 2001).

Importância econômica: desconhecida.

Mezilaurus microphylla é caracterizada por apresentar folhas 4,9-9,6 × 1,8-3 cm, lâminas foliares estreito-elípticas a oblanceoladas, glabras, pecíolo 7-12\% da folha, inflorescências do tipo duplo racemo (dibótrio) com ramos laterais umbeliformes, glabras, flores depressas, glabras, tépalas do mesmo tamanho do receptáculo, $1 / 2$ do comprimento da flor. 
Assim como M. microphylla, no Brasil central ocorre também M. crassiramea, porém, esta última espécie possui râmulos lanosos no ápice, tornando vilosos e pubescentes, lâminas foliares elípticas, largo-elípticas a obovadas, face abaxial hirsutas, vilosas a lanosas, inflorescências do tipo duplo racemo (dibótrio) com ramos laterais não umbeliformes, pubescentes e flores com tépalas menores que o receptáculo, $1 / 3^{1}-1 / 5$ do comprimento da flor.

Mezilaurus microphylla pode ser confundida com M. vanderwerffii, contudo, a última espécie apresenta lâminas foliares elípticas a obovadas, pecíolo $2-5 \%$ da folha, receptáculo pubescente internamente, além de ocorrer somente no Mato Grosso e Mato Grosso do Sul.

Apesar de M. microphylla ser conhecida somente pelo holótipo e o isótipo e a coleta não apresentar fruto, as características citadas acima conferem conspícuos atributos que a diferem das demais espécies do gênero e suficientes para descrevê-la como uma nova espécie. 


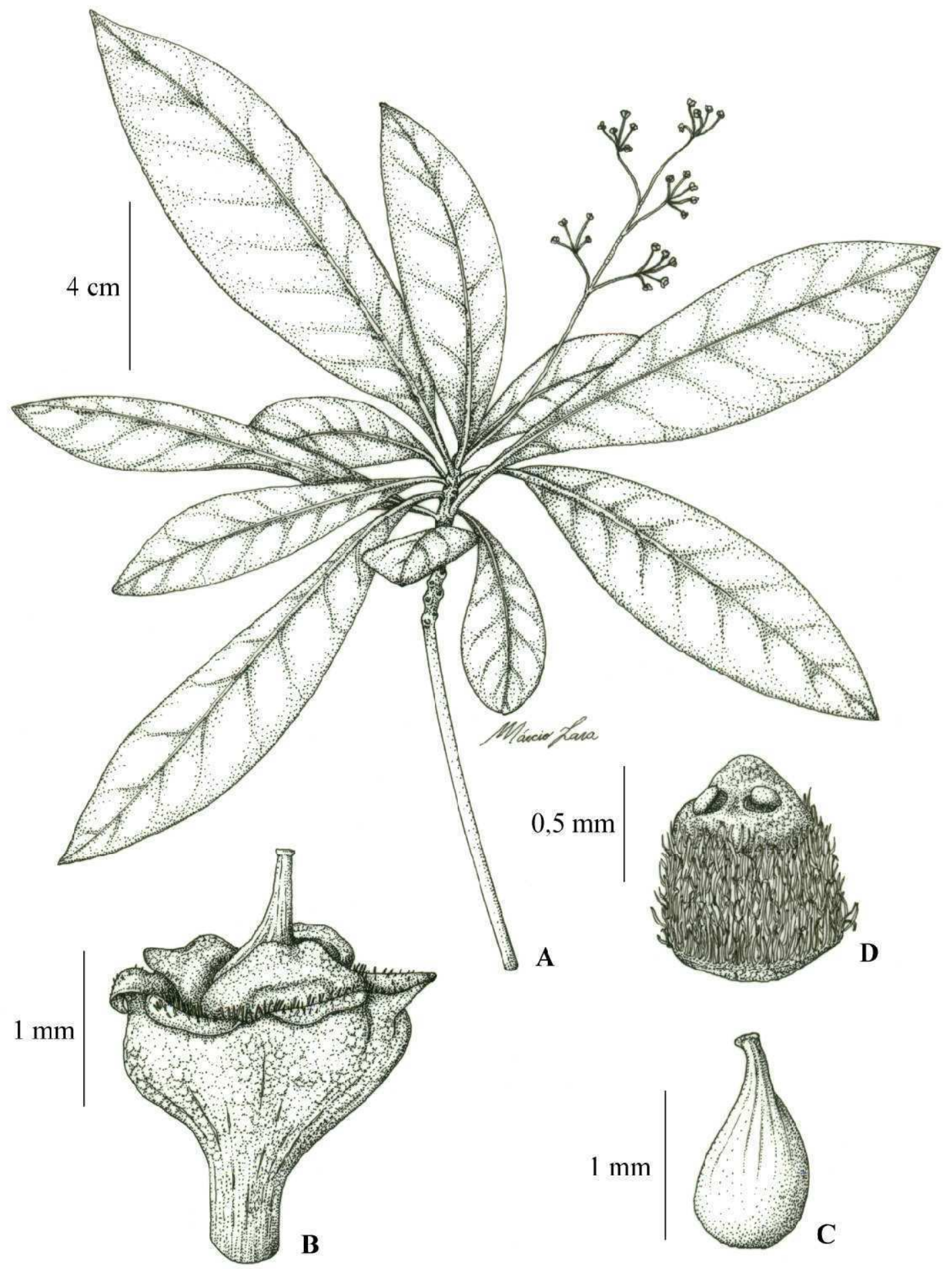

Figura 20: Ilustração de Mezilaurus microphylla. A: ramo com flores; B: flor; C: pistilo; D: estame (holótipo). 


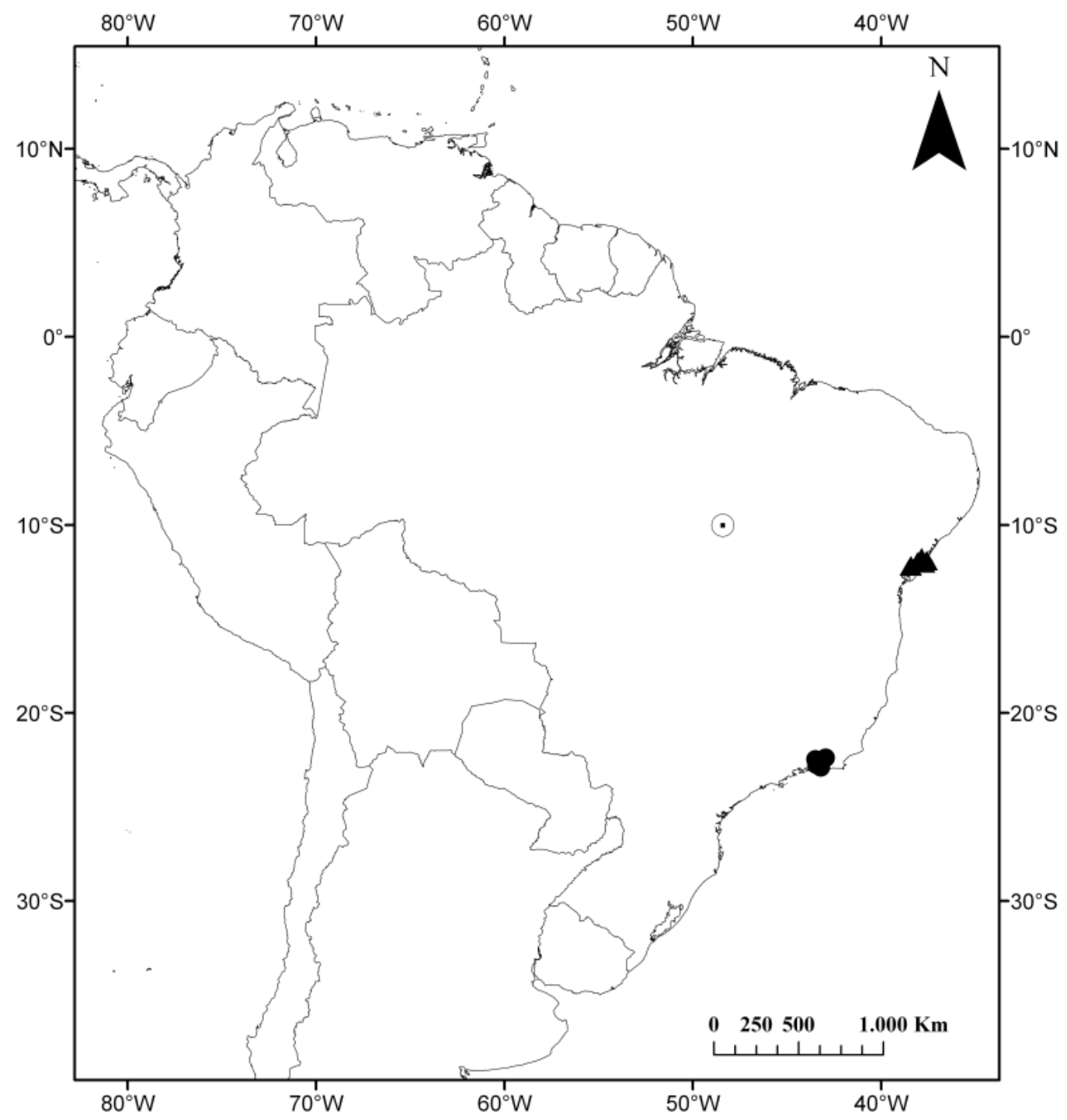

Figura 21: Mapa de distribuição geográfica de M. microphylla (círculo com ponto central), M. navalium (pontos) e M. revolutifolia (triângulos). 
1.9. Mezilaurus navalium (Allemão) Taub. ex Mez, Arbeiten Königl. Bot. Gart. Breslau 1: 112. 1892. Silvia navalium Allemão, Opúscula ("Plantas Novas do Brasil”). 1848. Silvaea navalium (Allemão) Meisn. in DC., Prodr. 15 (1): 84. 1864. Endiandra navalium (Allemão) Benth. in Benth. \& Hook. f., Gen. Pl. 3 (1): 154. 1880. Mezia navalium (Allemão) Kuntze, Revis. Gen. Pl. 2: 574. 1891. Tipo: Brasil. Rio de Janeiro, s.d., Allemão s.n. (lectótipo, escolhido por Kostermans (1938c), R [destruído]; lectótipo, designado aqui, G-DC; isolectótipos, BM, NY). (Figura 22).

Árvores até $30 \mathrm{~m}$ alt. Ritidoma desconhecido. Râmulos 1,5-6 mm diâm., cilíndricos, marrom, marrom-esverdeados a quase pretos, pubescentes a pubérulos próximo do ápice, com lenticelas conspícuas próximas do ápice; catafilos lanceolados, 3-7 mm compr., amarelos, dourados ou creme, seríceos. Folhas alternas, 3,5-23 $\times 0,8-5,1 \mathrm{~cm}$. Lâminas estreito-elípticas a oblanceoladas, 3-8,4 vezes mais longas que largas, glabras a subglabras, base aguda a decorrente, simétrica, ápice agudo a acuminado, raramente obtuso ou retuso, margem plana, pontuações glandulares na face abaxial, muitas vezes inconspícuas. Venação broquidódroma a ligeiramente broquidódroma, 12-33 nervuras por lado, impressa a proeminente na face adaxial, ligeiramente proeminente na abaxial; nervuras secundárias formando um ângulo de 60-90 com a primária, juntando com as suprajacentes em ângulos agudos a retos; terciárias reticuladas ou percorrentes, oblíquas. Pecíolo $4-23 \times 1-2,5 \mathrm{~mm}$ larg., representando $4-15 \%$ da folha, plano a ligeiramente canaliculado, pubérulo a subglabro, base dilatada. Inflorescências do tipo duplo racemo (dibótrio) com ramos laterais umbeliformes, axilares, 3-9 $\mathrm{cm}$ compr., menores que as folhas, raque principal pubérula, ramos laterais glabros a subglabros; ramos laterais $0,6-1 \mathrm{~cm}$ compr., $7-$ 11 flores por ramo lateral; pedúnculos 1,1-4,1 cm compr. Bractéolas na base dos ramos laterais $1-1,25 \times 0,5-0,75 \mathrm{~mm}$, uma bractéola na base dos pedicelos, $0,5-1 \times 0,2-0,4 \mathrm{~mm}$, triangulares, glabras a subglabras, decíduas. Pedicelo 1,5-4 mm compr., glabros. Flores 1,25-2 mm diâm., 1,3-2,5 mm compr., verdes, elipsoides, externamente glabras. Tépalas desiguais ou raramente 
iguais, quando desiguais, externas menores, externas $0,5-0,8 \times 0,5-0,8 \mathrm{~mm}$, internas $0,8-1 \times$ 0,8-1 mm, ovadas, ápice obtuso, margem papilosa, internamente pubescentes na base, menores que o receptáculo, $1 / 3^{-1} / 5$ do comprimento da flor. Estames livres, $1-1,8 \times 0,5-0,8 \mathrm{~mm}$, exsertos na antese, raro no mesmo nível das tépalas; anteras $0,5-0,8 \times 0,5-0,8 \mathrm{~mm}$, extrorsas, triangulares, glabras frontalmente, pubérulas na face dorsal, ligeiramente papilosas no ápice; filetes $0,7-1 \times$ 0,4-0,8 $\mathrm{mm}$, quadráticos ou retangulares, do mesmo tamanho a maiores que as anteras, pubescentes. Estaminódios ausentes. Pistilo 1,6-2,5 mm compr., glabro a subglabro; ovário 1-1,5 mm compr., ovoide a oblongoide; estilete 0,6-1 mm compr., exserto na antese. Receptáculo 0,91,5 mm compr., pubescente internamente. Frutos até $33 \times 22 \mathrm{~mm}$, elipsoides, glabros. Cúpulas 4-5 mm diâm., pateliformes, externamente glabras, internamente pubérulas, diâmetros maiores que os pedicelos na frutificação. Pedicelo na frutificação 2,5-3 mm compr., liso, glabro, bractéolas decíduas.

Material Examinado: BRASIL. Rio de Janeiro. Campo dos Agriões, Faz. Boa Fé, 21/07/1947, veg., H. Velloso 450 (R); Governador Portela, Monte Sinai (U), Fazenda Rocha Negra, 1935, fl., fr., G. M. Nunes 113 (RB [2 exsicatas], U [2 exsicatas]); Nova Iguaçu, Rebio Tinguá, Pedra 90, picada para o Pico do Tinguá, 12/09/2001, veg., H. C. de Lima et al. 5861 (RB [2 exsicatas]); Entorno da Rebio do Tinguá, 20/05/2006, veg, F. A. Sobrinho \& W. da Silva 26 (RB); Reserva Biológica do Tinguá, Serra do Macuco, 10/12/1996, fl., A. T. Ramalho 7 (MBM, RB); Reserva Biológica do Tinguá, 31/01/1987, fl., fr., C. A. L. de Oliveira et al. 1262 (GUA, SPSF); Reserva Biológica do Tinguá, Maciço do Macuco, 26/12/1996, fl., A. T. Ramalho \& W. Silva 1 (GUA, SPSF); Petrópolis, Alto da Imperatriz, 01/1881, fl., fr., M. Glaziou 12124 (G, K, P [01/04/1880]); 01/1881, fl., M. Glaziou 12125 (BR [2 exsicatas], G [02/02/1880], IAC, IAN, K, MG, NY, P [2 exsicatas] \{02/02/1880\}, RB, U); 02/02/1880, fl., A. Glaziou 12120 (A. Glaziou 12128?) (K, P [2 exsicatas]); Rio de Janeiro, s. d., veg., s.c., (RB 148918); Estrada de Ferro Central do Brasil, 
30/01/1933, fl., Inspectoria Florestal 113 (R, U); Serra da Estrela, estrada de rodagem RioPetrópolis, 16/07/1937, veg., J. G. Kuhlmann 136 (RB); s.1., s. d., fl., s. c. (BHCB 67571, R 30942); s.1., s. d., fl., s. c. (R 30942); s.1., s. d., fl., Herb. de J. Saldanha 5493 (R 61265); s.1., s. d., 1880, fr., M. Binot 23 (P s.n.); Teresópolis, 08/01/1879, fr., M. Glaziou s.n (K, P); 04/02/1879, veg., A. Glaziou 11470 (G, NY, P [2 exsicatas]); 05/1879, veg., A. Glaziou 11473 (BR [2 exsicatas], L, P [3 exsicatas]); 08/01/1879, fl., M. Glaziou s.n. (BM, P).

Distribuição e ecologia: Mezilaurus navalium é restrita ao Brasil, conhecida somente para o sudeste do país, sul do estado do Rio de Janeiro (Figura 21). A espécie ocorre na sub-região Paranaense, província da Floresta Atlântica Brasileira (Figura 1); característica da floresta ombrófila, de 600 a $930 \mathrm{~m}$ de altitude.

Fenologia: Coletada com flores de dezembro a fevereiro e frutos em janeiro.

Etimologia: O epíteto navalium faz referência a utilização da madeira desta espécie para construção naval.

Status de conservação: Mezilaurus navalium possui distribuição restrita ao estado do Rio de Janeiro, Brasil. A espécie foi categorizada como "Vulnerável" pela IUCN (IUCN 2001) e considerada extinta por várias décadas por não ter sido coletada por 40 anos (1947-1987). Nos últimos 20 anos, M. navalium foi recoletada por quatro vezes e apenas na Reserva Biológica do Tinguá. Por essa razão, nós sugerimos que a espécie mude de categoria, sendo considerada como “Criticamente em Perigo" (CR) (B1a+bii, B2bii) (IUCN 2001). A espécie foi considerada rara por Baitello et al. (2009) e, segundo Kasecker et al. (2009), o Parque do Tinguá, área de ocorrência da espécie, é importante para a conservação da flora brasileira.

Nome popular: tapinhoã, tapinuã, tapinhoam, tapinhoam-amarelo, tapinhoam-olho-de-sapo, canela-tapinhoã, tapinhoã-amarelo, itaúba, itaúba-amarela, itaúba-verdadeira, canela-marmelada. 
Importância econômica: A madeira de $M$. navalium foi utilizada na construção naval e civil, na fabricação de embarcações, móveis, tabuados em geral, obras de tanoeiros e todos os tipos de construções duráveis e sua casca é fonte de tanino (Allemão 1848; Record \& Hess 1942; Medina 1966). Segundo Corrêa \& Penna (1975), a madeira de Mezilaurus navalium é de lei e boa para tanoaria, substituindo o carvalho europeu. Em carta régia de 1799 , era permitido o corte de árvores da espécie sob a condição de ser vendida a artesão para ser empregada no forro das embarcações. De acordo com Cabral (2008), desde 1754, muitas dúzias de tapinhoã foram usadas para confecção dos tonéis da aguada da Marinha Real Portuguesa.

Mezilaurus navalium é caracterizada por lâminas foliares elípticas, estreito-elípticas a oblanceoladas, 3-8,4 vezes mais longas que largas, faces abaxial e adaxial glabras a subglabras, pecíolo representando $4-15 \%$ da folha, inflorescências do tipo duplo racemo (dibótrio) com ramos laterais umbeliformes, uma bracéola na base dos pedicelos, flores elipsoides, tépalas menores que o receptáculo, $1 / 3^{-1} / 5$ do comprimento da flor, filetes pubescentes, estaminódios ausentes, cúpulas com diâmetros maiores que os pedicelos na frutificação.

Além de $M$. navalium, M. glabriantha e $M$. revolutifolia são as três espécies que possuem distribuições restritas à Floresta Atlântica brasileira. Ao contrário de M. navalium, M. glabriantha apresenta lâminas foliares elípticas a obovadas, 1,7-2,8 vezes mais longas que largas, receptáculo e filetes glabros, conhecida somente para o Espírito Santo. Por outro lado, $M$. revolutifolia possui lâminas foliares elípticas a obovadas, raro estreito-elípticas, 1,6-3,2 vezes mais longas que largas, frequentemente revolutas, flores globosas, tépalas do mesmo tamanho ou maiores que o receptáculo, ca. $1 / 2$ do comprimento da flor e é restrita ao nordeste do estado da Bahia.

Mezilaurus synandra é uma espécie muito coletada na Amazônia central, também conhecida por um espécime da Floresta Atlântica do sul da Bahia. A espécie apresenta, ao 
contrário de M. navalium, lâminas elípticas, estreito-elípticas ou obovadas, 1,6-3,7 vezes mais longas que largas, flores pubérulas, globosas, tépalas do mesmo tamanho ou maiores que o receptáculo, ca. $1 / 2$ do comprimento da flor e frutos pubescentes no ápice. Já Mezilaurus crassiramea ocorre na Amazônia, Cerrado do Brasil central e Floresta Atlântica. A espécie diferencia-se de $M$. navalium por apresentar lâminas foliares elípticas, largo-elípticas ou obovadas $1,2-3,2$ vezes mais longas que largas, face abaxial hirsutas, vilosas a lanosa, adaxial hirsutas, lanosas a subglabras ou raramente glabras.

Ao descrever Silvia navalium, Allemão (1848) não citou nenhum material original, nem designou onde estariam depositados exemplares utilizados para propor a espécie. Kostermans (1938c) elegeu o exemplar Allemão s.n., depositado no herbário do Museu Nacional (R) como lectótipo (inferencial) de S. navalium. Todavia, não foi encontrada nenhuma coleta da espécie realizada por Francisco Freire Allemão no herbário do Museu Nacional (R), nem tão pouco em outro herbário brasileiro. Segundo De Candole (1880) e Stafleu \& Cowan (1976), parte do material pertencente a Francisco Freire Allemão depositado no herbário do Museu Nacional (R) fora destruído por insetos.

Francisco Freire Allemão criou o Herbário da Faculdade Nacional de Farmácia, organizado durante o período de 1833-1853, época em que lecionou Botânica na Faculdade de Medicina do Rio de Janeiro (Occhioni 1967). Segundo Occhioni (1967), este herbário foi depositado em uma antiga residência da Faculdade de Medicina do Rio de Janeiro de 1925 até 1963 e não passou por manutenção durante este período. Ao ser redescoberto, o mesmo se encontrava em péssimo estado de conservação e muitos materiais coletados por Allemão foram destruídos por insetos. Por esse motivo, é provável que inúmeros materiais originais de Mezilaurus navalium tenham sido destruídos no Herbário da Faculdade Nacional de Farmácia.

Três espécimes de M. navalium, coletados por Francisco Freire Allemão, foram localizados nos herbários G-DC, BM e NY. O espécime do herbário G-DC possui ficha escrita 
com a própria letra de Allemão: "Tapinhoan, Silvia navalium (N), Laurinea, habitat cacumina montium, Rio de Janeiro". Tais informações foram utilizadas pelo autor no protólogo. O exemplar depositado no herbário do Museu de História Natural de Londres (BM) apresenta escrito com própria letra de Francisco Freire Allemão: “Tapinhoan, Fam. Laurinea, Gen: Silvia (n), sp. navalium, Grand arbre de construction civile et navale, desta Provincia do Rio de Janeiro". O exemplar encontrado no herbário de New York Botanic Gardem (NY) representa fragmentos provavelmente do espécime do G-DC.

Segundo o conceito de "material original”, Nota 2 do Art. 9.2 do Código Internacional de Nomenclatura Botânica de Viena "Para os propósitos desse código, o material original compreende: (a) os espécimes a as ilustrações (tanto publicadas quanto não publicadas e concomitantes com o protólogo) sobre os quais pode se demonstrar que foi baseada a discrição ou diagnose que validou o nome; $(b)$ o holótipo e esses espécimes que, mesmo que não tenham sido vistos pelo autor da discrição ou diagnose que validou o nome, foram indicados como tipos (síntipos ou parátipos) do nome no ato da publicação válida; e (c) os isótipos e isossíntipos do nome independentemente se tais espécimes foram ou não vistos pelo autor que validou a discrição ou diagnose ou pelo autor do nome" (McNeill et al. 2005).

Por essa razão, mesmo não sendo citado como material original no protólogo, os exemplares Allemão s.n. depositados no BM, G e NY estão de acordo com o protólogo, com a letra de Freire Allemão e palavras usadas por ele no protólogo (Allemão 1848). Portanto, nós confirmamos que as coletas observadas no BM, G e NY são mesmo de Freire Allemão, levando em consideração grafia do autor. Consideramos também que o espécime do herbário $\mathrm{R}$ foi destruído, nós escolhemos um novo lectótipo para Mezilaurus navalium, depositado no herbário G-DC.

O protólogo de Silvia navalium Allemão foi historicamente citado como proveniente de "Plantas Novas do Brasil" (von Mohl \& Schlechtendal 1854; Stafleu \& Cowan 1976) ou 
Dissertatio (Kostermans 1938c; van der Werff 1987). Na biblioteca do Museu Nacional havia a publicação intitulada "Trabalhos da Comissão Científica de Exploração" com o protólogo de Silvia navalium entre outros trabalhos de Freire Allemão, porém, sem páginação ou data. Na biblioteca do British Museum (BM) não havia nenhuma indicação de nome do conjunto de trabalhos de Freire Allemão. Entretanto, na biblioteca do Royal Botanic Gardens (Kew) esse conjugado de artigos do autor estava com o nome lateral da incadernação como "Opuscula" e na primeira página manuscrito como "Plantas Novas do Brasil". Na biblioteca do Conservatoire et Jardin botaniques de la Ville de Genève a plublicação se apresentava em um compêndio com as separatas de Freire Allemão e outros autores, sob título de "Monographiae Phanerogamarum"..

Segundo von Mohl \& Schlechtendal (1854) "No índice recentemente comunicada da biblioteca (...) é, sob n 583, um maço de papéis do Professor botânico Francisco Freire Allemão, Rio de Janeiro (...) Tal como mencionado em uma carta anexa, o falecido proprietário, tenho-os do Professor G. Capanema, Rio de Janeiro. Ao que parece, ou de acordo com uma descrição por escrito, eles provavelmente foram destinados para a publicação sob o título "Novas Plantas do Brasil”, descritas e publicadas por Francisco Freire Allemão. No entanto, eu não sei se outras edições foram previamente publicados, é só uma conjectura. (...)"

Portanto, Freire Allemão publicou separatas (opúsculas), e as bibliotecas que receberam esses "papéis avulsos", agruparam apenas as que pessoalmente receberam em um conjunto de publicações do autor. Por essa razão, não havendo título para essa compilação. Por essa razão, utilizamos como critério para nomear essa publicação, o "Catálogos de livros, manuscritos, mapas e desenhos do British Museum" que categoriza essa separata como "Parallel Columns". Aqui nós empregamos o termo "Opúscula". 


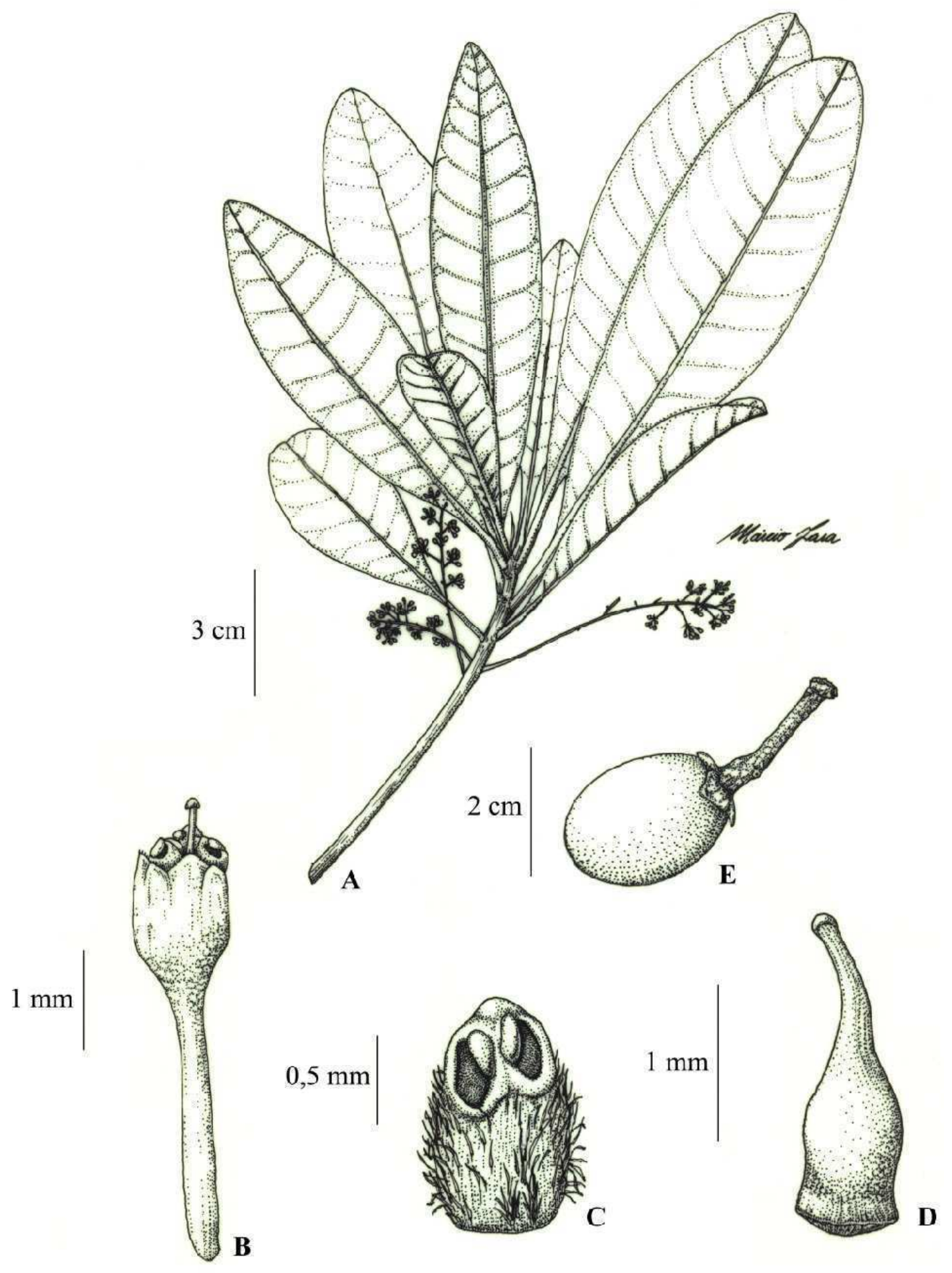

Figura 22: Ilustração de Mezilaurus navalium. A: ramo com flores; B: flor; C: estame; D: pistilo (Glaziou 12125); E: fruto (Nunes 113). 
1.10. Mezilaurus revolutifolia F. M. Alves \& P. L. R. Moraes, sp. nov. ${ }^{3}$ Tipo: Brasil. Bahia, Conde, Fazenda Bu, Mata do Fundão I, 02/02/1996, Ferreira \& Jost 885 (holótipo, RB 367573; isótipos, CEPEC, HRB, HUNEB, IBGE, IPA, MBM, RB 391883).

(Figura 23).

A Mezilaurus crassiramea foliis glabris, inflorescentiis glabris, floribus glabris ad apices ramulorum congestis differt.

Árvores até $12 \mathrm{~m}$ alt. Ritidoma estriado com sulcos rasos, cinza. Râmulos 3-5 mm diâm., angulosos, glaucos, pubérulos próximo ao ápice, com lenticelas inconspícuas próximas do ápice; catafilos lanceolados, 0,4-1 $\mathrm{mm}$ compr., creme a amarelos, pubescentes. Folhas alternas a subverticiladas, 4,3-17 × 1,6-6,7 cm. Lâminas elípticas a obovadas, raro estreito-elípticas, 1,63,2 vezes mais longas que largas, faces abaxial e adaxial glabras a subglabras, base aguda a ligeiramente cuneada, simétrica ou raro ligeiramente assimétrica, ápice agudo, obtuso ou raro retuso, margem ligeiramente revoluta ou raramente plana, pontuações glandulares na face adaxial, muitas vezes inconspícuas. Venação broquidódroma a ligeiramente broquidódroma, 10 15 nervuras por lado, nervura primária impressa na face adaxial, secundárias impressas a imersas, ligeiramente proeminente na face abaxial; nervuras secundárias formando um ângulo de $50-85^{\circ}$ com a primária, juntando com as suprajacentes em ângulos agudos a retos; terciárias reticuladas ou percorrentes, oblíquas. Peciolo 8-20 $(-30) \times 2-3 \mathrm{~mm}$, representando $7-19 \%$ da folha, plano a ligeiramente canaliculado, glabro a pubérulo, base ligeiramente dilatada. Inflorescências do tipo duplo racemo (dibótrio) com ramos laterais umbeliformes, axilares, 5-7,4 cm compr., menores que as folhas, glabras a subglabras; ramos laterais $0,9-2 \mathrm{~mm}$ compr., 2-5 flores por ramo lateral; pedúnculos 1,3-3,8 cm compr. Bractéolas na base dos ramos laterais não vistas, uma bractéola na base do pedicelo, $0,75-1 \times 0,1-0,2 \mathrm{~mm}$, lanceoladas, glabras ou pubérulas na margem do ápice, decíduas. Pedicelo 3-5,5 mm compr., glabros. Flores 1,75-2,5 mm diâm., 1,5-2 mm compr., amarelas a verdes, depressas ou globosas, externamente glabras. Tépalas iguais, $0,75-1 \times 0,75-1$

${ }^{3}$ Espécie aceita para publicação: Kew Bulletin 
mm, ovadas, ápice agudo a obtuso, margem ligeiramente papilosa, internamente glabras ou pubérulas, do mesmo tamanho ou maiores que o receptáculo, ca. $1 / 2$ do comprimento da flor. Estames livres, $1-1,2 \times 0,8-1,3 \mathrm{~mm}$, exsertos na antese; anteras $0,3-0,5 \times 0,5-1 \mathrm{~mm}$ larg., extrorsas, triangulares, glabras, ligeiramente a não papilosas no ápice; filetes $0,5-0,75 \times 0,8-1,2$ mm, quadráticos ou retangulares, do mesmo tamanho a maiores que as anteras, pubescentes. Estaminódios ausentes ou raramente 1 por flor, pertencentes a série IV do androceu, ca. 0,6-0,2 × 0,2-0,3 mm, estipitiformes, pubescentes. Pistilo 1,5-1,8 mm compr., glabro; ovário 0,75-1,2 mm compr., globoso; estilete 0,5-0,75 mm compr., exserto na antese. Receptáculo ca. 0,5 mm compr., glabro a subglabro internamente. Frutos até $28 \times 20 \mathrm{~mm}$, elipsoides a obovoides, glabros. Cúpulas 3,5-4,5 mm diâm., pateliformes, externa e internamente glabras, diâmetros iguais ou ligeiramente menores que os pedicelos na frutificação. Pedicelo na frutificação 3,5-6 mm compr., liso, glabro, bractéolas decíduas.

Parátipos: BRASIL: Bahia, Alagoinhas, Campus II, UNEB, 14/11/2003, fl., N. G. Jesus et al. 1622 (HUNEB); 14/11/2003, fr., N. G. Jesus 1868 (HUNEB); Conde, road to Sítio do Conde/Barra de Itariri, 7/01/2004, fl., T. Ribeiro et al. 329 (HRB, HUNEB); 7/01/2004, fr., N. G. Jesus et al. PS 330 (HRB, HUEFS, HUNEB, UESC); Entre Rios, Fazenda Rio do Negro, 19/03/2009, A. V. Popovkin 525, 526 (HUEFS, MO); 25/03/2009, A. V. Popovkin 527, 531 (HUEFS, MO); 03/062009, fl., fr., A. Popovkin 594 (CGMS, ESA, HUEFS, SPF); Esplanada, Fazenda Chapada, road to Sítio do Conde, 09/05/2000, fl., T. Ribeiro et al. 85 (ALCB, BAH, CEPEC, HRB, HUEFS, HUNEB, UESC).

Distribuição e ecologia: Mezilaurus revolutifolia é endêmica do nordeste do Brasil, conhecida para a porção nordeste do estado da Bahia, municípios de Alagoinhas, Conde, Entre Rios e Esplanada, sendo a única espécie exclusiva para a região (Figura 21). A espécie ocorre na sub- 
região Paranaense, norte da província da Floresta Atlântica Brasileira (Figura 1); na floresta ombrófila aberta e na mata de tabuleiro, entre 12 e $150 \mathrm{~m}$ de altitude.

Status de Conservação: Mezilaurus revolutifolia apresenta distribuição geográfica restrita ao nordeste do estado da Bahia, porém, é conhecida por nove espécimes oriundas de cinco localidades. Portanto, a espécie deve ser considerada como "Menor Preocupação" (LC), utilizando os critérios da IUCN (2001).

Fenologia: Flores coletadas de janeiro a março, maio, junho e novembro, frutos em janeiro, março, junho e novembro.

Etimologia: O epíteto revolutifolia é uma referência às lâminas foliares frequentemente revolutas da espécie.

Nome popular: louro-apagão-verdadeiro.

Importância econômica: desconhecida.

Mezilaurus revolutifolia é caracterizada por seus râmulos angulosos, glaucos, pubérulos próximos do ápice, lâminas frequentemente revolutas, glabras a subglabras, 1,6-3,2 vezes mais longas que largas, inflorescências do tipo duplo racemo (dibótrio) com ramos laterais umbeliformes, flores glabras e tépalas do mesmo tamanho ou maiores que o receptáculo, ca. $1 / 2$ do comprimento da flor.

Em Mezilaurus, até o presente, lâminas foliares fortemente revolutas são conhecidas somente em M. crassiramea. A última espécie apresenta, contudo, lâminas foliares com face abaxial hirsutas, vilosas a lanosa, inflorescências do tipo duplo racemo (dibótrio) com ramos laterais não umbeliformes, tépalas menores que o receptáculo, $1 / 3^{1}-1 / 5$ do comprimento da flor. Em adição, Mezilaurus crassiramea, apesar de também ocorrer Floresta Atlântica brasileira, a espécie apresenta registro somente para o leste de Minas Gerais e Espírito Santo, enquanto $M$. revolutifolia é endêmica do nordeste da Bahia. 
Mezilaurus revolutifolia é uma das três espécies endêmicas da Floresta Atlântica brasileira. Na região ocorre também $M$. navalium, uma espécie endêmica do estado do Rio de Janeiro, distinta por suas lâminas elípticas, estreito-elípticas a oblanceoladas, planas, $3-8(-8,4)$ vezes mais longas que largas, flores elipsoides e tépalas mais curtas que o receptáculo, $1 /{ }_{3}-1 / 5$ do tamanho da flor. Já Mezilaurus glabriantha ocorre Floresta Atlântica do estado do Espírito Santo e possui, entretanto, tépalas mais curtas que o receptáculo, $1 / 3^{1}-1 / 4$ do comprimento da flor, flores, receptáculo, estames e pistilos glabros.

Mezilaurus revolutifolia é semelhante a M. synandra, compartilhando as flores globosas, tépalas do mesmo tamanho ou maiores que o receptáculo, ca. $1 / 2$ do comprimento da flor. Mezilaurus synandra possui, ao contrário de M. revolutifolia, flores pubérulas, receptáculo pubescente internamente, estames conados, pistilo pubescente e fruto pubescente no ápice. 


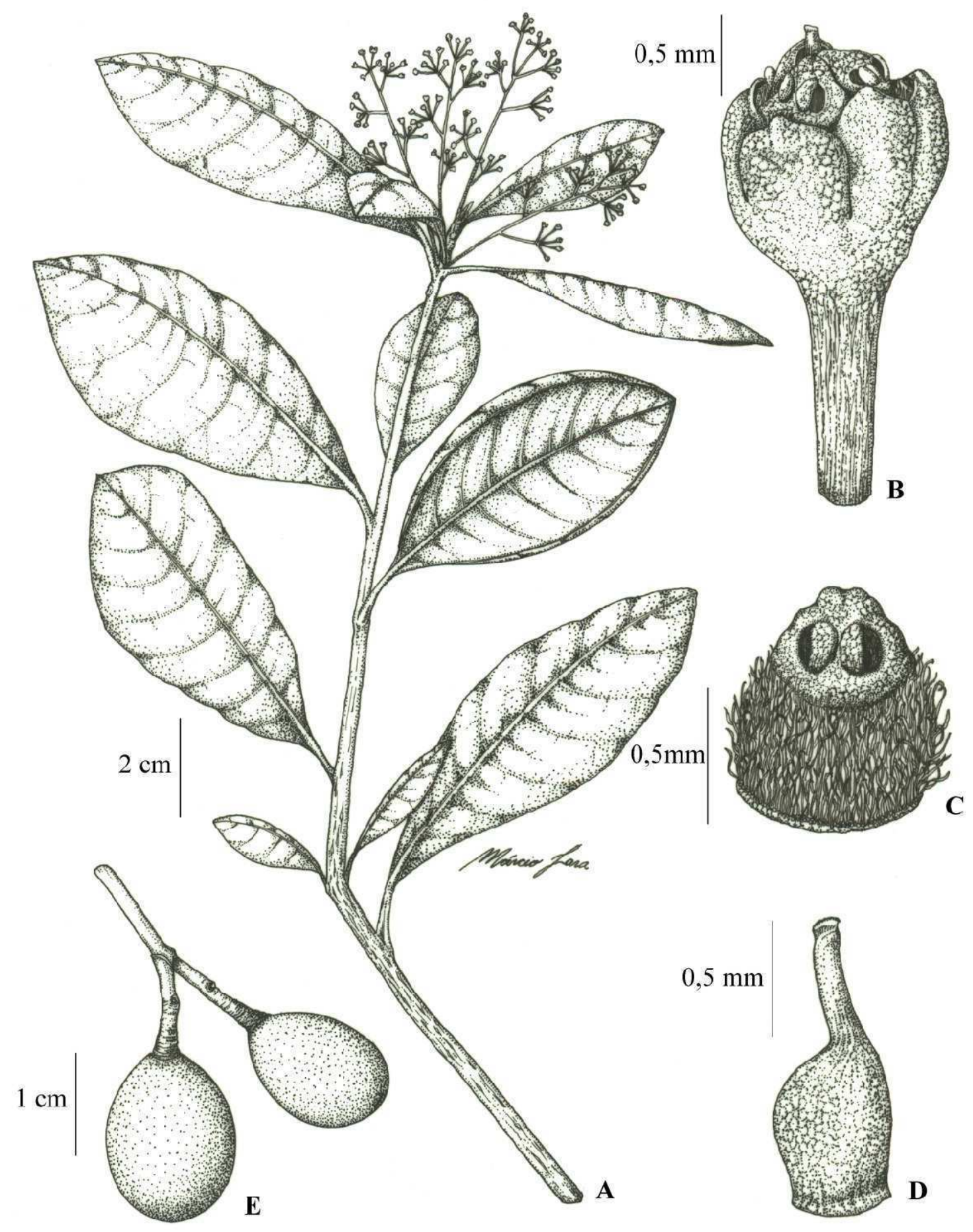

Figura 23: Ilustração de Mezilaurus revolutifolia. A: ramo com flores; B: flor; C: estame; D: pistilo (Popovkin 594); E: frutos (Jesus 1868). 
1.11. Mezilaurus sprucei (Meisn.) Taub. ex Mez, Arbeiten Königl. Bot. Gart. Breslau 1: 112. 1892. Acrodiclidium sprucei Meisn. in DC., Prodr. 15 (1): 86. 1864. Silvia sprucei (Meisn.) Mez, Jahrb. Königl. Bot. Gart. Berlin 5: 109. 1889. Mezia sprucei (Meisn.) Kuntze, Revis. Gen. Pl. 2: 574. 1891. Tipo: Brasil. Amazonas, San Gabriel da Cachoeira, Rio Negro, 05/1852, Spruce 2323 (lectótipo, escolhido por Kostermans (1938c), K [2 exsicatas]; isolectótipos, B [destruído], BM, BR, E, OXF, P [2 exsicatas]).

(Figura 24).

= Mezilaurus maguireana C. K. Allen, Mem. New York Bot. Gard. 10: 58. 1963. Tipo: Venezuela. Amazonas, Rio Guainia, Maroa, Maguire et al. 41698 (holótipo, NY; isótipos, B, OXF, U).

= Mezilaurus manausensis van der Werff, Novon 13 (3): 347. 2003. Tipo: Brasil. Amazonas, Manaus, Reserva 2206, projeto Dinâmica Biológica dos Fragmentos Florestais, árvore 1745, Mackenzie e equipe s.n. INPA/WWF 2206.1745 (holótipo, MO 5593904). sin. nov.

Árvores até $20 \mathrm{~m}$ alt. Ritidoma desconhecido. Râmulos 1,75-4,5 mm diâm., cilíndricos, marrom, marrom-avermelhados a quase pretos, pubérulo a ligeiramente tomentosos no ápice, com lenticelas conspícuas próximas do ápice, as vezes inconspícuas; catafilos lanceolados, 2-8 mm compr., amarelos ou ferrugíneos, tomentosos a seríceos. Folhas alternas a subopostas, raro opostas, 3,7-24,9 × 1,8-8,8 cm. Lâminas elípticas ou raramente estreito-elípticas, 1,8-3,4 vezes mais longas que largas, face abaxial glabra a subglabra, raro pubérula na base, adaxial glabra, base aguda, cuneada ou decorrente, simétrica ou ligeiramente assimétrica, ápice agudo a acuminado, raro obtuso, margem plana, pontuações glandulares na face abaxial, muitas vezes inconspícuas. Venação broquidódroma a ligeiramente broquidódroma, 7-24 nervuras por lado, impressa na face adaxial, proeminente na abaxial; nervuras secundárias formando um ângulo de 60-90 com a primária, juntando com as suprajacentes em ângulos agudos a obtusos; terciárias reticuladas ou percorrentes, oblíquas. Peciolo 5-35 $\times 1-3 \mathrm{~mm}$, representando $8-17 \%$ da folha, 
plano a ligeiramente canaliculado, pubérulo, subglabro ou raro ligeiramente tomentoso, base dilatada. Inflorescências do tipo duplo racemo (dibótrio) com ramos laterais umbeliformes ou raramente alguns ramos laterais mais laxos, porém, com flores sempre agrupadas a partir da metade do ramo lateral até o apice, associado a outros ramos laterais umbeliformes, axilares ou próximas ao ápice dos ramos, 3-17 cm compr., do mesmo tamanho, menores ou maiores que as folhas, pubérula ou raques principais pubérulas e ramos laterais glabros a subglabros; ramos laterais 0,6-4,8 cm compr., 5-13 flores por ramo lateral; pedúnculos 1,4-5 cm compr. Bractéolas na base dos ramos laterais $0,75-1,5 \times 0,5-0,1 \mathrm{~mm}$, uma bractéola na base dos pedicelos, $0,5-1 \times$ 0,3-0,75 mm, triangulares, deltadas ou ovadas, glabras, subglabras ou raro tomentosas ou pubérulas somente na margem do ápice, decíduas. Pedicelo pedicelo (2,5-) 5-23 mm compr., glabros. Flores 1-2 mm diâm., 1,5-2,25 mm compr., amarelas a verdes, ligeiramente elipsoides, raramente globosas, externamente glabras. Tépalas iguais ou desiguais, quando desiguais, externas menores, externas $0,25-0,6 \times 0,3-1 \mathrm{~mm}$, internas $0,5-0,8 \times 0,7-1 \mathrm{~mm}$, ovadas, ápice obtuso, margem papilosa, internamente pubérula, pubérulas ou subglabras, menores que o receptáculo, $1 / 3^{1}-{ }^{1} 5$ do comprimento da flor, raramente próximas de $1 / 2$. Estames livres, $1-1,4 \times$ 0,6-1,3 mm, exsertos na antese ou no mesmo nível das tépalas; anteras $0,4-0,8 \times 0,7-1 \mathrm{~mm}$, extrorsas, triangulares, glabras frontalmente, pubescentes na face dorsal, ligeiramente papilosas no ápice; filetes $0,5-0,9 \times 0,6-1,3 \mathrm{~mm}$, quadráticos ou retangulares, do mesmo tamanho a maiores que as anteras, pubescentes. Estaminódios ausentes. Pistilo 1,25-1,6 mm compr., glabro; ovário 0,6-0,8 mm compr., elipsoide a globoso; estilete 0,5-1 $\mathrm{mm}$ compr., exserto na antese. Receptáculo 0,6-1,25 mm compr., pubescente internamente. Frutos até $26 \times 18 \mathrm{~mm}$, elipsoides a obovoide, glabros. Cúpulas 4,5-6 mm diâm., pateliformes, externamente glabras, internamente pubescentes, diâmetros menores que os pedicelos na frutificação. Pedicelo na frutificação 7-20 mm compr., liso, glabro, bractéolas decíduas. 
Material Examinado: BRASIL: Amazonas. Manaus, Reserva 1301, s.d., fl., Projeto Dinâmica Biológica de Fragmentos Florestais - PDBFF s.n. (MO); Distrito Agropecuário da SUFRAMA, Rodovia BR 174, km 64, Fazenda Esteio, Reserva 1301 (2²3'S/5951'W), 11/09/1986, fl., M. J. R. Pereira et al. s.n. (INPA/WWF 1301.3258) (MO); Distrito Agropecuário da SUFRAMA, Rodovia BR 174, km 72, Fazenda Dimona, Reserva 2206, árvore 2118 ( $\left.2^{\circ} 19^{`} \mathrm{~S} / 60^{\circ} 05^{`} \mathrm{~W}\right)$, 07/10/1982, veg., C. A. Mackenzie et al. s.n. (MO); árvore 1745 (2¹9’'S/6005’W), 29/09/1982, fl., C. A. Mackenzie et al. s.n. (INPA/WWF 2206.1745) (MO); Rio Negro acima de Camanaus, 02/11/1971, fr., T. Prance et al. 16042 (G, L, MG, NY, INPA). PERU: Loreto. Requena, Arboreto Jenaro Herrera, 26/08/1980, fl., A. Castillo 40 (K); Pari, Jenaro Herrera, 08/12/1980, fl., R. Vásquez \& N. Jaramillo 984 (G, MO); Jenaro Herrera, arbre 1/114, 8/06/1982 fl., fr., s.c. s.n. (MO); arbre 1/262, 05/08/1982, fr., R. Spichiger \& P. A. Loizeau $4158 \quad$ (G); arbre 1/114, s.d., fl., R. Spichiger \& P. A. Loizeau 4155 (G); arbre 1/262, 08/06/1982, fl., R. Spichiger \& P.-A. Loizeau $4159(\mathrm{G})$; arbre 1/114, 07/04/1978, fl., L. Bernard s.n. (G); arbre 1/114, 09/09/1974, fl., M. Diaz 107-A (G); Arbre 1/114, 08/06/1982, fl., R. Spichiger \& P.-A. Loizeau 4156 (G); Arbre 1/114, 26/08/1980, flor, R. Spichiger \& P.-A. Loizeau 4157 (G) Arbre 1/114, 04/08/1982, fr., R. Spichiger \& P.-A. Loizeau 4154 (G). Maynas, Distrito Iquitos, Caserio, Picuruyacu, 11/02/1976, fl., J. Revilla 106 (G, MO). VENEZUELA. Amazonas: Caño Barro, por la carretera San Carlos de Rio Negro-Solano, justo al este de la Bana de Mary (1'54'40'’N/6659'49',W), 02/03/2000, veg., P. E. Berry \& G. Aymard 7503 (VEN); Estado Amazonas, Cerro Neblina base camp. on Rio Mawarinuma, 22/04/1984, fl., fr., A. Gentry \& B. Stein 46836 (G, U); Território Federal do

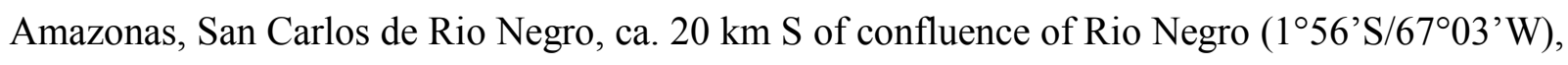
16/07/1981, fl., H. L. Clark \& P. Maquirino 8091 (INPA, MO, U, VEN); Território Federal Amazonas, Depto. Casiquiare, Rio Casiquiare, $40 \mathrm{kms}$ después de lá boca $\left(2^{\circ} 47^{\prime} \mathrm{S} / 65^{\circ} 58^{\prime} \mathrm{W}\right)$, 27/01/1991, fr., M. Collella et al. 1557 (MO); Território Federal do Amazonas, San Carlos de Rio Negro, ca. 20 km S of confluence of Rio Negro ( $\left.1^{\circ} 56^{\prime} \mathrm{S} / 67^{\circ} 03^{\prime} \mathrm{W}\right), 20 / 11 / 1980$, fl., $H$. $L$. 
Clark \& P. Maquirino 7784 (MO, VEN); 21/02/1980, fr., H. L. Clark \& P. Maquirino 7357 (VEN); San Pedro Cataniapo, San Pablo Cataniapo, middle reach of Cataniapo river (5³5’N/67²0’W), 27/08/1986, veg., S. Zent 886-19 (VEN).

Distribuição e ecologia: Mezilaurus sprucei apresenta registro de ocorrência para o Brasil, Peru e Venezuela. A espécie ocorre da Amazônia central e extremo noroeste do estado do Amazonas no Brasil, até o sul da Venezuela e nordeste do Peru (Figura 25). Mezilaurus sprucei ocorre na sub-região Amazônica, províncias de Imerí, Várzea, Guiana e Madeira (Figura 1). A espécie é comum da floresta de terra firme, de terras altas, floresta primária e inundada, em solos arenosos "ultissol" e latosssolos amarelos, de 90 a 170 m de altitude.

Fenologia: Coletada com flores em janeiro, fevereiro, abril e de junho a dezembro e frutos em janeiro, abril, junho e agosto.

Etimologia: O epíteto sprucei é uma homenagem ao botânico inglês, Richard Spruce.

Status de conservação: Mezilaurus sprucei apresenta distribuição geográfica ampla e com considerável quantidade de espécimes coletados, todavia, a espécie foi coletada somente 2 vezes nos últimos 20 anos. Portanto, é possível que Mezilaurus sprucei se encaixe a uma categoria de ameaçada de extinção em um futuro próximo. Por essa razão, esta espécie deve ser considerada como "Quase Ameaçada" (NT), utilizando os critérios da IUCN (2001).

Nome popular: itaúba (Brasil e Peru), parature, phara-ture, paratute-blanco (Venezuela).

Importância econômica: a madeira da espécie já foi utilizada na construção civil.

Mezilaurus sprucei é caracterizado por apresentar râmulos delgados, 1,75-4,5 mm diâm., pubérulos a ligeiramente tomentosos no ápice, lâminas foliares alternas a subopostas, raramente opostas, glabras a subglabras, pedicelos (2,5-) 5-23 mm compr., glabros, flores glabras, cúpulas 
com diâmetros menores que os pedicelos na frutificação, pedicelo na frutificação $7-20 \mathrm{~mm}$ compr.

A espécie pode ser confundida com $M$. itauba e as duas são simpátricas na região amazônica. Entretanto, M. itauba possui râmulos pubescentes a pubérulos próximos do ápice, folhas sempre alternas, pedicelos $0,5-6 \mathrm{~mm}$ compr., pubescentes a pubérulos ou raramente glabros, flores frequentemente pubérulas, pedicelo na frutificação 2-8 $\mathrm{mm}$ compr., cúpulas com diâmetros iguais ou ligeiramente maiores que os pedicelos na frutificação.

No presente trabalho, nós sinonimizamos Mezilaurus manausensis em M. sprucei. Os materiais-tipo de M. manausensis assim como o lectótipo de $M$. sprucei, apresentam indumento das gemas apicais com tricomas grandes e ligeiramente eretos, râmulos com poucos tricomas no ápice, somente até um centímetro do ápice das gemas, ápice de algumas lâminas foliares acuminado, nervuras secundárias na face adaxial marcadamente impresas, nervuras secundárias com ângulos chegando até próximo de $90^{\circ}$.

Segundo van der Werff (2003), Mezilaurus manausensis diferencia-se de M. sprucei por ocorrer nesta última espécie longos pedicelos. Porém, foi verificado sobreposição dos valores de comprimento dos pecíolos nos materiais originais de Mezilaurus manausensis e M. sprucei. Os parátipos de Mezilaurus manausensis (Projeto Dinâmica Biológica de Fragmentos FlorestaisPDBFF- 3587 e 3258) e seu isótipo (Mackenzie et al.-INPA/WWF 2206.1745) (MO), apresentam pedicelos 3-9 mm compr. Por outro lado, no lectótipo de $M$. sprucei os pedicelos podem ocorrer de 6-23 mm compr. Outros espécimes, como Clark \& Maquirino 7784 e Clark \& Maquirino 8091, apresentam tamanhos intermediários, variando de 2,5-12 mm compr. 


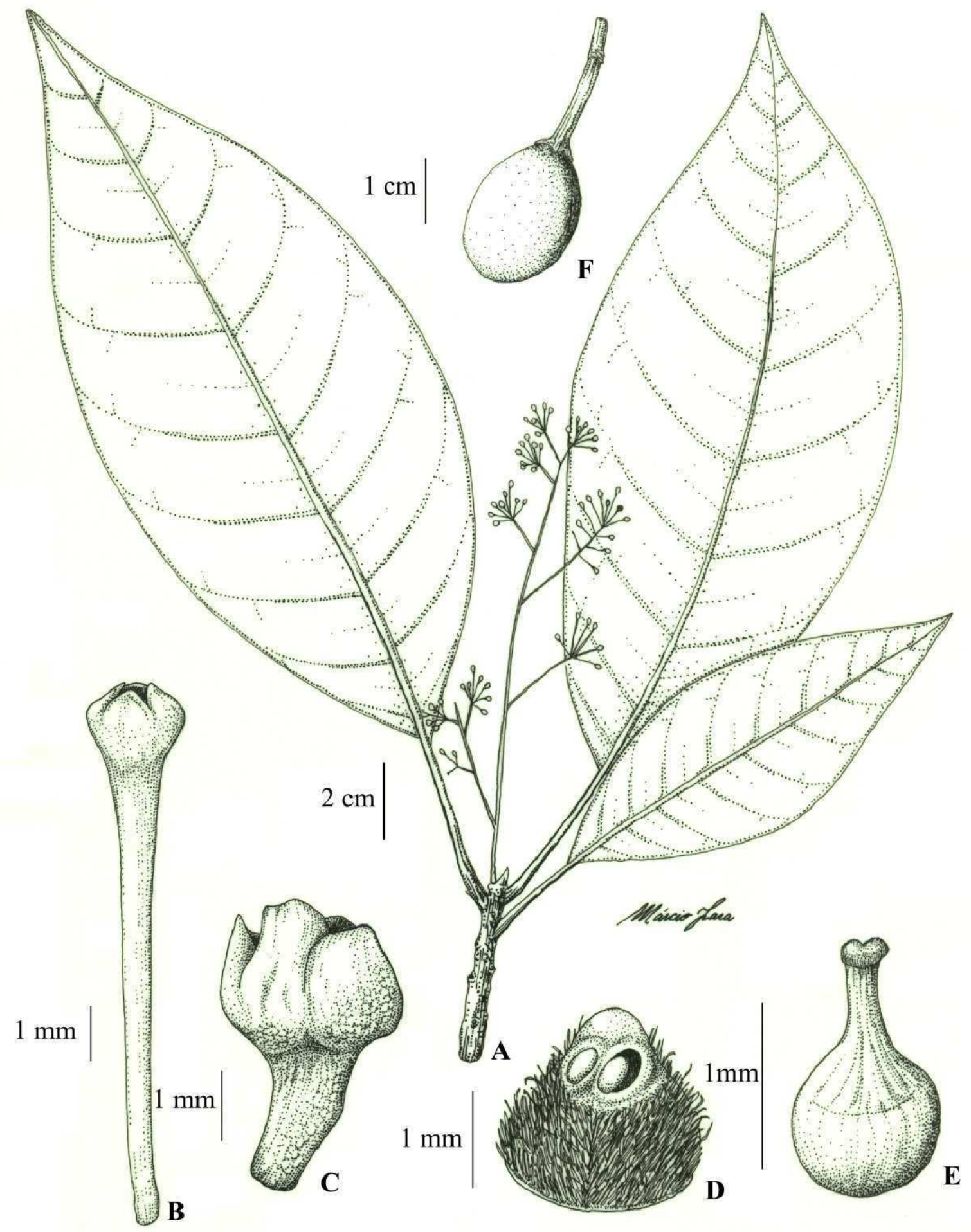

Figura 24: Ilustração de Mezilaurus sprucei. A: ramo com flores; B: flor com longo pedicelo (lectótipo). C: flor com pedicelo curto (Maguire et al. 41698); D: estame; E: pistilo (Clark \& Maquirino 7784); F: fruto (Prance et al. 16042). 


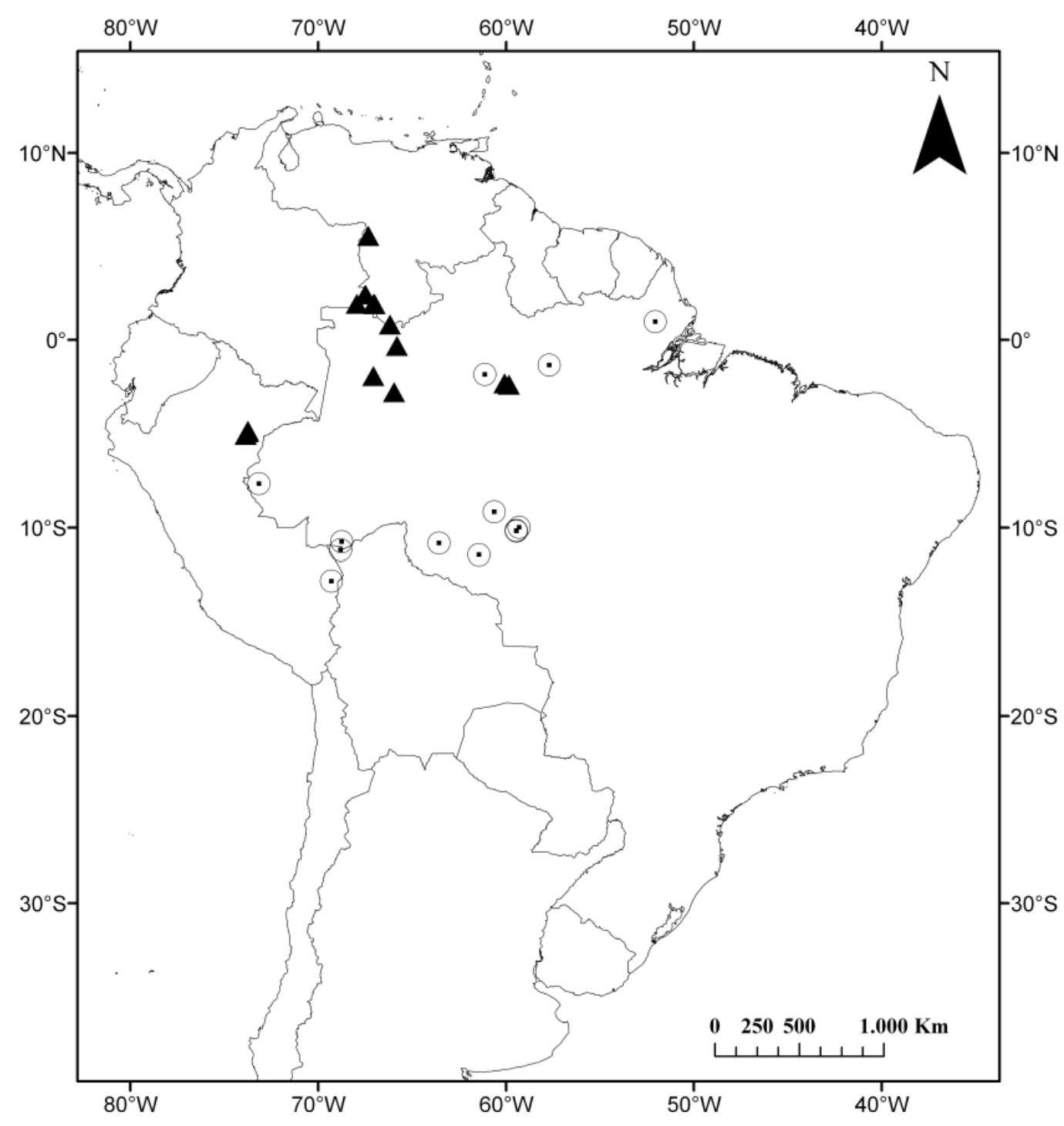

Figura 25: Mapa de distribuição geográfica de Mezilaurus sprucei (triângulos) e $M$. subcordata (círculos com ponto central). 
1.12. Mezilaurus subcordata (Ducke) Kosterm., Meded. Bot. Mus. Herb. Rijks Univ. Utrecht 25 (13): 40. 1936. Silvia subcordata Ducke, Arq. Jard. Bot. Rio de Janeiro 5: 112. 1930. Tipo: Brasil. Pará, Baixo Rio Jamundá, 17/05/1911, Ducke s.n. (lectótipo, escolhido por Kostermans (1938c), RB; isolectótipos, B [destruído], INPA, MO, U).

(Figura 26).

Árvores até $27 \mathrm{~m}$ alt. Ritidoma escamoso, marrom. Râmulos 2,5-5,5 (-7) mm diâm., cilíndricos a ligeiramente angulosos, marrom, marrom-esverdeados ou quase pretos, pubérulos próximo do ápice, com lenticelas conspícuas próximas do ápice; catafilos lanceolados, 3-6 mm compr., amarelos, dourados ou creme, pubescentes. Folhas alternas, 7,1-34 $\times(2,5-)$ 3,5-11,5 cm. Lâminas ovadas, lanceoladas, elípticas ou estreito-elípticas, 1,8-4 (-4,5) vezes mais longas que largas, faces abaxial e adaxial glabras a subglabras, base obtusa, arredondada ou subcordada, simétrica ou raro ligeiramente assimétrica, ápice acuminado a agudo, margem plana, pontuações glandulares na face abaxial, muitas vezes inconspícuas. Venação broquidódroma a ligeiramente broquidódroma, (6-9-) 12-20 nervuras por lado, impressa ou proeminente na face adaxial, proeminente na abaxial; nervuras secundárias formando um ângulo de 50-90 com a primária, juntando com as suprajacentes em ângulos retos ou obtusos; terciárias reticuladas ou percorrentes, oblíquas. Peciolo (9-) 29-70 (-75) × 1-4 mm, representando 17-29\% da folha, canaliculado, pubérulo, base ligeiramente dilatada,. Inflorescências do tipo duplo racemo (dibótrio) com ramos laterais umbeliformes, axilares ou próximas do ápice dos ramos, 8-12,1 cm compr., menores que as folhas, pubérulas; ramos laterais $0,5-2,2 \mathrm{~cm}$ compr., $10-15$ flores por ramo lateral; pedúnculos 2,2-4 cm compr. Bractéolas na base dos ramos laterais $1-1,2 \times 0,5-0,7$ $\mathrm{mm}$, uma bractéola na base dos pedicelos, $0,3-7 \times 0,2-0,4 \mathrm{~mm}$, triangulares, pubescentes a pubérulas, decíduas. Pedicelo 1-3 mm compr., pubérulos, tricomas não papilosos. Flores 1,5-2 mm diâm., 1,2-1,75 mm compr., amarelas a verdes, ligeiramente elipsoides ou globosas, externamente pubérulas, tricomas não papilosos. Tépalas subiguais a desiguais, quando 
desiguais, as internas são menores, externas $0,5-0,75 \times 0,6-1,25 \mathrm{~mm}$, internas $0,5-0,75 \times 0,5-$ 0,75 mm, ovadas, ápice obtuso a arredondado, margem papilosa, internamente pubescentes na base, menores que o receptáculo, $1 / 3$ do comprimento da flor, raramente próximas a $1 / 2$. Estames livres, $1-1,25 \times 0,75-1,2 \mathrm{~mm}$, exsertos na antese; anteras $0,5-0,6 \times 0,5-0,8 \mathrm{~mm}$, introrsas, triangulares, glabras frontalmente, pubescentes na face dorsal e papilosas no ápice; filetes $0,5-$ $0,75 \times 0,5-1,2 \mathrm{~mm}$, quadráticos ou retangulares, do mesmo tamanho a maiores que as anteras, pubescentes. Estaminódios ausentes ou raramente 1 por flor, pertencentes a série I do androceu, $0,75 \times 0,5 \mathrm{~mm}$, estipitiformes, pubescente. Pistilo 1,4-1,5 $\mathrm{mm}$ compr., pubérulo no ovário; ovário 0,7-0,75 mm compr., ovoide a elipsoide; estilete $0,7-0,75 \mathrm{~mm}$ compr., exserto na antese. Receptáculo 0,75-1 mm compr., pubescente internamente. Frutos até $26 \times 16 \mathrm{~mm}$, elipsoides a obovoides, glabros. Cúpulas 4,5-5,5 mm diâm., planas a pateliformes, externa e internamente pubérulas, diâmetros do mesmo tamanho ou ligeiramente maiores dos pedicelos na frutificação. Pedicelo na frutificação 2,5-5 mm compr., liso, pubérulo, bractéolas decíduas.

Material examinado: BOLÍVIA. Pando: km 17 Cobija a Campo Ana, 17/05/1977, fr., B. Menecés 605 (INPA). BRASIL. Amapá: Contagem entre Porto Platon e Serra do Navio, 10/1015/12/1976, veg., N. A. Rosa 1209 (MG). Acre: Brasiléia, Serringal Poromgaba, Colocação São José, $25 \mathrm{~km} \mathrm{~N}$ of km 4 Brasiléia-Assis Brasil Road (10² $\left.45^{\prime} \mathrm{S} / 68^{\circ} 45^{\prime} \mathrm{W}\right), 01 / 11 / 1991$, fl., D. C. Daly et al. 7080 (NY); entre Igarapé do Cujubim e Igarapé Jacumin, fazenda Bom Sossego, 27/09-7/10/1985, veg., D. G. Campbell et al. 8816 (MO). Mato Grosso: Aripuanã, 31/03/1977, fl., M. G. et al. 1089 (INPA); 25/01/1977, veg., M. Gomes et al. 566 (INPA); 17/02/1977, veg., M. Gomes et al. 772 (INPA); 17/02/1977, veg., M. Gomes et al. 792 (INPA); 01/03/1977, veg., M. Gomes et al. 888 (INPA); 04/05/1977, veg. M. Gomes et al. 1558 (INPA);12/05/1977, veg., M. Gomes \& C. Damião 1827 (INPA); 10/05/1977, veg., M. J. G. Gomes \& C. D. A. Mota 1722 (INPA); 10/03/1977, veg., S. Miranda 899 (INPA); 14/03/1977, veg., M. Gomes et al. 927 
(INPA); 18/04/1977, veg., M. G. et al. 1308 (INPA); 05/05/1977, veg., M. Gomes \& C. Damião 1622 (INPA); 09/05/1977, veg., M. G. \& C. D. A. Mota 1676 (INPA); 09/05/1977, veg., M. G. 1707 (INPA); 13/05/1977, veg., M. Gomes et al. 1872 (INPA); 21/02/1977, veg., M. Gomes et al. 847 (INPA); 03/05/1977, veg., M. Gomes \& C. Damião 1528 (INPA); 12/05/1977, veg., M. Gomes \& C. Damião 1834 (INPA); Núcleo do Aripuanã, 19/04/1977, veg., M. G. et al. 1329 (INPA); 19/05/1977, veg. M. Gomes \& C. Damião 1897 (INPA); 20/05/1977, veg. M. Gomes \& C. Damião 1910 (INPA); BR 174, Arredores do Aeroporto, projeto Juína, 04/06/1979, fr., M. G. Silva \& C. Rosário 4772 (HAMAB, HRB, INPA, MG, MO). Rondônia: Cacoal, Reserva Biológica do Jaru, margem do rio Ji-Paraná, 11-14/05/1987, veg., s.c. s.n. (SP 236696); Guajará Mirim, Chapada dos Pacaás, 09/04/1987, fl., C. A. C. Ferreira et al. 8772 (K, MO, NY). Roraima, Caracara, próximo a vila de Caicubi $\left(01^{\circ} 01^{\prime} 43 \mathrm{~S} / 62^{\circ} 05^{\prime} 21^{\prime \prime} \mathrm{W}\right), 14 / 02 / 2004$, veg., A. J. G. Soler \& E. F. Barbosa 214 (ESA, IAN, RB). PERU. Madre de Dios, Tambopata, 24/02/1984, fl., A. Gentry et al. 46116 (MO).

Distribuição e ecologia: Mezilaurus subcordata ocorre na Bolívia, Brasil e Peru, com registro de ocorrência para a porção norte, sul e sudoeste da Amazônia (Figura 25). A espécie está representada na sub-região Amazônica, ocorrendo nas províncias Roraima, Amapá, Várzea e Pantanal (Figura 1). Mezilaurus subcordata ocorre na floresta de terra firme e floresta ciliar não inundada, em solos argilosos, de 12 até $300 \mathrm{~m}$ de altitude.

Fenologia: Coletada com flores de fevereiro a maio e com frutos de maio a junho.

Etimologia: o epíteto subcordata é uma referência a suas lâminas foliares com base subcordada. Status de conservação: Mezilaurus subcordata apresenta distribuição geográfica ampla, porém, foi coletada apenas 2 vezes nos últimos 20. Portanto, é possível que Mezilaurus subcordata se encaixe a uma categoria de ameaçada de extinção em um futuro próximo. Por essa razão, a espécie deve ser avaliada como "Quase Ameaçada” (NT) IUCN (2001). 
Nome popular: itaúba, itaúba-abacate, itaúba-negra, louro-itaúba.

Importância econômica: Sua madeira já foi utilizada para a confecção de postes e estacas por ser resistente à água.

Mezilaurus subcordata é uma espécie bem definida dentro do gênero, caracterizada pelas lâminas foliares glabras, base obtusa, arredondada ou subcordada, pecíolo representando 17-29\% da folha, canaliculado, inflorescências do tipo duplo racemo (dibótrio) com ramos laterais umbeliformes, flores pubérulas, tépalas menores que o receptáculo, anteras introrsas e pistilo com ovário pubérulo.

Além de M. subcordata, estames introrsos podem ocorrer também em M. introrsa. Mezilaurus introrsa apresenta, entretanto, base foliar aguda ou decorrente, pecíolo pubérulo e representando $11-13 \%$ da folha, flores glabras e ovário glabro. 


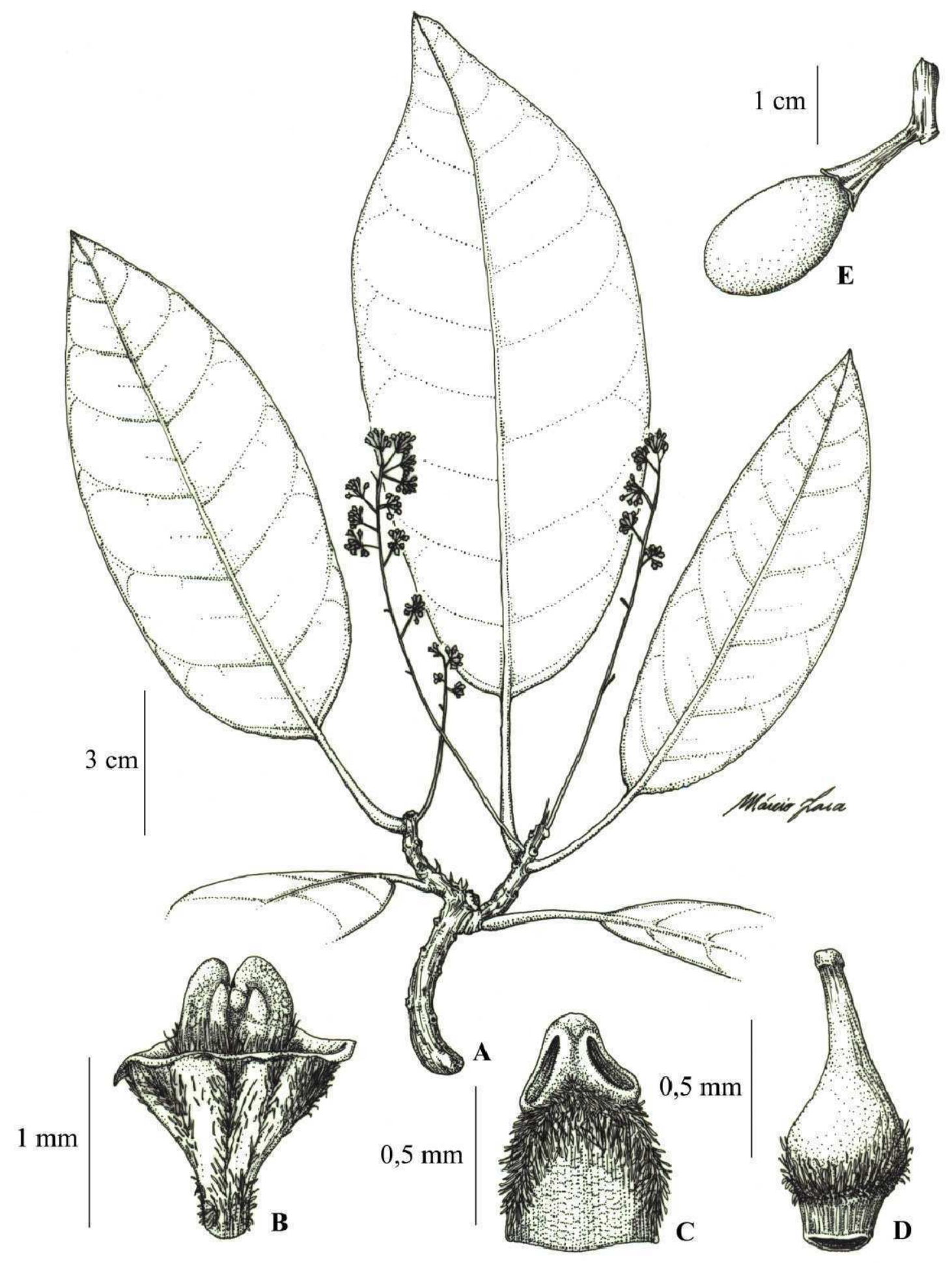

Figura 26: Ilustração de Mezilaurus subcordata. A: ramo com flores; B: flor; C: estame; D: pistilo (M. G. et al. 1089); E: fruto (Menecés 605). 
1.13. Mezilaurus synandra (Mez) Kosterm., Meded. Bot. Mus. Herb. Rijks Univ. Utrecht 25 (13): 40. 1936. Silvia synandra Mez, Repert. Spec. Nov. Regni Veg. 16: 306. 1920. Tipo: Brasil. Amazonas, Manaus, Pensador, 06/1910, Ule 8835 (lectótipo, escolhido por Kostermans (1938c), B [destruído]; lectótipo designado aqui, L; isolectótipos, MG, US).

(Figura 27).

Árvores até $25 \mathrm{~m}$ alt. Ritidoma escamoso, marrom a marrom-avermelhado. Râmulos 3,5-7 mm diâm., cilíndricos, marrom, marrom-esverdeados a ligeiramente pretos, pubescentes a pubérulos próximo ao ápice, com lenticelas conspícuas próximas do ápice; catafilos ovados a lanceolados, 1-3 mm compr., creme a amarelos, pubescentes a seríceos. Folhas alternas, 2,6-28,9 × 1,3-11,2 cm. Lâminas elípticas, estreito-elípticas ou obovadas, 1,6-3,7 vezes mais longas que largas, faces abaxial e adaxial glabras a subglabras, base aguda, cuneada, raramente decorrente, simétrica, ápice obtuso, arredondado ou retuso, raro agudo, ligeiramente acuminado, emarginado ou obcordado, margem plana ou muito ligeiramente revoluta, principalmente na base, pontuações glandulares presentes ou ausentes. Venação broquidódroma a ligeiramente broquidódroma, 7-22 nervuras por lado, proeminente nas faces adaxial e abaxial; nervuras secundárias formando um ângulo de $50-90^{\circ}$ com a primária, juntando com as suprajacentes em ângulos retos; terciárias reticuladas ou percorrentes, oblíquas. Pecíolo (4-) 19-50 (-62) × 1-4 mm, representando (5-) 11-31\% da folha, plano a ligeiramente canaliculado, glabro a subglabro ou pubérulo, base dilatada. Inflorescências do tipo duplo racemo (dibótrio) com ramos laterais umbeliformes, axilares ou próximas do ápice dos ramos, 1,4-7,5 cm compr., menores que as folhas, pubérulas; ramos laterais $0,5-0,9 \mathrm{~cm}$ compr., 3-6 flores por ramo lateral; pedúnculos $0,5-3,7 \mathrm{~cm}$ compr. Bractéolas na base dos ramos laterais $0,75-1 \times 0,3-0,5 \mathrm{~mm}$, uma bractéola na base dos pedicelos, 0,2-0,5 mm compr., 0,2-0,7 mm larg., triangulares a ovadas, pubérulas, decíduas. Pedicelo 1-2,5 mm compr., pubescentes a pubérulos, tricomas não papilosos. Flores 1,75-2,5 mm diâm., 1,52,4 mm compr., amarelas a verdes, depressas, externamente pubérulas, tricomas não papilosos. 
Tépalas iguais a ligeiramente desiguais, quando desiguais, externas maiores, externas $0,5-1 \times$ 0,75-1,5 mm, internas $0,5-0,8 \times 0,5-1,25 \mathrm{~mm}$, ovadas, ápice obtuso, margem papilosa, internamente pubérulas, do mesmo tamanho a maiores que o receptáculo, $1 / 2$ do comprimento da flor ou ligeiramente maiores. Estames conados, 1-1,25 × 0,75-1,1 mm, inclusos na antese, raro exsertos; anteras ca. $0,5 \times 0,75 \mathrm{~mm}$, extrorsas, triangulares, glabras frontalmente, pubescentes face dorsal, papilosas no ápice; filetes $0,5-1 \times 0,75-1,25 \mathrm{~mm}$, quadráticos ou retangulares, do mesmo tamanho a maiores que as anteras, pubescentes. Estaminódios ausentes. Pistilo 1,25-2 mm compr., pubescente; ovário $0,75-1,5 \mathrm{~mm}$ compr., ovoide; estilete $0,4-0,5 \mathrm{~mm}$ compr., exserto na antese. Receptáculo 0,5-0,75 mm compr., pubérulo internamente. Frutos até $29 \times 22$ mm, elipsoides, pubescentes no ápice. Cúpulas 4-5,5 $\mathrm{mm}$ diâm., planas a pateliformes, externamente pubérulas ou subglabras, internamente pubescentes, diâmetros iguais ou ligeiramente maiores que os pedicelos na frutificação, raro ligeiramente menor. Pedicelo na frutificação 3,5-5 mm compr., liso, pubérulos ou subglabros, bractéolas decíduas.

Material Examinado: BRASIL. Amazonas. Manacapurú, Paraná do Jacaré, Lago do Paracúuba, 21/03/1979, veg., D. Coêlho et al. s.n. (INPA); Manaus, 18/05/1932, fl., fr., A. Ducke s.n. (G, K, P, RB); 20/06/1933, fl., fr., A. Ducke s.n. (K, P, RB, U); porto de Manaus, baixo rio Negro, região de Cacau Perera, 10/06/1970, fl., W. Rodrigues \& S. R. Jaccoud 8884 (INPA, MBM, MO); estrada da Forquilha, 04/05/1956, fl., D. F. Coelho s.n. (INPA, MG, RB); estrada para Caracaraí, 16/06/1970, fl., P. Cavalcante 2717 (MG); Parque 10, 22/06/1956, fl., D. Coelho s.n. (INPA, MG, MO, RB); Reserva Florestal Ducke, 15/09/1994, fl., fr., A. Vicentini et al. 753 (INPA, K [2 exsicatas], SP); 09/04/2008, fl., F. M. Alves 522 (ESA, SPF); Igarapé da Cachoeira Baixa, 02/09/1955, fr., W. A. Rodrigues s.n. (INPA); perto do Pensador, 20/06/1933, veg., A. Ducke s.n. (INPA); 20/06/1933, fl., A. Ducke s.n. (INPA); Cachoeira alta do Tarumã, 27/07/1961, fr., W. Rodrigues \& J. Lima 3047 (INPA, NY); estrada Manaus-Itacoatiara, 20/09/1965, veg., W. 
Rodrigues 7982 (INPA); Ponte da Bolívia, 18/05/1972, flor, M. Silva et al. 99 (INPA); estrada Manaus-Itacoatiara km 69, 26/08/1965, veg., W. Rodrigues 7981 (INPA); estrada ManausItacoatiara km 60, 11/1975, fl., D. Coêlho 613 (INPA); Cachoeira baixa do Tarumã, 20/06/1955, fl., J. Chagas s.n. (INPA, MG); estrada Manaus-Itacoatiara km 68, 05/03/1970, fr., W. Rodrigues 8729 (INPA); Pensador, 10/07/1936, fl., A. Ducke 233 (K, MG, NY); 02/09/1942, fr., A. Ducke 239 (IAN); Manaus, Ponta Negra, 10/1970, fr., M. F. Silva \& L. Coêlho 25 (INPA); campina do Igarapé do Leão, 10/03/1970, fl., W. Rodrigues 8746 (INPA); Ponte Negra, Hotel Tropical, 19/07/1977, fl., W. Rodrigues 9986 (INPA); Hotel Tropical, 19/07/1977, veg., W. Rodrigues 9994 (INPA); Rio Negro, Preto, Maboaby, 17/11/1947, veg., R. L. Froés 22878 (IAN); Rio Urubú, terra alta ao longo do Rio, 24/09/1949, fr., R. L. Froés 25399 (MG); 7 km ao sul da parte

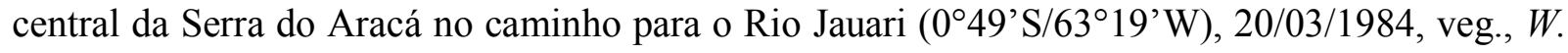
Rodrigues et al. 11134 (INPA). Bahia. Una, Fazenda Rafael, 05/11/1969, fl., T. S. dos Santos 468 (BHCB, CEPEC, SPSF). Tocantins. Porto Nacional, estrada a esquerda a partir da estrada para Barrolândia que sai da Vila Graciosa (1008'30''S/48²6'23'’W), 13/01/1999, fl., G. F. Árbocz 6476 (HTINS, IBGE).

Distribuição e ecologia: Mezilaurus synandra é restrita ao Brasil e ocorre nos estados do Amazonas, Tocantins e Bahia. A espécie é característica da Amazônia central, muito coletada na região de Manaus e com somente uma coleta nos estados do Tocantins e Bahia (Figura 28). Mezilaurus synandra ocorre na sub-região Amazônica, províncias de Roraima, Várzea e Madeira; sub-região Chaquenha, província do Cerrado; sub-região Paranaense, província da Floresta Atlântica Brasileira (Figura 1). A espécie ocorre na floresta de terra firme, mata de várzea, floresta devastada (capoeira aberta), mata de carrasco, matas ciliares e matas secundárias na Amazônia, Cerrado alto no estado do Tocantins e na floresta de tabuleiro na Floresta Atlântica do sul da Bahia. 
Fenologia: Coletada com flores em janeiro, março a julho, setembro a novembro e frutos em janeiro, março, maio a julho, setembro e outubro.

Etimologia: O epíteto synandra é uma referência aos estames nas flores unidos.

Status de conservação: Mezilaurus synandra apresenta distribuição ampla e com material coletado recentemente. Portanto, a espécie deve ser considerada como "Menor Preocupação" (LC) (IUCN 2001).

Nome popular: itaúba, itaúba-amarela, itaúba-chichica, itaúba-de-folha-miúda, itaúba-surubim, louro-itaúba, louro-itaúba-abacate (Amazônia Central) e louro-pimenta (Bahia).

Importância econômica: Sua madeira é provavelmente utilizada para a fabricação de embarcações na Amazônia, já que a espécie também é conhecida como "itauba" e amplamente encontrada na região de Manaus no Brasil.

Mezilaurus synandra apresenta-se caracterizada por lâminas glabras a subglabras, inflorescências do tipo duplo racemo (dibótrio) com ramos laterais umbeliformes, flores pubérulas e depressas, tépalas do mesmo tamanho a maiores que o receptáculo, $1 / 2$ do comprimento da flor ou ligeiramente maiores, estames conados, pistilo pubescente e fruto pubescente no ápice.

A espécie apresenta características semelhantes a $M$. itauba, entretanto, esta última possui tépalas menores que o receptáculo, cerca de $1 / 3-1 / 4$ do comprimento da flor, estames livres, ovário glabro e frutos glabros no ápice.

Mezilaurus synandra é semelhante e pode ser confundida à M. revolutifolia, com ambas ocorrendo no estado brasileiro da Bahia. Mezilaurus revolutifolia apresenta, todavia, lâminas foliares revolutas, flores glabras, receptáculo glabro internamente, estames livres, pistilo glabro e fruto glabro. No nordeste do Brasil, M. synandra é conhecida somente para o município de Una, sul da Bahia, enquanto M. revolutifolia ocorre no nordeste do estado. 
Béguin et al. (1985) citaram Mezilaurus synandra para a província de Requena, departamento de Loreto no Peru. As coletas citadas foram Bernard s.n. (arbre 7-58) e Bernardi 16227 (arbre 7-64). Na figura sete do trabalho, os autores apresentaram o desenho do pistilo da espécie como glabro, portanto, não se tratando de M. synandra. Após análise dessas coletas, verificou-se que tais tratam-se de $M$. itauba.

Rodrigues et al. 11134 é colocado aqui com exitação, pois as lâminas foliares são estreitoelípticas com ápice agudo a ligeiramente acuminado e base decorrente. Entretanto, as nervuras proeminentes na face adaxial corroboram a inclusão do exemplar em M. synandra.

Mez (1920) descreveu Silvia synandra com o síntipo Ule 8835, todavia, o autor não indicou em qual herbário estaria depositado esse material de referência. Kostermans (1938c) lectotipificou (inferencialmente) o exemplar depositado no herbário de Berlim na Alemanha (B). Porém, o exemplar Ule 8835, depositado neste herbário foi destruído durante a Segunda Guerra Mundial. Por essa razão, foi escolhido aqui um lecótipo, depositado no Nationaal Herbarium Nederland, Leiden University branch, Leiden, Holanda (L). 


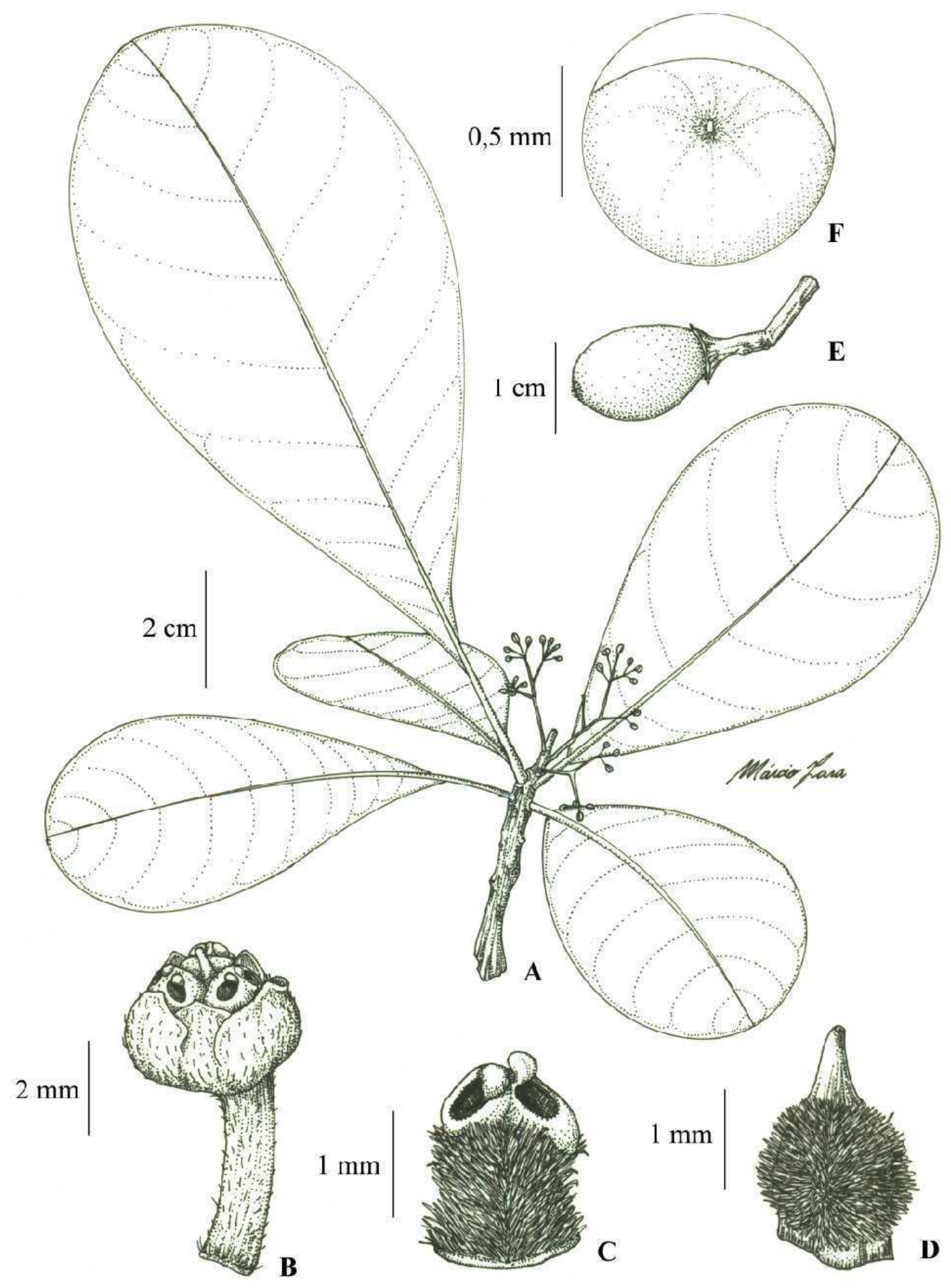

Figura 27: Ilustração de Mezilaurus synandra. A: ramo com flores; B: flor; C: estame; D: pistilo (Rodrigues \& Jaccoud 8884); E: fruto; F: detalhe do fruto pubescente no ápice (Silva \& Coêlho 25). 


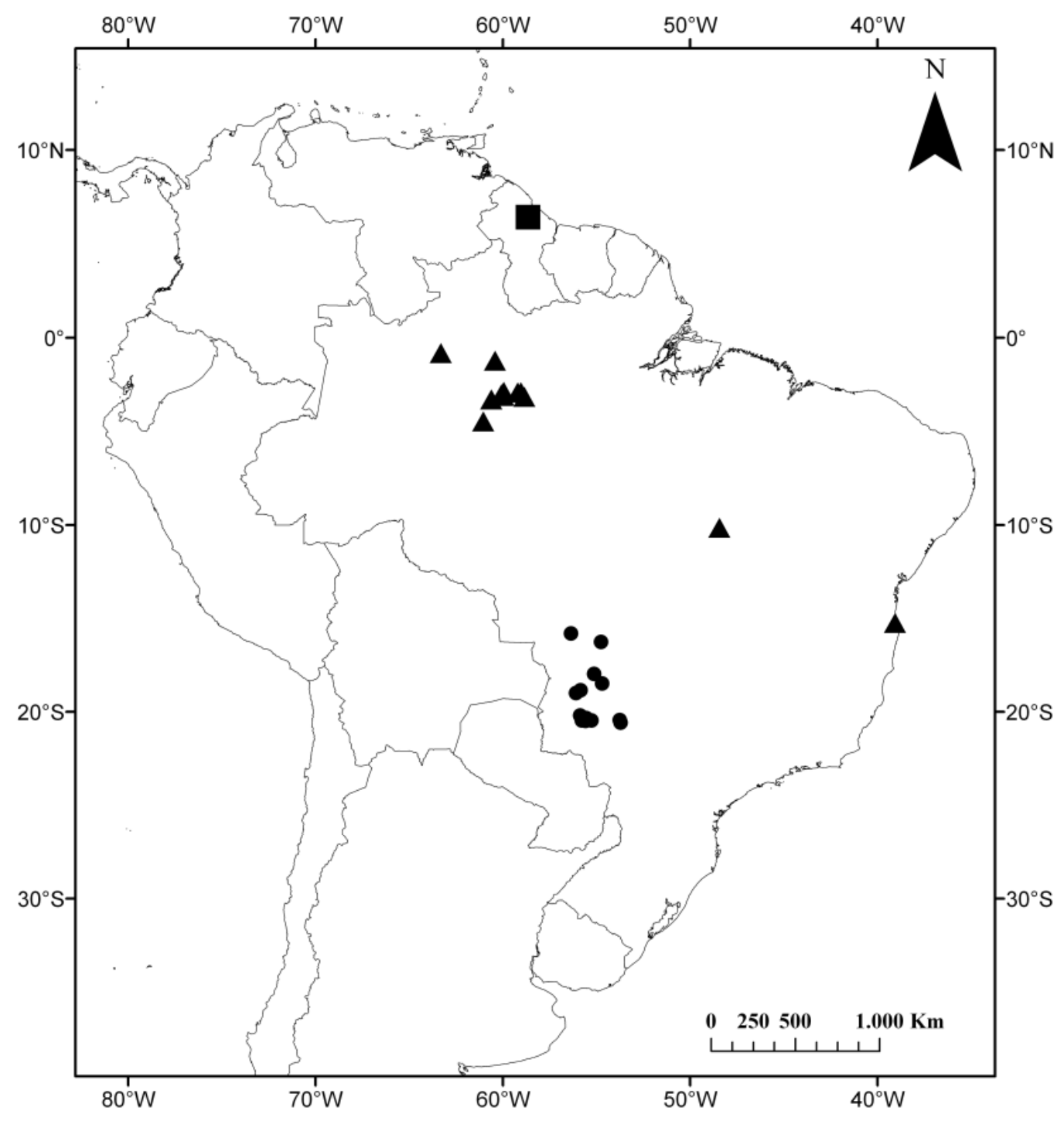

Figura 28: Mapa de distribuição geográfica de Mezilaurus synandra (triângulos), $M$. thoroflora (quadrado) e M. vanderwerrfii (pontos). 
1.14. Mezilaurus thoroflora van der Werff, Ann. Missouri Bot. Gard. 74: 179. 1987. Licaria maguireana C. K. Allen, Bull. Torrey Bot. Club 75: 315. 1948. Misanteca maguireana (C. K. Allen) Lundell, Wrightia 4 (3): 100. 1969. Clinostemon maguireanum (C. K. Allen) Kurz, J. Arnold Arbor. 60: 520. 1979. Tipo: British Guiana. Mazaruni Station, 30/06/1939, Forest Departament of British Guiana Record No. 2956/Field No. 220 (holótipo, NY; isótipo, K [3 exsicatas]).

(Figura 29).

Árvores até $24 \mathrm{~m}$ alt. Ritidoma fissurado, cinza. Râmulos 8-9 mm diâm., cilíndricos, marrom, pubescentes, com lenticelas conspícuas próximas do ápice; catafilos ovados, 7-11 mm compr., amarelos a creme, pubescentes. Folhas alternas, 21-66,7 × 6-17,3 cm. Lâminas oblanceoladas, 3,4-3,8 vezes mais longas que largas, face abaxial pubérulas, adaxial pubérulas a subglabras, base atenuada, simétrica, ápice agudo a acuminado, margem plana ou ligeiramente revoluta no ápice, pontuações glandulares ausentes. Venação ligeiramente broquidódroma, 23-28 nervuras por lado, impressa na face adaxial, proeminente na abaxial; nervuras secundárias formando um ângulo de $70-85^{\circ}$ com a primária, juntando com as suprajacentes em ângulos agudos a obtusos; terciárias percorrentes, oblíquas. Peciolo 5-12 4 4 $7 \mathrm{~mm}$, representando $1-2 \%$ da folha, plano a ligeiramente canaliculado no ápice, pubescente, base dilatada. Inflorescências do tipo duplo racemo (dibótrio) com ramos laterais não umbeliformes, axilares ou próximas do ápice dos ramos, $30-51 \mathrm{~cm}$ compr., maiores ou menores que as folhas, raque principal pubérula, ramos laterais pubérulos a subglabros; ramos laterais $0,7-3,4 \mathrm{~cm}$ compr., 5-20 flores por ramo lateral; pedúnculos 10-15 cm compr. Bractéolas na base dos ramos laterais, 1,25-2 × 0,5-0,75 mm, uma bractéola na base dos pedicelos, $0,5-0,75 \times 0,2-0,3 \mathrm{~mm}$, ovadas a triangulares, pubescentes a pubérulas, persistentes. Pedicelo 2-8 mm compr., glabro. Flores 1-1,75 mm diâm., 1,5-2,25 mm compr., amarelo-claras, elipsoides, externamente glabras. Tépalas iguais ou subiguais, quando subiguais externas ligeiramente menores, tépalas externas $0,4-0,5 \times 0,4-0,5 \mathrm{~mm}$, internas $0,5-0,6$ 
$\times 0,5-0,75 \mathrm{~mm}$, ovadas, ápice obtuso, margem papilosa, internamente pubescentes, menores que o receptáculo, $1 / 4^{-1} / 5$ do comprimento da flor. Estames livres, $1-1,2 \times 0,5-0,6 \mathrm{~mm}$, exsertos na antese; anteras $0,5-0,6 \times 0,5-0,6 \mathrm{~mm}$, extrorsas, triangulares, glabras frontalmente, pubescentes na face dorsal, não papilosas; filetes $0,5-0,6 \times 0,6-0,7 \mathrm{~mm}$, quadráticos ou retangulares, ligeiramente maiores que as anteras, pubescentes. Estaminódios 9, representando as séries I, II e IV do androceu, $0,6-0,75 \times 0,2-0,3 \mathrm{~mm}$, sagitados a lanceolados, pubescentes. Pistilo ca. $1,8 \mathrm{~mm}$ compr., glabro; ovário $0,8-1,2 \mathrm{~mm}$ compr., elipsoide; estilete $0,6-1 \mathrm{~mm}$ compr., exserto na antese. Receptáculo 1-1,5 mm compr., pubescente internamente. Frutos até $19 \times 10 \mathrm{~mm}$, elipsoides, glabros. Cúpulas 5-6,5 mm diâm., planas a pateliformes, externamente glabras, internamente pubescentes, diâmetros menores que os pedicelos na frutificação. Pedicelo na frutificação 9-13 mm compr., liso, glabro, bractéolas persistentes.

Parátipo: GUIANA: Mazaruni Station, 15/07/1938, fl., Forest Departament of British Guiana Field No. 105, Record No. 2704 (K [2 exsicatas]).

Distribuição e ecologia: Mezilaurus thoroflora ocorre somente na Guiana, conhecida apenas para Mazaruni Station, norte do país (Figura 28). A espécie ocorre na sub-região Amazônica, representada para a província da Guiana Úmida (Figura 1); na floresta ombrófila, localmente chamada de "secundary greenheart bush on level brown sand".

Fenologia: Flores coletadas em junho e julho e frutos em julho.

Etimologia: O epíteto thoroflora é uma referência à semelhança entre as flores pequenas com longos pedicelos da espécie com um espermatozoide (van der Werff 1987).

Status de conservação: A espécie possui distribuição restrita, conhecida somente por dois espécimes e uma localidade, Mazaruni Station na Guiana. Por essa razão, a espécie deve ser considerada, utilizando as categorias e critérios da IUCN (IUCN 2001), como "Criticamente em Perigo" (B1a). 
Nome popular: desconhecido

Importância econômica: A espécie é citada como aromática por seus coletores.

Mezilaurus thoroflora é uma espécie bastante distinta, caracterizada por apresentar folhas grandes, 21-66,7 × 6-17,3 cm, lâminas oblanceoladas, pubérulas na face abaxial, inflorescências do tipo duplo racemo (dibótrio) (ramos laterais não umbeliformes) 30-51 cm compr., bractéolas persistentes até a frutificação, flores elipsoides, nove estaminódios, representando as séries I, II e IV do androceu, pedicelos na frutificação 9-13 mm, cúpulas 5-6,5 mm diâm., diâmetros menores que os pedicelos na frutificação.

Mezilaurus thoroflora é semelhante à M. duckei, principalmente por compartilharem folhas grandes, se comparado com o restante do gênero, lâminas foliares pubérulas na face abaxial, nove estaminódios, representando as séries I, II e IV do androceu e bractéolas persistentes até a fase de frutificação. Mezilaurus duckei apresenta, no entanto, flores globosas ou ligeiramente elipsoides, estames inclusos na antese, pedicelos no frutificação 1,25-2,5 mm compr. e cúpulas 2,5-4,5 mm diâm. com diâmetros maiores que os pedicelos na frutificação.

Além das duas espécies citadas anteriormente, Clinostemon mahuba, que já foi tratada como Mezilaurus por van der Werff (1987), também possui nove estaminódios representando as séries I, II e IV do androceu e bractéolas persistentes até a frutificação. Clinostemon mahuba apresenta, porém, flores pubescentes a pubérulas, três bractéolas na base dos pedicelos, anteras encurvadas e filetes com um par de glândulas. 


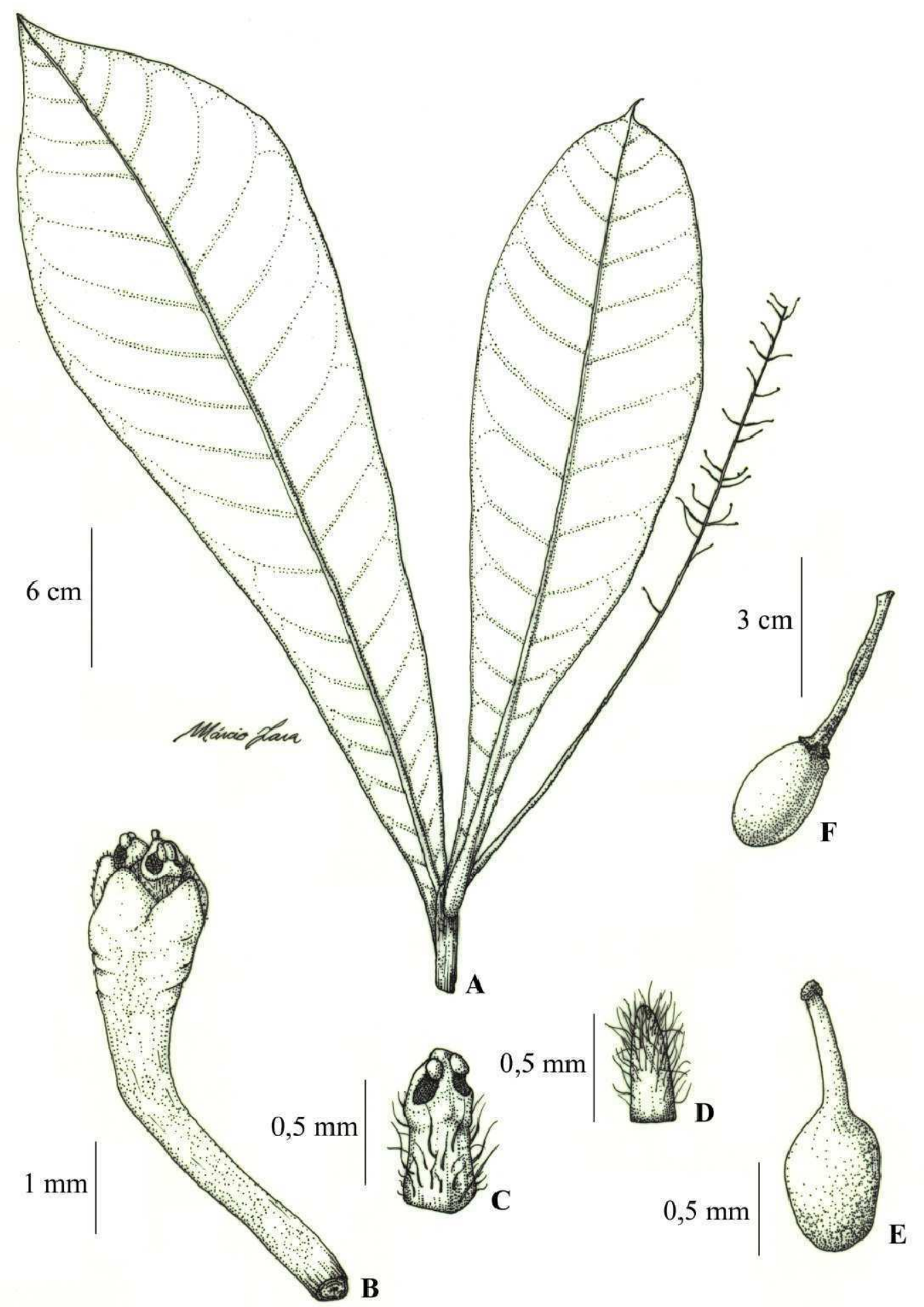

Figura 29: Ilustração de Mezilaurus thoroflora. A: ramo com flores; B: flor; C: estame; D: estaminódio da série I do androceu; E: pistilo (isótipo); F: fruto (parátipo). 
1.15. Mezilaurus vanderwerffii F. M. Alves \& J. B. Baitello, Acta Bot. Bras. 22(2): 356. 2008. Tipo: Brasil. Mato Grosso do Sul, Ribas do Rio Pardo, 03/04/1994, H. Lorenzi 1467 (holótipo, SPSF; isótipo, HPL).

(Figura 30).

Árvores até $18 \mathrm{~m}$ alt. Ritidoma escamoso, cinza. Râmulos 2,5-5 mm diâm., cilíndricos, marrom, seríceos a ligeiramente tomentoso, com lenticelas conspícuas próximas do ápice; catafilos lanceolados, 2-5mm compr., amarelos, seríceos. Folhas alternas, 4,3-17 × 1,9-7 cm. Lâminas elípticas a obovadas, 1,7-2,9 vezes mais longas que largas, glabras a subglabras, base aguda a decorrente, simétrica, ápice agudo a obtuso, margem plana, pontuações glandulares nas faces abaxial e adaxial. Venação broquidódroma a ligeiramente broquidódroma, 8-17 nervuras por lado, impressa ou proeminente na face adaxial, proeminente na abaxial; nervuras secundárias formando um ângulo de $50-80^{\circ}$ com a primária, juntando com as suprajacentes em ângulos agudos ou retos; terciárias reticuladas ou percorrentes, oblíquas. Peciolo 1-7 × 1,5-3 mm larg., representando $1-8 \%$ da folha, plano a ligeiramente canaliculado, pubérulo, base ligeiramente dilatada. Inflorescências do tipo duplo racemo (dibótrio) com ramos laterais umbeliformes, axilares ou próximas ao ápice dos ramos, 3,2-5,2 cm compr., menores que as folhas, raque principal pubérula a subglabra, ramos laterais glabros; ramos laterais $0,6-1,2 \mathrm{~cm}$ compr., $2-5$ flores por ramo lateral; pedúnculos 0,9-3,5 cm compr. Bractéolas na base dos ramos laterais, $1-$ $1,25 \times 0,5-0,75 \mathrm{~mm}$, uma bractéola na base dos pedicelos, $0,75-1 \times 0,25-0,4 \mathrm{~mm}$, triangulares, glabras ou com poucos tricomas na margem e ápice. Pedicelo 1,25-3 mm compr., glabro a subglabro, tricomas não papilosos. Flores 2-2,25 mm diâm., 1,8-2,25 mm compr., verdes a verde-amareladas, ligeiramente elipsoides a ligeiramente depressas, externamente glabras. Tépalas iguais a subiguais, quando subiguais, internas ligeiramente menores, externas ca. $0,5-1 \times$ 0,25-1 mm, internas ca. 0,8-1 × 0,75-1 mm, ovadas, ápice obtuso a arredondado, margem ligeiramente papilosa, internamente pubescentes na base, do mesmo tamanho do receptáculo ou 
ligeiramente menor, ca. $1 / 2$ do comprimento da flor, nunca chegando a $1 / 3$. Estames livres, $1-1,8 \times$ 0,75-1 mm, exsertos em antese; anteras $0,6-0,75 \times 0,6-0,75 \mathrm{~mm}$, extrorsas ou latrorsas, triangulares, glabras frontalmente, pubescentes na face dorsal, não papilosas; filetes $0,5-0,75 \times$ 0,5-0,75 mm, quadráticos ou retangulares, do mesmo tamanho a maiores que as anteras, pubescentes. Estaminódios ausentes ou raramente 1 por flor, pertencentes as séries I ou IV do androceu, $0,75 \times 0,5 \mathrm{~mm}$, estipitiformes, pubescentes. Pistilo 1,5-1,75 $\mathrm{mm}$ compr., pubérulo a subglabro no ovário; ovário $0,75-1 \mathrm{~mm}$ compr., ovoide a elipsoide; estilete $0,5-0,75 \mathrm{~mm}$ compr., ligeiramente exserto na antese ou no mesmo nível das tépalas. Receptáculo $0,75-1 \mathrm{~mm}$ compr., pubescente internamente. Frutos até $27 \times 18 \mathrm{~mm}$, elipsoides a obovoides, glabros ou pubérulos na base. Cúpulas 3,5-5 mm diâm., planas a pateliformes, externamente glabro, internamente pubescente, diâmetros dos mesmos tamanhos ou ligeramente maiores que os pedicelos na frutificação. Pedicelo na frutificação 2,5-5 mm compr., fissurado, glabro.

Material examinado: BRASIL. Mato Grosso: Gt. Livramento Poconé, $10 \mathrm{~km}$ do Mun. N. S. Livramento, 19/04/1983, fr., M. Macedo \& S. Assunção 1758 (UEC); Rondonópolis, BR 367, próximo a estação 14, 27/01/1977, bot., J. S. Costa 110 (HRB [2 exsicatas], MO, RB). Mato Grosso do Sul: Aquidauana, Piraputanga, 18/07/1993, fl., fr., H. Lorenzi s.n. (SPSF); estrada para Piraputanga, 13/05/2006, veg., F. M. Alves \& W. Garcez 44 (CGMS); estrada para o Morro do Paxixi, 13/05/2006, fl., fr., F. M. Alves \& W. Garcez 45 (CGMS, ESA, MBM); pesqueiro da Serra, 11/11/1997, fl., Resende, U. M. 1032 (CGMS, ESA, SPSF); Close to the entrence of Faz. Sonho Lindo, $26 \mathrm{~km}$ from Cipolândia on the road to Aquidauana $\left(20^{\circ} 12^{\prime} \mathrm{S} / 55^{\circ} 53 \mathrm{~W}\right), 24 / 09 / 1996$, fr., J. A. Ratter et al. 7517 (CPAP, E, UB); estrada do Paxixi, 26/10/86, bot., S. T. Vasconcelos et al. 34 (COR, UB); distrito de Piraputanga, 02/04/1994, fl., fr., H. Lorenzi 1495 (HPL); Campo Grande, BR 262, cerca de $70 \mathrm{~km}$ de Campo Grande, 25/05/1998, veg., E. R. Salviani \& H. Lorenzi 5 (HPL); Corumbá, Faz. Campo Alto, Vasante Batatal, Nhecolândia-Pantanal 
(1901'S/5606'W), 22/04/1990, fr., A. Pott 5582 et al. (CPAP, E, MBM); Faz. Imaculada, invernada São Benzinho, 18/05/2000, fr., S. Salis et al. 1142 (K); Coxim, Faz. Buriti Alegre,

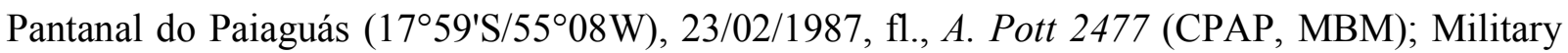

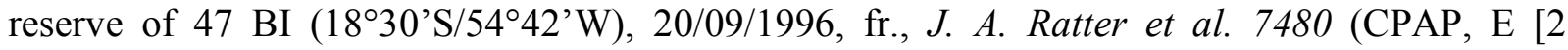
exsicatas], INPA, UB); Ribas do Rio Pardo, $1 \mathrm{~km}$ a oeste da cidade na BR 262 para Campo Grande, 07/11/1996, veg., J. A. Ratter et al. $7637 \mathrm{~V}$ (E, UB); margem da Rodovia 262, 28/09/1994, fr., G. F. Árbocz 792 (SPSF).

Distribuição e ecologia: Mezilaurus vanderwerffii apresenta ocorrência restrita ao Brasil, registrada para os estados do Mato Grosso e Mato Grosso do Sul (Figura 28). A espécie ocorre na sub-região Amazônica, província do Pantanal e sub-região Chaquenha província do Cerrado (Figura 1). Mezilaurus vanderwerffii é uma espécie característica do Cerrado, floresta estacional e na transição entre essas duas formações do Pantanal matogrossense e sul-matogrossense e seu entorno, em solos arenosos entre 140 e $430 \mathrm{~m}$ de altitude.

Fenologia: Coletada com flores em janeiro, fevereiro, abril, maio e outubro e novembro, frutos em abril, maio e setembro.

Etimologia: O epíteto vanderwerffii é uma homenagem ao estudioso e autor de inúmeros trabalhos com Lauraceae Henk van der Werff (Alves \& Baitello 2008).

Status de conservação: Mezilaurus vanderwerffii possui distribuição geográfica restrita ao centro-oeste do Brasil, porém, com grande quantidade de espécimes coletados recentemente. Portanto, a espécie deve ser considerada como "Menor Preocupação" (LC), utilizando os critérios da IUCN (2001).

Nome popular: tapinhoã, canela-amarela, caneleira-amarela.

Importância econômica: A madeira de Mezilaurus vanderwerffiii, por ser dura e pesada, é utilizada localmente para moirões, postes, cruzetas, dormentes, carpintaria em geral, armações de 
pontes, obras hidráulicas e outras obras externas que requeiram resistência mecânica e grande durabilidade da madeira. A árvore possui copa ornamental, recomendada para a arborização paisagística e reflorestamento com objetivos preservacionistas (Lorenzi 2002). Os frutos são comestíveis, com sabor semelhante ao do abacate e, segundo Alves \& Baitello (2008), apreciados pela avifauna, especialmente por tucanos.

Mezilaurus vanderwerffii é caracterizada por lâminas foliares elípticas a obovadas, glabras a subglabras, inflorescências do tipo duplo racemo (dibótrio) com ramos laterais umbeliformes, raque principal da inflorescência subglabra a pubérula, ramos laterais glabros, flores glabras, receptáculo pubescente internamente, tépalas do mesmo tamanho que o receptáculo ou ligeiramente menor, ca. $1 / 2$ do comprimento da flor, nunca chegando a $1 / 3$, estames livres, extrorsos e pedicelo na frutificação com superfícies fissuradas.

Mezilaurus vanderwerffii pode ser confundida com $M$. itauba, entretanto, esta última possui inflorescências pubérulas, flores pubescentes a pubérulas ou raramente glabras, tépalas menores que o receptáculo, $1 / 3^{1}-{ }^{1}(-1 / 5)$ do comprimento da flor e pedicelo na frutificação com superfície lisa.

Mezilaurus crassiramea apresenta também registro de ocorrência para o Mato Grosso e Mato Grosso do Sul. A espécie apresenta, no entanto, lâminas foliares na face abaxial hirsutas, vilosas a lanosas, inflorescências do tipo duplo racemo (dibótrio) com ramos laterais não umbeliformes, bractéolas persistentes e tépalas menores que o receptáculo, $1 /{ }_{3}-1 / 4$ do tamanho da altura da flor. 


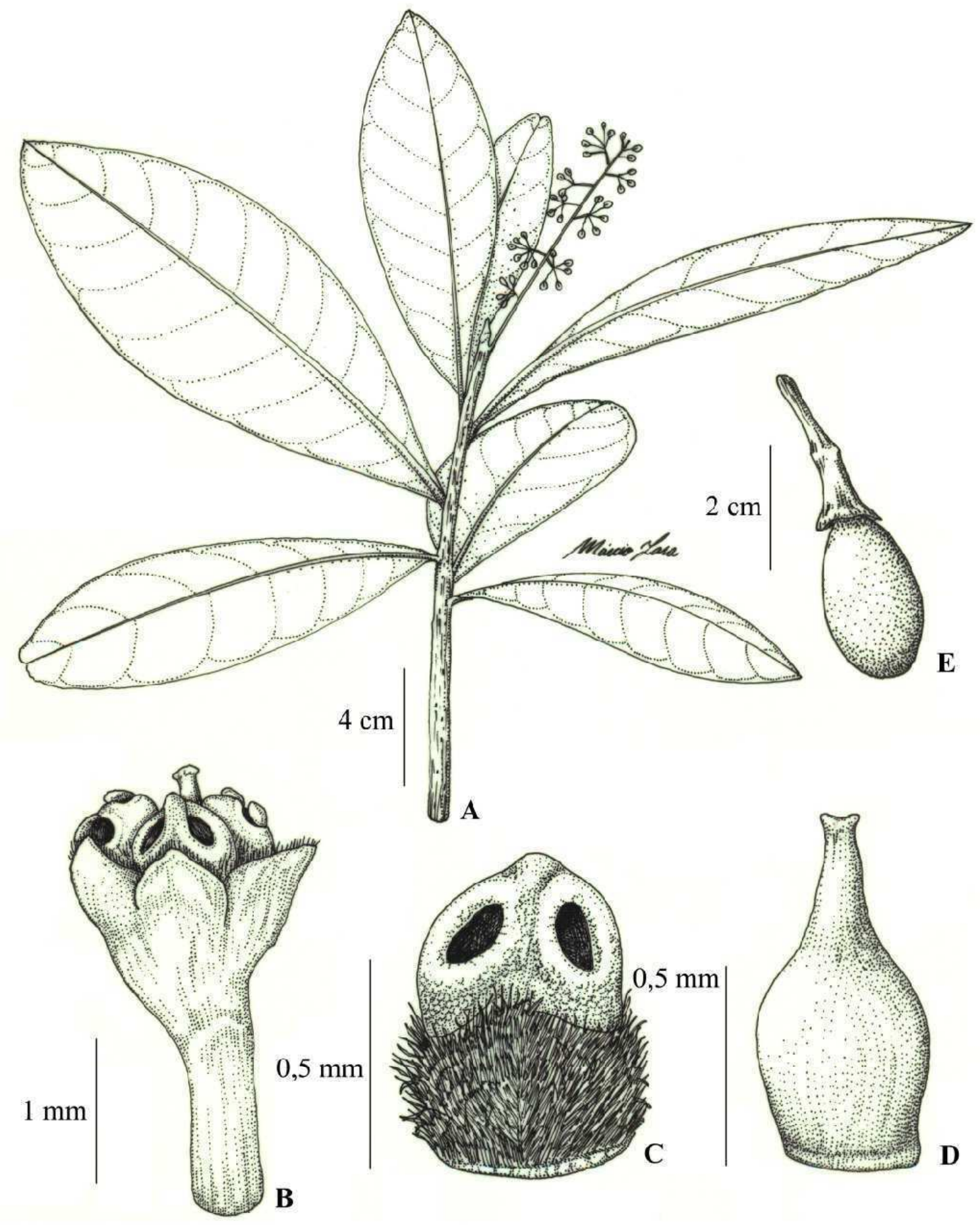

Figura 30: Ilustração de Mezilaurus vanderwerffii. A: ramo com flores; B: flor; C: estame; D: pistilo (parátipo: Resende 1032); E: fruto (Alves \& Garcez 45). 


\section{Nomes excluídos}

Mezilaurus glaucophylla van der Werff $\equiv$ Williamodendon glaucophyllum (van der Werff) Kubitzki \& H. G. Richt.

Mezilaurus mahuba (A. Samp.) van der Werff $\equiv$ Clinostemon mahuba (A. Samp.) Kuhlm. \& A. Samp.

Mezilaurus oppositifolia (Nees) Taub. ex Mez $\equiv$ Licaria oppositifolia (Nees) Kosterm.

Mezilaurus quadrilocellata van der Werff $\equiv$ Williamodendon quadrilocellatum (van der Werff) Kubitzki \& H. G. Richt. = Williamodendron spectabile Kubitzki \& H. G. Richt. (nomem superfluo).

Mezilaurus matogrossensis J. A. Ratter, S. Bridgewater \& J. F. Ribeiro (nom. nud.), Edinburgh Journal of Botany 60 (1): 122. 2003. Ratter et al. (2003), na listagem de plantas para o Cerrado brasileiro, citaram a ocorrência de Mezilaurus matogrossensis, afirmando que se tratava de um nome inédito. Os autores não realizaram descrição morfológica, diagnose em latim, não designaram tipos nomenclaturais, tão pouco deixaram claro que se tratava de uma espécie nova. Mezilaurus matogrossensis é, portanto, um nome não validamente publicado segundo o Código Internacional de Nomenclatura Botânica e caracterizado como nomen nudum (McNeill et al. 2007). 


\subsection{Revisão taxonômica de Clinostemon Kuhlm. \& A. Samp. (Lauraceae)}

\section{Tratamento taxonômico}

2. Clinostemon Kuhlm. \& A. Samp., Bol. Mus. Nac. Rio de Janeiro 4 (2): 57. 1928. Tipo: C. mahuba (A. Samp.) Kulhm. \& A. Samp.

Etimologia: Clinostemon é oriundo de clinos $=$ inclinar e stemon $=$ estame, em alusão aos estames encurvados (Kuhlmann \& Sampaio 1928).

2.1. Clinostemon mahuba (A. Samp.) Kuhlm. \& A. Samp., Bol. Mus. Nac. Rio de Janeiro 4 (2): 57. 1928. Acrodiclidium mahuba A. Samp., Comm. de Linhas Telegr. Estratégicas de MattoGrosso ao Amazonas 56 (anexo 5, parte X): 14. 1917. Licaria mahuba (A. Samp.) Kosterm., Rec. Trav. Bot. Neérl. 35: 123. 1938. Misanteca mahuba (A. Samp.) Lundell, Wrightia 4 (3): 100. 1969. Mezilaurus mahuba (A. Samp.) van der Werff, Ann. Missouri Bot. Gard. 74: 169. 1987. Tipo: Brasil. Pará, Gurupá, mata inundada do Rio Amazonas, Ducke s.n. (lectótipo, escolhido por Kostermans (1938c), MG; isolectótipos, B [destruído], INPA, K, MG, P, R, RB [desaparecido], U, US).

(Figura 31).

= Mezilaurus triunca van der Werff, Novon 4 (1): 68. 1994. Tipo: Peru. Loreto, Maynas, Iquitos, Allpahuayo, Estacion Experimental IIAP, Vásquez et al. 14372 (holótipo, MO; isótipos, AAU, AMAZ, HBG, NY, QRS). sin. nov.

Árvores até $35 \mathrm{~m}$ alt. Ritidoma escamoso, marrom-avermelhado a cinza. Crescimento rítmico apositivo nos ramos. Râmulos 7-14 mm diâm., cilíndricos a ligeiramente angulosos, ferrugíneos, velutinos a tomentosos, com cicatrizes de folhas senescentes, com lenticelas conspícuas próximas 
do ápice; catafilos ovados a lanceolados, (3-) 5-12 $\mathrm{mm}$ compr., ferrugíneos, velutinos a tomentosos. Folhas alternas, 23,1-60,8 × 7,9-20,6 cm. Lâminas obovadas a oblanceoladas, 1,84,1 vezes mais longas que largas, face abaxial pubescente a pubérula ou ligeiramente tomentosas, raramente subglabras ou glabras em partes da folha, todavia pubérulas na base, adaxial pubérula a subglabra, base aguda, fortemente assimétrica, ápice obtuso, arredondado ou emarginado, raro agudo, margem plana, pontuações glandulares na face abaxial, muitas vezes inconspícuas, face abaxial micropapilosa. Venação ligeiramente broquidódroma, 21-33 nervuras por lado, impressa à imersa na face adaxial, proeminente na abaxial; nervuras secundárias formando um ângulo de 50-90 com a primária, juntando com as suprajacentes em ângulos agudos, retos ou obtusos; terciárias percorrentes, oblíquas. Pecíolo (18-) 26-110,5 × 3,5-6 mm, representando 5-19\% da folha, plano, costado, pubescente a pubérulo, base ligeiramente dilatada. Inflorescências do tipo duplo ou triplo racemo (dibótrio ou tribótrio), axilares ou próximas do ápice dos ramos, 16-50 cm compr., do mesmo tamanho a menores que as folhas, raro maiores, pubescentes a pubérulas; ramos laterais $0,5-11 \mathrm{~cm}$ compr., ca. 50 (segunda ordem) ou 8-25 (terceira ordem) flores por ramo lateral; pedúnculos 3-10,6 cm compr.,. Brácteolas na base dos ramos laterais 1,25-2 × 0,5$0,75 \mathrm{~mm}$, na base dos ramos de terceira ordem $0,75-1 \times 0,4-0,5 \mathrm{~mm}$, três bractéolas na base dos pedicelos, uma maior $0,4-0,6 \times 0,3-0,4 \mathrm{~mm}$, duas menores, $0,3-0,5 \times 0,1-0,25 \mathrm{~mm}$ larg., triangulares, pubescentes, persistentes. Pedicelo 0,5-1,5 $\mathrm{mm}$ compr., pubescente a pubérulo, tricomas papilosos ou não papilosos. Flores 1,5-2,1 mm diâm., 1,6-2 mm compr., brancas a branco-amareladas ou verdes, globosas, ligeiramente elipsoides ou globosas, externamente pubescentes a pubérulas, tricomas papilosos e não papilosos. Tépalas desiguais, externas menores, externas $0,2-0,4 \times 0,2-0,5 \mathrm{~mm}$, internas $0,5-0,75 \times 0,5-1 \mathrm{~mm}$, ovadas, ápice agudo a obtuso, margem papilosa, internamente pubescentes, menores que o receptáculo, $1 /{ }_{3}-1 / 5$ do comprimento da flor. Estames livres, 1,2-1,75 $\times$ 0,75-1 $\mathrm{mm}$, exsertos na antese; anteras encurvadas, $0,5-0,75 \times 0,3-0,5 \mathrm{~mm}$, extrorsas, triangulares, glabras frontalmente ou pubérulas 
somente na base, pubescentes na face dorsal, não papilosas; filetes $0,5-1 \times 0,6-1 \mathrm{~mm}$, quadráticos ou retangulares, do mesmo tamanho a maiores que as anteras, pubescentes, um par de glândulas na base. Estaminódios 9, representando as séries I, II e IV do androceu, 0,6-0,8 mm compr., 0,1-0,2 mm larg., filiformes a subclaviformes, pubescentes. Pistilo 1,5-2 $\mathrm{mm}$ compr., glabro; ovário $0,6-0,8 \mathrm{~mm}$ compr., globoso a elipsoide; estilete $0,9-1,4 \mathrm{~mm}$ compr., exserto na antese. Receptáculo 1-1,75 mm compr., pubescente a pubérulo internamente. Frutos até $49 \times 23$ mm, elipsoides a obovoides, glabros ou ligeiramente pubescentes na base e ápice. Cúpulas 4-8 mm diâm., planas a pateliformes, externa e internamente pubérulas, diâmetros maiores que os pedicelos na frutificação. Pedicelo na frutificação 1,5-3,5 mm compr., liso, pubérulo a pubérulos, bractéolas persistentes.

Material Examinado: BRASIL. Amapá. Macapá, Rio Pedreira, próximo a loc. do Porto do Abacate, 27/04/1984, fr., B. V. Rabelo et al. 2632 (HAMAB); Mazagão, Rio Ajuruxi, 29/05/1984, fr., B. V. Rabelo \& J. Cardoso 2715 (HAMAB). Amazonas. Benjamin Constant, 22/10/1956, veg., E. M. Drees s.n. (INPA). Pará. Afuá, Rio Cajuúna, 14/11-04/12/1992, veg., U. N. Maciel et al. 2101 (MG); Ananindeua, margem direita do Rio Aurá, sítio do Sr. Evangelista, 14/04/2003, fr, J. Oliveira \& M. C. Nascimento 625 (MG); Barcarena, Ilha das onças, propriedade de Dona Alice Dumalakis, ca. 1 km da margem do Furo Santo Antônio, 12/1984, veg., A. B. Anderson \& C. S. Rosário 1453 (MG); Belém, 23/01/1949, fr., J. M. Pires 1488 (ALCB, NY); Parque do Museu Goeldi, 31/10/1994, fr., H. Lorenzi 1774 (HPL); Belém, Parque do Museu Goeldi (48 $28^{\prime} 36^{\prime \prime}$ 'W/1'27''12'’S), 18/11/2010, veg., F. M. Alves 528 (ESA); mata inundável perto do Rio Guamá, 04/06/1943, fl., A. Ducke 1234 (IAN, K, MG, NY, RB); Cametá, Ilha de Jubinha, 21/09/1986, fr, A. Gély \& A. Anderson 717 (MG); Cametá, Acima de Cametá Ilha maior, Jacarecaia, Rio Tocantins, 25/06/1980, fr., J. Revilla et al. 4520 (INPA); Guamá, lago Murutucu, 18/10/1923, fr., A. Ducke s.n. (RB, U [2 exsicatas]); forest across the Rio Guamá, 
08/11/1990, fr., H. van der Werff 11852 (MO); Delta do Amazonas, próximo Trapiche Hypolito, 24-25/08/1934, fl., B. A. Krukoff 5870 (BM, BR, K, U); Entre São Miguel e Acary, beira do rio Guamá, 31/10/1948, fr., Black \& Foster 48-3415 (ALCB); Gurupá, mata de várzea do Amazonas, 30/12/1916, fruto, A. Ducke s.n. (MG); Ilha do Pará, canal norte do Rio Amazonas, S de Macapá, 07/10/1983, fl., fr., S. Mori et al. 16510 (HAMAB, K, MG); Melgaço, Base física da Floresta Nacional de Caixuanã, a Beira do Ramal da Torre, 22/05/1991, fr, J. Oliveira et al. 78 (MG). PERU. Amazonas. Bagua Province, Distrito Imaza, Yamayakat, 09/11/1996, fr., $R$. Vásquez et al. 21642 (MO); Región Nororiental del Marañon, Cominudad de Yamayakat, Rio Marañon, 16/07/1994, fl., R. Vásquez et al. 18724 (MO); Condorcanqui Province, Distrito El Cenepa, Comunidad de San Antonio, Rio Cenepa, 22/06/11997, fl., R. Vásquez et al. 24115 (MO). Huánuco, Prov. Puerto Inca, Dtto. Yuyapichis - Selva Central, Dantas (7502’S $\left./ 9^{\circ} 40^{\prime} \mathrm{W}\right)$, 16-31/12/1989, bot., Flores \& Tello 310 (G). Loreto. Maynas Province, Allpahuayo, 26 km along road Iquitos-Nauto, 23/08/1998, fr., van der Werff et al. 10227 (G, HBG, K, MO, U [2 exsicatas]); Santa Maria de Nanay, Quebrada Yarina, 22/05/1989, fr., R. Vásques \& N. Jaramillo 12231 (HBG, U); Allpahuayo, Estación Experimental del Instituto de Investigaciones de la Amazonía Peruana (IIAP), 12/09/1990, fl., R. Vásques et al. 14372 (G, HBG, MO); Iquitos, Estación Experimental IIAP, Alpahuayo, 21 km ao S de Iquitos, 20/09/1990, fl., J. J. Pipoly et al. 12230 (U). Ucayali. Prov. Coronel Portilho, Distr. Calleria, Cuenca del Rio Utiquinia, Quebrada Espjoyacu, afluente de la quebrada Manuela (73 $53^{\prime} 61^{\prime}$ 'S $\left./ 07^{\circ} 56^{\prime} 67^{\prime \prime} \mathrm{W}\right), 26 / 08 / 2003$, bot., $J$. G. Graham 2794 (G, MO).

Distribuição e ecologia: Clinostemon mahuba possui registro de ocorrência para o Brasil e Peru. No Brasil, a espécie é característica da porção oriental da Amazônia, nos estados do Pará e Amapá e extremo oeste do estado do Amazonas. No Peru C. mahuba é conhecida para a região norte e nordeste do país nos estados do Amazonas e Loreto (Figura 32). Clinostemon mahuba 
ocorre na sub-região Amazônica, províncias do Amapá, Madeira, Pará, Napo e Varzea (Figura 1). No Brasil, a espécie é característica da floresta inundada sazonalmente ou "mata de várzea" do rio Amazonas e na floresta de terra firme em regiões próximas à sua foz. No Peru, C. mahuba ocorre na floresta de terra firme e floresta ciliar. Coletada em solos argilosos ou lateríticos, do nível do mar até $30 \mathrm{~m}$ de altitude no Brasil ou entre 120 e $480 \mathrm{~m}$ no Peru.

Fenologia: Coletada com flores em junho a outubro, frutos em janeiro, abril a junho, agosto, setembro, novembro a dezembro.

Etimologia: O epíteto mahuba é uma referência ao nome popular "mahuba".

Status de conservação: Clinostemon mahuba apresenta distribuição geográfica ampla, com grande quantidade de espécimes coletados, inclusive recentemente. Portanto, a espécie deve ser considerada como "Menor Preocupação" (LC) nos critérios da IUCN (2001).

Nome popular: mahuba, maúba, mauba-da-vermelha.

Importância econômica: Clinostemon mahuba apresenta madeira considerada "de lei", boa para contruções de embarcações e para lenha. Segundo Sampaio (1917) a madeira da espécie é utilizada na Amazônia para construção comum.

Clinostemon mahuba é caracterizada por possuir folhas grandes $23,1-60,4 \times 9,4-20,6 \mathrm{~cm}$, lâminas foliares obovadas a oblanceoladas, inflorescências do tipo duplo ou triplo racemo (dibótrio ou tribótrio), $21-50 \mathrm{~cm}$, três bractéolas na base dos pedicelos, flores pubescentes a pubérulas, anteras encurvados, um par de glândulas nos filetes, nove estaminódios, representando as séries I, II e IV do androceu e fruto com cúpula pateliforme a plana com tépalas persistentes

A espécie pode ser confundida com Mezilaurus duckei ou M. thoroflora por compartilharem folhas grandes, flores com três estames férteis, representando a III série do androceu, anteras biloceladas, nove estaminódios, séries I, II e IV do androceu e fruto com cúpula 
pateliforme a plana com tépalas persistentes. Todavia, Mezilaurus thoroflora e M. duckei possuem anteras eretas e ausência de glândulas nos filetes.

Ao descrever Mezilaurus triunca, van der Werff (1994) relatou que a espécie diferenciase de Clinostemon mahuba (M. mahuba) por seus longos pecíolos (4-9 $\mathrm{cm}$ de comprimento em M. triunca e 2-3 cm em M. mahuba), folhas glabras na face abaxial (M. mahuba com indumento curto, tricomas eretos) e distribuição (M. mahuba é restrita para a floresta de várzea no Pará e Amapá, Brasil; M. triunca ocorre na floresta de terra firme próximo de Iquitos, Peru). Já Sampaio (1917) ao descrever Clinostemon mahuba (Acrodiclidium mahuba), relatou que a espécie possuía pecíolos de 2,5-3,5 cm.

Materiais da espécie coletados no Brasil, próximos a foz do rio Amazonas, apresentam pecíolos que podem variar de 1,8 a 8,5 cm compr. Enquanto Mori et al. 16510, Ducke s.n. (R 61241) (isolectótipo de Acrodiclidium mahuba Samp.), Krukoff 5870 (BR, BM, K, U) e van der Werff 11852 (MO 3799051) apresentam pecíolos com tamanhos inferiores a $3 \mathrm{~cm}$ compr., Ducke s.n. depositadas no MG (16692) (lectótipo de Acrodiclidium mahuba Samp.) e Mori et al. 16510 do HAMAB (4173) possuem pecíolos com tamanhos superiores a $5 \mathrm{~cm}$ compr. Em adição, Maciel et al. 2101, coletado no município de Afuá, Rio Cajuúna (MG 145950) apresenta pecíolo com 8,5 cm compr. Já o espécime Drees s.n. (INPA 5610), coletado em Benjamim Constant, extremo oeste do estado do Amazonas no Brasil, próximo a fronteira com o Peru, apresenta pecíolos com até $3 \mathrm{~cm}$ compr.

Por outro lado, coletas oriundas do Peru apresentam pecíolos variando de 2,5 até 10,5 cm compr. Tello 1930 possui pecíolos com no máximo 2,6 cm compr., enquanto Vásquez et al. 18724 (MO 5297777), parátipo de M. triunca, apresenta pecíolos de 3,9 cm compr. O holótipo, Vásquez et al. 14372, apresenta pecíolos de $3 \mathrm{~cm}$ compr., enquanto no isótipo do herbário HBG (509890) estas estruturas podem alcançar no máximo 6 cm compr. Já Vásquez et al. 24115 (MO 
4958778) e Vásquez et al. 21642 (MO 4900703) apresentam pecíolos com tamanhos superiores a $10 \mathrm{~cm}$ compr.

Com relação ao indumento das lâminas foliares, os espécimes coletados tanto no Brasil, quanto no Peru, podem apresentar lâminas com face abaxial pubescentes a pubérulas. No Brasil, todos os espécimes coletados apresentam lâminas foliares pubescentes a pubérulas. No Peru, Tello 1930, possui lâminas foliares pubescentes, enquanto Vásquez et al. 14372 (HBG 509890, MO 4345581, G 461976), Vásquez et al. 21642 (MO 4900703), Vásquez et al. 18724 (MO 5297777) e Vásquez et al. 24115 (MO 4958778) compartilham lâminas foliares pubérulas. No entanto, as coletas de Pipoly et al. 12230 (U) e Vásques \& Jaramillo 12231 (HBG, U) apresentam regiões das lâminas foliares glabras a subglabras ou pubérulas na base.

Portanto, as características citadas acima fazem parte da variação da espécie e não há descontinuidade com relação ao tamanho do pecíolo ou ao indumento das lâminas foliares. Em adição, após a análise de todas as características citadas na descrição, nenhuma se mostrou descontínua para que os materiais examinados fossem colocados como duas espécies. Por essa razão, nós sinonimizamos Mezilaurus triunca em Clinostemon mahuba.

Ao descrever Acrodiclidium mahuba, Sampaio (1917) citou um síntipo, proveniente de "Pará: Gurupá, in sylvis inundatis flum. Amazonas: Dr. Adolpho Ducke". O autor não referiu a instituição de depósito deste espécime, porém, assinou o protólogo como representante do Museu Nacional do Rio de Janeiro e foi professor de botânica da instituição (Stafleu \& Cowan 1985). Posteriormente, Kostermans (1938c) elegeu (inferencialmente) o espécime do herbário MG (Museu Paraense Emílio Goeldi, Belém, Brasil) como lectótipo de Acrodiclidium mahuba.

Na exsicata depositada no herbário do Museu Nacional (R), estão os desenhos originais com detalhes das flores e frutos que Sampaio (1917) utilizou no protólogo. O autor utilizou informações no protólogo exatamente como as encontradas na exsicata do Museu Nacional, inclusive detalhes de fenologia, ausentes nos exemplares do INPA, K, MG, P, U e US. Além do 
mais, Sampaio (1917) fotografou a exsicata encontrada no Museu Nacional e colocou como estampa no protólogo. Essas informações indicaram claramente que o exemplar utilizado para descrever Acrodiclidium mahuba foi o depositado no herbário do Museu Nacional do Rio de Janeiro (R 61241). Porém, Kostermans (1938c) poderia ter lectotipificado qualquer duplicata do material utilizado por Sampaio (1917), mesmo que este não tivesse sido visto pelo autor ou citado no protólogo.

Segundo a Nota 2 do Art. 9.2 do Código Internacional de Nomenclatura Botânica de Viena "Para os propósitos desse código, o material original compreende: $(a)$ os espécimes a as ilustrações (tanto publicadas quanto não publicadas e concomitantes com o protólogo) sobre os quais pode se demonstrar que foi baseada a discrição ou diagnose que validou o nome; $(b)$ o holótipo e esses espécimes que, mesmo que não tenham sido vistos pelo autor da discrição ou diagnose que validou o nome, foram indicados como tipos (síntipos ou parátipos) do nome no ato da publicação válida; e $(c)$ os isótipos e isossíntipos do nome independentemente se tais espécimes foram ou não vistos pelo autor que validou a discrição ou diagnose ou pelo autor do nome" (McNeill et al. 2007). Por essa razão, nós desconsideramos a citação de qualquer outro espécime como holótipo de Acrodiclidium mahuba e aceitamos a lectotipificação (inferencial) do exemplar depositado no herbário MG, realizada por Kostermans (1938c).

O espécime Flores \& Tello 310, depositado no herbário de Genebra (G), é colocado aqui com exitação. O exemplar pode representar uma nova espécie de Clinostemon. A possível nova espécie foi coletada no Peru, Dpto de Huánuco, Prov. Puerto Inca, Dtto. Yuyapichis, na Selva Central, Dantas. O espécime apresenta lâminas estreito-elípticas ou oblongas, 3,6-5 vezes mais longas que largas, pecíolos $2-3,5 \mathrm{~cm}$ comprimento, ca. $16 \%$ da folha, ápice foliar retuso e inflorescência curta. Todavia, a inflorescência só possuía botões jovens, não sendo suficiente para essa conclusão. 


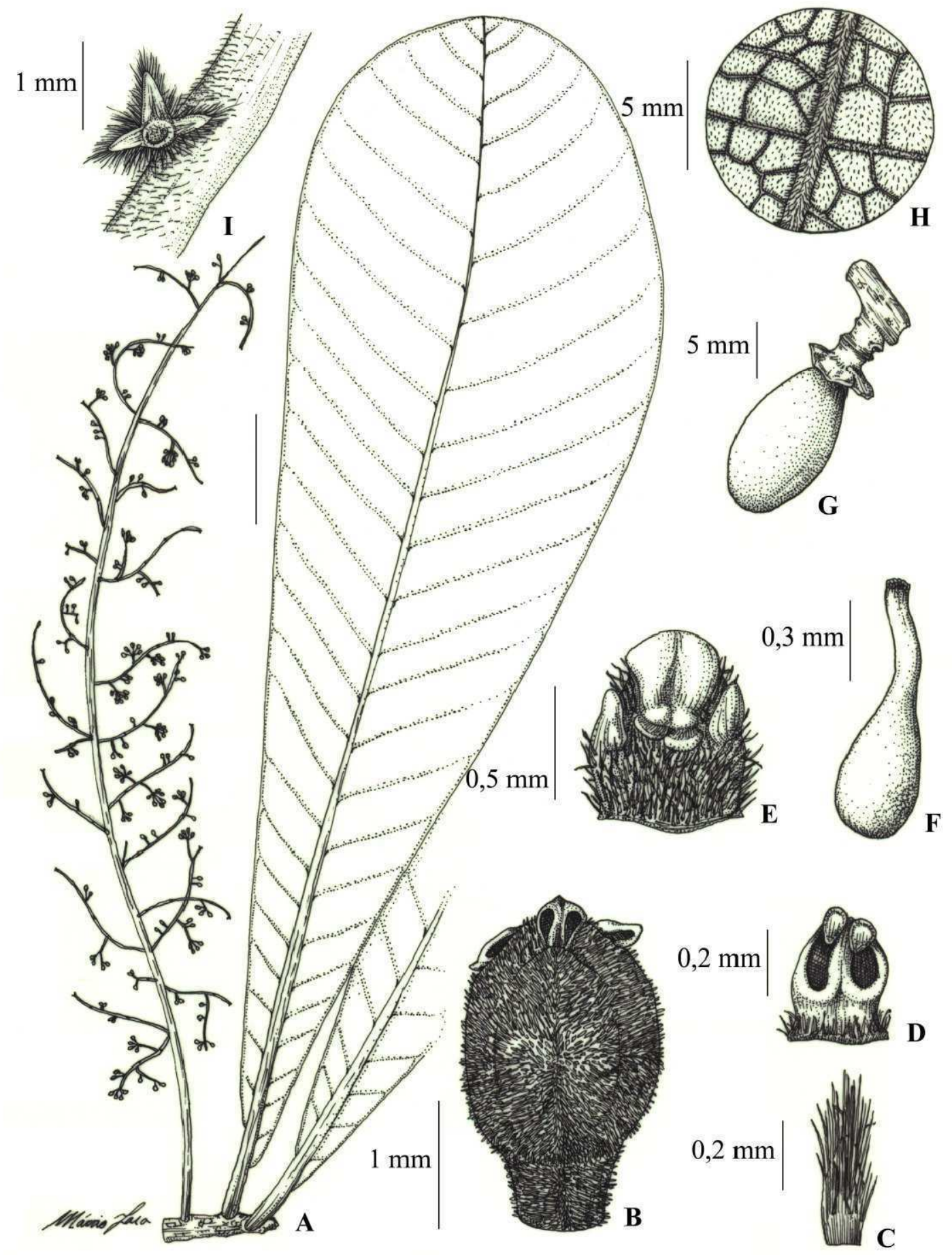

Figura 31: Ilustração de Clinostemon mahuba. A: ramo com flores; B: flor; C: estaminódio; D: antera; E: estame; F: pistilo; G: fruto; H: detalhe do indumento na face abaxial da lâmina foliar; I: detalhe das três bractéolas da base dos pedicelos. 


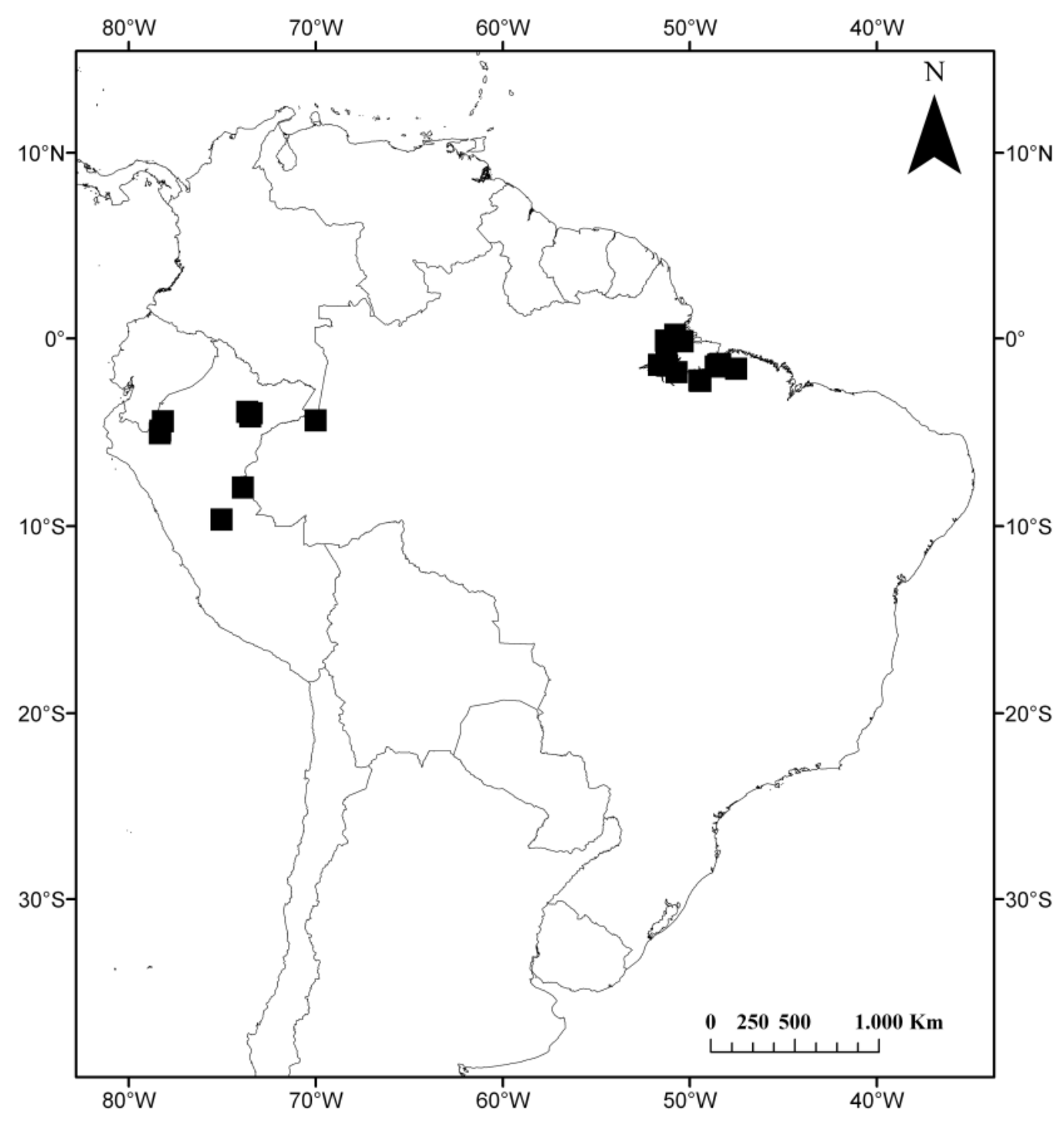

Figura 32: Mapa de distribuição geográfica de Clinostemon mahuba (quadrados). 


\section{Nomes excluídos}

Clinostemon maguireanum (C. K. Allen) Kurz $\equiv$ Mezilaurus thoroflora van der Werff

\subsection{Considerações Morfológicas}

\section{Hábito e Ritidoma}

Espécies de Mezilaurus são geralmente árvores ou arvoretas (Figura 33, A e B), desde 1,8 $\mathrm{m}$ até árvores de dossel chegando a $45 \mathrm{~m}$, entretanto, árvores de 8-20 m são mais comuns e raramente desenvolvem-se como arbustos. Mezilaurus itauba atinge de 2 a $45 \mathrm{~m}$, com árvores menores em áreas de Cerrado e na Caatinga Amazônica. Mezilaurus crassiramea quando coletada na região do Brasil central não ultrapassou 10 m, entretanto, na Floresta Atlântica ou na região amazônica pode chegar até $35 \mathrm{~m}$. Mezilaurus duckei, M. introrsa, M. navalium e M. thoroflora podem também alcançar mais de $30 \mathrm{~m}$ de altura.

A maioria das espécies tem uma casca relativamente fina, com exceção das encontradas na região do Cerrado brasileiro. A presença de lenticelas no tronco, muito frequente nas espécies de Lauraceae neotropicais, não é conspícua em Mezilaurus. O ritidoma pode ser rugoso, escamoso, estriado, fissurado ou em placas. A cor do ritidoma pode variar de avermelhado a marrom-avermelhado, acinzentado, bege ou verde nas espécies coletadas na Amazônia e Floresta Atlântica ou acinzentados ou marrom nas coletadas na floresta estacional ou no Cerrado (Figuras $33[\mathrm{C}$ e D] e 34).

Clinostemon é representado por árvores com até $35 \mathrm{~m}$ alt. e ritidoma escamoso, marromavermelhado a cinza (Figura 35). 

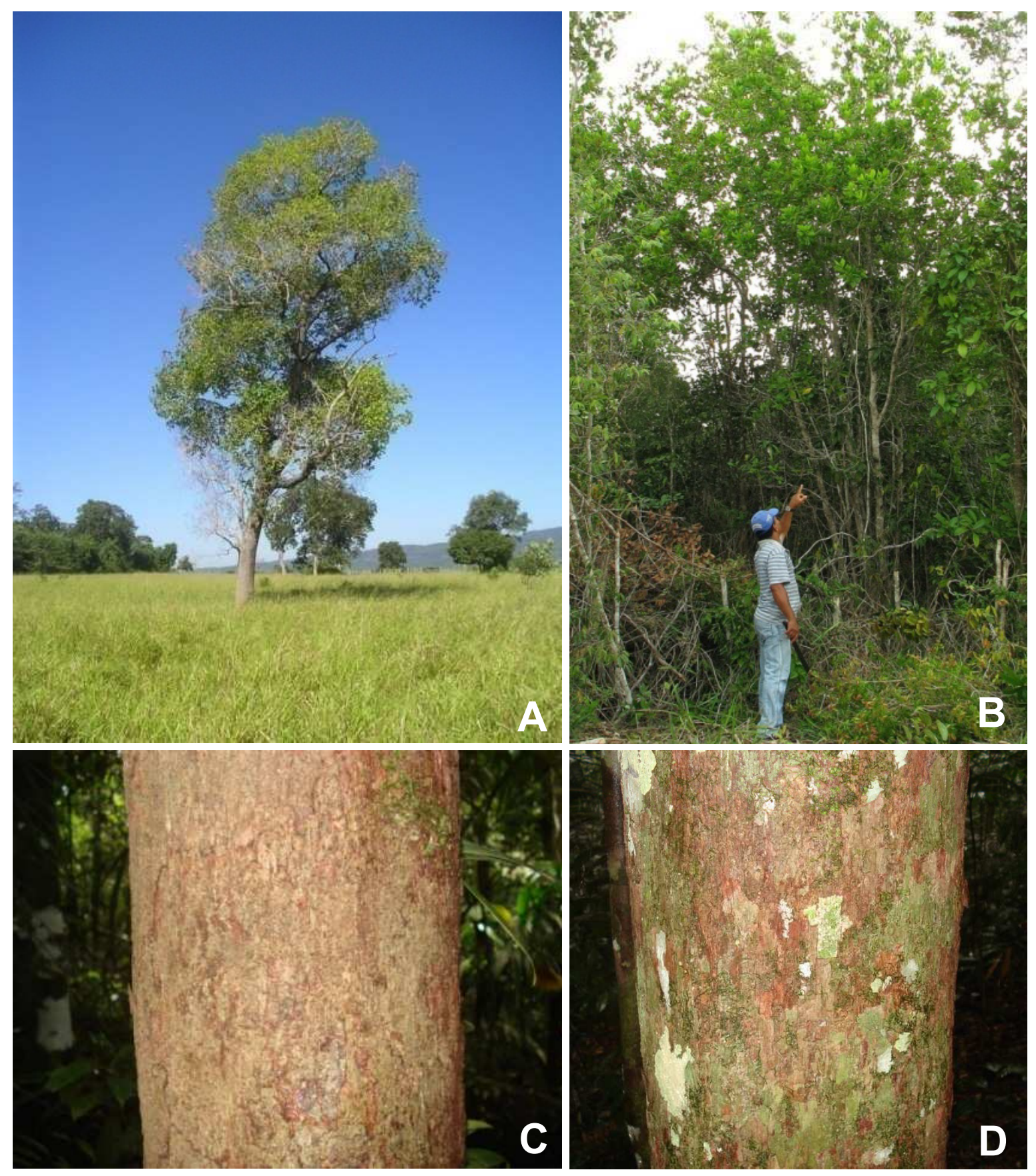

Figura 33: árvores e troncos de Mezilaurus. A: árvore de Mezilaurus vanderwerffii. B: árvore de $M$. revolutifolia. C. tronco de M. itauba. E: tronco de M. duckei (Foto B: Alex Popovkin). 

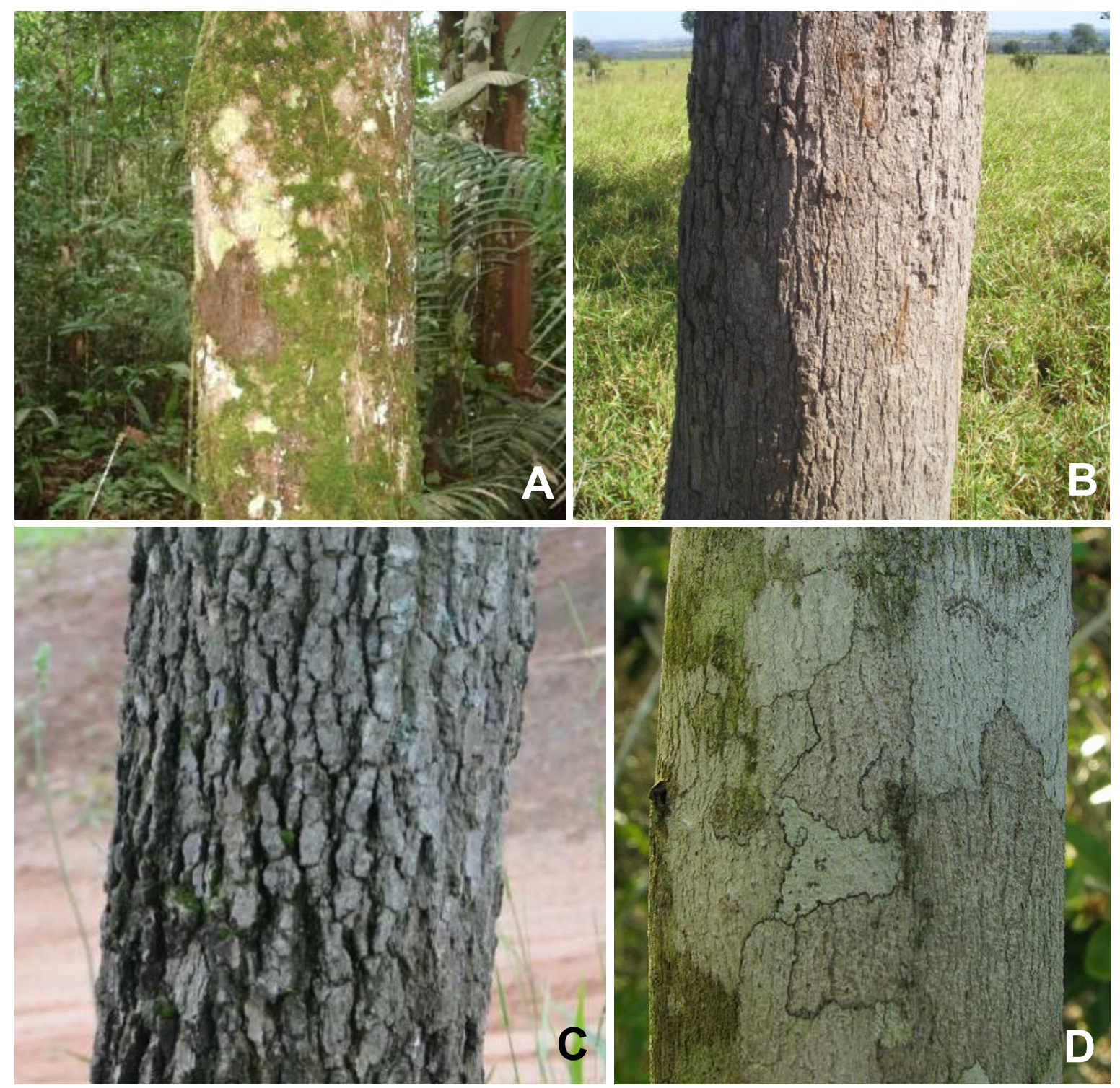

Figura 34: Troncos de Mezilaurus. A: M. synandra; B: $M$. vanderwerffii; C: $M$. crassiramea; D: M. revolutifolia (Foto D: Alex Popovkin). 

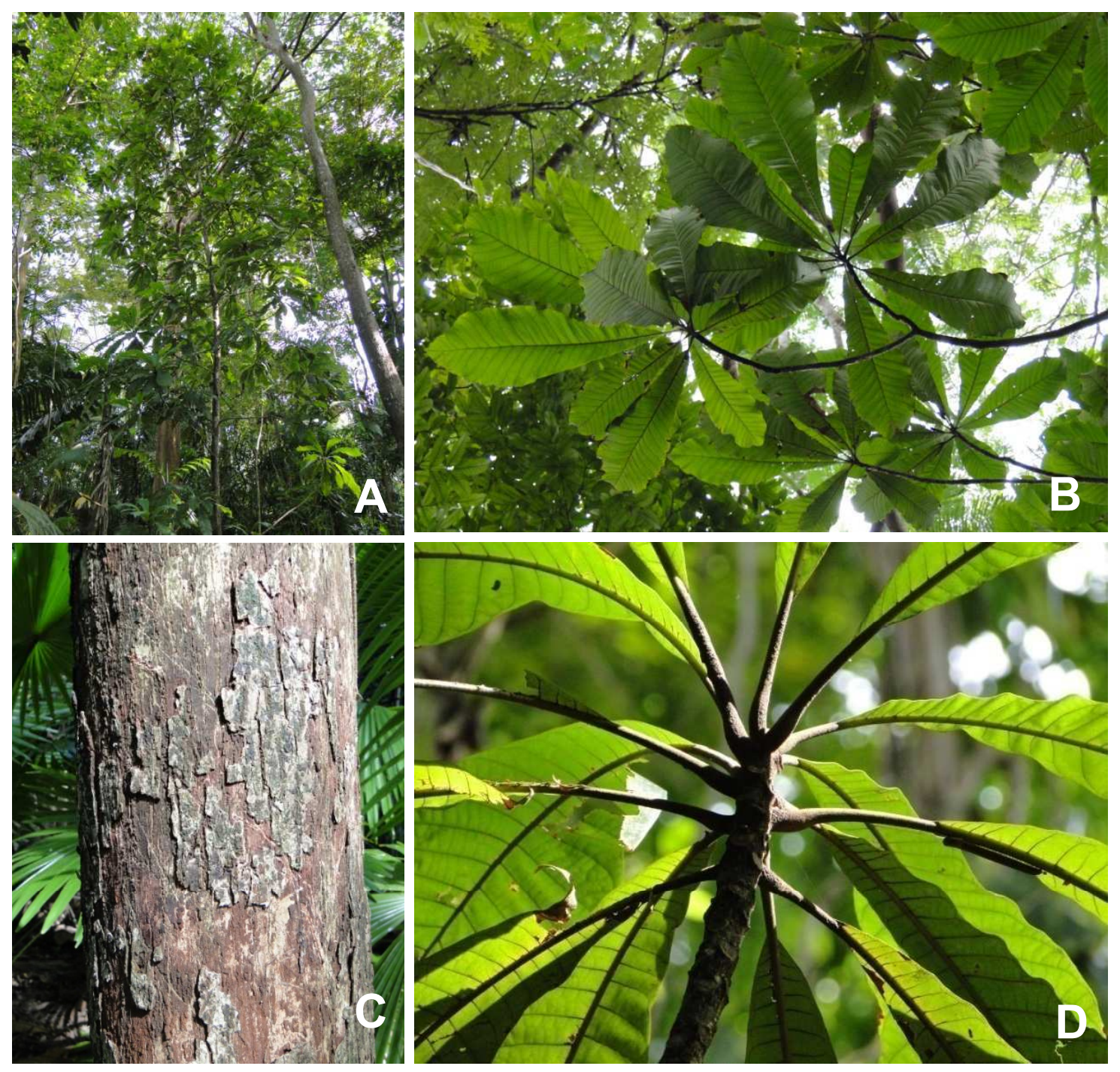

Figura 35: Clinostemon mahuba. A: árvore; B: ramo; C: tronco; D: detalhe do ápice do ramo. 


\section{Ramos e Râmulos}

Crescimento rítmico apositivo nos ramos ocorre em todas as espécies de Mezilaurus e Clinostemon, nas quais, segundo Vicentini et al. (1999), há um prolongamento inicial dos ramos sem a produção de folhas, que estão agrupadas no ápice das unidades de crescimento; o meristema terminal é substituído por um meristema axilar que continua o crescimento do ramo, enquanto o primeiro forma um ramo curto onde ficam agrupadas as folhas. Van der Werff (1987) caracterizou esse tipo de crescimento como "shoot-short-shoot". Essa conformidade dos ramos se assemelha às encontradas em espécies de Anacardium L. (Anacardiaceae), Terminalia L. (Combretaceae) e Pouteria Aubl. (Sapotaceae), com as quais Mezilaurus é confundido com frequência (Figura 35 [B e D] e 36).

Os râmulos são cilíndricos ou, raramente angulosos, geralmente com 3-7 mm diâm. Em Mezilaurus microphylla os râmulos podem atingir no máximo $2 \mathrm{~mm}$ diâm., enquanto estes podem alcançar até $11 \mathrm{~mm}$ diâm. em M. duckei. Cicatrizes das folhas senescentes (Figura 35 [C] e 36 [C]) e lenticelas próximas do ápice dos ramos são bastante conspícuas em Clinostemon e Mezilaurus. O indumento dos râmulos varia de pubérulo a pubescente, tomentoso, seríceo ou raramente glabro ( $M$. caatingae). Os catafilos são ovados a lanceolados, podendo atingir no máximo 3,5 mm diâm. em $M$. synandra ou alcançar até $11 \mathrm{~mm}$ diâm. em $M$. duckei. Os catafilos podem ser tomentosos, pubescentes ou seríceos, de cor creme, amarelo a dourado ou ferrugíneo.

\section{Folhas}

As folhas de Clinostemon e Mezilaurus são congestas no ápice dos ramos, produto de seu crescimento rítmico apositivo. Em Clinostemon as folhas são sempre alternas e grandes, 23,160,8 × 7,9-20,6 cm, quando comparado com a maioria das espécies de Mezilaurus. 

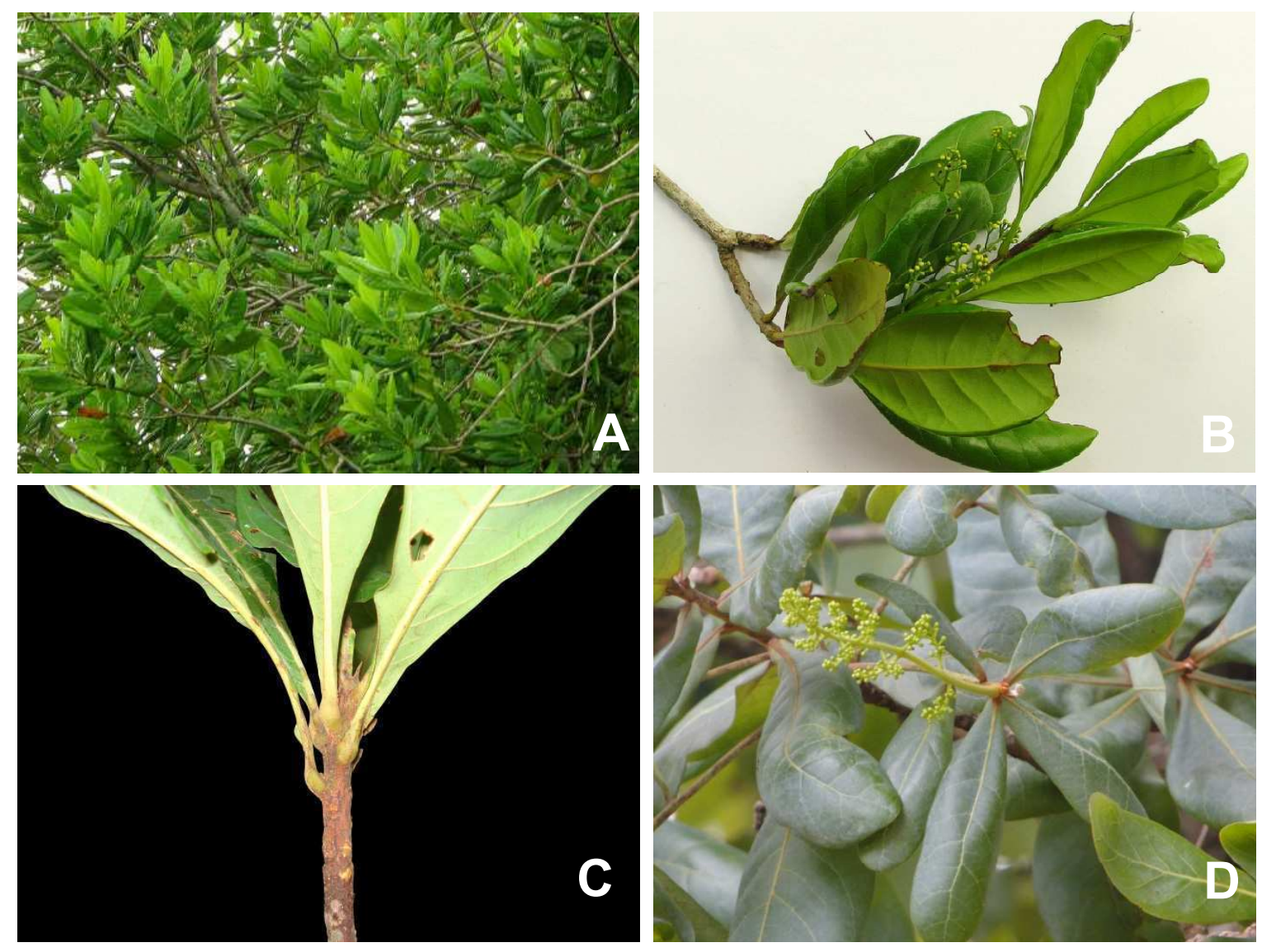

Figura 36: Ramos de Mezilaurus. A-B: M. revolutifolia (Fotos: Alex Popovkin). C: folhas congestas na extremidade dos ramos de M. duckei (Alves 524). D: ramo florífero de $M$. crassiramea (Alves 530). 
Clinostemon mahuba apresenta lâminas foliares obovadas a oblanceoladas. Em Mezilaurus as folhas são alternas, raramente opostas a subopostas ou subverticiladas. Em $M$. sprucei podem ser observadas todas as formas intermediárias entre folhas alternas e opostas, enquanto alguns ramos de $M$. revolutifolia possuem folhas subverticiladas. As folhas atingem no máximo 9,6 × $3 \mathrm{~cm}$ em $M$. microphylla, enquanto em M. thoroflora podem alcançar até $66,7 \times$ 17,3 cm. As lâminas foliares em Mezilaurus podem ser elípticas a obovadas, oblanceoladas ou raramente ovadas ou lanceoladas.

Clinostemon apresenta lâminas foliares na face abaxial pubescentes a pubérulas ou ligeiramente tomentosas (Figura 37, A e B), enquanto na maioria das espécies de Mezilaurus, as lâminas foliares são glabras ou subglabras. $\mathrm{Na}$ face abaxial das lâminas foliares, Mezilaurus crassiramea possui indumento hirsuto, viloso a lanoso enquanto em $M$. duckei e $M$. thoroflora é pubérulo (Figura 37, C-D).

O ápice das lâminas foliares é usualmente agudo, obtuso ou arredondado, raramente retuso, emarginado ou cuspidado; a base é cuneada, decorrente ou aguda, menos frequentemente subcordada M. subcordata. Em Clinostemon a base da lâmina foliar é fortemente assimétrica, enquanto nas espécies de Mezilaurus são simétricas ou ligeiramente assimétricas. A margem geralmente é plana ou ligeiramente revoluta na base, contudo, em $M$. crassiramea e $M$. revolutifolia a folha pode ser inteiramente revoluta. Pontuações glandulares nas lâminas foliares podem estar presentes ou ausentes, sendo geralmente mais conspícuas na face abaxial.

A venação foliar fornece poucas características diagnósticas para Mezilaurus, uma vez que geralmente é broquidódromas a ligeiramente broquidódromas, bem definida no ápice e base, no entanto, indistinguível na região mediana da lâmina foliar. A venação pode ser impressa ou proeminente na face adaxial e proeminente na abaxial. 

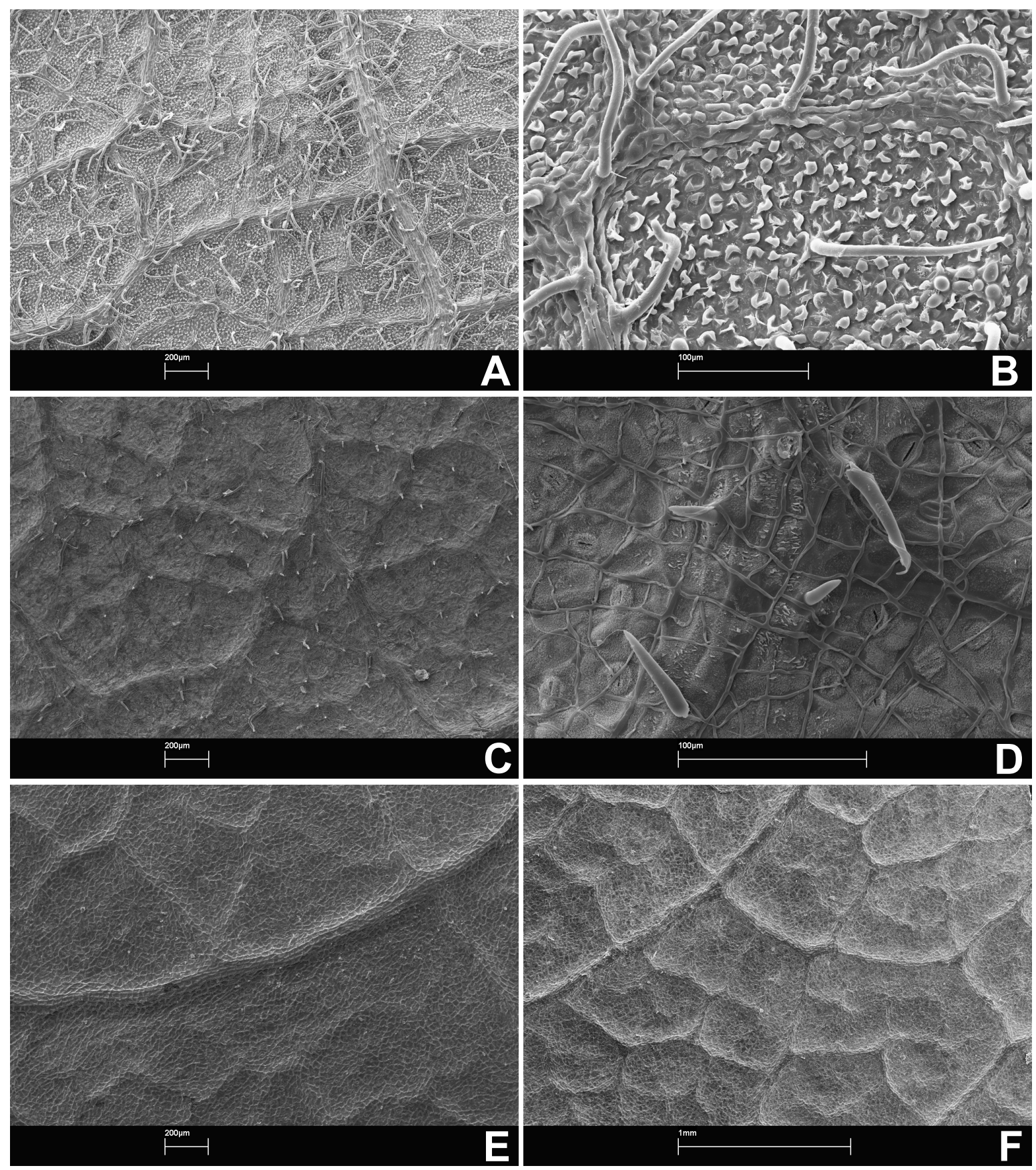

Figura 37: Indumento da face abaxial da lâmina foliar de Clinostemon e Mezilaurus. AB: C. mahuba (Krukoff 5870); C: M. duckei (Alves 524); D: detalhe dos tricomas de $M$. duckei (Alves 524); E: M. glabriantha (Barbosa \& Alves 1012); F: M. subcordata (Ferreira et al. 8772). 
Em M. caatingae, a venação é imersa em ambas as faces. As nervuras secundárias não ultrapassam 12 por lado em M. microphylla e podem chegar a 28 ou mais em M. duckei, M. navalium e M. thoroflora. Em Clinostemon mahuba pode ocorrer 21-33 nervuras por lado nas lâminas foliares.

Os pecíolos não ultrapassam $12 \mathrm{~mm}$ compr. em M. caatingae, M. microphylla, $M$. thoroflora e $M$. vanderwerffii, podendo chegar até 62 e $75 \mathrm{~mm}$ compr. em $M$. synandra e $M$. subcordata, respectivamente. Os pecíolos representam no máximo $10 \%$ da folha em $M$. caatingae, M. crassiramea, M. decurrens, M. duckei, M. thoroflora e M. vanderwerffii. Em M. thoroflora e na maioria das coletas de M. crassiramea, os pecíolos atingiram no máximo $2 \%$ do tamanho das folhas. Por outro lado, em M. itauba, M. subcordata e M. synandra os pecíolos podem ultrapassar $25 \%$ do comprimento da folha. Os pecíolos no gênero são planos a ligeiramente canaliculados, pubescentes a pubérulos ou lanosos, raramente glabros. Clinostemon, porém, apresenta pecíolos costados, podendo alcançar até 110,5 mm compr., representando 5$19 \%$ da folha, pubescentes a pubérulos.

Baseado em características vegetativas, Clinostemon e Mezilaurus podem ser separados, baseado na presença do primeiro gênero de folhas fortemente assimétricas na base Dentre as características vegetativas, as mais importantes para separação das espécies de Mezilaurus são: indumento dos ramos; tamanho, forma e indumento das folhas, especialmente na face abaxial da lâmina foliar, tamanho do pecíolo, sua proporção em relação ao tamanho do limbo e indumento. Para separação de

\section{Inflorescência}

A inflorescência em Clinostemon e Mezilaurus é caracterizada por um sistema politélico (indeterminado), com o eixo principal da inflorescência não terminando com uma flor no ápice, 
todavia, com flores laterais (Weberling 1985a, b; Weberling 1989). Em Clinostemon as inflorescências podem variar de racemos duplos (dibótrios) ou triplos (tribótrios) com ramos terminais não umbeliformes. A inflorescência de Mezilaurus é um duplo racemo (dibótrio), com ramos laterais não umbeliformes em $M$. crassiramea, $M$. duckei e $M$. thoroflora ou ramos laterais umbeliformes nas outras espécies (Figura 38). Em M. itauba, M. subcordata e M. sprucei a inflorescência pode apresentar ramos laterais mais laxos, mas sempre com flores ocorrendo a partir do terço superior do ramo lateral até o ápice, associado com flores totalmente congestas na extremidade de outros ramos laterais.

O tamanho das inflorescências atinge no máximo $10 \mathrm{~cm}$ compr. em M. glabriantha, $M$. microphylla, M. navalium, M. revolutifolia e $M$. vanderwerffii ou exceder os $45 \mathrm{~cm}$ em M. duckei e M. thoroflora. O indumento varia de viloso, pubescente, pubérulo a curtamente pubérulo, porém, glabro a subglabro em M. microphylla.

As características da inflorescência são extremamente úteis para o reconhecimento das espécies quando combinadas com o tipo de indumento das lâminas foliares na face abaxial e a presença de bractéolas persistentes ou decíduas.

As bractéolas podem ser decíduas ou persistentes, pubescentes, pubérulas ou glabras a subglabras. Quando a inflorescência é um duplo racemo, as bractéolas são consistentemente persistentes, ao passo que em inflorescências em racemo com flores agrupadas no ápice dos ramos laterais, elas são decíduas. Em $M$. duckei e M. thoroflora as bractéolas sempre persistem até mesmo na fase de frutificação, podendo esta característica ocorrer eventualmente em $M$. crassiramea.

Os pedicelos podem atingir no máximo $1 \mathrm{~mm}$ em $M$. introrsa e são sempre menores que as flores nessa espécie. Em M. sprucei, os pedicelos podem alcançar $23 \mathrm{~mm}$ e ser 15 vezes maiores que o comprimento das flores. O indumento do pedicelo pode variar de pubescente, pubérulo a glabro, com tricomas papilosos apenas em $M$. crassiramea. 

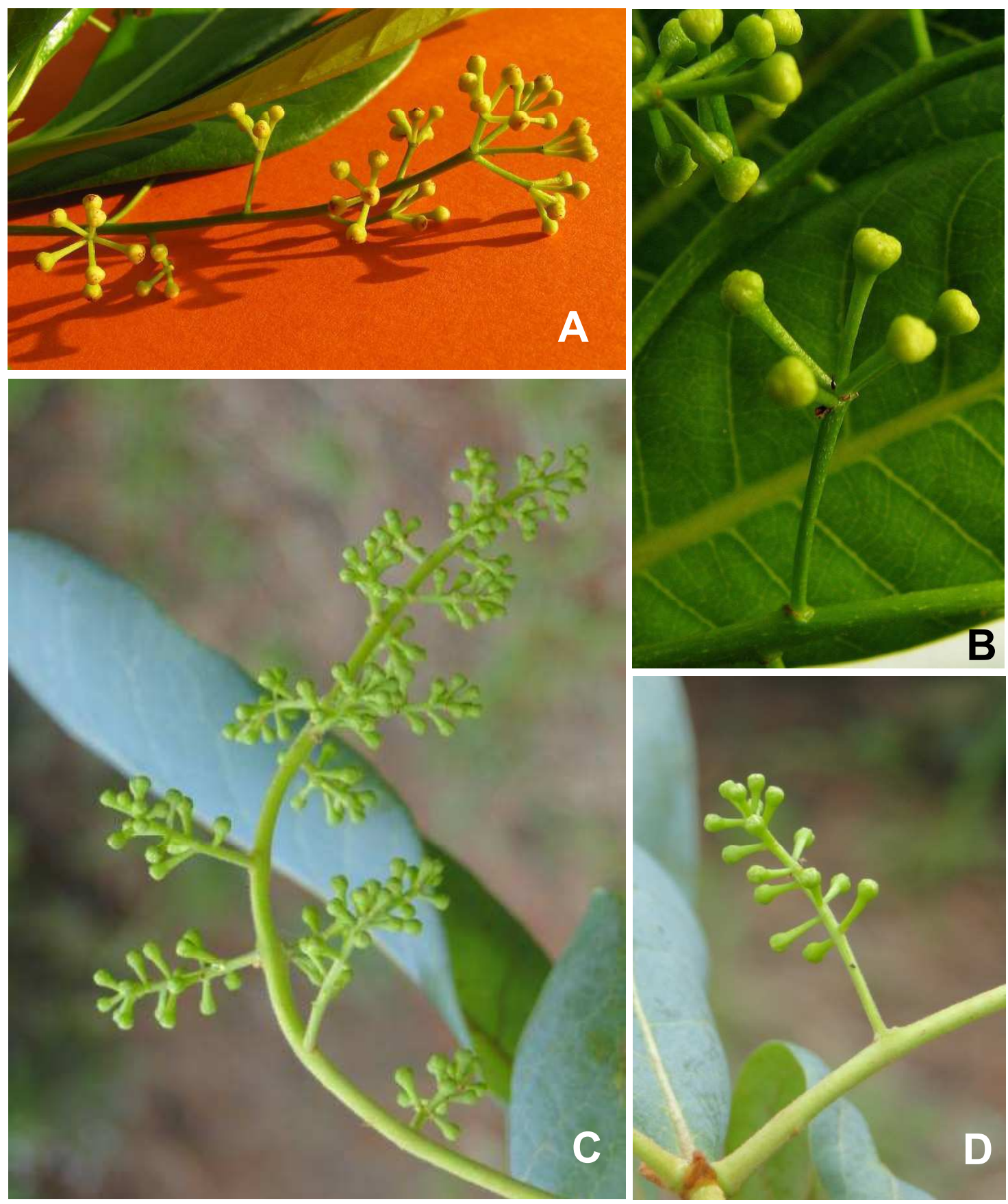

Figura 38: Inflorescências de Mezilaurus. A: duplo racemo (dibótrio) com ramos laterais umbeliformes de $M$. revolutifolia; B. detalhe de um ramo lateral da inflorescência de $M$. revolutifolia (Fotos: Alex Popovkin); C. duplo racemo (dibótrio) com ramos laterais não umbeliformes de $M$. crassiramea; D. detalhe de um ramo lateral da inflorescência de $M$. crassiramea (Alves 530). 
Clinostemon e Mezilaurus caatingae possuem três bractéolas na base de cada pedicelo, dispostas de forma que duas ficam opostas e uma perpendicular. Outras espécies de Mezilaurus apresentam somente uma bractéola na base dos pedicelos.

\section{Flores}

As flores de Mezilaurus podendo atingir $1 \mathrm{~mm}$ diâm. em $M$. duckei ou alcançar no máximo 2,5 mm diâm. em M. crassiramea. Em Clinostemon as flores alcançam 1,5-2,1 mm diâm. O tamanho das flores apesar de ser utilizado na taxonomia da família (e.g. Rohwer 1993b; van der Werff 1993; Madriñán 2004b), em Mezilaurus não se mostrou tão útil, por haver diferenças mínimas e sobreposição em quase todas as espécies.

As flores de Clinostemon e Mezilaurus compartilham a presença de três estames férteis, representando a serie III do androceu e anteras biloceladas. As flores dos gêneros são trímeras, bissexuadas, amarelas, verde-amareladas ou creme, elipsóides, globosas ou depressas (Figura 39, A-D). As tépalas estão dispostas em duas séries de três, ovadas, iguais ou desiguais, quando desiguais as externas são geralmente menores, contudo, em M. synandra as tépalas externas são maiores que as internas. As tépalas podem ser do mesmo tamanho ou ligeiramente maiores que o receptáculo, ca. $1 / 2$ do comprimento da flor ou menores que o receptáculo, atingindo $1 / 3^{-1 / 5}$ do comprimento da flor (Figura 39, B e D).

O indumento pode ser pubescente, pubérulo a glabro, interna ou externamente (Figuras 39 [A-F] e $40 \mathrm{~A}-\mathrm{B}$ ), com tricomas não papilosos na maioria das espécies, podendo ser papilosos em M. crassiramea (Figura 40, D).

Clinostemon e Mezilaurus apresentam os três estames férteis, representando a III série do androceu, de formas e tamanhos variados com quase indistinta diferenciação entre filete e antera (Figura 41). 

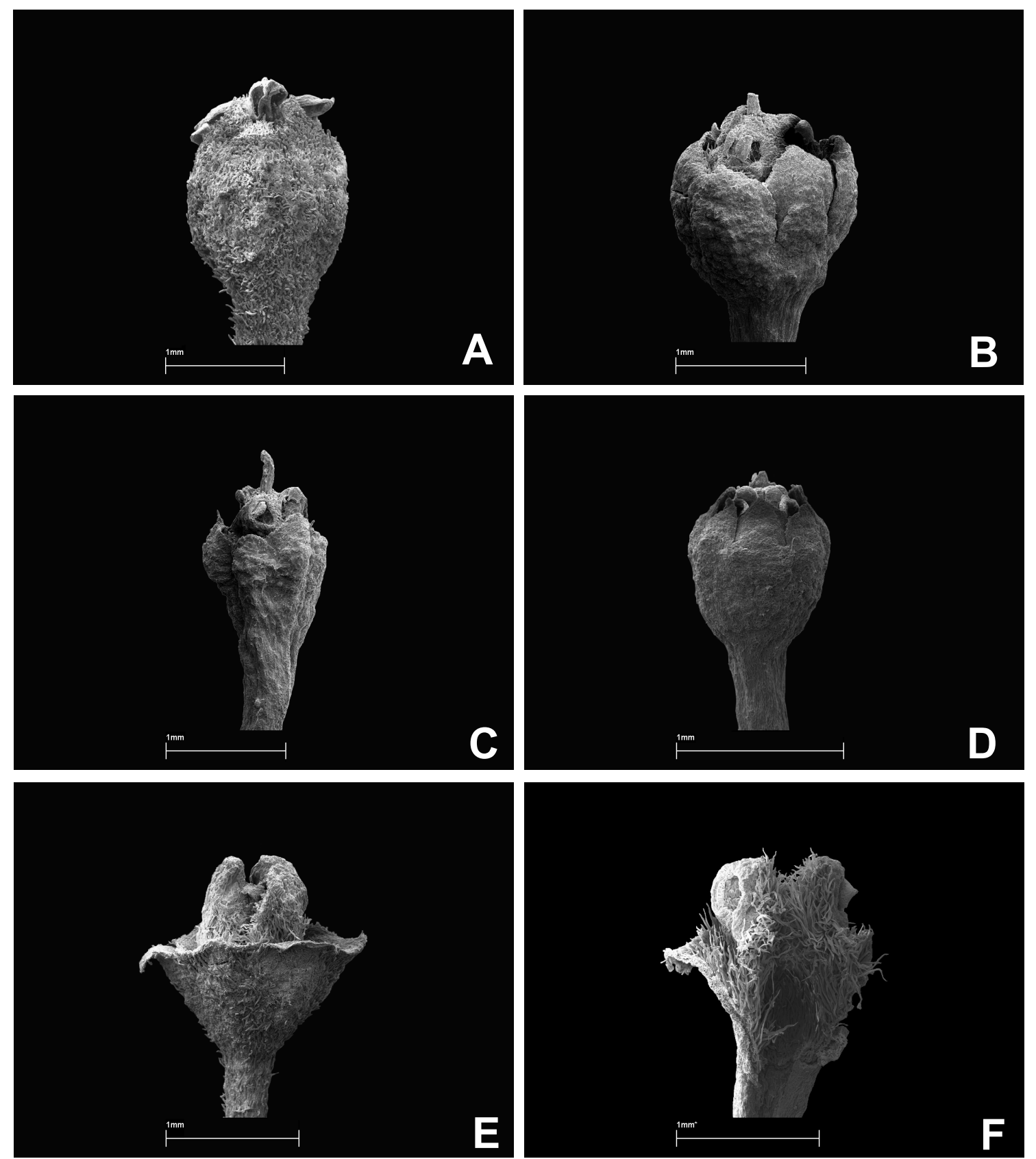

Figura 39: Flores de Clinostemon e Mezilaurus A: Clinostemon mahuba (Krukoff 5870). B: M. microphylla (isótipo); C-D: flores com tépalas menores que o receptáculo, $1 / 3^{-1 / 5}$ do comprimento da flor. C: M. glabriantha (Barbosa \& Alves 1012); D. M. duckei (Vicentini et al. 654). E: flor de M. subcordata (Ferreira et al. 8772). F: receptáculo internamente pubescente de M. vanderwerffii (Alves \& Garcez 45). 

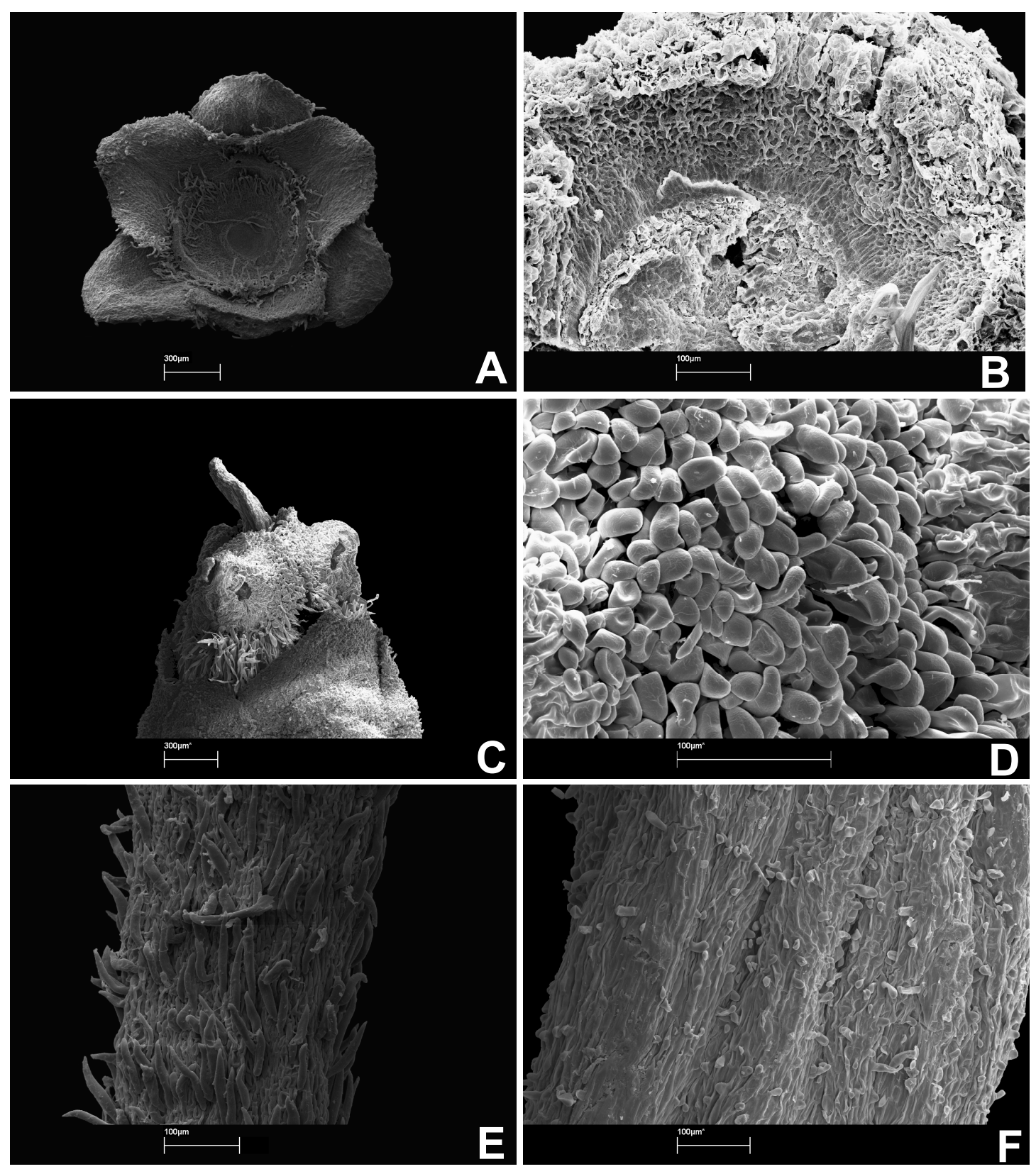

Figura 40: Indumento das flores e pedicelos de Mezilaurus. A: flores internamente pubescentes $M$. subcordata (Ferreira et al. 8772); B: flores internamente glabras de $M$. glabriantha (Barbosa \& Alves 1012); C: detalhe da flor com tricomas papilosos de $M$. crassiramea (Alves 530); D: detalhe dos tricomas papilosos na flor de M. crassiramea (Alves 530); E: detalhe dos tricomas não papilosos no pedicelo de M. subcordata (Ferreira et al. 8772); F: detalhe dos tricomas papilosos no pedicelo de M. crassiramea (Alves 530). 


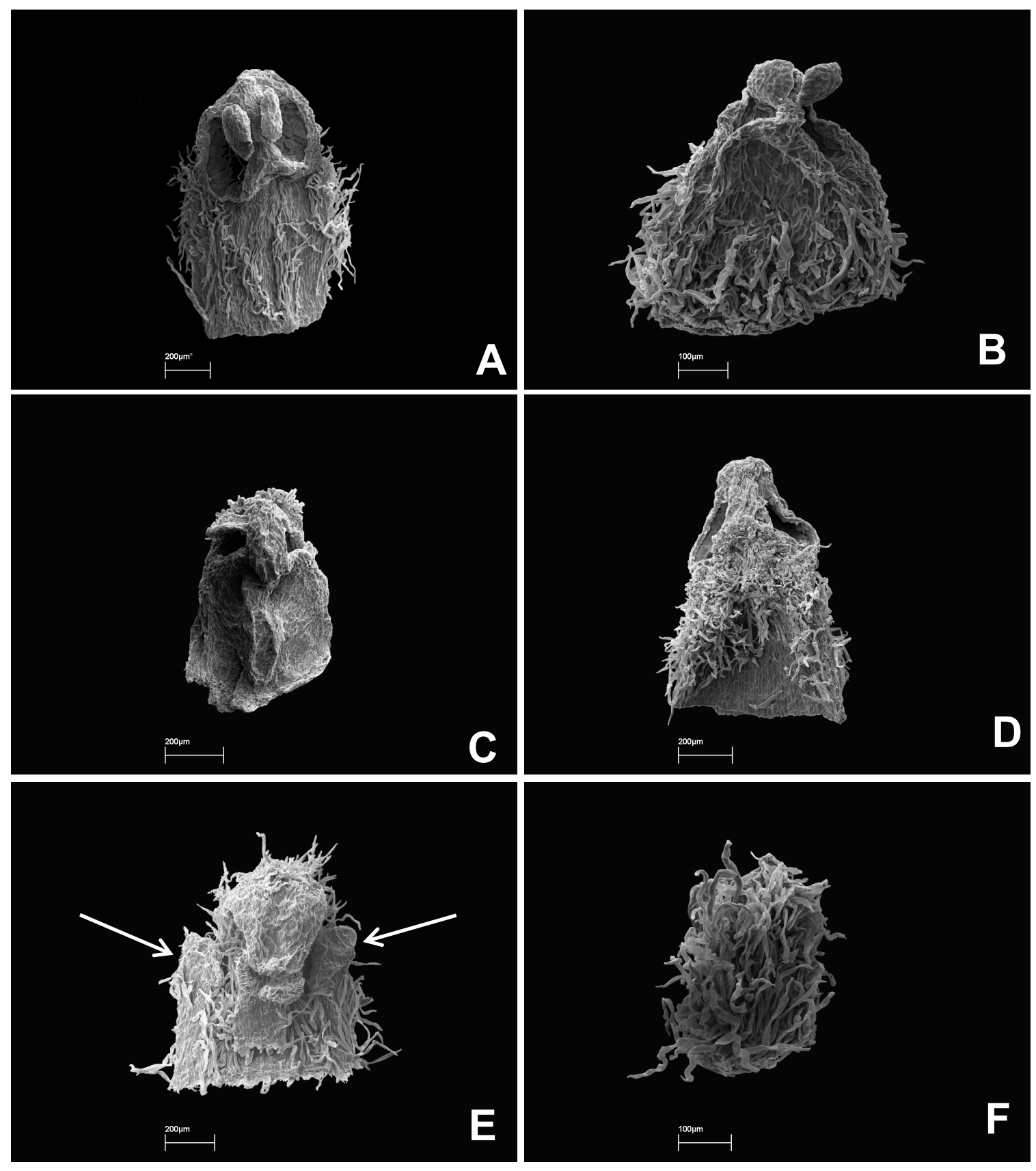

Figura 41: Estames de Clinostemon e Mezilaurus. A-E: estames férteis. A: $M$. navalium (Ramalho \& Silva 1); B: M. duckei (Vicentini et al. 654); C: M. glabriantha (Barbosa \& Alves 1012); D: M. subcordata (Ferreira et al. 8772); E: Clinostemon mahuba (Krukoff 5870). F. estaminódios de M. duckei (Vicentini et al. 654). 
Os estames são exsertos, porém, inclusos em M. duckei, M. introrsa, M. microphylla e $M$. synandra, raramente em M. itauba. Os estames se apresentam livres e coniventes ou conados em M. decurrens e M. synandra, formando um tubo com uma abertura apical, pela qual o estilete atravessa e permanece exposto para fora da flor (Figura 40, C). Em M. synandra por vezes podese observar os estames unidos no ápice dos frutos, enquanto nas outras espécies, estes permanecem na base da cúpula ou são destacados na frutificação.

As anteras de Clinostemon e Mezilaurus possuem dois locelos, comumente extrorsos, latrorsos ou apicais, porém, estes são introrsos em M. subcordata e M. introrsa. As anteras são eretas em Mezilaurus (Figura 41, A-D), todavia, encurvadas em Clinostemon (Figura 41, E). Os filetes são geralmente pubescentes, entretanto, estes são glabros em M. glabriantha (Figura 41, C). Em todas as espécies de Mezilaurus há ausência de glândulas nas flores, contudo, em Clinostemon pode-se verificar um par de glândulas na base dos filetes (Figura 41, E).

Em Lauraceae geralmente ocorre redução total de uma série de estames ou sua substituição por estaminódios. Esta é uma peculiaridade de Clinostemon e Mezilaurus, uma vez que na grande maioria dos gêneros, os estaminódios correspondem à série IV do androceu. Em Clinostemon ocorre a permanência completa dos estaminódios das séries I, II e IV do androceu. Em Mezilaurus, esta característica ocorre apenas em M. duckei (Figura 41, F) e M. thoroflora. Os estaminódios estão ausentes em M. caatingae, M. decurrens, M. microphylla, M. navalium, M. sprucei e M. synandra. Em M. crassiramea, M. glabriantha, M. introrsa, M. itauba, M. revolutifolia, M. subcordata e M. vanderwerffii os estaminódios estão ausentes ou presentes somente 1 por flor, representando à série IV ou raramente I ou II do androceu.

O gineceu fornece poucas características diagnósticas para a distinção das espécies, sendo as mais importantes o indumento e o tamanho do estilete em relação ao ovário. O estilete é exserto após a antese na maioria das espécies (Figura 40, C), porém, este é incluso em M. duckei 
(Figura 39, D). O pistilo é pubescente em M. decurrens, M. subcordata e M. synandra, enquanto nas outras espécies, este é glabro. O estilete é cilíndrico e os estigmas lobados.

\section{Frutos}

Clinostemon e Mezilaurus possuem frutos que correspondem ao padrão encontrado na maioria das Lauraceae, uma baga monospérmica. Quando imaturos os frutos são verdes com pontos brancos (Figura 42, A), enquanto na maturidade, estes são atropurpúreos (Figura 42, B) e com frequência glaucos. Os frutos são elipsóides a obovóides, geralmente glabros ou pubescentes no ápice em M. synandra. A cúpula é pateliforme a plana, pouco variável na forma e, quando pateliforme, envolve cerca de $1 / 12^{-1} / 15$ do fruto. As cúpulas podem ser pubescentes a pubérulas, interna e externamente.

O diâmetro da cúpula em relação ao comprimento do pedicelo na frutificação é uma característica útil na taxonomia do grupo. Na maioria das espécies a cúpula possui diâmetro do mesmo tamanho a ligeiramente maior que o comprimento do pedicelo na frutificação, todavia, em $M$. sprucei e $M$. thoroflora o pedicelo na frutificação é sempre maior que o diâmetro da cúpula. Em todas as espécies estudadas, as tépalas são persistentes até mesmo após o fruto cair da cúpula, contudo, mudam sua forma, tornando-se mais largas e inconspícuas (Figura 42, C), o que fez com que Rohwer (1993a) as citasse como decíduas.

Portanto, as principais características reprodutivas para separação de Mezilaurus e Clinostemon é a presença neste último gênero de anteras encurvadas e um par de glândulas na base dos filetes. Por outro lado, as principais características reprodutivas úteis na delimitação das espécies de Mezilaurus incluem o tipo de inflorescência, presença de bractéolas decíduas ou persistentes, indumento da inflorescência, pedicelos e flores, relação entre o tamanho do pedicelo 
e a flor, relação entre o tamanho das tépalas e o comprimento da flor e a presença ou ausência de séries completas de estaminódios. 


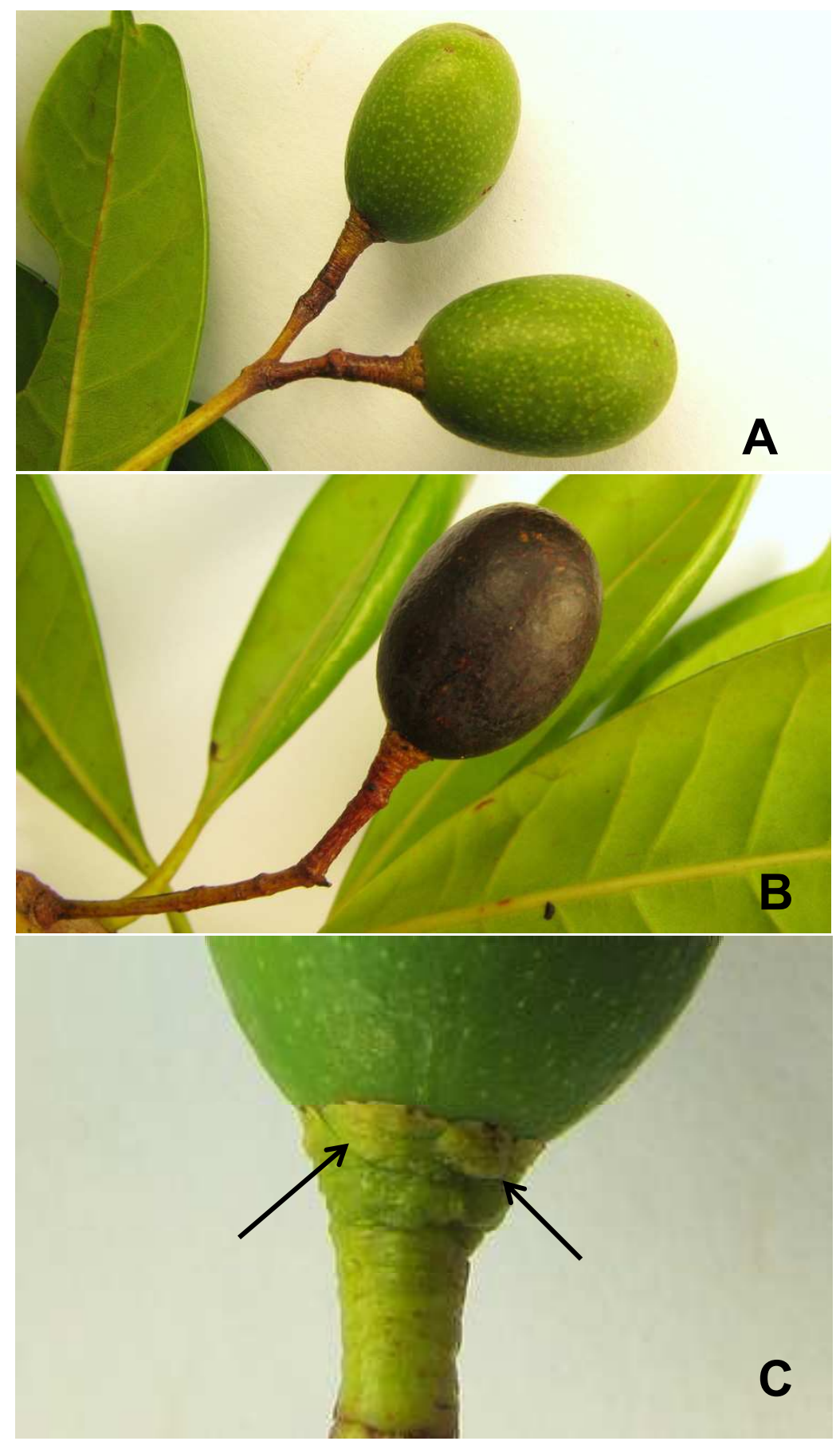

Figura 42: Frutos de Mezilaurus. A-C: M. revolutifolia. A: frutos imaduros; B: frutos maduros; C: detalhe da cúpula pateliforme com tépalas persistentes (setas) (Fotos: Alex Popovkin). 


\subsection{Relações Infragenéricas}

Mezilaurus diferencia-se de Clinostemon por características citadas na tabela 7 e indicadas na figura 8 e 41.

Dentro de Mezilaurus, as principais características utilizadas para separação das espécies foram: a presença ou ausência de tricomas nos ramos, folhas, flores externamente, filetes e pistilo, tipo de inflorescência, presença de uma ou três bractéolas na base das flores, tamanho das tépalas em relação ao comprimento da flor, posição de abertura dos locelos e a presença ou ausência de ciclos completos de estaminódios nas séries I, II e IV do androceu.

Mezilaurus caatingae apresenta três bractéolas na base dos pedicelos, característica também encontrada em Clinostemon mahuba, uma espécie considerada como Mezilaurus mahuba por van der Werff (1987). Entretanto, C. mahuba possui râmulos velutinos a tomentosos, base foliar fortemente assimétrica, estames com anteras encurvadas, um par de glândulas na base dos filetes e nove estaminódios, representando as séries I, II e IV do androceu. Todas as outras espécies de Mezilaurus apresentam apenas uma bractéola na base de cada pedicelo.

Mezilaurus crassiramea, M. duckei e M. thoroflora compartilham a presença de tricomas conspícuos na face abaxial das lâminas foliares, inflorescências em duplos racemos e bractéolas persistentes. Por outro lado, as outras espécies do gênero possuem lâminas foliares glabras a subglabras na face abaxial, inflorescências em racemos com flores agrupadas no ápice dos ramos laterais (raramente flores laxas) e bractéolas decíduas. Mezilaurus duckei e M. thoroflora apresentam nove estaminódios, representando as séries I, II e IV do androceu, ao passo que em M. crassiramea estes estão ausentes ou raramente presentes em número de um, representando a IV série do androceu.

A maioria das espécies de Mezilaurus possuem anteras extrorsos, latrorsos ou apicalextrorsos, no entanto, $M$. introrsa e M. subcordata apresentam anteras introrsas. 
A relação entre o comprimento das tépalas e o da flor é uma característica útil para separação das espécies de Mezilaurus. As tépalas menores que o receptáculo da flor, de $1 /{ }_{3}-1 / 5$ do comprimento da flor, ocorrem em M. caatingae, M. crassiramea, M. duckei, M. glabriantha, M. itauba, M. decurrens, M. navalium, M. sprucei, M. subcordata e M. thoroflora. Todavia, tépalas

do mesmo tamanho ou maiores que o receptáculo, cerca de $1 / 2$ do comprimento da flor (nunca $1 / 3$ ) ocorrem em M. introrsa, M. microphylla, M. revolutifolia, $M$. synandra e $M$. vanderwerffii.

Dentro de cada grupo supracitado, o formato das folhas, relação entre seu comprimento e largura, representatividade do pecíolo na folha, presença ou ausência de tricomas nas inflorescências, flores externamente, estames e pistilo, tamanho do pedicelo, relação entre pedicelo e a cúpula, presença de tricomas nos frutos foram as principais características para separar as espécies.

\subsection{Distribuição Geográfica}

Espécies de Clinostemon e Mezilaurus são encontradas somente na região neotropical da América do Sul e a maioria das espécies ocorre entre os paralelos do Equador e de Capricórnio. Clinostemon ocorre no Brasil e Perú (Figura 32), enquanto Mezilaurus está representado desde a Bolívia, Peru, Equador, Colômbia, Venezuela, Guiana, Suriname, Guiana Francesa até o sudeste do Brasil (Figura 43).

Ao norte, Clinostemon mahuba e as espécies de Mezilaurus, M. caatingae, M. crassiramea, M. itauba, M. subcordata, M. sprucei e M. thoroflora podem alcançar além dos limites do paralelo do Equador. Mezilaurus crassiramea atinge até $6^{\circ} 45^{\prime} \mathrm{N}$ no estado de Bolivar, Venezuela, enquanto ao sul M. navalium não ultrapassa $22^{\circ} 45^{\prime}$ S no estado do Rio de Janeiro. 


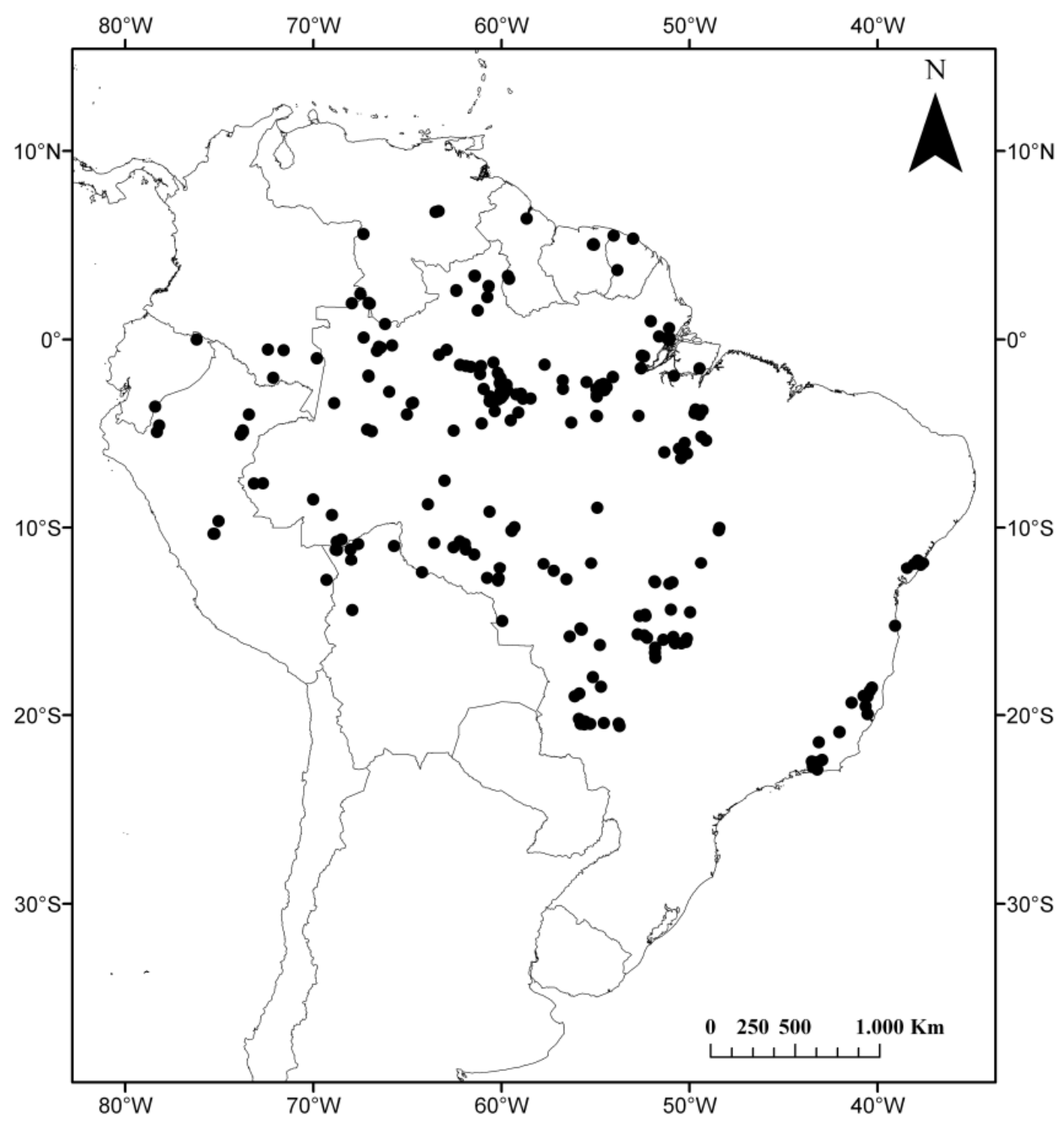

Figura 43: Mapa de distribuição geográfica do gênero Mezilaurus (pontos). 
Na Floresta Atlântica brasileira está o limite de distribuição leste do gênero com $M$. revolutifolia alcançando $37^{\circ} 55^{\prime} \mathrm{W}$ no estado da Bahia, por outro lado, $M$. itauba foi encontrada até $78^{\circ} 50^{\prime} \mathrm{W}$ na província de Zamora-Chinchipe no Equador.

O principal centro de diversidade de Mezilaurus está localizado na Amazônia, sendo que das 15 espécies do gênero reconhecidas no presente trabalho, 10 ocorrem na região e oito são exclusivas. Somente nas províncias de Imerí, Roraima e Varzea (Figura 1), em conjunto, foram encontradas nove espécies de Mezilaurus. Na região do Cerrado brasileiro (sub-região Chaquenha) ocorrem quatro espécies, contudo, somente M. microphylla é exclusiva. A Floresta Atlântica brasileira (sub-região Paranaense), é representada por cinco espécies, no entanto, apenas $M$. glabriantha, M. navalium e M. revolutifolia são exclusivas da região. Mezilaurus vanderwerffii é uma espécie característica do Pantanal matogrossense e sul-matogrossense e no Cerrado e floresta estacional do seu entorno.

Mezilaurus crassiramea apresenta a mais ampla distribuição geográfica do gênero, encontrada desde a Venezuela e Guiana até o sudeste do Brasil, nas regiões Amazônica (subregião Amazônica), no Cerrado (sub-região Chaquenha) e Floresta Atlântica (sub-região Paranaense). Mezilaurus itauba também possui distribuição bastante ampla, ocorrendo desde o Peru, Equador, Colômbia, Venezuela, Suriname, Guiana Francesa até o centro-oeste do Brasil e Bolívia. A espécie está representada em quase toda a área de ocorrência da Amazônica (subregião Amazônica).

Das 15 espécies de Mezilaurus, reconhecidas no presente trabalho, 13 ocorrem no Brasil e destas, nove apresentam distribuição restrita ao país. Por outro lado, mesmo restritas ao Brasil, várias dessas espécies possuem extensas distribuições, enquanto outras são endêmicas e conhecidas de poucas coleções. No Peru e Venezuela ocorrem três espécies, todavia, nenhuma destas é restrita. Todos os demais países com ocorrência de Mezilaurus estão representados por uma ou duas espécies. 
No Brasil, M. caatingae, M. decurrens e M. duckei são exclusivas do estado do Amazonas, enquanto na região central, M. microphylla possui distribuição restrita ao estado do Tocantins. Mezilaurus vanderwerffii, no entanto, foi registrada somente para o Pantanal matogrossense e sul-matogrossense e no Cerrado e floresta estacional do seu entorno. Na região sudeste do Brasil, M. navalium é exclusiva do estado do Rio de Janeiro, M. glabriantha ocorre somente no Espírito Santo e M. revolutifolia é endêmica do nordeste do estado da Bahia. Por outro lado, M. synandra apresenta distribuição nos estados do Amazonas, Tocantins e Bahia.

No oeste da América do Sul, M. introrsa é endêmica do departamento de Vaupés no sudeste da Colômbia, enquanto $M$. thoroflora é restrita à região Cuyuni-Mazaruni, norte da Guiana.

Clinostemon mahuba apresenta disjunção no Brasil e Peru (Figura 32), enquanto Mezilaurus crassiramea apresenta ocorrência no extremo leste do estado de Minas Gerais e Espírito Santo, no Cerrado do Brasil central e Amazônia. Já Mezilaurus synandra, ocorre exclusivamente no Brasil, mas possui três regiões disjuntas de ocorrência: Amazônia central, região central do Tocantins e sul da Bahia.

Clinostemon e Mezilaurus desenvolvem-se em diferentes habitats, todavia, a maior parte das espécies é encontrada na floresta de "terra firme" da Bacia Amazônica e adjacências. Clinostemon mahuba é característica da floresta inundada sazonalmente ou "mata de várzea" próximas à foz do rio Amazonas, enquanto no Peru, esta espécie ocorre na floresta de terra firme e mata ciliar. Mezilaurus introrsa também desenvolve-se na floresta inundada sazonalmente, ambiente intitulado de "igapó" no departamento de Vaupés, Colômbia. Já Mezilaurus crassiramea está representada desde as florestas estacionais na Venezuela, em algumas áreas fragmentadas na Amazônia, no Cerrado e Floresta Atlântica. 
Mezilaurus itauba está representada em quase toda a Bacia Amazônica, muito comum na floresta de "terra firme", "mata de várzea" e "caatinga amazônica", mas ocorre também na floresta estacional do entorno amazônico.

Cinco espécies possuem distribuições exclusivamente extra-amazônicas. Mezilaurus vanderwerffii é particular de áreas de Cerrado da região oeste do Pantanal e da floresta estacional do seu entorno; M. microphylla ocorre na floresta estacional e Cerrado da região central do estado do Tocantins; Mezilaurus navalium, M. glabriantha e M. revolutifolia são exclusivas da Floresta Atlântica Brasileira.

Espécies de Mezilaurus estão representadas em elevações quase sempre abaixo de $500 \mathrm{~m}$ de altitude. Todavia, na Floresta Atlântica, M. navalium ocorre em cotas altitudinais de 600 a 930 m e M. glabriantha entre 650 e $800 \mathrm{~m}$ de altitude. Mezilaurus itauba pode estar representada em diversas altitudes, desde o nível do mar na Amazônia até 1400 m no Equador. Já M. crassiramea ocorre desde 15 m de altitude no ecótono Amazônia-Cerrado e na Amazônia oriental até $1000 \mathrm{~m}$ no Brasil central.

\subsection{Conservação}

Várias espécies do gênero Mezilaurus possuem "itaúba" como nome popular, apresentando madeira de excelente qualidade, especialmente no que se refere à sua durabilidade quando em contato com a água, o que as fazem muito exploradas para a construção de embarcações. Embora tais qualidades tenham sido mais frequentemente atribuídas a M. itauba, uma espécie com distribuição geográfica relativamente ampla, as demais espécies também são intensamente exploradas, o que é bastante preocupante, uma vez que apresentam distribuição geográfica mais restrita, com populações menores, mais suceptíveis a perdas genéticas que podem levar à extinção. 
Das 15 espécies reconhecidas no presente trabalho, oito (53\%) apresentam risco de extinção considerável. Quatro espécies foram categorizadas como "Dados Deficientes" (DD) por serem conhecidas somente por um espécime. A categoria "Criticamente em Perigo" (CR) foi sugerida para quatro espécies que apresentam distribuição geográfica restrita (IUCN 2001).

Mezilaurus caatingae, M. decurrens, M. glabriantha, M. introrsa, M. microphylla e $M$. revolutifolia são restritas a uma localidade. Em especial, $M$. caatingae, M. decurrens, $M$. introrsa, M. microphylla e M. thoroflora são conhecidas apenas pelos espécimes-tipo. Por outro lado, Mezilaurus sprucei e M. subcordata foram categorizadas como "Quase Ameaçada" (NT) por apresentarem distribuições amplas, mas com poucos espécimes coletos nos últimos 20 anos. Mezilaurus crassiramea, M. itauba, M. revolutifolia, M. synandra e $M$. vanderwerffii foram consideradas como "Menor Preocupação" (LC) pois apresentam distribuição geográfica ampla e são largamente conhecidas tanto através de material de herbário quanto em campo (IUCN 2001).

A madeira de Mezilaurus navalium, o "tapinhoã”, desde 1754 foi utilizada para confecção dos tonéis para a marinha real e empregada no forro de embarcações até quase ser extinta (Cabral 2008). Nos últimos 20 anos, M. navalium foi recoletada somente quatro vezes e apenas na Reserva Biológica do Tinguá, município de Nova Iguaçu, Rio de Janeiro. Por essa razão, nós sugerimos que a espécie mude de categoria, devendo ser considerada como "Criticamente em Perigo" (CR) (B1a+bii, B2bii) (IUCN 2001).

Mezilaurus itauba, a "itaúba", há mais de 160 anos é citada como uma das espécies mais exploradas na região amazônica para utilização da madeira, principalmente em obras navais (Hooker 1851). Apesar de ter sido bem amostrada em sua área de ocorrência, é relatada como quase extinta no estado de Rondônia no Brasil e foi considerada como "Vulnerável" (VU) (IUCN 2001). Aqui, nós sugerimos a alteração de sua categoria para "Menor Preocupação" (LC), pois apresenta distribuição geográfica ampla e é bem conhecida tanto através de espécimes de herbário quanto em campo. 
Várias espécies de Mezilaurus foram consideradas raras por Baitello et al. (2009) e inúmeras áreas de ocorrência dessas espécies, através do grau de endemismo, foram analisadas como importantes para a conservação da flora brasileira (Kasecker et al. 2009). 


\subsection{Lista de Espécies}

1. Mezilaurus Taub.

1.1. M. caatingae van der Werff

1.2. M. crassiramea (Meisn.) Taub. ex Mez

1.3. M. decurrens (Ducke) Kosterm.

1.4. M. duckei van der Werff

1.5. M. glabriantha F. M. Alves \& V. C. Souza

1.6. M. introrsa F. M. Alves, van der Werff \& V. C. Souza

1.7. M. itauba (Meisn.) Taub. ex Mez

1.8. M. microphylla F. M. Alves \& V. C. Souza

1.9. M. navalium (Meisn.) Taub. ex Mez

1.10. M. revolutifolia F. M. Alves \& P. R. L. Moraes

1.11. M. sprucei (Meisn.) Taub. ex Mez

1.12. M. subcordata (Ducke) Kosterm.

1.13. M. synandra (Mez) Kosterm.

1.14. M. thoroflora van der Werff

1.15. M. vanderwerffii F. M. Alves \& J. B. Baitello

2. Clinostemon Kuhlm. \& A. Samp.

2.1. C. mahuba (A. Samp.) Kuhlm. \& A. Samp. 


\section{Conclusões}

- O "grupo Mezilaurus", como circunscrito por Rohwer \& Rudolph (2005), não foi confirmado como clado em nenhuma das análises, com posicionamento incerto de Chlorocardium e Anaueria.

- O clado Mezilauroides, sensu Rohwer \& Rudolph (2005), com Mezilaurus, Sextonia e Williamodendron apresentou elevado suporte em praticamente todas as análises, resultado confirmado por análises prévias de Chanderbali et al. (2001) e Rohwer \& Rudolph 2005. Uma provável sinapomorfia do clado é a presença de crescimento rítmico apositivo nos ramos, acarretando folhas congestas na extremidade dos ramos.

- Mezilaurus, como circunscrito por van der Werff (1987), não é monofilético, uma vez que M. mahuba emergiu como grupo-irmão de Sextonia. Para Mezilaurus se tornar monofilético, foi removido de sua circunscrição a espécie Mezilaurus mahuba e restabelecida em Clinostemon.

- Mezilaurus apresenta aqui circunscrição mais restrita do que a apresentada por van der Werff (1987). O gênero pode ser definido pela combinação das seguintes características: árvores ou arbustos com folhas congestas no ápice dos ramos, resultado de seu crescimento rítmico apositivo, inflorescências do tipo duplo racemo (dibótrio), flores bissexuadas, três estames férteis, representando a série III do androceu, anteras biloceladas, eretas, ausência de glândulas nas flores e cúpula de pateliforme a plana com tépalas persistentes.

- Foram reconhecidas 15 espécies para Mezilaurus no presente trabalho, três a menos do que o apresentado na última revisão de van der Werff (1987). Duas espécies com anteras tetraloceladas incluídas em Mezilaurus foram transferidas para Williamodendron por Kubitzki \& Richter (1987); uma espécie de Mezilaurus (sensu van der Werff 1987) com 
anteras encurvadas e um par de glândulas nos filetes foi aqui restabelecida como Clinostemon; sete binômios considerados por van der Werff (1987) foram sinonimizados e quatro novas espécies foram descritas para a ciência:

- Mezilaurus glabriantha F. M. Alves \& V. C. Souza sp. nov., Mezilaurus introrsa F. M. Alves, van der Werff \& V. C. Souza sp. nov., Mezilaurus microphylla F. M. Alves \& V. C. Souza sp. nov. e Mezilaurus revolutifolia F. M. Alves \& P. R. L. Moraes sp. nov.

- Clinostemon foi restabelecido e deve ser circunscrito com as seguintes características: árvores com folhas congestas no ápice dos ramos, resultado de seu crescimento rítmico apositivo, inflorescências do tipo racemo, flores bissexuadas, três estames férteis, representando a série III do androceu, anteras biloceladas, encurvadas, um par de glândulas nos filetes, cúpula de pateliforme a plana com tépalas persistentes.

- Foi reconhecida no presente trabalho apenas uma espécie do gênero, Clinostemon mahuba (A. Samp.) Kuhlm. \& A. Samp. Clinostemon maguireanum é uma combinação do basiônimo de Mezilaurus thoroflora e pertence a circunscrição de Mezilaurus, enquanto M. triunca foi aqui sinonimizada em Clinostemon mahuba.

- A presença de anteras encurvadas e um par de glândulas nos filetes em Clinostemon são as principais características morfológicas que distinguem este gênero de Mezilaurus.

- O grande volume de espécimes analizados foi importante para reexaminar a circuncrição das espécies e fundamental para concluir pela falta de descontinuidade de alguns espécimes e suas sinonimizações. 


\section{Referências Bibliográficas}

Allemão, F. F. Laurinea. Silvia (gen. nov.) navalium (sp. nov.). Opúscula ("Plantas novas do Brasil”). 4p.

Allen, C.K. 1945. Studies in the Lauraceae VI. Preliminary survey of the Mexican and Central American species. Journal of the Arnold Arboretum 24: 280-434.

Allen, C. K. 1963. Lauraceae. Pp. 44-122. In: Maguire, B. \& Wurdack, J. J. The Botany of the Guayana Highland - Part V. Memoirs of the New York Botanical Garden 10.

Allen, C.K. 1966. Notes on Lauraceae of Tropical America I. The generic status of Nectandra, Ocotea and Pleurothyrium. Phytologia 13 (3): 221-231.

Alves, F. M. \& Baitello, J. B. 2008. Uma nova espécie de Mezilaurus Taubert (Lauraceae) para a flora brasileira. Acta Botanica Brasilica 22 (2): 355-358.

Alves, J. C. Z \& Miranda, I. S. 2008. Análise da estrutura de comunidades arbóreas de uma floresta amazônica de terra firme aplicada ao manejo florestal. Acta Amazônica 38 (4): $657-666$.

Andrade-Lima, D. 1973. Notas sobre a dispersão de algumas espécies vegetais no Brasil. Anais da Sociedade Biológica de Pernambuco 11 (1): 25-49.

Archer, W. A. 1962. Adolpho Ducke, Botanist of the Brazilian Amazon. Taxon 11: 233-242.

Assis, L. C. S. 2010. Sistemática e Filogenia: filogenia do complexo Ocotea e revisão do grupo Ocotea indecora (Lauraceae). Tese (Doutorado) - Instituto de Biociências da Universidade de São Paulo, Departamento de Botânica.

Assis, L. C. S.; Forzza, R. C. \& van der Werff, H. 2005. A família Lauraceae na Reserva Biológica da Represa do Grama, Descoberto, Brasil. Boletim de Botânica 23: 113-139.

Baitello, J. B. 2001. Novas espécies de Lauraceae para a flora brasileira. Acta Botanica Brasilica 14 (3): 445-450. 
Baitello, J. B. \& Coe-Teixeira, B. 1987. Flora Fanerogâmica da Reserva do Parque Estadual das Fontes do Ipiranga. Hoehnea 14: 63-74.

Baitello, J.B.; Lorea-Hernández, F. G. L.; de Moraes, P. L. R.; Esteves, R. \& Marcovino, J. R. 2003. Lauraceae. Pp. 149-223. In: Wanderley, M. G. L.; Shepherd, G. J.; Giulietti, A. M. \& Melhem, T. S (eds). Flora Fanerogâmica do Estado de São Paulo. v 3. São Paulo: FAPESP: Rima.

Baitello, J. B.; Quinet, A.; Moraes, P. L. R. \& Rodrigues, W. A. 2009. Lauraceae. Pp. 201-207. In: Giulietti, A. M.; Rapini, A.; Andrade, M. J. G.; Queiroz, L. P. \& Silva, J. M. C. (org.). Plantas raras do Brasil. Belo Horizonte, MG : Conservação Internacional.

Baldwin, B. G. 1992. Phylogenetic utility of the internal transcribed spacers of nuclear ribosomal DNA in plants: an example from the Compositae. Molecular Phylogenetics and Evolution 1 (1) 3-16.

Baldwin, B. G.; Sanderson, M. J.; Porter, J. M. \& Wojciechowski, M. F.; Campbell, C. S. \& Donoghue. M. J. 1995. The ITS region of nuclear ribosomal DNA: a valuable source of evidence on Angiosperm phylogeny. Annals of the Missouri Botanical Garden 82 (2) $247-277$.

Barroso, G.M.; Guimarães, E.F.; Ichaso, C.L.F.; Costa, C.G. \& Peixoto, A.L. 2002. Sistemática de Angiospermas do Brasil. v. 1, 2ed. Viçosa, Universidade Federal de Viçosa.

Barroso, L. J. 1949. Chave para Determinação de gêneros indígenas e exóticos da família Lauraceae no Brasil. Rodriguésia 12 (24): 137-146.

Béguin, D.; Spichiger, R. \& Miège, J. 1985. Las Lauráceas del Arborétum Jenaro Herrera (provincia de Requena, departamento de Loreto, Peru): contribuición al estudio de la flora y de la vegetación de la Amazonia peruana. VIII. Candollea 40: 253-304.

Bentham, G. 1878. Misanteca anacardioides, Benth. Hooker's Icones Plantarum 13 (3): 46-47. Bentham, G. \& Hooker, J. D. 1880. Laurineae. Genera Plantarum 3 (1) 146-164. 
Bernardi, L. 1962. Lauráceas. Talleres Graficos Universitarios. Mérida.

Brummitt, R. K. \& Powell, C. E. 1992. Authors of plant names. Royal Botanic Gardens, Kew. $732 \mathrm{p}$.

Burger, W. 1988. A new genus of Lauraceae from Costa Rica, with comments on problems of generic and specific delimitation within the family. Brittonia 40 (3): 275-282.

Cabral, D. C. 2008. Floresta, política e trabalho: a exploração das madeiras-de-lei no Recôncavo da Guanabara (1760-1820). Revista Brasileira de História 28 (55): 217-241.

Caiafa, A. N. \& Martins, F. R. 2007. Taxonomic identification, sampling methods, and minimum size of the tree sampled: implications and perspectives for studies in the Brazilian Atlantic Rainforest. Functional Ecosystems and Communities 1 (2): 95-104

Castaño-Arboleda, N.; López, D. C. \& Rodríguez, E. O. 2007. Ecología, aprovechamiento y manejo sostenible de nueve especies de plantas del departamento del Amazonas, generadoras de productos maderables y no maderables. Bogotá, Colombia: Instituto Amazónico de Investigaciones Científicas - Sinch i-. Corporación para el Desarrollo Sostenible del Sur de la Amazonia, CORPOAMAZONIA. 266p.

Castro, A. A. J. F.; Martins, F. R.; Tamashiro, J. Y. \& G. J. Shepherd. 1999. How Rich is the Flora of Brazilian Cerrados? Annals of the Missouri Botanical Garden 86 (1): 192-224

Chanderbali, A. S. 2004. Endlicheria (Lauraceae). Flora Neotropica 91: 1-144.

Chanderbali, A. S.; van der Werff, H. \& Renner. S. S. 2001. The relationships and historical biogeography of Lauraceae: evidence from the chloroplast and nuclear genomes. Annals of the Missouri Botanical Garden 88:104-134.

Chase, M. W. \& Hills, H. G. 1991. Silic gel. An ideal material for field preservation of samples for DNA studies. Taxon 40: 215-220.

Coe-Teixeira, B. 1963. Lauráceas do Estado de São Paulo I. Beilschmiedia, Endlicheria e Aniba.

Boletim do Instituto de Botânica de São Paulo 1: 1-29. 
Coe-Teixera, B. 1965. Lauráceas do Estado de São Paulo II: Cryptocarya. Arquivos de Botânica do Estado de São Paulo 4 (1): 1-9.

Coe-Teixera, B. 1975. Espécies Novas de Nectandra (Lauraceae) da Flora do Brasil. Acta Amazônica 5 (2) 157-171.

Coe-Teixera, B. 1980. Lauráceas do Gênero Ocotea, do Estado de São Paulo. Rodriguésia 52: 55-190.

Corrêa, M. P. \& Penna, L. A. 1969. Dicionário das plantas úteis do Brasil. v. 4. Rio de Janeiro, Ministério da Agricultura.

Corrêa, M. P. \& Penna, L. A. 1975. Dicionário das plantas úteis do Brasil. v. 6. Rio de Janeiro, Ministério da Agricultura.

De Candole, A. 1880. La phytographie. Paris: G. Masson Éditeur.

Douzery, E. J. P.; Pridgeon, A. M.; Kores, P.; Linder, H. P.; Kurzweil, H. \& Chase, M. W. 1999. Molecular phologenetics of Diseae (Orchidaceae): a contribution from nuclear ribosomal ITS sequences. American Journal of Botany 86 (6): 887-889.

Doyle, J. J. \& Doyle, J. L. 1987. A rapid DNA isolation procedure for small quantities of fresh leaf tissue. Phytochemical Bulletin 19: 11-15.

Downie, S. R \& Katz-Downie, D. S. 1996. A molecular phylogeny of Apiaceae subfamily Apioideae: evidence from nuclear ribosomal DNA internal transcribed spacer sequences. American Journal of Botany 83: 234-251.

Ducke, A. 1935. Notes on the itaúba trees: the amazonian species of the genus Silvia Allem. Tropical Woods 42: 18-21.

Felsenstein, J. 1985. Confidence limits on phylogenies: an approach using the bootstrap. Evolution 39: 783-791.

Ferreira, M. E. \& Gattapaglia, D. 1996. Introdução ao uso de marcadores moleculares em análise genética. Brasília: Embrapa Cenargen. 2 ed. 220p. 
Font-Quer, P. 1953. Diccionario de botánica. Barcelona: Labor.

Gentry, A. 1988. Changes in plant community diversity and floristic composition on environmental and geographical gradients. Annals of the Missouri Botanical Garden 75: $1-34$.

Hall, T. A. 1999. BioEdit: a user-friendly biological sequences alignment editor and analysis program for Windows 95/98/NT. Nucleic Acids Symposium Series 41: 95-98.

Harris, J. G. \& Harris, M. W. 1994. Plant identification terminology: an illustrated glossary. Utah, Spring Lake.

Hickey, L. J. 1973. Classification of the architecture of dicotyledonous leaves. American Journal of Botany 60 (1): 17-33.

Hoehne, F. C. \& Kuhlmann, J. G. 1951. Índice bibliográfico e número das plantas colhidas pela comissão Rondon ou Comissão de Linhas Telegráficas, Estratégicas de MatoGrosso ao Amazonas, de 1908 até 1923. Secretaria de Agricultura de São Paulo. São Paulo - Brasil. 400 p.

Holmgren, P. K.; Holmgren, N. H. \& Barnett, L. C. 1990. Index herbariorum: the herbaria of the world. $8^{\mathrm{a}}$ ed. New York, New York Botanical Garden.

Hooker, W. J. 1851. Extracts of letters from Richard Spruce, ESQ., written during a botanical mission on the Amazon. Hooker's Journal of Botany and Kew Gardens Miscellany 3: $139-146$.

Huber, J. 1909. Matas e madeiras amazônicas. Boletim do Museu Paraense Emílio Goeldi 6: $91-225$.

Hutchinson, J. 1964. The genera of flowering plants (Angiospermae). v1. Oxford: Claderon Press.

IUCN. 2001. IUCN Red List categories and criteria: Version 3.1. IUCN Species Survival Commission. IUCN, Gland, Switzerland and Cambridge, UK. 
Judd, W. S.; Campbel, C. S.; Kellogg, E. A. \& Stevens, P. F. 1999. Plant Systematics: a phylogenetic approach. Massachusetts U.S.A: Sinauer Associates, Inc. 464p.

Kasecker, T. P.; Silva, J. M. C; Rapini, A.; Ramos-Neto, M. B.; Andrade, M. J. G.; Giulietti, A. M. \& Queiroz, L. P. 2009. Áreas-chave para espécies raras de Fanerógamas. Pp. 433-471. In: Giulietti, A. M.; Rapini, A.; Andrade, M. J. G.; Queiroz, L. P. \& Silva, J. M. C. (org.). Plantas raras do Brasil. Belo Horizonte, MG : Conservação Internacional.

Kelchner, S. A. 2000. The evolution of non-coding chloroplast DNA and ITS application in plant systematic. Annals of Missouri Botanical Garden 87: 482-498.

Kollman, L. J. C.; Fontana, A. P.; Simonelli, M. \& Fraga, C. N. 2007. Angiospermas ameaçadas de extinção no Espírito Santo. Pp. 105-137. In: Simonelli, M. \& Fraga, C. N. (org.). Espécies da flora ameaçadas de extinção no estado do Espírito Santo. Vitória: IPEMA.

Kostermans, A. J. G. H. 1936a. Revision of the Lauraceae I. Recueil des Travaux Botanisques Néerlandais 33: 719-757.

Kostermans, A. J. G. H. 1936b. Studies in South American Malpighiaceae, Lauraceae and Hernandiaceae, especially of Surinam. Mededeelingen van bet Botanisch Museum em Herbarium van de Rijks-Universiteit te Utrecht 25 (13): 1-144.

Kostermans, A. J. G. H. 1937. Revision of the Lauraceae II. The genera Endlicheria, Cryptocarya (American species) and Licaria. Recueil des Travaux Botaniques Néerlandais 34: 500-605.

Kostermans, A. J. G. H. 1938a. Chronica Botanica 4: 14. 1938.

Kostermans, A. J. G. H. 1938b. Revision of the Lauraceae V. A monograph of the genera: Anaueria, Beilschmiedia (American species) and Aniba. Recueil des Travaux Botaniques Néerlandais 35: 835-931. 
Kostermans, A. J. G. H. 1938c. Revision of the Lauraceae III. The genera Aiouea, Systemonodaphne, Urbanodendron, Mezilaurus; additions and corrections to Licaria and Cryptocarya. Recueil des Travaux Botaniques Néerlandais 35: 56-129.

Kostermans, A. J. G. H. 1952a. A historical survey of Lauraceae. Journal for Scientific Research 1: 1-13.

Kostermans, A. J. G. H. 1952b. A historical survey of Lauraceae: part II. Journal for Scientific Research 1: 14-28.

Kostermans, A. J. G. H. 1952c. A historical survey of Lauraceae: part III. Journal for Scientific Research 1: $29-47$.

Kostermans, A. J. G. H. 1953. Notas sobre as Lauraceae Lauroideae Sul Americanas. Boletim Técnico do Instituto Agronômico do Norte 27-30: 49-75.

Kostermans, A. J. G. H. 1957. Lauraceae. Reinwardtia 4 (2): 193-256.

Kubitzki, K.; Kurz, H. \& Richter, H. G. 1979. Reinstatement of Clinostemon (Lauraceae). Journal of the Arnold Arboretum 60: 515-522.

Kubitzki, K. \& Renner, S. 1982. Lauraceae I (Aniba and Aiouea). Flora Neotropica 31: 1-124.

Kubitzki, K. \& Richter, H. G. 1987. Williamodendron Kubitzki \& Richter, a new genus of neotropical Lauraceae. Botanische Jahrbücher für Systematik, Pflanzengeschichte und Pflanzengeographie 109 (1): 49-58.

Kuhlmann, J. G. \& Sampaio, A. J. 1928. Clinostemon, Kuhlm et A. Samp. n. gen. de Lauraceas da Amazonia. Boletim do Museu Nacional de Rio de Janeiro 4 (2): 57-59.

Kuntze, O. 1891. Lauraceae. Revisio generum plantarum: vascularium omnium atque cellularium multarum secundum leges nomenclaturae internationales, cum enumeratione plantarum exoticarum in itineribus mundi collectarum. vol. 2: Commissionen.: Leipzig: Arthur Felix. London: Dulau \& Co. Milano: U. Hoepli. New York: Gust. E. Stechert. Paris: Charles Klincksieck. 377-1011 p. 
Kurz, H. 2000. Revision der Gattung Licaria (Lauraceae). Mitteilungen aus dem Institut für allgemeine Botanik in Hamburg 28/29: 89-221.

Langenheim, J. H.; Lee, Y. S. \& Martin, S. S. 1973. An evolution and ecological perspective of Amazonian Hylaea species of Hymeneae (Leguminosae: Caesalpinioideae). Acta Amazonica 3 (1): 5-38.

Li, J.; Christophel, D. C.; Conran, J. G. \& Li, H. 2004. Phylogenetic relationships within the 'core' Laureae (Litsea complex, Lauraceae) inferred from sequences of the chloroplast gene matK and nuclear ribosomal DNA ITS regions. Plant Systematics and Evolution 246: 1934.

Li, J.; Conran, J. G.; Christophel, D. C.; Li, Z.; Li, L.; Li, H. 2008. Phylogenetic relationships of the Litsea complex and core Laureae (Lauraceae) using ITS and ETS sequences and morphology. Annals of the Missouri Botanical Garden 95 (4): 580-599.

Lisboa, P. L. B.; Terezo, E. F. M. \& da Silva, J. S. A. 1991. Medeiras Amazônicas: considerações sobre exploração, extinção de espécies e conservação. Boletim do Museu Paraense Emílio Goeld. Série Botânica 7 (2): 521-542.

Lorea-Hernández. F. G. 1995. Mocinnodaphne, un género Nuevo de la familia Lauraceae en la flora de México. Acta Botánica Mexicana 32: 25-32.

Lorenzi, H. 2002. Árvores brasileiras: manual de identificação e cultivo de plantas arbóreas do Brasil. v. 2, 2 ed. Nova Odessa, Editora Plantarum. 368p.

Lundell, C. L. 1969. Studies of American plants I. Wrightia 4 (3): 97-110.

MacGrath, D. G.; Peters, C. M. \& Bentes, A. J. M. 2005. Manejo florestal comunitário para a produção de móveis em pequena escala na Amazônia brasileira. Pp. 261-284. In: Zarin, D. J.; Alavalapati, J. R. R.; Putz, F. E. \& Schmink, M. (org.). As florestas produtivas nos neotrópicos: conservação por meio de manejo sustentável? São Paulo: Editora Peirópolis. 
Madriñán, S. 2004a. Lauraceae. Pp. 204-206. In: Smith, N.; Mori, S. A.; Henderson, A.; Stevenson, D. W. \& Heald, S. V. (eds.). Flowering plants of the neotropics. Princeton, Princeton University Press.

Madriñán, S. 2004b. Rhodostemonodaphne (Lauraceae). Flora Neotropica 92: 1-102.

McNeill, J., Barrie, F.R., Burdet, H.M., Demoulin, V., Hawksworth, D.L., Marhold, K., Nicolson, D.H., Prado, J., Silva, P.C., Skog, J.E., Wiersema, J.H. \& Thurland, N.J. 2007. Código Internacional de Nomenclatura Botânica (Código de Viena 2006). Adotado pelo XVII Congresso Internacional de Botânica, Viena, Áustria, julho de 2005. 181p. (Traduzido por Bicudo, C. E. M. \& Prado, J.).

Medina, J. C. 1966. Flora do Brasil: Dicotiledôneas arbóreas úteis. v. 1. Campinas: Instituto Agronômico de Campinas. 925 p.

Meissner, C. F. 1864. Lauraceae. Pp. 1-260 In: A. L. P. P. De Candolle (ed.). Prodromus Systematis Naturalis Regni Vegetabilis. vol. 15, p. 1. Parisiis: Victoris Masson et Filii.

Meissner, C. F. 1866. Lauraceae. Pp. 136-320 In: Martius, C. F. P. von. Flora Brasiliensis. v. 5, pt. 2. Muchen: Wien Leipzig.

Mendes, S. L. \& M. P. Padovan. 2000. A Estação Biológica de Santa Lúcia, Santa Teresa, Espírito Santo. Boletim do Museu de Biologia Mello Leitão 11/12: 7-34.

Mez, C. 1889. Lauraceae americanae. Jahrbuch des Königlichen Botanischen Gartens und des Botanischen Museums zu Berlin 5: 1-556.

Mez, C. 1892. Spicilegium Laureanum. Arbeiten Königlichen Botanischen Garten zu Breslau 1: $71-166$.

Mez, C. 1905. Additamenta monographica 1904. Bulletin de L'Herbier Boissier 5 (2): 232 247.

Mez, C. 1920. Additamenta monographica 1919. Repertorium specierum novarum regne vegetabilis 16: $305-312$. 
Mez, C. 1924. Additamenta monographica 1924. Botanisches Archiv 6: 230-231.

Moraes, P. L. R. de. 2005. Sinopse das Lauráceas nos estados de Goiás e Tocantins, Brasil. Biota Neotrópica 5 (2): 1-18.

Moraes, P. L. R. de. 2006. Taxonomy of Cryptocarya species of Brazil. ABC Taxa Series 1: 1191.

Mori, S. A., Boom, B. M. \& Prance, G. T. 1981. Distrubuition patterns and conservation of eastern Brazilian coastal forest species. Brittonia 33: 233-245.

Morrone, J. J. 2001. Biogeografía de América Latina y el Caribe. vol. 3. M \& T - Manuales \& Tesis SEA: Zaragoza. 148 pp.

Mort, M. E.; Archibald, J. K.; Randle, C. P.; Levsen, N. D.; O’Leary, T. R; Katarina, T.; wiegand, C. M. \& Crawford, D. J. 2007. Inferring phylogeny at low taxonomic levels: utility of rapidly evolving cpDNA and nuclear ITS loci. American Journal of Botany 94 (2): 173 183.

Nees, C. G. D. 1836. Systema Laurinarum. 8a ed, Cum Magna, Berlin Veit. 720 p.

Niedenzu, F. 1890. Malpighiaceae. Pp. 42-74. In: Engler, A. \& Prantl, K. (eds.). Die Natürlichen Pflanzenfamilien nebst ihren Gattungen und wichtigeren Arten, insbesondere den Nutzpflanzen, unter Mitwirkung zahlreicher hervorragender Fachgelehrten begründet. 4-5. Leipzig: Verlag von Wilhelm Engelmann.

Nylander, J. A. A. 2005. MrModeltest. v 2. Program distributed by the author. Uppsala: Evolutionary Biology Centre - Uppsala University.

Occhioni, P. 1967. Herbário da Faculdade Nacional de Farmácia da Universidade do Brasil / Catálogo do Herbário da Faculdade Nacional de Farmácia. Anais da Faculdade Nacional de Farmácia 7: 93-222.

Page, R. D. M. 1996. TREEVIEW: An application to display phylogenetic trees on personal computers. Computer Applications in the Biosciences 12: 357-358. 
Pax, F. 1889. Lauraceae. Pp. 106-126. In: Engler, A. \& Prantl, K. (eds.). Die Natürlichen Pflanzenfamilien nebst ihren Gattungen und wichtigeren Arten, insbesondere den Nutzpflanzen, unter Mitwirkung zahlreicher hervorragender Fachgelehrten begründet. 2 . Leipzig: Verlag von Wilhelm Engelmann.

Pax, F. 1897. Lauraceae. Pp. 174. In: Engler, A. \& Prantl, K. (eds.). Die Natürlichen Pflanzenfamilien nebst ihren Gattungen und wichtigeren Arten, insbesondere den Nutzpflanzen, unter Mitwirkung zahlreicher hervorragender Fachgelehrten begründet. 2-4. Leipzig: Verlag von Wilhelm Engelmann.

Pedralli, G. A. 1984. Família Lauraceae no Rio Grande do Sul, Brasil: Gênero Aiouea Aubl. Iheringia 32: 15-21,

Pedralli, G. A. 1986. A Família Lauraceae Lindley no Rio Grande do Sul, Brasil: Gênero Nectandra Rol. ex Rottb. Iheringia 35: 133-149.

Pedralli, G. A. 1987. Lauráceas: Nectandra - Flora Ilustrada Catarinense. Itajaí: CETEM. 93p.

Philippi, R. A. 1860. Florula Atacamensis seu enumeration plantarum quas in itinere per desertum Atacamense 21: 1-236.

Prance, G. T. 1979. The taxonomy and phytogeography of Chrysobalanaceae of the Atlantic coastal forest of Brazil. Revista Brasileira de Botanica 2: 19-39.

Quinet, A. \& Andreata, R. H. P.2002. Lauraceae Jussieu na Reserva Ecológica de Macaé de Cima, Município de Nova Friburgo, RJ, Brasil. Rodriguésia 53: 59-121.

Quinet, A. 2005. Sinopse taxonômica da família Lauraceae no Estado do Rio de Janeiro, Brasil. Acta Botanica Brasilica 19: 563-572.

Quinet, A. 2009. Lauraceae. Pp. 303-307. In: Stehmann, J. R.; Forzza, R. C.; Salino, A.; Sobral, M.; da Costa, D. P. \& Kamino, L. H. Y. (org.). Plantas da Floresta Atlântiva. Rio de Janeiro: Jardim Botânico do Rio de Janeiro. 
Quinet, A.; Baitello, J. B. \& Moraes, P., R., L. 2010. Lauraceae. Pp. 1146-1159. In: Forzza, R. C.; Baumgratz, J. F. A.; Bicudo, C. E. M., Carvalho Jr., A. A.; Costa, A., Costa, D. P.; Hopkins, M.; Leitman, P. M.; Lohmann, L. G.; Maia, L. C.; Martinelli, G.; Menezes, M.; Morim, M. P.; Coelho, M. A. N.; Peixoto, A. L.; Pirani, J. R.; Prado, J.; Queiroz, L. P.;

Souza, V. C.; Stehmann, J. R.; Sylvestre, L. S.; Walter, B. M. T. \& Zappi, D (org.). Catálogo de plantas e fungos do Brasil. v 2. Rio de Janeiro: Andrea Jakobsson Estúdio/ Instituto de Pesquisas Jardim Botânico do Rio de Janeiro.

Radford, A. E.; Dickison, W. C.; Massey, J. R. \& Bell, C. R. 1974. Vascular plant systematics. New York: Harper \& Row.

Ratter, J. A.; Bridgewater, S. \& Ribeiro, J. F. 2003. Analysis of the floristic composition of the Brazilian Cerrado Vegetation III: Comparision of the woody vegetation of 376 areas. Edinburgh Journal of Botany 60 (1): 57-109.

Record, S. J. \& Hess, R. W. 1942. American timbers of the family Lauraceae. Tropical Woods 69: 7-33.

Rehder, A., Weatherby, C. A., Mansfeld, R. \& Green, M. L. 1935. Conservation of later generic homonyms. Bulletin of Miscellaneous Information 6, 7, 8 \& 9: 341-544.

Renner, S. S. 1999. Circumscription and phylogeny of the Laurales: evidence from molecular and morphological data. American Journal of Botany 86:1301-1315.

Ribeiro, J. E. L. S.; Hopkins, M. J. G.; Vicentini, A.; Sothers, C. A.; Costa, M. A. S.; Brito, J. M.; Solza, M. A.; Martins, L. H. P.; Lohmann, L. G.; Assunção, P. A. C. L.; Pereira, E. C.; Silva, C. F.; Mesquita, M. R. \& Procópio, L. C. 1999. Flora da Reserva Ducke: guia de identificação das plantas vasculares de uma floresta de terra-firme na Amazônia central. Manaus: INPA. 816 p.

Richter, H. G. 1981. Anatomie des sekundären Xylems und der Rinde der Lauraceae. Sonderbd. Naturwiss. Vereins, Hamburg 5:1-148. 
Rizzini, C. T. 1967. Delimitação, caraterização e relações da flora silvestre hileana. Atas do Simpósio sobre a Biota Amazônica 4: 13-36.

Rizzini, C. T. 1978. Árvores e madeiras úteis do Brasil: manual de dendrologia brasileira. Editora Edgard Blücher LTDA.

Rodrigues, W. A. 1961. Aspectos fitossociológicos das caatingas do Rio Negro. Boletim do Museu Paraense Emílio Goeldi 15: 1-41.

Rohwer, J. G. 1986. Prodromus einer Monographie der Gattung Ocotea Aubl. (Lauraceae), sensu lato. Mitteilungen aus dem Institut fur Allgemeine Botanik Hamburg 20. 278p.

Rohwer, J. G. 1993a. Lauraceae. Pp. 336-391. In: Kubitzki, K.; Rohwer J. G. \& Bittrich, V. (eds). The families and genera of vascular plants. v 2. Magnoliid, Hamameliid and Caryophyliid families. Berlin: Springer-Verlag.

Rohwer, J. G. 1993b. Lauraceae: Nectandra. Flora Neotropica 60: 1-332.

Rohwer, J. G. 2000. Toward a phylogenetic classification of the Lauraceae: evidence from matK sequences. Systematic Botany 25 (1): 60-71

Rohwer, J.G. \& Kubitzki, K. 1985. Entwicklungslinien im Ocotea-Komplex (Lauraceae). Botanische Jahrbücher Systematic 107: 129-135.

Rohwer, J. G.; Li, J.; Rudolph, B.; Schmidt, S. A.; van der Werff, H. \& Li, H. 2009. Is Persea (Lauraceae) monophyletic? Evidence from nuclear ribosomal ITS sequences. Taxon 58 (4): $1153-1167$.

Rohwer, J. G.; Richter, H. G. \& van der Werff, H. 1991. Two new genera of neotropical Lauraceae and critical remarks on the generic delimitation. Annals of the Missouri Botanical Garden 78: 388-400.

Rohwer, J. G. \& Rudolph, B. 2005. Jumping genera: the phylogenetic positions of Cassytha, Hipodaphnis and Neocinnamomum (Lauraceae) based on different analyses of trnK intron sequences. Annals of the Missouri Botanical Garden 92: 153-178. 
Ronquist, F. \& Huelsenbeck, J. P. 2001. MrBayes 3: Bayesian phylogenetic inference under mixed models. Bioinformatics 19: 1572-1574.

Sampaio, A. J. 1917. Lauraceas de Matto-Grosso e duas novas espécies da Amazônia. Comissão de Linhas Telegráficas Estratégicas de Matto-Grosso ao Amazonas 56 (5): 13-15.

Sampaio, A. J. 1928. Silvia duckei A. Samp. n. comb. Boletim do Museu Nacional de Rio de Janeiro 4: 39-41.

Sanaiotti, T.; Bridgewater, S. \& Ratter, S. A. 1997. A floristic study of the savanna vegetation of the state of Amapá, Brazil, and suggestions for ITS conservation. Boletim do Museu Paraense Emílio Goeldi, Série Botânica 13 (1): 3-29.

Simmons, M. P. \& Ochoterena, H. 2000. Gaps as characters in sequence-based phylogenetic analyses. Systematic Biology 49: 369-381.

Soltis, D. E.; Smith, S. A.; Cellinese, N.; Wurdack, K. J.; Tank, D. C.; Brockington, S. F.; Refulio-Rodriguez, N. F. Walker, J. B.; Moore, M. J.; Carlsward, B. S.; Bell, C. D.; Latvis, M.; Crawley, S.; Black, C.; Diouf, D.; Xi, Z.; Rushworth, C. A.; Gitzendanner, M. A.; Sytsma, K. J.; Qiu, Y.; Hilu, K. W.; Davis, C. C.; Sanderson, M. J.; Beaman, R. S.; Olmstead, R. G.; Judd, W. S.; Donoghue, M. J. \& Soltis, P. S. 2011. Angiosperm Phylogeny: 17 genes, 640 taxa. American Journal of Botany 98 (4): 704-730.

Souza, V. C. \& Lorenzi, H. 2008. Botânica Sistemática: guia ilustrado para identificação das famílias de Fanerógamas nativas e exóticas do Brasil, baseado em APG II. $2^{\mathrm{a}}$ ed. Nova Odessa: Editora Plantarum.

Stafleu, F. A. \& Cowan, R. S. 1976. Taxonomic literature: a selective guide to botanical publications and collections with dates, commentaries and types. v $1,2^{\mathrm{a}}$ ed. Utrecht.

Stafleu, F. A. \& Cowan, R. S. 1979. Taxonomic literature: a selective guide to botanical publications and collections with dates, commentaries and types. $\mathrm{v} 2,2^{\mathrm{a}}$ ed. Utrecht. 
Stafleu, F. A. \& Cowan, R. S. 1981. Taxonomic literature: a selective guide to botanical publications and collections with dates, commentaries and types. $v 3,2^{\mathrm{a}}$ ed. Utrecht.

Stafleu, F. A. \& Cowan, R. S. 1983. Taxonomic literature: a selective guide to botanical publications and collections with dates, commentaries and types. $\mathrm{v} 4,2^{\mathrm{a}}$ ed. Utrecht.

Stafleu, F. A. \& Cowan, R. S. 1985. Taxonomic literature: a selective guide to botanical publications and collections with dates, commentaries and types. $v 5,2^{\mathrm{a}}$ ed. Utrecht.

Stafleu, F. A. \& Cowan, R. S. 1986. Taxonomic literature: a selective guide to botanical publications and collections with dates, commentaries and types. $v 6,2^{\mathrm{a}}$ ed. Utrecht.

Swofford, D. L. 2002. PAUP 4.0: Phylogenetic Analysis Using Parsimony. Sunderland, Massachusets, USA: Sinauer Associates.

Tate, J. A. \& Simpson, U. T. 2003. Paraphyly of Tarasa (Malvaceae) and diverse origin of the polyploidy species. Systematic Botany 28: 729-737.

Taubert, P. H. W. 1892. Revisio generum plantarum vascularium omnium atque cellularium multarum secundum leges nomenclaturae internationales cum enumeratione plantarum exoticarum in itinere mundi collectarum. Botanisches Centralblatt 50: 17-24.

Thomas, W. W.; Carvalho, A. M. V.; Amorin, A. M. A.; Garrison, J. \& Arbeláez, A. L. 1998. Plant endemism in two forests in southern, Brazil. Biodiversity and Conservation 7: 311322.

Thomaz, L. D. \& Monteiro, R. 1997. Composição Florística da Mata Atlântica de encosta da Estação Biológica de Santa Lúcia, Município de Santa Teresa-ES. Boletim do Museu de Biologia Mello Leitão 7: 3-48.

Umberto-Quattrocchi, F. L. S. 2000. CRC world dictionary of plant names: common names, scientific names, eponyms, synonyms, and etymology. CRC Press Inc. 1172 p.

van der Werff, H. 1987. A Revision of Mezilaurus (Lauraceae). Annals of the Missouri Botanical Garden 74: 153-182. 
van der Werff, H. 1991. A key to the genera of Lauraceae in the new world. Annals of the Missouri Botanical Garden 78 (2): 377-387.

van der Werff, H. 1993. A Revision of the genus Pleurothyrium (Lauraceae). Annals of the Missouri Botanical Garden 80 (1): 39-118.

van der Werff, H. 1994. Novelties in neotropical Lauraceae. Novon 4 (1): 58-76

van der Werff, H. 1997. Sextonia, a new genus of Lauraceae from South America. Novon 7 (4): $436-439$.

van der Werff, H. 2003. New taxa of Lauraceae from South America. Novon 13 (3): 337-357.

van der Werff, H. \& Nishida, S. 2010. Yasunia (Lauraceae), a new genus with two species from Ecuador and Peru. Novon 20 (4): 493-502.

van der Werff, H. \& Richter, H. G. 1996. Toward an improved classification of Lauraceae. Annals of the Missouri Botanical Garden 83: 409-418.

Vattimo-Gil, I. de. 1956a. O gênero Ocotea Aubl. no sul do Brasil I. Espécies de Santa Catarina e do Paraná. Rodriguésia 18-19 (30-31): 265-350.

Vattimo-Gil, I. 1956b. Nota prévia sobre espécies de Ocotea. Arquivos do Serviço Florestal 10: $109-123$.

Vattimo-Gil, I. 1957. Lauraceae do Estado do Rio de Janeiro: parte I - espécies do Monte Sinai, Governador Portela. Arquivos do Jardim Botânico do Rio de Janeiro 15: 115-144.

Vattimo-Gil, I. 1958. Seis novas espécies brasileiras do gênero Ocotea. Arquivos do Serviço Florestal 10: 109-123.

Vattimo-Gil, I. 1959. Flora da Cidade do Rio de Janeiro (Lauraceae). Rodriguésia 21/22 (3334): $157-176$.

Vattimo-Gil, I. 1966a. Lauraceae do Estado da Guanabara. Rodriguésia 25 (37): 75-113.

Vattimo-Gil, I. 1966b. Notas sobre o gênero Cryptocarya R.Br. no Brasil (Lauraceae). Rodriguésia 25 (37): 219-231. 
Vattimo-Gil, I. 1976. Estudos sobre Ocotea Aubl., Phyllostemonodaphne Kosterm. e Licaria Aubl. (Lauraceae). Rodriguésia 28 (41): 121-127.

Vattimo-Gil, I. 1978a. Contribuição ao conhecimento da distribuição geográfica das Lauraceas I. Rodriguésia 29 (44): 269-306.

Vattimo-Gil, I. 1978b. Contribuição ao conhecimento da distribuição geográfica das Lauraceas II. Rodriguésia 30 (47): 83-103.

Vattimo-Gil, I. 1979a. Contribuição ao conhecimento da distribuição geográfica das Lauraceas III. Rodriguésia 31 (48): 7-57.

Vattimo-Gil, I. 1979b. Contribuição ao conhecimento da distribuição geográfica das Lauraceas IV. Rodriguésia 31 (49): 5-16.

Vattimo-Gil, I. 1979c. Contribuição ao conhecimento da distribuição geográfica das Lauraceas V. Novas localidades de ocorrência nos estados do Paraná e Rio Grande do Sul. Rodriguésia 31 (50): 135-152.

Vattimo-Gil, I. 1980a. Contribuição ao conhecimento da distribuição geográfica das Lauraceas VI. Rodriguésia 32: 9-32.

Vattimo-Gil, I. 1980b. Contribuição ao conhecimento da distribuição geográfica das Lauraceas VII. Rodriguésia 32 (54): 351-368.

Vellozo, J. M. C. 1829. Florae Fluminensis, seu Descriptionum Plantarum Praefectura Fluminensi Sponte Nascentium Liber Primus. Flumine Januario: Typographia Nationali. $352 \mathrm{p}$.

Vicentini, A.; van der Werff, H. \& Nicolau, S. 1999. Lauraceae. Pp. 150-179. In: Ribeiro, J. E. L. S.; Hopkins, M. J. G.; Vicentini, A.; Sothers, C. A.; Costa, M. A. S.; Brito, J. M.; Solza, M. A.; Martins, L. H. P.; Lohmann, L. G.; Assunção, P. A. C. L.; Pereira, E. C.; Silva, C. F. Mesquita, M. R.; Procópio, L. C. Flora da reserva Ducke: guia de identificação das plantas vasculares de uma floresta de terra-firme na Amazônia central. Manaus: INPA. 
von Mohl, H. \& von Schlechtendal, D. F. L. 1854. Allemão, Plantas novas do Brasil. Botanische Zeitung 12: 434-439.

Wang, Z.; Li, J.; Conran, J. G.; Li, H. 2010. Phylogeny of the Southeast Asian endemic genus Neocinnamomum H. Liu (Lauraceae). Plant Systematics and Evolution 290: 173-184.

Weberling, F. 1985a. Zur Infloreszenzmorphologie der Lauraceae. Botanische Jahrbücher für Systematik, Pflanzengeschichte und Pflanzengeographie 107 (1-4): 395-414.

Weberling, F. 1985b. Aspectos Modernos de la Morfologia de las Inflorescencias. Boletin de la Sociedad Argentina de Botanica 24 (1-2): 1-28.

Weberling, F. 1989. Morphology of flowers and inflorescences. Cambridge: Cambridge University Press: 405p.

Whitmore, T. C. \& Sidiyasa, K. 1986. Composition and structure of a lowland rain forest at Toraut, northern Sulawesi. Kew Bulletin 41: 747-756.

Wurdack, J. J. 1970. Erroneous data in Glaziou collections of Melastomataceae. Taxon 19 (6): 911-913. 
Lista de Coletores

Mezilaurus

Adair: s.n. (INPA 72817) (7); s.n. (INPA 72870) (7); s.n. (INPA 72856) (7). Albuquerque, J. M.: 3 (7). Alencar, L.: 55 (7). Allemão: s.n. (BM 1009292/G-DC 200445/NY 355948) (9). Aluísio, J.: 98 (4); 110 (7); s.n. (INPA 150956) (7). Alves, F. M.: 522 (13); 523 (7); 524 (4); 529 (2); 530 (2). Alves, F. M. \& Garcez, W.: 44 (15); 45 (15). Anderson, W. R.: 10003 (2). Araújo: 12 (2). Araújo, A. et al.: 507 (7). Araújo, C. M.: 100 (7). Arbocz, G. F.: 386 (2); 792 (15); 6476 (13); 6491 (8). Árbocz, G. F. et al.: 3244 (2); 3697 (2); 4768 (2). Argemiro: s.n. (IAN 147896) (7); s.n. (IAN 147950) (7). Assis, A. M. \& Faria, K. F. O.: 1024 (2). Assunção, P. A. C. L. et al.: 541 (4).

Balcazar, J. et al.: 1709 (7). Barbosa, M. (L. P. F.): 504 (2); 487 (2); 279 (2); 661 (2); 446 (2); 397 (2); 632 (2). Barreto, M.: 1481 (2); 1742 (2). Barbosa, T. D. M. \& Alves, F. M.: 1012 (5); 1013 (5). Bastos, H. M.: 341 (2). Benson, W.: s.n. (2). Berg, C. C. et al.: 616 (7). Bernacci, L. C. et al.: 3684 (2). Bernardi, L.: 16227 (7); s.n. (G 433756) (7); s.n. (G 447959) (11); s.n. (MBM 184371) (7). Berry, P. \& Chesney, L.: 2053 (7). Berry, P. E. \& Aymard, G.: 7197 (7); 7503 (11). Binot, M.: 23 (9). Black, G. A.: 47-930 (7); 47-1030 (2); 47-1089 (7); $48-2397$ (7); 2397 (7). Blanco C.: 745 (2). Boudet-Fernandes, H. Q. \& Assis, A. M.: 3368 (2). Bridgewater, S. et al.: 103 (2). Burchell: 6758 (2). B. W.: 2398 (7); 3088 (7); 3829 (7); 4790 (7).

Campbell, D.: 342 (2); 828 (2); 853 (2); 886 (2). Campbell, D. G. et al.: 8816 (12). Castillo, A.: 40 (11). Cavalcante, P.: 2717 (13). Chagas, J.: s.n. (INPA 1215/MG 21108) (13). Cid, C. A. et al.: 4453 (2); 10376 (4). Clark, H. L. \& Maquirino, P.: 7357 (11); 7784 (11); 8091 (11). Coêlho, D.: 613 (13); s.n. (13). Coelho, D.: s.n. (INPA 42213) (4). Coelho, D. F.: s.n. (13). Coelho, D. et al.: s.n. (INPA 81943) (7); s.n. (13). Coelho, L.: 1873 (7). Coelho, L. \& Coelho, D.: s.n. (INPA 21164) (4); s.n. (INPA 21173) (7). Collella, M. et al.: 1557 (11). Cordeiro, M. R. et al.: 1435 (7); 1489 (7); 1497 (7); 1566 (7); 1599 (7). Costa, J. S.: 110 (15). Costa, R. C. M.: 323 (2).

da Cunha, N. M. L. et al.: 226A (7). da Luz, A. A.: 56 (2); 504 (2). Daly , D. C. et al.: 7080 (12). da Silva, A. S. L. et al.: 892 (7); 1830 (7). Defler, S.: 219 (6); 220 (6). de Lima, H. C. et al.: 5861 (9). Diaz, M.: 107-A (11); 166-A (7). Didi: s.n. (IAN 147964) (7). Dominguez, 224 
R. \& Polanco, H.: 729 (7). dos Santos, T. S.: 468 (13). Ducke, A.: 55 (3); 233 (13); 239 (13); 681 (7); 1336 (2); s.n. (RB 17539/U 1072) (2); s.n. (R 2542/RB 17540/MG 16032/MO 5180293/G s.n) (2); s.n. (INPA 15323/INPA 15327/RB 17538/U 1071) (2); s.n. (RB 17537/K s.n./P s.n./U 63401/G s.n.) (7); s.n. (RB 17537/K s.n./P s.n./U 63401/G s.n.) (7); s.n. (RB 19975 / U 1021) (7); s.n. (MG 16973) (7); s.n. (MG 7986) (7); s.n. (RB 19976 /INPA 15320/K s.n./U 1022) (7); s.n. (RB 11049/MG 17078/R 5209/U 63400/P s.n./BM s.n./G s.n) (7); s.n. (RB 19974/U 1093/INPA 15335/MO 5180294) (12); s.n. (INPA 15365) (13); s.n. (INPA 15321) (13); s.n. (RB 23964/K s.n./P s.n. /G s.n.) (13); s.n. (RB 25042/P s.n./U 36701/K. s.n.) (13). Duque, A. et al.: 856 (7).

Elias J. \& Aloísio: 461 (7). Erly: 119 (2); 0941705 (7); 1171706 (7); 1191707 (7); 1471709 (7); $1741711(7) ; 1901710(7)$.

Feitosa, R. N. S.: 16 (7); 73 (7); 75 (7). Ferreira, C. A. C. \& Ramos, J. F.: 12620 (7). Ferreira, C. A. C. et al.: 8772 (12). Ferreira, M. C. \& Jost, T.: 885 (10). Filho, H. \& Silva L. M.: 28 (7); 65 (7). Flores \& Tello: 6 (7); Forest Departament of British Guiana Field: 105/2704 (14); 205/2196 (2); 220/2956 (14). Franke, I. L. et al.: 35 (7). Freitas, J. L.: 79 (2). Froés, R. L.: 22878 (13); 25399 (13); 26565 (7); 28761 (1); 28898 (7); 30339 (2); 30870 (2); 30976 (2). Froés, R. L. \& Addison, G.: 29101 (7). Froés, R. L. \& Black, G. A.: 27453 (2). Froés, R. L. \& Filho, J. B.: 29546 (7);

Gentry, A. \& Stein, B.: 46836 (11). Gentry, A. et al.: 41945 (7); 46116 (12).Glaziou, M.: 12120 (9); 12124 (9); 12125 (9); 11470 (9); 11473 (9); s.n. (P s.n./BM s.n) (9); s.n. (K s.n./P s.n.) (9). Goldenberg, R.: 434 (2). Gomes, M. \& Damião, C.: 1528 (12); 1622 (12); 1827 (12); 1834 (12); 1897 (12); 1910 (12). Gomes, M. et al.: 566 (12); 772 (12); 792 (12); 847 (12); 888 (12); 927 (12); 1558 (12); 1872 (12). Gomes, M. J. G. \& Mota, C. D. A.: 1722 (12). Guerra, F.: 3 (2). Guimarães, J. G.: 97 (2).

Haroldo: s.n. (INPA 57764) (7); Hartshorn, G. \& Quijano, J.: 2945 (7); 2975 (7). Hartshorn, G. et al.: 2691 (7); 2920 (7). Herb. de J. Saldanha: 5493 (9). Hunt, D. R. \& Ramos, J. F.: $6082(2)$.

Inspectoria Florestal: 113 (9);

Jaramillo, N. et al.: 502 (7). Jardim, A.: 587 (7). Jesus, N. G.: 1868 (10). Jesus, N. G. et al.: $1622(10)$.

Krukoff, B. A.: 5221 (7). 5317 (7); 8711 (4). Kubitzki, K. et al.: 74-17 (7); 79-192 (7); 79-237 (7). Kuhlmann, J. A.: s.n. (RB 77229) (2). Kuhlmann, J. G.: 136 (9); 588a (2); 1782 (7); 225 
1925 (7); 1976 (7); 1977 (2); 1978 (2); s.n. (RB 3377/K s.n./P s.n./G s.n.) (2). Kurz, H.: B 1 (4); B 24 (4); B 31 (4).

Liesner, R. \& Hall, J.: 3444 (7). Lima, A.: 58-3027 (2); Lima, J. et al.: 1015 (7); Lisboa, P. et al.: 1713 (7); 3071 (2). Loneto, Z. S. \& Dimas: 2399 (2). Lorenzi, H.: 1459 (15); 1467 (15); 1526 (2); s.n. (SPSF 17364) (2); s.n. (SPSF 17365) (15); s.n. (SPSF 17368) (2). Lourival: s.n. (INPA 57763) (4); s.n. (INPA 57745) (7). Loureiro, A. et al.: s.n. (INPA 38012) (7). L. P. F.: 261 (7); 275 (7); 283 (7); 315 (7); 350 (7); 467 (2); 640 (2); 662 (2).

Macedo, M. et al.: s.n. (INPA 197054) (7). Macedo, M. \& Assunção, S.: 1758 (15). Maciel, U. N. \& Rosário, C. S.: 550 (7); 1703 (7). Maciel, U. N. et al.: 600 (7); 1399 (7). Mackenzie, C. A. et al.: s.n. (INPA/WWF 2206.2089) (4); s.n. (INPA/WWF 2206.1745) (11); Mackenzie, C. A. et al.: s.n. (MO 5762693) (11). Magnago et al.: s.n. (INPA 58278/MG 57464) (4). Maguire, B. et al.: 41698 (11); 56549 (7). Maia, L. A. et al.: 55 (7). Mantovani, W. \& Rocha, D. M. S.: 12746 (7); Marimon, B. S.: 507 (2); 582 (2). Mei 45: (7). Mélinon, M.: 46 (7); 613 (7); 619 (7); s.n. (P s.n.) (7); s.n. (P s.n.) (7); s.n. (P s.n.) (7). Mello, F.: s.n. (INPA 55259) (4); s.n. (INPA 60171) (7). Mello, F. \& Ramos, J.: s.n. (INPA 57753) (7); s.n. (INPA 57755) (7); s.n. (INPA 57779) (7). Mello, F. \& Ribamar, J.: 21 (7). Meneces, E.: 601 (7); 605 (12); 626 (7). M. G. : 1707 (12). M. G. \& Mota, C. D. A.: 1676 (12). M. G. J. G. \& Mota, C. D. A. 1329: (12). M. G. et al.: 1089 (12). M. G. et al.: 1308 (12). Milliken, W. \& Miller, R.: 571 (2). Miranda, S.: 899 (12). Monteiro, O. P.: 1302 (7). Moraes, E. C. C. et al.: 112 (2). Morellato-Fonzar, L. P. C. \& Rosa, N.: 18382 (7). Mori, S. et al.: 15932 (7); 16482 (2); 20458 (7). Mota, C. D. A.: 734 (7).

Nascimento, J. R.: 14 (2). Nascimento, S. M.: 9 (7). Nunes, G. M.: 113 (9).

Oliveira, A. A. et al.: 1060 (7); 1084 (7); 1287 (7); 1289 (7); 1349 (4); 1488 (7); 1498 (7); 1604 (7); 1901 (7); 315 (7); 362 (7). Oliveira, C. A. L. et al.: 1262 (9). Oliveira, E.: 4538 (2); 4673 (2); 4749 (2); 4804 (7); 4818 (7); 4824 (7); 4847 (7). Oliveira-Filho, A. T.: 53 (2); 08 (2). Oliveira, J. E.: 356 (2).

Palacios, P. A. et al.: 538 (7). Pereira, M. J. R. / INPA/WWF 2303.19995: (7). Pereira, M. J. R. et al. / INPA/WWF 1301.3258: (11). Pires, J. M.: 7368 (2). Pires, J. M. \& Belem, R. P.: 12867 (2); 13068 (2); Pires, J. M. \& Black, G. A.: 1147 (7). Pires, J. M. et al.: 14385 (7). Plowman, T. et al.: 9678 (7). Pott, A.: 2477 (15); 5582 (15); 14138 (2). Pohl: 1463 (1932d) (2). Popovkin, A.: 594 (10). Prance, G. T. et al.: 12450 (7); 16042 (11); 20509 (7). Projeto 
Dinâmica Biológica de Fragmentos Florestais - PDBFF: árvore 3587 (11). Pruski, J. et al.: $3402(2)$.

Rabelo, B. V. et al.: 2777 (2). Raimundo: s.n. (IAN 147922) (7). Ramalho, A. T.: 7 (9); 1 (9). Ramos, J. F.: 1876 (7). Ratter, J. A. et al.: 805 (2); 912 (2); 1293 (2); 7115 (2); 7454 (2); 7480 (15); 7517 (15); 7637V (15); 7709V (2); 7957V (2). Ratter, J. A. \& J. Lemos: 572 (2). Ratter, J. A. \& Sanaiotti, T. M.: 6911 (2). Reis, L. Q.: s.n. (INPA 57777) (4); s.n. (INPA 57766) (7). Resende, U. M.: 1032 (15). Revilla, J.: 106 (11); 1226 (7). Ribeiro, B. G. S.: 1450 (2). Ribeiro, J. E. L. S. \& Assunção, P. A. C. L.: 1320 (7). Ribeiro, R. D. et al.: 1205 (7). Ribeiro, T. et al.: 85 (10); 329 (10); 330 (10). Riera, B. \& Sabatier, D.: 1315 (7). Rizzo, J. A.: 4069 (2); 4220 (2); 11361 (2). Rizzo, J. A. et al.: 11293 (2); 11429 (2); 11254 (2); 11162 (2); 11119 (2); 11361 (2); 11031 (2). Roa, A. T.: 424 (7). Roberto: s.n. (INPA 57750) (7). Rodrigues, J. B.: 11 (2); 129 (2); s.n. (R 31126) (7). Rodrigues, W.: 7981 (13); 7982 (13); 8729 (13); 8746 (13); 9150 (4); 9986 (13); 9994 (13). Rodrigues, W. A.: 10336 (2); s.n. (13). Rodrigues, W. \& Loureiro, A.: 7039 (4). Rodrigues, W. \& Coelho, D.: 6943 (4); 7555 (7); 7873 (4); 8352 (7); 10295 (7). Rodrigues, W. \& Jaccoud, S. R.: 8884 (13). Rodrigues, W. \& Osmarino: 7902 (7); 7920 (7); 8119 (7); 8138 (7); 8203 (4). Rodrigues, W. \& Lima, J.: 3047 (13). Rodrigues, W. et al.: 11134 (13). Rosa, N. A.: 1209 (12). 1357 (7). Rosa, N. A. \& Santos, M. R.: 4291 (2). Rosário, C. S. et al.: 1024 (2).

Sabatier, D. \& Prevost, M. F.: 2607 (7); 3166 (7); 3929 (7). Sabatier, D. \& Riera, B.: 1729 (7). Salis, S. et al.: 1142 (15). Salviani, E. R. \& Lorenzi, H.: 5 (15). Santos, J. U. et al.: 743 (7); 746 (7); 775 (7). Santos, M. R.: 649 (7). Saraiva, R. \& Rego, I. F.: 305 (7). Schwacke (Glaziou, A. 19798): 7080 (2). Silva, M.: 2666 (7). Silva, M. F. \& Coêlho, L.: 25 (13). Silva, M. F. et al.: 720 (7). Silva, M. G.: 5499 (2); 6056 (7). Silva, M. G. \& Bahia, R.: 2909 (7). Silva, M. G. \& Rosário, C.: 4756 (7); 4772 (12); 5018 (2); 5860 (7). Silva, M. T. M.: 38 (2). Silva, M. \& Souza, R.: 2403 (2). Silva, M. et al.: 99 (13); 336 (7). Silva, N. T.: 996 (2); 1041 (7); 1845 (7); 1911 (2); 2306 (2); 2704 (7); 3190 (2); 3238 (7); 3278 (7); 5198 (7); 5243 (2). Smith, A. C.: 3208 (2). Sobrinho, F. A. \& da Silva, W.: 26 (9). Soler, A. J. G. \& Barbosa, E. F.: 214 (12). Souza, J. E. C.: 1272 (4). Souza, V. C. et al.: 17854 (2). Sperling, C. R.: 5699 (7). Sperling, C. R. et al.: 5614 (7); 5828 (7); 5948 (2). Spichiger, R. \& Loizeau, P.-A.: 4154 (11); 4155 (11); 4156 (11); 4157 (11); 4158 (11); 4159 (11); 4174 (7). Spruce, R.: 18 (7); 19 (7); 643 (7); 646 (7); 669 (7); 965 (7); 2323 (11); 2961 (7); s.n. (K s.n.) (7). Steyermark, J. A. \& Bunting, G.: 102781 (7). 
Thomaz, L. D.: s.n. (SPSF 18758) (5); 1299 (5); 1530 (5); 1570 (5); 1571 (5); 1572 (5); 1573

(5). Toledo, M. et al.: 2093 (7). Trigoso, J. R.: 620 (7). Turpin: s.n. (P s.n.) (7).

Ule, E.: 6055 (7); 7578 (2); 8835 (13).

Valencia, R. et al.: 67359 (7). van der Werff, H. et al.: 10263 (7); 19445 (7); 20031 (7). van Donselaar, J.: 2043 (7); 2906 (7); 3177 (7). Vasconcelos, S. T. et al.: 34 (15). Vásquez, R. \& Jaramillo, N.: 984 (11). Vásquez, R. \& Jaramillo, N.: 15759 (7). Vásquez, R. et al.: 24170 (7). Velloso, H.: 450 (9). Vicentini, A.: 1673 (7); 1685 (7). Vicentini, A. \& Assunção, P. A. C. L.: 593 (7). Vicentini, A. \& da Silva, C. F.: 421 (7). Vicentini, A. \& Pereira, E. C.: 992 (4). Vicentini, A. et al.: 654 (4); 1218 (4); 753 (13).

Weddel, M. A.: 2066 (2). Wilde, L.: 26 (4). Williams, L.: 15726 (7). Williams, L. \& Silva, N. T.: 18231 (2). Wilson-Browne, G. S. J.: 390 (2); 486 (2). Wurdack J. J. \& Guppy N. G. L. 91: (2).

Zent, S.: 886-19 (11).

s.c. s.n.: (MIRR 6386) (2); (INPA 150936) (7); (P s.n.) (7); (W s.n.) (7); (RB 148918) (9); (R 30942) (9); (BHCB 67571/R 30942) (9); (MO 3599467) (11); (SP 236696) (12).

\section{Clinostemon}

Alves, F. M.: 528. Anderson, A.B. \& Rosário, C.S.: 1453. Black \& Foster: 48-3415. Drees, E. M.: s.n. Ducke, A.: 1234; s.n. (U 1070/U 1069/RB 17583); (MG 16692); s.n. (R 61241/K s.n./MG 16538/US 1442483/P 128423/U 1088/INPA 11732). Flores \& Tello: 310 . Gély, A. \& Anderson, A.: 717. Graham J. G.: 2794. Krukoff, B. A.: 5870. Lorenzi, H.: 1774. Maciel, U. N. et al.: 2101. Mori, S. et al.: 16510. Oliveira, J. \& Nascimento, M. C.: 625. Oliveira, J. et al.: 78. Pipoly, J. J. et al.: 12230. Pires, J. M.: 1488. Rabelo, B. V. \& Cardoso, J.: 2715. Rabelo, B. V. et al.: 2632. Revilla, J. et al.: 4520. Tello: 1930. van der Werff, H.: 11852. van der Werff, H. et al.: 10227. Vásquez, R. \& Jaramillo, N.: 12231. Vásquez, R. et al.: 14372; 18724; 21642; 24115. 


\section{Índices de nomes populares}

ajomonto diamaro: 110 .

ajomonto horadihoro:110.

apisi-ie: 110 .

canela-amarela: 162.

canela-cajú: 70.

canela-roxa: 70.

canela-marmelada: 126.

canela-tapinhoã: 126 .

caneleira-amarela: 162 .

canella-marmellada: 70 .

canella-tapinhoam:70.

cedro-pardo: 110.

cedro-preto: 110 .

chancaca: 110.

chancaca-amarilla: 110.

chupon:70.

cumbuca: 70 .

cumbuquinha: 70 .

ita-iba:110.

ita-uba: 109, 110.

itaúba: 3, 8, 70, 84, 84, $109,126,140,147,152$,

152,200 e 201.

itaúba-abacate: 70, 84, 109,

147.

itaúba-amarela: 70, 109, 126, 152. itaúba-amarela-comum:

109.

itaúba-amarilla: 110.

itaúba-basina: 109.

itaúba-chichica: 152.

itaúba-colorada:110.

itaúba-da-campina:109.

itaúba-da-mata: 70.

itaúba-da-folha-miúda:

109.

itaúba-folha-miúda:109.

itaúba-grande: 109.

itaúba-negra: 147.

itaúba-penimá:109.

itaúba-peuma:109.

itaúba-piúna:109.

itaúba-pixuna:109.

itaúba-preta: 109.

itaubarana-pixacatinga:

109.

itaúba-roxa: 109.

itaúba-surubim: 109, 152.

itaúba-verdadeira: 109 ,

126.

itaúba-xumbo: 109

japiu-dlr: 110

kaneelhout: 110

kaneeri-pisi: kaneerju: 110

kjarie kjanarie: 110

lorê: 110

louro-abacate: 109

louro-apagão-verdadeiro:

134

louro-itaúba: 147 e 152

louro-itaúba-abacate: 84 e

152

mãe-de-itaúba: 70

palta-moena:

parature: 110 e 140

phara-ture: 140

paratute-blanco: 140

parature-negro: 110

paraturi: 110

rukut: 70

quariquara-amarela: 110

siruaballi tataroo: 110

taoub-brun: 110

taoub-jaune: 110

tapinhoã: 8, 70, 126, 127,

162 e 201

tapinhoã-amarelo: 126

tapinhoam:126

tapinhoam-amarelo:126

tapinhoam-olho-de-sapo:

126 
tapinuã: 126

tauwa-yet: 70

tripa-de-perro: 70

ubá: 84 


\section{Índices de nomes científicos}

As espécies de Clinostemon e Mezilaurus, aceitas no presente trabalho, são colocadas em negrito e itálico, ao passo que os sinônimos e as combinações dos nomes aceitos, indicados somente em itálico. O número da página em negrito referente-se ao da descrição da espécie, enquanto o asterisco $(*)$ indica página com ilustração ou mapa.

\section{Acrodiclidium:}

anacardioides: 12, 98, 114, 115.

itauba: 12, 98, 116.

itauba var. amarella: 98, 114, 115, 116.

mahuba: 9, 13, 49, 50, 166, 173.

oppositifolium: 12.

sprucei: $12,137$.

Aionea: 10, 51, 53, 54.

Anacardiaceae: 180.

Anacardium: 180.

Anaueria: 1, 2, 6, 9, 10, 11, 16, 20, 35, 36,

37, 38, 39, 204.

brasiliensis: 16, 20.

Aniba: 3.

rosaeodora: 3 .

Anibineae: 9.

Appolonias: 9.

Appollonieae: 9.

Beilschmiedia: 6, 9, 16, 37, 92.

robusta: 16, 20.

Beilschmiediineae: 9.
Brachyteles hipoxanthus: 70.

Caryodaphnopsis: 16, 35, 38.

laotica: 16, 20.

tonkinensis: 16, 20.

Cassytha: 3, 4, 6.

Cassythoideae: 4.

Chlorocardium: 1, 2, 6, 10, 11, 16, 35, 36, 37, 38, 39, 204.

rodiei: $16,20$.

venenosum: 16, 20.

Cinnamomeae: 5,9 .

Cinnamomum: 3. zeylanicum: 3.

\section{Clinostemon:}

maguireanum: 156, 176, 205.

mahuba:13, 18, 24, 50, 51, 60, 158, $165,166,169,170,171,172,174 *$, $175^{*}, 182,184,195,196,199$.

Combretaceae: 180 .

Cryptocarya: 7, 92.

saligna: $16,18$. 
Cryptocaryeae: 5, 8, 16.

Dahaasia: 9

Endiandra 8, 9, 12, 13, 14.

itauba: 98.

navalium: 124.

Endlicheria: 6.

Escobedia: 12.

Hexapora: 9.

Lauraceae: $3,4,5,6,7,8,9,10,12,14,16$, $27,28,35,36,38,41,48,50,51,54$, $55,56,73,74,92,162,166,176$, 191, 192.

Lauroideae: 4, 12.

Laurus nobilis: 3.

Licaria: 8, 9, 10, 13, 14, 16, 20, 49, 50, 51, 53,54 .

mahuba: 166.

maguireana: 13, 156.

triandra: 16, 20.

Malpighiaceae: 13, 14.

Mezia:

anacardioides: 98.

crassiramea: 63.

itauba: 98.

navalium: 124

sprucei: 137.

\section{Mezilaurus:}

anacardioides: 12, 98, 114, 115.

caatingae: $56,58,59,60^{*}, 61^{*}, 79,111$, 180, 184, 187, 191, 195, 196, 199, 201.

campaucola: 99, 112, 113, 114. crassiramea: $13,18,24,43,44,46,56$, $62^{*}, 63,70,71,72,76^{*}, 91,119,121$, $128,132,134,163,176,182,184,185$, 187, 191, 195, 196, 198, 199, 200, 201. decurrens: $13,58,60,62 *, 77,78,80 *$. duckei: 18, 24, 42, 43, 44, 56, 71, 81, $83,84,85,87^{*}, 88^{*}, 158,179,171,176$, 180, 182, 184, 185, 187, 191, 195, 196, 199.

glabriantha: 18, 24, 43, 44, 46, 56, 88*, 89, 90, 91, 92, 93*, 111, 127, 135, 185, 191, 196, 198, 199, 200, 201.

glaucophylla: 13, 165.

introrsa: 57, 88*, 93*, 94, 97*, 111, 176, 185, 191, 195, 196, 199, 201.

itauba: $3,13,18,24,43,44,57,58,60$, 71, 79, 89, 92, 94, 96, 98, 109, 110, $117^{*}, 118^{*}, 141,152,153,163,176$, 184, 185, 191, 196, 198, 200, 201.

lindaviana: 13, 63, 71, 72, 74.

maguireana: 137.

mahuba: 1, 2, 20, 40, 42, 48, 49, 50, $165,166$.

manausensis: 137, 141.

matogrossensis: 165.

micrantha: 99, 112.

microphylla: 18, 43, 44, 47, 57, 71, 119 , $120,121,122 *, 123 *, 180,182,184$, 185, 191, 196, 198, 199, 200, 201.

navalium: 13, 18, 43, 44, 46, 55, 56, 91 , $113,123^{*}, 124,126,127,128,129,130$, 
$131^{*}, 135,176,184,185,191,196,198$, 199, 200, 201.

opaca: 99, 112, 113.

oppositifolia: 165.

palcazuensis: 99, 112, 113.

pyriflora: 81,85 .

quadrilocellata: 13, 165.

revolutifolia: 57, 91, 123*, 127, 132,

133, 134, 135, 136*, 152, 182, 185, 191, 196, 198, 199, 200, 201.

sprucei: 13, 57, 137, 140, 141, 142*, 143*, 182, 185, 191, 192, 196, 201.

subcordata: $13,57,96,143 *$, 144, 146, 147, 148*, 182, 184, 185, 191, 192, 195, 196, 201.

synandra: $13,18,24,43,44,46,47,57$, 71, 96, 111, 112, 127, 135, 149, 154*, $155^{*}, 151,152,153,180,184,187,191$, 192, 196, 199, 201.

thoroflora: 43, 44, 56, 155*, 156, 157, 158, 159*, 170, 171, 176, 182, 184, 185, 191, 192, 195, 196, 199, 201.

triunca:

vanderwerffii: $18,24,43,44,46,57$, 71, 121, 155*, 160, 162, 163, 164*, 184, 185, 191, 196, 198, 199, 200, 201.

wurdackiana: 63, 72.

Misanteca: 8, 9, 12, 14.

anacardioides: 98.

crassiramea: 63.

duckei: 63, 72, 74.

maguireana: 156. mahuba: 166.

Mocinnodaphne: 10, 51, 53,

Myrtaceae: 110.

Nectandra: 37, 41.

Neosilvia: 13, 55.

Ocotea: 37, 41, 92. odorifera: $3,16,20$

porosa: 3.

Oreodaphne crassiramea: 12, 63, 73. hookeriana: 98, 114.

Paspalum: 116.

Pavedadaphne: 10.

Persea: 6, 7, 35, 38. americana: 3, 16, 20.

Perseeae: 9.

Perseeae-Lareae: 16.

Pleurothyrium cinereum: 16, 20.

Poaceae: 116.

Portulacaceae: 12, 14.

Potomeia:

Pouteria:

Rhanphastidae:

Rhanphastos:

Rhodostemonodaphne:

Salvertia convallariodora:

Sapotaceae: 180.

Sextonia: 1, 2, 6, 11, 16, 20, 24, 35, 36, 37, 38, 39, 40, 41, 47, 48, 49, 50, 51, 204 pubescens: 16, 20. rubra: 16, 18, 24.

Silvaea: 8, 12, 14, 55. navalium: 124. 
Silvia: 8, 9, 11, 13, 14, 55.

anacardioides: 98.

crassiramea: 63.

decurrens: 77, 79.

duckei: 63.

itauba: 98.

navalium: 11, 12, 124.

polyantha: 98, 114.

rondonii: 99, 114, 115.

sprucei: 137.

subcordata: 144.

synandra: 13, 149.

Terminalia: 180.

Umbellularia californica: 16, 20.

Yasunia: 10, 51, 53, 54.

sessilifolia: 10, 53.

Williamodendron: 1, 2, 6, 10, 11, 14, 16, 18,

$24,35,36,37,38,39,40,41,47,48,49,51$,

$54,92,204$

cinnamomeum: $16,18,24,92,165$.

glaucophyllum: 165.

quadrilocellatum:165.

spectabile: 165. 